\title{
O CONTROLE JUDICIAL DOS ATOS ADMINISTRATIVOS DISCRICIONÁRIOS E A JURISPRUDÊNCIA
}

Dissertação apresentada à

Faculdade de Direito da

Universidade de São Paulo USP - para a obtenção do título de Mestre em Direito Administrativo.

Orientador: Prof. Associado Dr. Edmir Netto de Araújo.

\section{Universidade de São Paulo \\ Faculdade de Direito \\ São Paulo \\ 2014}


Nome: Angiolucci, Maria de Lurdes Aparecida Trujillo

Título: O Controle dos Atos Administrativos Discricionários e a Jurisprudência

Dissertação apresentada à

Faculdade de Direito da Universidade de São Paulo USP - para a obtenção do título de Mestre em Direito Administrativo.

Aprovada em:

\section{Banca Examinadora}

Prof. Dr. Julgamento:

Prof. Dr. Julgamento:

Prof. Dr. Julgamento: Instituição: Assinatura: Instituição: Assinatura: Instituição: Assinatura: 
A Deus por minha fé, o que seria de mim sem ela!

À minha família, com amor e gratidão pela compreensão, carinho e apoio na elaboração deste trabalho. 


\section{AGRADECIMENTOS}

Ao Professor Dr. Edmir Netto de Araújo, pelo apoio, pela amizade, pela simplicidade e pela dedicação durante o processo de orientação;

À Universidade de São Paulo pela oportunidade de realização do Mestrado;

Aos demais Professores da Universidade com os quais tive a honra da rica convivência;

Aos professores Fernando Menezes de Almeida e Roger Stiefelmann Leal, que compuseram a banca de qualificação desta dissertação e que muito cooperaram para seu aperfeiçoamento;

Aos colegas da pós-graduação e, em especial, à Ana Maria Pedreira que sempre se colocou à disposição dos seus pares, não medindo esforços para atender a todos;

Muito obrigada! 


\section{RESUMO}

Angiolucci, Maria L. A. Trujillo. O controle judicial dos atos administrativos discricionários e a jurisprudência. 2014. Dissertação (Mestrado) - Faculdade de Direito, Universidade de São Paulo, São Paulo, 2014.

O presente trabalho de pesquisa tem por objetivo analisar algumas das inúmeras decisões do Supremo Tribunal Federal e do Superior Tribunal de Justiça, bem como do Tribunal de Justiça de São Paulo, em matéria de controle jurisdicional dos atos administrativos discricionários e verificar se é possível identificar mudança substancial nos limites desse controle. O trabalho foi dividido em duas partes, sendo a primeira constituída por uma pesquisa bibliográfica destinada, essencialmente, a situar o tema da discricionariedade administrativa, num enfoque conceitual e histórico. A segunda parte refere-se à pesquisa sobre o tema na jurisprudência do Supremo Tribunal Federal, Superior Tribunal de Justiça, Tribunal de Justiça de São Paulo e, ainda, no acórdão relativo à apelação cível $\mathrm{n}^{\circ}$. 1.422 do Tribunal de Justiça do Rio Grande do Norte, cuja relatoria ficou a cargo de Miguel Seabra Fagundes. Os atos administrativos discricionários, por muito tempo foram considerados insindicáveis pelo Poder Judiciário, ou seja, imunes à apreciação jurisdicional. Contudo, é possível identificar o surgimento de alguns parâmetros jurídicos que objetivaram restringir a atividade administrativa discricionária, inserindo-a, sob determinados aspectos, no âmbito da apreciação jurisdicional. $\mathrm{O}$ balizamento inicial restringiu-se à lei, permanecendo o mérito do ato administrativo intocado. Nesse processo de tentativa de contenção dos atos administrativos discricionários desenvolveram-se teorias de controle, como a teoria do desvio de poder e a teoria dos motivos determinantes. Cite-se, também, a teoria dos conceitos jurídicos indeterminados e, mais recentemente, a teoria da vinculação dos atos administrativos aos princípios constitucionais. O mérito do ato administrativo é o "espaço" que ainda suscita algumas controvérsias. A pesquisa jurisprudencial foi realizada, em sua maioria, diretamente nos sítios do Tribunal respectivo. Nota-se, ao analisar a jurisprudência, que há uma tendência no STF e no STJ em acolher a tese de uma apreciação mais ampla pelo Poder Judiciário, como foi o caso do Resp 429570/GO, cuja relatoria ficou a cargo da Ministra Eliana Calmon; se bem que é ainda, bastante comum, os acórdãos explicitarem que não cabe apreciação pelo judiciário sob o aspecto da conveniência e oportunidade do ato administrativo, ou seja, do mérito do ato.

Palavras chave: 1. Ato discricionário - controle - 2. Discricionariedade - controle - 3 . controle judicial dos atos administrativos - 4. controle jurisdicional dos atos administrativos -5 . Controle dos atos discricionários). 


\begin{abstract}
Angiolucci, Maria L. A. Trujillo. The judicial review of discretionary administrative acts and jurisprudence. 2014. Dissertação (Mestrado) - Faculdade de Direito, Universidade de São Paulo, São Paulo, 2014.

This research aims to examine some of the numerous decisions of the Supremo Tribunal Federal and Superior Tribunal de Justiça, as well as the Tribunal de Justiça de São Paulo, regarding judicial control of discretionary administrative acts and verify that is possible to identify substantial change in the limits of this control. The work was divided into two parts, the first consisting of a literature research aimed essentially to place the issue of administrative discretion, in a conceptual and historical focus. The second part refers to research on the topic in the jurisprudence of the Supremo Tribunal Federal, Superior Tribunal de Justiça, Tribunal de Justiça do Estado de São Paulo and also in the judgment on the civil appeal $n^{\circ} .1422$ of the Tribunal de Justiça do Rio Grande do Norte, whose rapporteur was entrusted to Miguel Seabra Fagundes. Discretionary administrative acts were long disregarded by the judiciary, in other words immune to judicial review. However, it is possible to identify the rise of some legal parameters that aimed to restrict the discretionary administrative activity by inserting it, in certain respects, within the scope of judicial review. The initial marking was restricted to the law, remaining the substance of the administrative act untouched. In this process to attempt to contain discretionary administrative acts were developed theories of control, as the deviation of power and the theory of determinants reasons. Is mentioned, too, the theory of indeterminate legal concepts and, more recently, the theory of binding administrative acts to constitutional principles. The merit of the administrative act is the "space" that still shows some controversies. The jurisprudential research was conducted, for the most part, directly on the websites of the respective Court. It is noted, when considering the case law, that there is a trend in the STF and STJ to welcome the idea of a wider appreciation by the judiciary, like was the case Resp 429570/GO, whose rapporteur was in the responsibility of the Minister Eliana Calmon, although it is still quite common, the judgments stating that it is not for consideration by the judiciary under the aspect of convenience and opportunity of the administrative act, in other words, the act of merit.
\end{abstract}

Keywords: 1. Discretionary act - control - 2. Discretionary - Control - 3. judicial review of administrative acts -4 . judicial review of administrative acts -5 . Control of discretionary acts. 


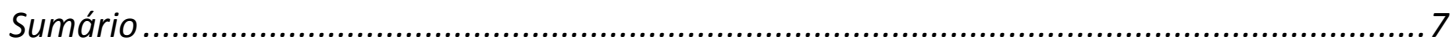

1. Introdução

Parte 1 - discricionariedade - generalidades..............................................................16

2. Evolução histórica da administração pública - discricionariedade - controle da administração ......................................................................................................................................................16

2.1. Primeira fase do Estado Moderno - Estado de Polícia......................................................16

2.2. Segunda fase do Estado moderno - Estado liberal de direito .......................................19

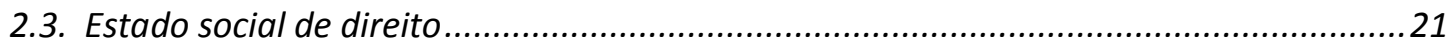

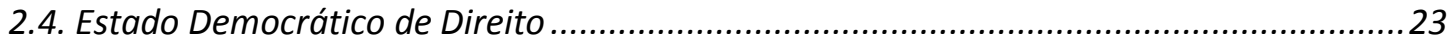

3. Discricionariedade - Considerações gerais ................................................................................25

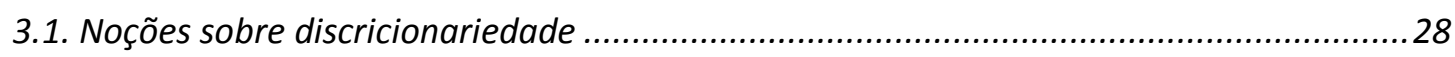

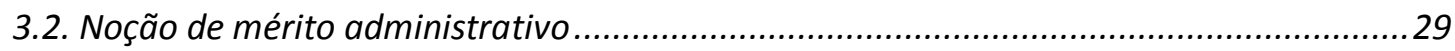

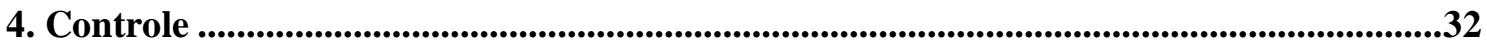

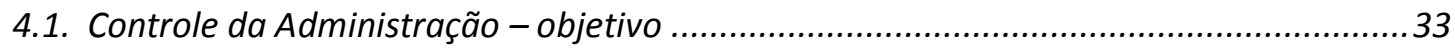

4.2. Controle Judicial da Administração - controle externo..................................................36

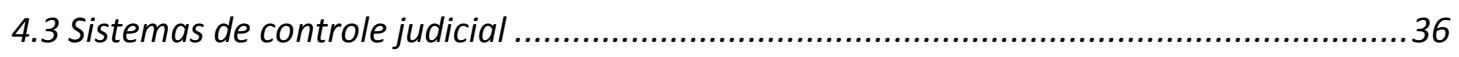

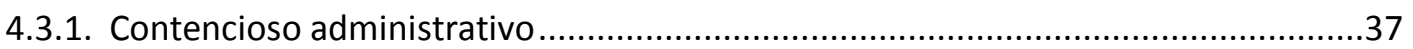

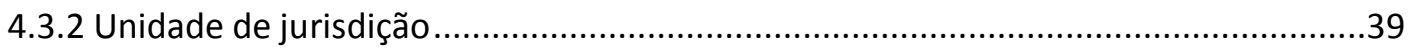

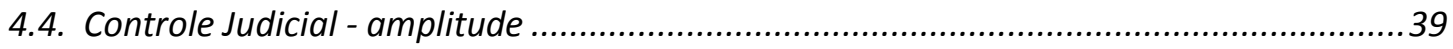

4.4.1. Controle sobre os requisitos vinculados - competência, forma e finalidade ...........41

4.5. Teoria do desvio de poder (dètournement de pouvoir)/desvio de finalidade...................43

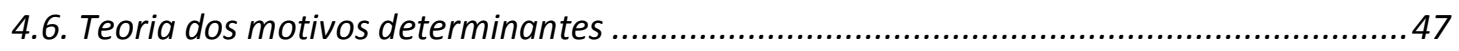

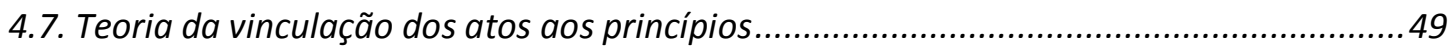

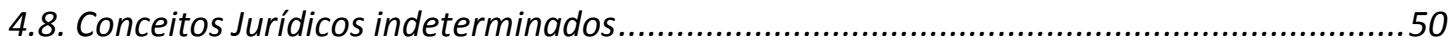

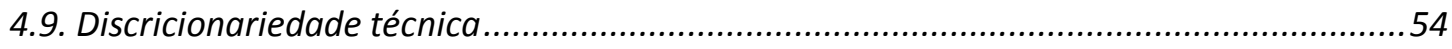

Parte 2 - O Controle dos Atos Administrativos Discricionários pelos Tribunais ..................58 
5.1.1. Considerações Iniciais. 59

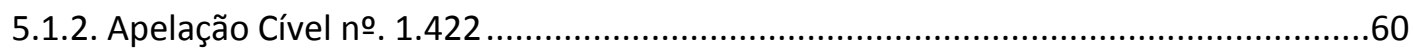

5.1.3. Competência discricionária da Administração e controle judicial ........................63

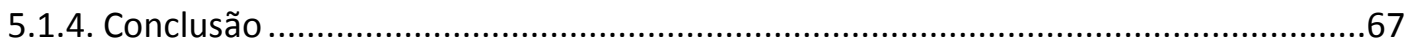

6. Supremo Tribunal Federal ...............................................................................................69

6.1. Ato discricionário praticado ao "tempo em que o Governo esteve investido de todos os poderes"

6.1.1. Agravo de Petição no 9.949 - São Paulo - 16/09/1941 - 2a. Turma ........................70

6.1.2. Agravo de Petição no. 12.210 - Distrito Federal - 28/5/1945 - 1a. Turma ..............71

6.1.3. Recurso Extraordinário no 19.720 - Distrito Federal - 17/6/1952 - 2a․ Turma.........72

6.1.4. Recurso Extraordinário - embargos- no 21.541 - Distrito Federal - 25/06/1954 - 1a.

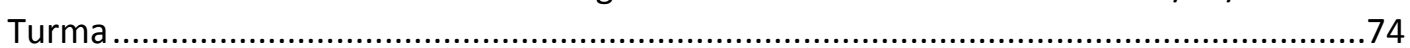

6.1.5. Mandado de Segurança $n$ o 18.671- Distrito Federal - 6/6/1973 - Tribunal Pleno....77

6.2. Ato administrativo relacionado à demissão, admissão, remoção, aposentadoria, reforma ou promoção de servidor público ........................................................................ 79

6.2.1. Mandado de Segurança no. 1.103 - Distrito Federal - 1ㅇ..12.1949- Pleno..............79

6.2.1. Embargos na apelação Cível no 7.307 - 20/12/1944 …...................................83

6.2.2. Recurso em Mandado de Segurança no. 7.320 - Rio Grande do Sul - 21/06/1960 -

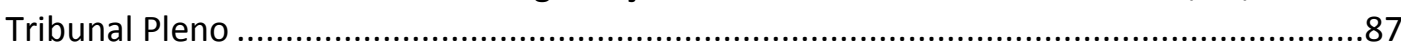

6.2.3 Recurso Ordinário em Mandado de Segurança no. 16.807 - Pernambuco - 6/3/1968

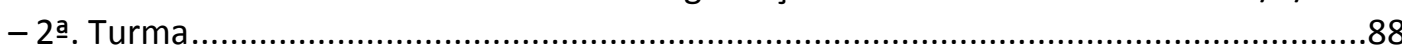

6.2.4. Embargos no Recurso extraordinário no 75.421 - Bahia - 18/9/1975 - Tribunal Pleno

6.2.5. Mandado de Segurança no. 20.999-2 - Distrito Federal - 21/3/1990 - Tribunal Pleno

6.2.6. Recurso Extraordinário no. 131.661 - Espírito Santo - 26/9/1995 - 2a․ Turma .......92

6.2.7. Recurso Ordinário em Mandado de Segurança no. 24.699-9 - Distrito Federal -

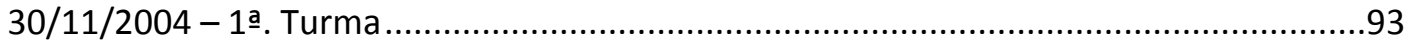

6.2.8. Agravo no Recurso Extraordinário no. 505.439-0 - Maranhão - 12/8/2008 - 2a .

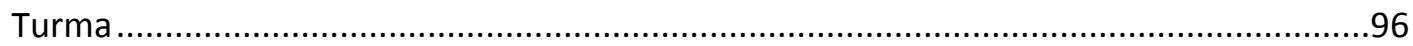

6.2.9. Ag. Reg. No Recurso Extraordinário no. 582.409 - Alagoas - 28/02/2012 - 2a. Turma

6.2.10. Recurso Extraordinário no. 372.186 - Rio de Janeiro - 23/4/2013 - 1a. Turma ......98

6.3. Concessão de licença e permissão 99 
6.3.1. Recurso Extraordinário no. 17126 - Minas Gerais - 31/8/1951 - 2a․ Turma.

6.3.2. Mandado de segurança no. 20.012 - Distrito Federal - 11/12/1974 - Tribunal Pleno 100

6.3.3. Recurso Extraordinário 111.413 - Rio de Janeiro - 23/2/1988 - 2a․ Turma ..........102

6.4. Ato relacionado à expulsão/extradição de estrangeiro .............................................. 102

6.4.1. Habeas Corpus no. 63.815 - São Paulo - 02/04/1986 - Tribunal Pleno .................103

6.4.2. Habeas corpus n‥ 64.345-1 - Distrito Federal - 17/9/1986 - Tribunal Pleno ........103

6.4.3. Extradição no. 1.114-6 República do Chile - 12/6/2008 - Tribunal Pleno ..............104

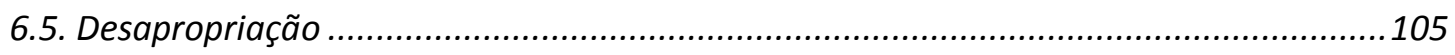

6.5.1. Mandado de segurança no. 20.861 - Distrito Federal - 7/2/1990 - Tribunal Pleno .105

6.6. Revogação de processo licitatório 107

6.6.1. AG.REg. no Agravo de Instrumento 228.554-4 - Minas Gerais - 25/10/2005 - 1a. Turma 107

6.6.2. Recurso Ord. Em Mandado de Segurança no. 24.188-1 - Distrito Federal 14/8/2007- 2a. Turma 108

\section{Superior Tribunal de Justiça}

7.2.1. Recurso Especial no. 1.225/ES, 1… Turma - Julgamento: 14/3/1990

7.2.2. Recurso Especial no. 21.923-5 - 1‥ Turma. Julgamento: 20/5/1992

7.2.3. Recurso Especial nㅇ. 36.611-9, 1a. Turma. Julgamento: 21/6/1994

7.2.4. Recurso Especial no. 63128/GO, 6a Turma. Julgamento: 20/5/1996

7.2.5. ROMS 9319/MG, 1a. Turma. Relator: Garcia Vieira. Julgamento: 9/2/1999

7.2.6. Mandado de Segurança no.8780/DF, 3a . Seção. Relator: Ministro Gilson Dipp. Julgamento: 8/10/2003

7.2.7. Recurso Especial no. 429.570/GO, 2a․ Turma - Relatora: Eliana Calmon. Julgamento: $11 / 11 / 2003$

7.2.8. Recurso Especial no. 575.280/SP, 1… Turma - Relator: Luiz Fux. Julgamento: 2/9/2004

7.2.9. Recurso Ordinário em MS no. 18.151/RJ, 5a. Turma - Relator: Gilson Dipp. Julgamento: 2/12/2004

7.2.10. Recurso em Mandado de Segurança no. 19.210/RS, 5ạ. Turma - Relator: Felix Fischer. Julgamento: 14/3/2005

7.2.11. AgRg nos EDcl no Recurso em Mandado de Segurança no. 17.718, 6a. Turma Relator: Paulo Medina. Julgamento: 11/4/2006

7.2.12. Habeas Corpus no. 56.986/SP, 1a. Seção - Relator: Luiz Fux. Julgamento: $23 / 8 / 2006$ 
7.2.13. Recurso em MS no. 19.741/MT, 5a. Turma - Relator: Felix Fischer. Julgamento: $11 / 3 / 2008$

7.2.14. Recurso Especial no. 778.648/PE, 2a . Turma - Relator: Mauro Campbell Marques. Julgamento: 6/11/2008.

7.2.15. Recurso em MS no. 20.271/GO, 1‥ Turma - Relator: Luiz Fux. Julgamento: 26/5/2009

7.2.16. Recurso Especial no. 1.279.607/PR, 2a . Turma - Relator: Mauro Campbell Marques. Julgamento: 6/12/2011

7.2.17. Recurso em MS no. 35.411/BA, 2a. Turma - Relator: Humberto Martins.

Julgamento: 6/3/2012.

7.2.18. AgRg no AgRg no Recurso Especial no.1.213.843/PR, 1a. Turma - Relator: Napoleão Nunes Maia Filho. Julgamento: 28/8/2012

7.2.19. Recurso em MS no. 37.964/CE, 2a - Turma - Relatora: Eliana Calmon, DJE $30 / 10 / 2012$.

7.2.20. Recurso em MS no. 39.186 - 2a. Turma - Relator: Herman Benjamin. Julgamento:

$21 / 2 / 2013$

7.2.21. AgRg no Recurso em MS no. 38.072/ PE, 2a . Turma - Relator: Herman Benjamin. Julgamento: 28.5.2013

7.2.22. AgRg no Recurso Especial no.1.087.443/SC, 5a. Turma- Relator: Marco Aurélio Bellizze. Julgamento: 04/06/2013

8. Tribunal de Justiça de São Paulo ..............................................................................................146

8.2. Acórdãos selecionados do Tribunal de Justiça de São Paulo..........................................146

8.2.1. Apelaçao Cível №. 36.482 - Relator: Meireles dos Santos. Julgamento: 27/5/1948

8.2.2. Apelação Cível no. 46.926 - 5ạ. Câmara Civil - Relator: Joaquim de Silos Cintra. Julgamento: $24 / 3 / 1950$.

8.2.3. Agravo de Instrumento no. 383.947.5/4 - Comarca de Pitangueiras, 3ạ. Câmara de Direito Público - Relator: Magalhães Coelho. Julgamento: 22/2/2005

8.2.4. Apelação Cível no. 395.016.5/9-00 - Americana, 6ạ. Câmara de Direito Público Relator: Leme de Campos. Julgamento: 7/11/2005

8.2.5. Apelação no. 533.398.5/5-00, 3a. Câmara de Direito Público - Relator: Marrey Uint Julgamento: 5/8/2008.

8.2.6. Apelação Cível no. 865.259.5/8-00 - Ribeirão Preto, 6a. Câmara de Direito Público Relator: José Habice - Julgamento: 14/12/2009.

8.2.7. Apelação Cível no. 588.906.5/2-00 - Santo André, 9ạ. Câmara de Direito Público Relator: Oswaldo Luiz Palu. Julgamento: 9/6/2010....

8.2.8. Apelação Cível no. 990.10.059277-7, 3ạ. Câmara de Direito Público - Relator:

Marrey Uint. Julgamento: 30/11/2010.

8.2.9. Apelação Cível no. 990.10.194745-5, 8ạ. Câmara de Direito Público - Relator:

Cristina Cotrofe. Julgamento: 1/12/2010

8.2.10. Apelação Cível no. 990.10.489240-6 - Jaú 3a . Câmara de Direito Público - Relator:

Magalhães Coelho. Julgamento: 8/2/2011. 
8.2.11. Apelação Cível no. 994.08.110413-3, 2a . Câmara de Direito Público - Relator:

Samuel Junior - Julgamento: 19/4/2011

8.2.12. Apelação Cível no. 9060065-90.2009.8.26.0000, São Paulo - 8ạ. Câmara de Direito

Privado - Relator: Carvalho Viana. Julgamento: 17/10/2012

8.2.13. Reexame Necessário №. 0000700-04.2011.8.26.0159, 11ạ. Câmara de Direito

Público - Relator: Ricardo Dipp. Julgamento: 22/1/2013

8.2.14. Apelação Cível no. 0041683-09.2010.8.26.0053, 8a . Câmara de Direito Público -= Relatora: Maria Cristina Cotrofe. Julgamento: 30/1/2013

8.2.15. Apelação no. 0034542-02.2011.8.26.0053, São Paulo - 8ạ. Câmara de Direito Público - Relator: Paulo Dimas Mascaretti. Julgamento: 8/5/2013.

8.2.16. Apelação no. 0003687-74.2011.8.26.0268, Câmara Especial - Relator: Costabilè e

Solimene. Julgamento: $15 / 4 / 2013$

8.2.18. Apelação com revisão no. 0004833-82.2011.8.26.0129, 4ạ. Câmara de Direito

Público - Relatora: Ana Luiza Liarte. Julgamento: 24/6/2013

8.2.19. Apelação Cível no. 0016363-83.2012.8.26.0053, 5a. Câmara de Direito Público -

Relatora: Maria Paula Tavares. Julgamento: 29/7/2013 


\section{Introdução}

O tema do controle judicial da discricionariedade administrativa constitui matéria bastante estudada pela doutrina nacional e estrangeira. Parafraseando o eminente Professor Celso Antônio" é possível afirmar que "sobre este tema já se verteram rios de tinta".

Nesse sentido, Miguel Sánchez Móron ressalta que é difícil a esta altura dizer algo de novo sobre o tema ${ }^{2}$, muito embora acrescente que, apesar disso, é um problema sempre recorrente:

El control de la discrecionalidad administrativa es um tema clásico de la teoría general del derecho púbico, sobre el que es difícil a estas alturas decir algo nuevo. Sin embargo, es un problema siempre recurrente, sobre el que la polémica jamás parece agotarse. Es lógico que así sea, porque, entre otras cosas, afecta de lleno al equilibrio de poderes, um equilibrio siempre inestable, modificado por la evolución de las circunstancias históricas y que, de tanto en tanto, si no continuamente, necesita recomponerse. De manera que el problema de la discrecionalidad administrativa y su control por los jueces y tribunales, sin perjuicio de sus constantes, debe contemplarse también em uma dimensión histórica.

A despeito desse fato que é inegável, não deixa de ser também um estudo intrigante e desafiador, já que o controle judicial da discricionariedade circula por entre dogmas do direito administrativo como é o caso, por exemplo, do princípio da legalidade e da separação de poderes; além de envolver a definição de limites ao controle judicial sobre os atos da administração. O presente estudo tem por objetivo analisar o controle judicial dos atos discricionários sob a ótica de nossos Tribunais; ou seja, verificar, por meio da análise de algumas de suas decisões, as eventuais alterações no entendimento desse tema.

Parece dotado de lógica razoável, o entendimento de que não é possível ao legislador prever todas as situações possíveis e sobre elas legislar; assim, esse mesmo legislador deixa para a Administração ${ }^{3}$ certa margem de liberdade na apreciação dos casos concretos que se

\footnotetext{
${ }^{1}$ Discricionariedade e controle jurisdicional, p. 9.

${ }^{2}$ Discricionalidad administrativa y control judicial, p. 9.

3 O prof. Edmir Netto de Araújo, em seu livro "Do Negócio Jurídico Administrativo", faz uma análise do vocábulo, assentando que “Administração com'A' maiúsculo, é a máquina estatal, um sistema de entrelaçamento de órgãos e pessoas, em linhas hierárquicas e de subordinação, que compõem o meio de que se utiliza o Poder Público para a concretização de suas finalidades de interesse público, sendo tais funções confiadas a esses organismos sob a direção de um Chefe de Estado. Objetivamente, administração (aqui grafada com 'a' minúsculo) não é conjunto de órgãos, mas a atividade concreta desempenhada por esses órgãos, dirigida direta e imediatamente ao atendimento das necessidades coletivas, dos interesses públicos a eles afetos”. P. 55, apud José
} 
apresentam, podendo escolher, entre as várias alternativas possíveis, aquela que, segundo suas convicções, seja a mais adequada à proteção do interesse público.

A essa margem de liberdade de decisão dada à Administração foi dado o nome Poder Discricionário. Esse Poder Discricionário dá à Administração o poder/dever de praticar os chamados atos discricionários, ou seja, aqueles atos que são praticados levando-se em conta os parâmetros de conveniência e oportunidade.

Allan R. Brewer-Carías, professor na Universidade Central da Venezuela, afirma, citando decisão da Corte Federal daquele país que,

"El principio de la legalidad es la más acabada garantia establecida en el Estado de derecho en beneficio de los administrados, «contra las posibles arbitrariedades de la autoridade ejecutiva» ${ }^{4}$, para lo cual, el ordenamiento jurídico debe establecer el marco legal de la misma. Sin embargo, no toda la actividad a cargo de la Administración tiene que tener establecida «precisos límites» em dicho ordenamiento a los cuales deba aquella ceñirse, por lo que em muchos casos es la propia ley la que otorga a la Administración amplios poderes de apreciación de la oportunidad y conveniência para la tomada de decisiones."

Considerando que o poder discricionário é condição para que a administração possa atuar de forma eficiente buscando sempre o interesse público, é certo que sua limitação é absolutamente indispensável para que o Estado não se torne arbitrário e os administrados não fiquem expostos ao arbítrio daqueles que detêm o poder em seu nome. Assim, torna-se imperioso conciliar, de um lado, a existência do poder discricional e, de outro, a salvaguarda dos direitos dos administrados resultante da limitação desse poder.

O trabalho não pretende fazer uma incursão pormenorizada nas construções doutrinárias, buscará fazer, apenas, uma contextualização sobre o tema da discricionariedade, incluindo sua evolução histórica, além de uma breve abordagem sobre os parâmetros destinados a limitar a atividade discricionária. Na sequência, uma análise da

Cretella Jr., Dir. Adm. Bras., Ed. Forense, 1983, p. 51; Manual de D. Adm. Forense, p. 1. Sublinha, ainda, que "na verdade é difícil, ao conceituar 'Administração' e 'administração', dissociar estes vocábulos da palavra ‘Governo', pois não é só Governo (poder Executivo), nem só a a máquina administrativa e seu pessoal (ótica forma), nem ainda só a atividade, material ou jurídica por ela desenvolvida (ótica material), mas tudo isso, conforme o aspecto focalizado. De acordo com Cretella Jr., é a 'atividade que o Estado desenvolve, por meio de seus órgãos, para a consecução do interesse público'.” P. 56 , apud José Cretella Jr., Manual de direito administrativo, Ed. Forense, 1989, p. 19.

${ }^{4}$ Corte Federal (Venezuela) sentencias de 17 de julio o 23 de octubre de 1953, Gaceta Forense No. 1, Caracas 1953, p. 151 y No. 2, Caracas 1953, p. 64; in Notas sobre La Discrecionalidad Administrativa, Y aobre Su Delimitación Y Sus Límites. Allan R. Brewer-Carías, p. 1.

${ }^{5}$ Notas sobre la discrecionalidad administrativa, y sobre sus delimitación y sus límites 
jurisprudência de nossos Tribunais para verificar quais os parâmetros utilizados para adentrarem na seara da discricionariedade praticada pela administração e se há uma preocupação dos Tribunais em estabelecer limitações a essa ingerência.

Discorrendo sobre a evolução histórica do tema da discricionariedade, Di Pietro afirma que,

estudando-se a evolução da Administração Pública a partir do Estado de Polícia, verifica-se que se partiu de uma idéia de discricionariedade ampla sinônimo de arbítrio, próprio das monarquias absolutas, em que os atos da Administração não eram sindicáveis perante o Judiciário - para passar-se a uma fase, já no Estado de Direito, em que a discricionariedade, assim entendida, ficou reduzida a certos tipos de atos; e chegou-se a uma terceira fase em que praticamente desapareceu essa idéia de discricionariedade e esta surgiu como poder jurídico, ou seja, limitado pela lei. ${ }^{6}$

Com o desenvolvimento do Estado Social de Direito houve um aumento nas atribuições da Administração, tarefas essas (construção de estradas e de caminhos de ferro, abastecimento de água, luz e gás, saúde pública e educação, etc) que passaram a exigir um complexo e vasto fluxo de leis e regulamentos.

Acrescente-se a introdução de uma principiologia da boa Administração, que ampliou a possibilidade de sindicabilidade dos atos ditos discricionários, já que o controle judicial poderia corrigir os atos administrativos que fossem praticados com a inobservância desses valores.

Inicialmente, verifica-se que o controle se restringia a aspectos puramente formais dos atos administrativos, ou seja, relativos apenas à competência e à forma. Dessa análise puramente formal partiu-se para uma análise material, ampliando o exame para os fins e fatos determinantes do ato administrativo. À medida que a lei foi adquirindo seu sentido axiológico perdido na época do Estado Liberal, novos princípios foram sendo elaborados como formas de limitar a discricionariedade e, paralelamente, ampliar a esfera de controle do Poder Judiciário. ${ }^{7}$

\footnotetext{
${ }^{6}$ Discricionariedade Administrativa, $2^{\mathrm{a}}$. ed., p. 14.

${ }^{7}$ Ibidem, p. 15.
} 
Constitucionalmente, o Judiciário recebeu a atribuição de apreciar qualquer lesão ou ameaça de direito que lhe venha a ser submetida (art. $5^{\circ}, \mathrm{XXXV}$ da CF) ${ }^{8}$. Assim, partindo-se dessa premissa, os atos da Administração, de qualquer natureza, incluindo os discricionários, seriam passíveis de controle judicial.

Feitas essas breves considerações introdutórias, o que se pretende com a presente pesquisa é analisar algumas das decisões dos Tribunais Superiores, em especial do Supremo Tribunal Federal e Superior Tribunal de Justiça e verificar como são julgadas as questões que envolvem a discricionariedade administrativa.

\footnotetext{
8 "A idéia segundo a qual "onde quer que haja um direito individual violado, há de haver um recurso para a debelação da injustiça" apresentada ao Supremo Tribunal Federal por Rui Barbosa, em 1982 e baseada na doutrina de Marshall, antes de ser agasalhada pelas Constituições brasileiras, foi positivada no art. 75 do CC de 1916, que dizia que "a todo direito corresponde uma ação que o assegura". As Constituições de 1824,1891, 1934 e 1937não expressaram normas com semelhante conteúdo. O princípio da proteção jurisdicional apenas foi constitucionalizado em 1946 que, na sua declaração de direitos e garantias individuais, afirmou que 'a lei não poderá excluir da apreciação do Poder Judiciário qualquer lesão de direito individual' (art. 141, par. $4^{\circ}$.). O princípio, consagrado na Constituição de 1946, foi repetido na Constituição de 1967(art. 150, 4.) e na Emenda Constitucional n. 1, de 1969 (art. 153, 4 ). A Constituição de 1988 inseriu a locução 'ameaça a direito' na verbalização de tal princípio 'a lei não excluirá da apreciação do Poder Judiciário lesão ou ameaça a direito', deixando claro que a lei, além de não poder excluir lesão, não poderá excluir 'ameaça a direito' da apreciação do Poder Judiciário. Além disto, desapareceu a alusão a 'direito individual' constante das Constituições anteriores. O objetivo desta foi ressaltar que os direitos difusos e coletivos também estão protegidos pela garantia da tutela jurisdicional efetiva". Luiz Guilherme Marinoni,, in: Comentários à Constituição do Brasil, J.J. Gomes Canotilho et al., p. 356.
} 


\section{Parte 1 - discricionariedade - generalidades}

\section{Evolução histórica da administração pública - discricionariedade - controle da administração}

Sublinha Di Pietro que a Administração, tanto no sentido subjetivo ${ }^{9}$, quanto no sentido objetivo $^{10}$ estruturou-se na fase do Estado de Direito, tendo como base o princípio da separação de poderes, cuja distinção entre as três funções do Estado limitou o exercício do poder e proclamou e garantiu os direitos fundamentais do homem, dentre eles, a liberdade e a igualdade. ${ }^{11}$

Tal conclusão, entretanto, não afasta a ideia de que em épocas anteriores já existisse o que chamamos de "administração pública", porque havendo a figura do Estado, deve haver órgão ou órgãos incumbidos do exercício das funções administrativas. ${ }^{12}$

Edmir Netto, ao fazer referência ao nascimento do Direito Administrativo como ciência, afirma que em todas as épocas existiram instituições administrativas e órgãos administrativos sempre editaram regras destinadas a disciplinar e dirigir seus serviços e funcionários, mas como bem lembra o professor, somente a partir do século XIX é que o Direito Administrativo estrutura-se como ciência. ${ }^{13}$

A concepção de uma Administração Pública submissa à lei teve início no período da história chamado de Estado Moderno.

\subsection{Primeira fase do Estado Moderno - Estado de Polícia}

A fase inicial do Estado Moderno é conhecida por "Estado de Polícia". O termo polícia é utilizado no sentido de atividade administrativa; portanto, as atividades de polícia são o conjunto de atividades do Estado.

\footnotetext{
${ }^{9}$ Conjunto de pessoas e órgãos que exercem a função administrativa do Estado.

${ }^{10}$ Atividade concreta e imediata que o Estado desenvolve para a consecução dos interesses coletivos.

${ }^{11}$ Discricionariedade Administrativa na Constituição de 1988, p. 5.

${ }^{12}$ Ibidem, p. 5.

${ }^{13}$ Curso de Direito Administrativo, $4^{\mathrm{a}}$. ed., p. 6.
} 
Como assinalam Wolff, Bachof e Stober, "do ponto de vista da ciência administrativa, o Estado absoluto é chamado de 'Estado de Polícia' devido à sua ampla competência administrativa. Pelo conceito de 'polícia' entendia-se naquela época o conjunto da Administração interna (com exceção do exército e das finanças)". ${ }^{14}$

As monarquias nacionais tiveram, na crise do feudalismo ${ }^{15}$, em que o enfraquecimento do poder local da nobreza abriu espaço para a ação política dos reis, a condição fundamental para o processo de sua formação. Além da crise do sistema feudal (proliferação de proprietários rurais, aumento da produção, a desorganização na distribuição de feudos, o insustentável sistema de imposto de passagem ${ }^{16}$ tem início também a perda do prestígio que a igreja ${ }^{17}$ até então detinha, o que levou a uma concentração de poder, como solução para promover a unidade do Estado, totalmente inexistente no período feudal. ${ }^{18}$

A centralização foi também favorecida pelo desenvolvimento comercial e urbano. Havia interesse econômico, na ideia de unificação, pela nova classe social ligada ao comércio. Atingir a unificação, para a burguesia, relacionava-se à centralização do poder. A crise de crescimento do século XIV somente cederia com a conquista de novos mercados e novas rotas. Somente o rei poderia reunir recursos para bancar a expansão comercial e marítima. E mais, um "poder forte era indispensável para que as decisões impostas pelas lutas políticas e econômicas entre as nações fossem tomadas rapidamente"19.

\footnotetext{
${ }^{14}$ Direito Administrativo, vol. I, p. 105;

15 Como sublinham Bachof, Wolff e Stober, "O império medieval e os instrumentos de poder a ele associados não eram Estados no sentido moderno, dotados de poder estadual unitário e soberano. A sua base não eram territórios de domínio e organização, mas os compromissos pessoais entre dominadores e dominados. Assim, o império não era ainda uma autarquia, mas uma federação das pessoas caracterizadas pelo domínio senhorial". Direito Administrativo, v. I, p. 95.

${ }^{16}$ Luis Felipe Ferrari Bedendi, p. 280, in Supremacia do interesse Público e outros Temas relevantes do direito Administrativo, coord. Maria Sylvia Zanela Di Pietro e Carlos Vinícius Alves Ribeiro.

17 Sobre a atuação da Igreja escreve Rogério Dutra dos Santos, citando Tigar Michael E. e Levy, Madeleine R., p. 37, “Assim, a Igreja veio a participar como grande senhor feudal, já que despontou como proprietária de vastas extensões de terra e, por seu poder espitritual e temporal abranger toda a Europa durante o período medieval, foi certamente a única instituição sólida existente. As poucas cidades que sobreviveram à desintegração do Império Romano foram, por conseguinte, mas cidades episcopais e arcebispais”. Fundamentos da História do Direito, organizador Antonio Carlos Wolkmer, p. 222.

18 “A aspiração à antiga unidade do Estado Romano, jamais conseguida pelo Estado Medieval, iria crescer de intensidade em consequência da nova distribuição da terra. Com efeito, o sistema feudal, compreendendo uma estrutura econômica e social de pequenos produtores individuais, constituída de unidades familiares voltadas para a produção de subsistência, ampliou o número de proprietários, tanto dos latifundiários quanto dos que adquiriram o domínio de áreas menores. Os senhores feudais, por seu lado, já não toleravam as exigências de monarcas aventureiros e de circunstância, que impunham uma tributação indiscriminada e mantinham um estado de guerra constante, que só causavam prejuízo à vida econômica e social." Dalmo de Abreu Dallari, p. 70.

19 Arruda, José Jobson de A.. História Moderna e Contemporânea, p. 62.
} 
Assinala ainda José Jobson Arruda que "a teoria do poder absoluto apresentava o rei como representante de Deus na terra, defensor da Igreja e da Pátria, protetor das Artes, legislador e representante do Estado (cujos interesses estavam acima dos interesses particulares ou individuais)". ${ }^{20}$

Enquanto na França o poder real caminhava para o absolutismo, na monarquia inglesa os reis cediam lugar a monarcas limitados, estabelecendo uma monarquia constitucional. $\mathrm{Na}$ Inglaterra, o poder real passou a se firmar no início do século XVI, com a dinastia Tudor, da qual Henrique VIII foi o segundo rei da dinastia. Henrique VIII impôs sua autoridade aos nobres, graças ao apoio da burguesia interessada na expansão comercial. A luta com a igreja permitiu assumir o controle das propriedades eclesiásticas na Inglaterra. O rei tornou-se, então, chefe da igreja anglicana.

Elizabeth I, filha de Henrique VIII, foi a responsável pela implantação de fato do poder político absoluto. Restava, agora, torna-lo de direito, ou seja, legalizar o poder real e apresenta-lo como de origem divina. Elizabeth I desencadeou violenta perseguição religiosa, tanto a católicos como a protestantes, impôs o anglicanismo; concedeu monopólios comerciais e industriais aos comerciantes e empresa, aumentando as rendas da nação ${ }^{21}$.

Na França, o melhor exemplo de absolutismo deu-se no governo de Luís XIV, cuja síntese das ideias absolutistas encontra-se na frase "L'Êtat c'est moi".

Para combater o poder absoluto do rei, foi elaborado por doutrinadores alemães, a teoria do fisco ${ }^{22}$, segundo a qual o patrimônio público não pertenceria ao príncipe, mas ao fisco, tendo personalidade de direito privado.

Assinalam Wolff e Bachof que o monarca absoluto transformou-se "de simples guardião do direito em livre criador de direito, em sentido literal absoluto (legibus solutus),

\footnotetext{
${ }^{20}$ Arruda, José Jobson de A..História Moderna e Contemporânea, p. 62.

${ }^{21}$ Ibidem, p. 68.

${ }^{22}$ Segundo Wolff, Bachof e Stober, “A Administração do Estado de polícia apresentou-se, face ao cidadão sob duas formas de manifestação: como pessoa jurídica de direito público e como pessoa jurídica de direito civil, ocupando-se nesta qualidade de assuntos privados ou de direito patrimonial (o chamado fisco). Quando a administração interferia como pessoa jurídica de direito público nos direitos do particular, podia salvaguardar-se contra eventuais recursos do particular invocando os privilégios de autoridade de non appellando e de non evocando. Quando o fisco interferia nos direitos do particular, este podia exigir uma indenização... Por conseguinte, a criação da figura jurídica do 'fisco' foi uma construção auxiliar, porque no lugar da 'autoridade' (Obrigkeit) podia ser responsabilizado um ente jurídico autónomo.” Direito Administrativo, v. I, p. 108.
} 
que, especialmente mediante invocação de 'necessitas' ou da 'salus publica', modificava, anulava e suspendia o direito positivo...,23

A Administração Pública não estava vinculada a nenhum tipo de norma que limitasse sua atividade, senão a que viesse do monarca. Era o império do arbítrio, não no sentido de injusto, mas na ideia de ausência de limitações legais. ${ }^{24}$

\subsection{Segunda fase do Estado moderno - Estado liberal de direito}

Esta segunda fase teve início com o fim das monarquias absolutistas e foi estruturada sobre os princípios da legalidade, igualdade e separação de poderes, que visavam assegurar a proteção dos direitos individuais, tanto nas relações entre particulares como nas relações entre esses e o Estado. ${ }^{25}$

Nesse período, a atuação do Estado era tida como negativa, já que a ele caberia apenas assegurar os direitos individuais, sem maior atuação ou interferência na sociedade. ${ }^{26}$

Sublinha Dinorá Adelaide Musetti Grotti que, a concepção liberal clássica traduz a ideia de um Estado com funções reduzidas, defendendo a necessidade de limitação do poder político; bem como de projetar a atuação estatal à segurança, à justiça e à proteção dos direitos individuais, $(\ldots){ }^{27}$

Nesse período passa a vigorar o princípio da legalidade da Administração, segundo o qual se faz necessária a autorização legal para qualquer ingerência da Administração na esfera de liberdade e na propriedade do cidadão, a chamada de reserva de lei. Além do que, qualquer alteração, revogação ou anulação de lei somente poder ser feita por uma nova lei formal, não por simples ato de autoridade administrativa (primado da lei). ${ }^{28}$

A legalidade aparece como a resposta, como a solução destinada a conter os abusos cometidos no período absolutista.

\footnotetext{
${ }^{23}$ Direito Administrativo, v. I, p. 107.

${ }^{24}$ Discricionarieddde Administrativa na CF 1988. P. 8/9.

${ }^{25}$ Maria Sylvia Zanella Di Pietro, Discricionariedade Administrativa, p. 20.

${ }^{26}$ Luis Felipe Ferrari Bedendi, p. 282, in Supremacia do interesse Público e outros Temas relevantes do direito Administrativo, coord. Maria Sylvia Zanela Di Pietro e Carlos Vinícius Alves Ribeiro.

${ }^{27}$ Dinorá Adelaide Musetti Grotti. O Serviço Público e a Constituição de 1988, p.

${ }^{28}$ Bachof, Otto; Wolff, Hans J., Stober, Rolf. Direito Administrativo, v. I, p. 110.
} 
A partir desse período, a composição de qualquer conflito entre o indivíduo e o Estado não se faria mais autoritariamente, mas juridicamente; era a superação do arbítrio pelo direito. As normas de direito público ganharam dupla função: de limitar o poder do Estado; de garantir os indivíduos e os grupos secundários por eles instituídos contra os excessos e desvios ilegais praticados pelo Estado. ${ }^{29}$

A Administração Pública no Estado liberal por ter se limitado à manutenção da segurança externa e da ordem interna é também chamado de Estado de direito de salvaguarda. O Estado tinha o dever de criar condições para o desenvolvimento livre e a conformação social da 'sociedade civil'. Essa estratégia significou uma maior autonomia privada e a limitação à administração das infraestruturas, bem como, na economia, na liberdade de indústria. ${ }^{30}$

O sucesso da Revolução Francesa - e com ela, a concretização das ideias fillosóficas de Voltaire, Rousseau e de Montesquieu - que influenciou os países vizinhos da Europa, foi responsável por fazer despontar a ideia de separação de poderes.

No Estado de Direito, a relação do príncipe com os súditos e a dos súditos entre si passaram a se sujeitar, obrigatoriamente, ao império da $l \mathrm{i}^{31}$; entretanto, o princípio da legalidade para a Administração Pública apresentava sentido diferente do adotado atualmente, já que esta podia fazer tanto quanto os particulares, ou seja, fazer tudo o que não era vedado pela lei.

Nesse modelo, com a atuação mínima do Estado, limitada apenas a assegurar os direitos individuais, acabou por produzir graves consequências no âmbito econômico e social; as grandes empresas transformam-se em grandes monopólios, aniquilando as de menor porte; tem início o surgimento da classe social do proletariado, em condições de miséria, doença e ignorância, que só se agravam face à política do não intervencionismo estatal. $^{32}$

Assinala Di Pietro que,

“estudando-se a evolução da Administração Pública a partir do Estado de Polícia, verifica-se que se partiu de uma ideia de discricionariedade ampla sinônimo de arbítrio e própria das monarquias absolutas, em que os atos da

\footnotetext{
${ }^{29}$ Moreira Neto, Diogo de Figueiredo, p. 13/14.

${ }^{30}$ Bachof, Otto; Wolff, Hans J., Stober, Rolf. Direito Administrativo, v. I, p. 111.

${ }^{31}$ Edimur Ferreira de Faria. Controle do Mérito do Ato Administrativo pelo Judiciário p. 45.

${ }^{32}$ M.S.Zanella Di Pietro, Discricionariedade Administrativa, p. 28.
} 
Administração não eram sindicáveis perante o Judiciário - para passar-se a uma fase, já no Estado de Direito, em que a discricionariedade, assim entendida, ficou reduzida a certos tipos de atos; e chegou-se a uma terceira fase em que praticamente desapareceu essa ideia de discricionariedade e esta surgiu como poder jurídico, ou seja, limitado pela lei". ${ }^{33}$

\subsection{Estado social de direito}

O Estado liberal, ante a cruel realidade a que se submetia a maioria de sua população, e questionado pelo movimento comunista encabeçado por Karl Marx e Engels, reconheceu que não estava desempenhando o seu principal papel, qual seja, o de prestar o bem social e o de respeitar a dignidade humana. ${ }^{34}$

A ideia de não intervencionismo, de limitação da atuação do Estado apenas à proteção da liberdade e igualdade, mostrou-se insuficiente face à profunda desigualdade social gerada; assim, após a 2a Grande Guerra consolidou-se o Estado Social, chamado também de Estado do Bem-Estar ou Estado Providência. Não mais era cabível que o Estado atuasse apenas como mero expectador das relações privadas, ao contrário, era necessário garantir que elas produzissem o mínimo adequado a uma existência digna, no âmbito da educação, saúde, previdência moradia e trabalho, por exemplo. ${ }^{35}$

O desenvolvimento do Estado Social de Direito provocou um aumento nas atribuições da Administração, tarefas essas (construção de estradas e de caminhos de ferro, abastecimento de água, luz e gás, saúde pública e educação, etc) que passaram a exigir um complexo e vasto fluxo de leis e regulamentos.

Esse aumento de atribuições a cargo do Estado - que se transformou em Estado prestador de serviços, em Estado empresário, em Estado investidor - fez com que houvesse um fortalecimento do Poder Executivo, já que a maioria das atribuições ficou a cargo desse Poder, gerando, como consequência, um abalo no princípio da separação de poderes.

Como bem observa Di Pietro,

\footnotetext{
${ }^{33}$ Discricionariedade Administrativa, $2^{\mathrm{a}}$. ed., p. 14.

${ }^{34}$ Edimur Ferreira de Faria, p. 55.

${ }^{35}$ Luis Felipe Ferrari Bedendi, p. 283, in Supremacia do interesse Público e outros Temas relevantes do direito Administrativo, coord. Maria Sylvia Zanela Di Pietro e Carlos Vinícius Alves Ribeiro.
} 
O Poder Executivo, para atuar, não podia ficar dependendo de lei, cujo processo de promulgação dependia (e depende ainda) de um complexo e demorado procedimento legislativo.

Como consequência, passou-se a conferir atribuição normativa ao Poder Executivo, que veio a exercer essa competência por meio de decretosleis, leis delegadas, regulamentos autônomos. O legislador, em inúmeros casos, passou a adotar a técnica de editar fórmulas gerais, standards, para serem completadas pelo Executivo; este deixou de ser apenas executor de normas postas pelo Legislativo. ${ }^{36}$

Nessa época, a vinculação e a discricionariedade consolidaram-se no sentido de que à Administração cabe fazer apenas o que a lei determina ou autoriza, não sendo possível atuar nos espaços em branco deixados. A discricionariedade transformou-se num poder jurídico da Administração limitado pela lei. ${ }^{37}$

Segundo afirma Di Pietro, nesse período, o direito administrativo ${ }^{38}$ cresceu $^{2}$ paralelamente ao acréscimo das funções estatais que ficaram a cargo da Administração Pública. $^{39}$

Nesse período houve um crescimento das funções estatais e, também, no rol dos serviços públicos assumidos pelo Estado, que, ao abranger atividades de natureza social e econômica, que eram, até então, reservadas aos particulares, conduziu a uma crise na noção de serviço público. ${ }^{40}$

Em relação ao poder de polícia, houve também relevante ampliação, vez que a administração passou a atuar em setores que nada tinham a ver com segurança, atingindo, de

\footnotetext{
36 M.S.Zanella Di Pietro, Discricionariedade Administrativa, $2^{\text {a }}$. ed., p. 31.

${ }^{37}$ Luis Felipe Ferrari Bedendi, p. 283, in Supremacia do interesse Público e outros Temas relevantes do direito Administrativo, coord. Maria Sylvia Zanela Di Pietro e Carlos Vinícius Alves Ribeiro.

38 Assinala Maria Sylvia Zanella Di Pietro que, O direito administrativo criou princípios e institutos que derrogaram em grande parte postulados básicos do individualismo jurídico: $\mathrm{O}$ reconhecimento de privilégios para a Administração opõe-se ao ideal da igualdade de todos perante a lei; a criação, pelo Estado, de entidades públicas ou privadas, com personalidade jurídica própria, coloca intermediários entre o Estado e o indivíduo, contrapondo-se aos anseios que inspiraram a Lei Le Chapelier; a atribuição de uma função social à propriedade privada derroga o caráter absoluto com que esse direito era visto pelo direito civil do século XVIII; a imposição de normas de ordem pública para reger as relações contratuais afeta o princípio da autonomia da vontade; a aplicação da cláusula 'rebus sic stantibus' atinge o princípio da força obrigatória dos contratos; em termos de responsabilidade civil, a ideia de risco, em várias hipóteses de danos causados a terceiros, substitui a culpa, por considerar-se que esta nem sempre levava à solução mais justa. Discricionariedade Administrativa. Discricionariedade Administrativa na Constituição de 1988, p. 34.

39 M.S.Zanella Di Pietro, Discricionariedade Administrativa, p. 33.

${ }^{40}$ Como sublinha Maria Sylvia Zanella Di Pietro: Isso porque o Estado passou a transferir a execução de grande parte dessas atividades a particulares, pro meio de concessão de serviços públicos e, posteriormente, mediante a criação de sociedades de economia mista e empresas públicas para execução sob regime jurídico predominantemente privado. A partir daí, o elemento subjetivo da noção (prestação pelo Estado) e o elemento formal (regime jurídico publicístico) foram profundamente afetados. Discricionariedade Administrativa na Constituição de 1988, p. 34.
} 
um lado, as relações entre particulares ${ }^{41}$, e, de outro, passou a impor obrigações (o cultivo da terra, o aproveitamento do solo, a venda de produtos).

Como consequência de toda essa ampliação, como não poderia deixar de ocorrer, houve um crescimento da máquina estatal e a consolidação da burocracia (como forma de organização e gestão administrativa).

No final da década de 60 e início da de 70, esse modelo de Estado Social entrou em decadência, em razão, principalmente, do elevado custo da política de assistência; do custo exorbitante da máquina estatal e, também, pela crise do petróleo.

Tais dificuldades concorreram para o surgimento de outro modelo de Estado, atual Estado Democrático de Direito.

\subsection{Estado Democrático de Direito}

O fracasso do Estado do bem-estar social, que se mostrou bastante intervencionista, assim como o desejo de democracia manifestado nas revoluções do século XVIII ressurge numa tentativa de aproximar o Estado do povo para que juntos adotem, democraticamente, políticas públicas de interesse da sociedade. ${ }^{42}$

Jose Afonso da Silva destaca que:

a democracia que o Estado Democrático de Direito realiza há de ser um processo de convivência social numa sociedade livre, justa e solidária (art. $\left.3^{\circ}, \mathrm{I}\right)$, em que o poder emana do povo, e deve ser exercido em proveito do povo,...É um tipo de Estado que tende a realizar a síntese do processo contraditório do mundo contemporâneo, superando o Estado capitalista para configurar um Estado promotor de justiça social.. ${ }^{43}$.

\footnotetext{
${ }^{41}$ Leciona Maria Sylvia Zanella Di Pietro que,"o próprio conceito de ordem pública, antes concernente apenas à segurança, passou a abranger a ordem econômica e social, com medidas relativas às relações de emprego, ao mercado dos produtos de primeira necessidade, ao exercício das profissões, às comunicações, aos espetáculos públicos, ao meio ambiente, ao patrimônio histórico e artístico nacional, à saúde e tantos outros". Discricionariedade Administrativa na Constituição de 1988, p. 34.

${ }^{42}$ Edimur Ferreira de Faria, p. 56/57.

${ }^{43}$ Curso de Direito Constitucional Positivo, p. 119/120.
} 
Nesse modelo busca-se acrescentar ao Estado Social de Direito, a participação do povo no processo político, nas decisões de Governo e no Controle da Administração Pública; além disso, busca-se também, vincular a lei aos ideais de justiça, submetendo-se o Estado ao Direito ${ }^{44}$, não somente à lei em sentido puramente formal, mas também a todo arcabouço de princípios.

Ao referir-se a esse modelo de Estado, Realça Luis Felipe Ferrari Bedendi que nele,

Viu-se o fortalecimento das Constituições, as quais deixaram de ser meramente o documento normativo de onde as demais normas do sistema retiravam sua validade, concepção defendida pelo positivismo jurídico até então dominante, para se tornarem o documento normativo que sintetiza e agrega os princípios, valores e regras de maior relevância em dado momento, servindo como vetores de aplicação e interpretação de todo o sistema.

A estrutura da vinculação e da discricionariedade passa também a sofrer influência dessa chamada constitucionalização do direito. A ideia inicial de que a Administração só deve fazer o que a lei determina foi elastecida; lei não deve mais ser entendida em seu sentido estrito, formalista, mas, amplo, abrangendo também os princípios e valores constitucionais, sob pena de revisão de seus atos pelo Poder Judiciário.

Assim, o princípio da legalidade, expressamente previsto na Constituição Federal no artigo 37, pode ser concebido em dois sentidos: num sentido restrito (reserva legal), para designar que determinadas matérias sejam reservadas à lei em sentido formal (artigo 59 da Constituição); em sentido amplo, para abranger a lei em sentido formal, os atos normativos do Poder Executivo e de órgãos e entidades que compõem a Administração Direita e Indireta, além dos princípios consagrados na Constituição, de modo implícito ou explícito ${ }^{45}$.

\footnotetext{
44 "L'État de droit est le produit d'um processos de constitutionnalisation du droit; dans tous le pays, ce processos commence par une manifestation du pouvoir originaire, et continue par la formation du droit; puis arrive um moment òu les opinions publiques revendiquent toujours plus de garanties pour l'exercice des libertés reconnues dans les Constitutions. Plus de liberte passe par plus de droit (um droit qui reconnait les pouvoirs de droit et em multiplie les garanties, plus que le droit qui réglemente et em perfectionne les conditions d'exercice).” Mélanges René Chapus . par Claude Goyard. Droit administratif, p. 299/300.

${ }^{45}$ Sobre o princípio da legalidade administrativa, Merkl assim se expressa: "Este principio de "Legalidad de la Administracion o 'La Administración Legal'suele ser interpretado de las más diversas maneras por sus representantes. Su significado de menos trascendência es aquel que lo limita a que la administración no puede violar las leyes vigentes o, em términos positivos, que debe moverse dentro de los limites de las leyes vigentes. Uma interpretación más ampla es la que supone que para determinadas actuaciones administrativas, a saber, las que afectan a la libertad y la propiedad, se exige um fundamento legal expresso. Pero la concepción más consecuente es la que supone em esse principio la exigência de um fundamento legal para cada uma de las actuaciones administrativas, cualquiera que sea su contenido. De todas maneras, em todas sús formulas, el principio se revela em relación necesaria com la ley, com el condicionamiento mediante la ley."Adolfo Merkl. Teoría General del Derecho Administrativo, p. 209/210.
} 
Nessa nova concepção, a ideia de mérito do ato "vem sofrendo críticas por parte da doutrina, que considera insustentável admitir-se um conteúdo produzido pela Administração livre da apreciação judicial, sem a verificação da observância dos princípios"46.

\section{Discricionariedade - Considerações gerais}

A expressão 'discricionariedade', antes de constar das obras de direito administrativo, era utilizada para indicar o atributo do soberano, expressando sua aptidão e a de seus agentes para bem desempenhar suas funções. ${ }^{47}$ Tem sua origem no antigo Estado europeu dos séculos XVI e XVII, que expressava a soberania decisória do monarca absoluto (voluntas regis suprema lex - a vontade do rei é a lei suprema). The King can do not wrong (o rei não pode errar) e do quod principi placuit legis habet vigoren (aquilo que agrada ao príncipe tem força de lei), além da célebre frase, L'État c'est Moi (o Estado sou eu) de Luiz XIV, eram princípios que estruturavam o Estado chamado de Polícia. ${ }^{48} \mathrm{~A}$ ideia original de discricionariedade estava vinculada à arbitrariedade do poder político próprio do absolutismo. ${ }^{49}$

Otto Bachof, Hans J. Wolff e Rolf Stober escreveram acerca da discricionariedade,

A discricionariedade é certamente um conceito fundamental do direito administrativo e um instrumento central de orientação da actuação da Administração. No entanto, não existe unanimidade sobre o significado e as diversas facetas desta figura jurídica. Pelo contrário, a doutrina da discricionariedade faz parte das questões controversas clássicas da comunidade científica e da jurisprudência.. ${ }^{50}$

\footnotetext{
${ }^{46}$ Luis Felipe Ferrari Bedendi in Supremacia do Interesse Público e outros temas relevantes do Direito Administrativo, coordenação Maria Sylvia Zanella Di Pietro e Carlos Vinícius Alves Ribeiro, p. 286.

${ }^{47}$ Odete Medauar. Direito administrativo moderno, p. 120.

${ }^{48}$ De acordo com José Reinaldo de Lima Lopes, O soberano detém, no entanto, todos os poderes do Estado, isto é, não há "poderes" colocados em pessoas separadas. Há, sim, órgãos separados que exercem, por delegação do rei, as funções típicas do Estado: justiça, governo, fazenda e guerra.

....Dessas áreas todas, a da justiça tornou-se a mais autônoma. Em toda parte os tribunais reais têm certa autonomia e, por isso, seus membros convertem-se em indivíduos e grupos privilegiados. Há extensa regulamentação das atividades, do acesso, da forma de proceder dos tribunais.

....Já, na esfera do governo, a liberdade do soberano é maior, daí o incremento progressivo de sua atividade nessa área, legislando cada vez mais sobre matéria de polícia (política) no que diz respeito à vida econômica, à organização das atividades mercantis, aos pesos e medidas, e assim por diante," Curso de história do direito, p.120-1.

${ }^{49}$ Gustavo Binembojm, Uma Teoria do Direito Administrativo, p. 195/196.

${ }^{50}$ Hans J. Wolff; Otto Bachof e Rolf Stober, tradução António F. de Sousa. Direito Administrativo, vol. 1, p. 461.
} 
Como sublinha Odete Medauar ${ }^{51}$, doutrinadores franceses, na segunda metade do século XIX faziam referência a 'atos de pura administração' para designar as decisões resultantes do que chamamos hoje de poder discricionário. Em fins do século XIX e início do século XX a expressão já passa a fazer parte da linguagem doutrinária e jurisprudencial do direito administrativo.

Inicialmente, discricionariedade esteve relacionada à ideia de escolha livre, à margem da disciplina legal e baseada somente em apreciações subjetivas da autoridade. Até o início do século XIX, na França, os atos de pura administração - discricionários - eram tidos como insuscetíveis de apreciação pelo juiz ${ }^{52}$. Em 1908, como assenta Odete Medauar ${ }^{53}$, o Conselho de Estado da França deixou de admitir a existência de atos totalmente livres, impondo a observância de regras de competência e de forma. Germana Morae ${ }^{54}$ s destaca que "a ação administrativa comportava duas expressões: uma vinculada - 'reconduzível à execução da lei', concretizada através ‘de atos de gestão' e outra livre ou discricionária, 'não sujeita a qualquer vinculação jurídica', materializada em 'atos de império' - à margem do Direito e imune à revisão dos órgãos judiciais".

Posteriormente, um novo elemento passou a ser considerado, o atendimento ao interesse público. Desenvolveu-se, assim, como ressalta Odete Medauar ${ }^{55}$, o conceito de que o poder discricionário consistia na liberdade de apreciação, mas com vistas ao atendimento do interesse público.

Como reflexo da necessidade de que a decisão fosse determinada por razões objetivas de interesse público, passou-se a exigir o nexo entre a decisão administrativa e seus antecedentes (circunstância de fato). Com o motivo inseriu-se mais um vínculo no exercício do poder discricionário.

Destaca Odete Medauar que, atualmente, no âmbito de um Estado de Direito, não é mais possível aceitar-se um poder discricionário fora do Direito, subtraído a toda disciplina legal. A discricionariedade representa uma condição de liberdade, mas não uma liberdade ilimitada. O poder discricionário sujeita-se não só às normas específicas para cada situação,

\footnotetext{
${ }^{51}$ Direito Administrativo Moderno, p. 120.

52 Ibidem, p. 120/1.

${ }^{53}$ Ibidem, p. 120.

${ }^{54}$ Controle Jurisdicional da Administração Pública, p. 28.

${ }^{55}$ Direito Administrativo Moderno, p. 120.
} 
mas a uma rede de princípios que asseguram a congruência da decisão e ao fim do interesse geral $^{56}$.

Sublinha Edmir Netto de Araújo ${ }^{57}$ que,

Os limites da ação voluntária do agente são, portanto, o ordenamento jurídico (limites traçados pela lei para o caso concreto), a competência (do agente e do órgão), a finalidade (do interesse público concreto) e a forma (prescrita ou permitida por lei): ultrapassar esses limites significa arbitrariedade, ao contrário da discricionariedade, que é a liberdade de movimentação do agente público, nos atos não vinculados, dentro de tais limites.

Alguns argumentos procuram explicar a existência dessa zona com um pouco mais de liberdade, dentre eles, uma justificativa exposta pela doutrina diz respeito à complexidade do Estado contemporâneo e à amplitude de funções desempenhadas pela administração, o que impossibilitaria disciplinar, por lei, todos os aspectos da vida social em que a administração atua. Seria necessário deixar certa margem de flexibilidade à administração para que, em função da situação concreta, pudesse ela adotar as medidas mais adequadas ao atingimento do interesse público.

A própria separação e o equilíbrio dos poderes daria suporte para que o controle judicial incidisse apenas em relação à observância da lei, de modo estrito. Haveria quase que um impedimento à ingerência nas decisões administrativas no que diz respeito à conveniência e oportunidade.

Régis de Oliveira assinala que, "a doutrina justifica a existência do poder discricionário pela impossibilidade lógica e material de o legislador prever toda a gama infinita de circunstâncias que podem apresentar-se no mundo empírico. As realidades são tão variáveis que seria praticamente impossível ao legislador prever todas as hipóteses de ocorrência no mundo fático" ${ }^{\text {58 }}$. Além da impossibilidade lógica e material, Régis de Oliveira, menciona a impossibilidade jurídica, já que se fosse possível prever, "na atividade legiferante, todas as ocorrências possíveis, então teríamos, pura e simplesmente, a substituição de um órgão do poder por outro, ou seja, teríamos a supressão do órgão

\footnotetext{
${ }^{56}$ Ibidem, p. 122.

${ }^{57}$ Curso de Direito Administrativo, 6 ${ }^{\mathrm{a}}$. ed., p. 511.

${ }^{58}$ Ato Administrativo, p. 68 .
} 
administrativo ou executivo. Este não passaria de mero cumpridor de ordens emanadas, concretamente, do Poder Legislativo"

Edmir Netto de Araújo $^{60}$ ressalta que:

O vocábulo, utilizado indiscriminadamente, leva a premissas e conclusões imprecisas e confusas, e a jurisprudência não tem ajudado muito no combate a tal imprecisão científica, no exame dos casos concretos, ora ampliando, ora restringindo o conceito. Há, mesmo, uma tendência auto restritiva de nossos Tribunais ao caracterizar a discricionariedade, além da imposta pelo direito positivo."

\subsection{Noções sobre discricionariedade}

Maria Sylvia Zanella Di Pietro conceitua discricionariedade como sendo "a faculdade que a lei confere à Administração para apreciar o caso concreto, segundo critérios de oportunidade e conveniência, e escolher uma dentre duas ou mais soluções, todas válidas perante o direito" ${ }^{\circ 1}$.

Para Lucia Valle Figueiredo discricionariedade "consiste na competência-dever de o administrador, no caso concreto, após a interpretação, valorar, dentro de critério de razoabilidade e afastado de seus próprios 'standards' ou ideologias - portanto, dentro de critério da razoabilidade geral - dos princípios e valores do ordenamento, qual a melhor maneira de concretizar a utilidade pública postulada pela norma". ${ }^{2}$

Celso Antônio Bandeira de Mello ao conceituar discricionariedade, entende que ela abrange também a categoria dos conceitos indeterminados ${ }^{63}$ :

Discricionariedade é a margem de "liberdade" que remanesça ao administrador para eleger, segundo critérios consistentes de razoabilidade, um, dentre pelo menos dois comportamentos, cabíveis perante cada caso concreto, a fim de cumprir o dever de adotar a solução mais adequada à satisfação da finalidade legal, quando, por força da fluidez das expressões da

\footnotetext{
${ }^{59}$ Ibidem, p. 68.

${ }^{60}$ Curso de Direito Administrativo, 6 ${ }^{\mathrm{a}}$. ed., p. 1289.

${ }^{61}$ Discricionariedade Administrativa na Constituição de 1988, ed, 2012, p. 62.

${ }^{62}$ Curso de Direito Administrativo, p. 203.

${ }^{63} \mathrm{O}$ "Poder" Discricionário, p. 27/28.
} 
lei ou da liberdade conferida no mandamento, dela não se possa extrair objetivamente uma solução unívoca para a situação vertente."

"A noção de discricionariedade não se adscreve apenas ao campo das opções administrativas efetuadas com base em critérios de conveniência e oportunidade - tema concernente ao mérito do ato administrativo. Certamente o compreende, mas não se cinge a ele, pois também envolve o tema da intelecção dos conceitos vagos. Resulta, pois, que são incorretos por insuficientes - os conceitos de discricionariedade que a caracterizam unicamente em função do tema do 'mérito' do ato administrativo, isto é, da 'conveniência ou oportunidade do ato"".

\subsection{Noção de mérito administrativo}

Odete Medauar ${ }^{65}$ destaca que corresponde à noção de mérito administrativo aquela margem livre sobre a qual incide a escolha inerente à discricionariedade.

Celso Antônio conceitua mérito do ato como sendo,

o campo de liberdade suposto na lei e que efetivamente venha a remanescer no caso concreto, para que o administrador, segundo critérios de conveniência e oportunidade, decida-se entre duas ou mais soluções admissíveis perante a situação vertente, tendo em vista o exato atendimento da finalidade legal, ante a impossibilidade de ser objetivamente identificada qual delas seria a única adequada ${ }^{66}$.

Assinala o mesmo autor que “o 'mérito' do ato administrativo não pode ser mais que o círculo de liberdade indispensável para avaliar, no caso concreto, o que é conveniente e oportuno à luz do escopo da lei. Nunca será liberdade para decidir em dissonância com este escopo". 67

A doutrina acerca do mérito do ato administrativo desenvolveu-se no direito italiano. Fala-se em princípio da oportunidade e conveniência, no direito francês e alemão. No direito brasileiro, Seabra Fagundes em seu livro "O controle dos atos administrativos pelo Poder Judiciário" relaciona mérito com discricionariedade e afasta a possibilidade de controle judicial. Compreende ele que a discricionariedade administrativa expressa-se pelo mérito do ato administrativo e, por mérito, entende o "sentido político" do ato.

\footnotetext{
${ }^{64}$ Celso Antônio Bandeira de Mello. Curso de Direito Administrativo, 27a . ed., p. 973.

${ }^{65}$ Direito administrativo moderno, p. 123.

${ }^{66}$ Curso de Direito Administrativo, 27 ${ }^{\mathrm{a}}$. ed., p. 965.

${ }^{67}$ Discricionariedade e controle jurisdicional, p. 82
} 
O mérito está no sentido político do ato administrativo. É o sentido dele em função das normas da boa administração. Ou, noutras palavras: é o seu sentido como procedimento que atende ao interesse público, $e$, ao mesmo tempo, o ajusta aos interesses privados, que toda medida administrativa tem de levar em conta. Por isso, exprime um juízo comparativo.

Compreende os aspectos, nem sempre de fácil percepção, atinentes ao acerto, à justiça, utilidade, equidade, razoabilidade, moralidade etc. de cada procedimento administrativo.

Esses aspectos, muitos autores os resumem no binômio: oportunidade e conveniência. Envolvem eles interesses e não direitos. Ao Judiciário não se submetem os interesses, que o ato administrativo contrarie, mas apenas os direitos individuais, acaso feridos por ele. O mérito é de atribuição exclusiva do Poder Executivo, e o Poder Judiciário, nele penetrando, faria obra de legislador, violando, dessarte, o princípio de separação e independência dos poderes. ${ }^{68}$

Para José Cretella Júnior ${ }^{69}$,

o mérito relaciona-se com a intimidade do ato administrativo, concerne ao seu valor intrínseco, à sua valoração sob critérios comparativos. Sob o ângulo do merecimento, não se diz se o ato é ilegal ou legal, senão que "é ou não é o que devia ser", que é bom ou mau, que é pior ou melhor do que outro. Por isto é que os administrativistas o conceituam, uniformemente, como o aspecto do ato administrativo relativo à conveniência, à oportunidade, à utilidade intrínseca do ato, à sua justiça, à fidelidade aos princípios da boa gestão, à obtenção dos desígnios genéricos e específicos, inspiradores da atividade estatal". Ainda para esse autor, "o mérito do ato administrativo, a valoração do fato, resumida no binômio oportunidadeconveniência, continua a ser campo privativo da Administração, insuscetível de reexame pelo Poder Judiciário".

Durante muito tempo, a doutrina e a jurisprudência vedaram o controle do mérito pelo judiciário; só mais recentemente, tanto doutrina como jurisprudência têm se insurgido contra a insindicabilidade do mérito pelo Poder Judiciário.

Assinala Maria Sylvia Zanella Di Pietro ${ }^{70}$, acerca dessa ideia da insindicabilidade do mérito no direito brasileiro, afirmando que

"Na realidade, é possivel que o direito brasileiro, ao inspirar-se no direito italiano com a afirmação de que o Judiciário não pode controlar o mérito do ato administrativo, tenha deixado de levar em consideração que naquele país existe a jurisdição administrativa, que tem competência para controlar o mérito, Quem não pode efetuar esse controle é a jurisdição comum. .... Quer-se dizer, com isto, que se no direito brasileiro não existe a

\footnotetext{
${ }^{68} \mathrm{O}$ controle dos atos administrativos pelo Poder Judicial, p. 149/150.

${ }^{69}$ Direito Administrativo Brasileiro, p. 294.

70 . Discricionariedade Administrativa na Constituição de 1988, $3^{\text {a }}$. ed., pág. 134.
} 
dualidade de jurisdição, as competência que seriam de uma jurisdição administrativa têm que se concentrar no Poder Judiciário, no sistema de unidade de jurisdição, que decorre do artigo $5^{\circ}$., XXXV, da Constituição Federal. A conclusão única possível, é a de que o Judiciário pode examinar $o$ mérito do ato administrativo. No entanto, o que não é possível é o Judiciário substituir a decisão discricionária adotada validamente. Ele está limitado pela legalidade em sentido amplo, abrangendo não só os atos normativos, como também os princípios e valores adotados de forma expressa ou implícita na Constituição".

Para Héctor Escola, o controle sobre o mérito e oportunidade cabe tanto sobre os atos vinculados (reglados) como sobre os atos discrecionais da administração. ${ }^{71}$ Para o autor, " $L a$ actividad administrativa exige esa doble condición de legalidade y oportunidade o conveniência, y um control limitado a uno solo de esos aspectos seria incompleto, pusto que si no puede aceptarse que existan actos convenientes que sean ilegítimos, tampoco interessa, em verdade, que se produzan actos legítimos, pero inconvenientes o inoportunos"

Não há como negar que o Judiciário tem exercido, quando chamado a atuar, um controle mais elastecido sobre os atos da administração. Algumas teorias foram concebidas para justificar uma maior sindicabilidade sobre os aspectos que até então eram considerados como de mérito e, portanto, não passíveis de controle judicial. A teoria do desvio de poder, a teoria dos motivos determinantes, a teoria dos conceitos jurídicos indeterminados, a constitucionalização dos princípios da Administração Pública; que buscaram limitar a atuação discricionária, possibilitando a ampliação do controle judicial sobre os atos discricionários. Pode-se dizer que houve uma sensível redução da abrangência do mérito administrativo, já que aspectos antes considerados de mérito e, portanto, fora do controle judicial, são agora vistos como de legalidade ${ }^{72}$. Isto não quer dizer que se tenha subtraído da Administração a "liberdade" de poder escolher a melhor solução para o caso concreto que lhe é posto, o que se quer dizer é que essa escolha não é inteiramente livre, ela está delimitada pela legalidade, pela razoabilidade, pelo interesse público.

\footnotetext{
71 "El control sobre el mérito y la oportunidade cabe igualmente tanto sobre los actos reglados como sobre los actos discrecionales de la administración, aun cuandotodas las irregularidades que pueden afectar al acto administrativo y justificar uma acción de control deben resultar y estar referidas, explicitamente o implicitamente, a las normas jurídicas aplicables em cada caso, de manera que el problema será siempre, a ala postre, uma cuestión de legitimidade, de valoración lógico-jurídica. ... La actividad administrativa exige esa doble condición de legalidade y oportunidade o conveniência, y um control limitado a uno solo de esos aspectos seria incompleto, pusto que si no puede aceptarse que existan actos convenientes que sean ilegítimos, tampoco interessa, em verdade, que se produzan actos legítimos, pero inconvenientes o inoportunos". Héctor Jorge Escola. Compendio de Derecho Administrativo, v. II, p. 1169.

${ }^{72}$ Discricionariedade Administrativa na Constituição de 1988, $3^{\text {a }}$. ed., pág. 135.
} 
Assenta Luis Manuel Fonseca Pires, em sua tese de doutoramento, que no atual estágio da ciência jurídica não há mais necessidade de se invocar essa expressão "mérito administrativo'. Justifica seu entendimento, em primeiro lugar, por não existir na doutrina e na jurisprudência uma definição precisa do mérito, afirmando que tanto coincide com objeto (a conveniência como sinônimo de objeto), ora com o motivo (a oportunidade como motivo), ora com conteúdo, ora com o momento da prática do ato. Em segundo lugar, porque sob esse rótulo do 'mérito' há decisões judiciais que recusam a legitimidade do controle judicial. "a Administração escusa-se perante o Judiciário de que a atividade impugnada não pode ser conhecida por este Poder porque se trata de assunto relacionado ao indefinido e impreciso "mérito"”. Para ele, o próprio Judiciário adianta-se para se omitirem controlar a legitimidade da atividade administrativa sob o mesmo argumento.

\section{Controle}

Marçal Justen, citando Fábio Konder Comparato, destaca que o vocábulo controle comporta dois sentidos diversos. Pode-se falar em controle-fiscalização para indicar a tarefa de acompanhar e fiscalizar conduta alheia, verificando o cumprimento dos requisitos necessários e a realização dos fins adequados. Podendo haver também o controle-orientação, ou seja, a possibilidade de determinar o conteúdo da conduta alheia, escolhendo os fins que o terceiro realizará e o modo pelo qual se desenvolverá. ${ }^{73}$

Tomado numa acepção restrita, Odete Medauar $^{74}$ conceitua controle como sendo a verificação de conformidade da atuação da Administração Pública a um determinado cânone,

Em acepção restrita considera-se controle a atividade que possibilita a edição de ato ou medida pelo agente controlador em decorrência do confronto que realizou. Daí o conceito seguinte: Controle da Administração Pública é a verificação da conformidade da atuação desta a um cânone, possibilitando ao agente controlador a adoção de medida ou proposta em decorrência do juízo formado.

Como destacado em tópico anterior, o Estado, por meio da Administração Pública, passou a exercer uma gama enorme de atribuições, o que passou a exigir uma estrutura de

\footnotetext{
${ }^{73}$ Curso de Direito Administrativo, p. 1111, apud Comparato; Salomão Filho. O Poder de controle na sociedade anônima.

${ }^{74}$ Controle da Administração Pública, p. 30.
} 
controle eficiente, no sentido de buscar garantir uma boa administração, baseada nos cânones legais.

Uma estrutura de controle exercida de forma eficiente constitui-se no pressuposto de uma boa administração.

\subsection{Controle da Administração - objetivo}

Como afirma Manuel Gonçalves Ferreira Filho, repugna o pensamento político contemporâneo a ilimitação do poder. A concepção é a de que o poder deve ser limitado, mesmo o legítimo. ${ }^{75}$

A busca por formas de controlar de maneira efetiva a administração não é algo novo. No que toca à fiscalização dos gastos públicos, na antiga Grécia, em Atenas, já se tem notícia do exercício do controle das contas públicas. ${ }^{76}$

A Declaração dos Direitos do Homem e do Cidadão, de 1789, continha, em seu artigo 15, em relação à administração, que é direito da sociedade pedir conta a todo agente público $^{77}$, disposição essa que remete à ideia de controlar, fiscalizar.

O controle não é um fim em si mesmo, quais seriam então os objetivos primários que um controle eficiente persegue?

Héctor Jorge Escola, ao responder à questão sobre qual a finalidade do controle administrativo e qual o objeto que se tende a alcançar, afirma que em um exame superficial a resposta pareceria indicar que o controle administrativo tem por objeto proteger e garantir os direitos subjetivos dos administrados, mas, em uma análise mais detida, seria possível comprovar que o controle administrativo, tem por objetivo essencial manter a juridicidade da atividade administrativa, já que este seria o resultado da ação de controle. ${ }^{78}$

\footnotetext{
${ }^{75}$ Curso de Direito Constitucional, p. 134.

76، A fiscalização dos gastos públicos sempre foi preocupação do direito político. Ela já remonta à velha Grécia, visto que em Atenas já existia um tribunal constituído de dez oficiais, eleitos pelas Eclesias, que tomavam as contas aos arcontes, estrategos, embaixadores, sacerdotes e a todos que manipulavam com dinheiro público." Pinto Ferreira, v. 3, p. 394/5.

${ }^{77}$ Odete Medauar, Direito Administrativo Moderno, p. 409.

78 "Um examen sólo superficial de esta cuestión pareceria indicar que el control administrativo tiene por principal objeto proteger e garantizar los derechos subjetivos de los administrados, ya sea que éstos tengan um interés directo o meramente indirecto. ....Sin embargo, um análisis más detenido permite comprovar que el control administrativo, em realidade, tiene por objeto essencial em mantenimiento de la juridicidade de la
} 
Nos dias de hoje, a ideia de controle esteja intimamente relacionada ao combate à corrupção e desvio de recursos públicos, mostrando-se, cada dia mais importante e necessária, uma efetiva estrutura de controle.

Sublinha Floriano de Azevedo Marques Neto ${ }^{79}$, entretanto, que,

O controle não se presta apenas para evitar o desvio de bens ou recursos públicos. O controle deve envolver também a verificação de que o poder atribuído ao Estado está sendo manejado eficientemente para cumprir as finalidades que justificam e legitimam a sua atribuição ao agente público ou se o sacrifício de direitos individuais inerente à ação estatal está correspondente ao proveito efetivo auferível pela coletividade. $\mathrm{O}$ controle dos bens e recursos públicos é importante, mas ele se cinge à aferição da regularidade do exercício das atividades-meio da Administração. Antes ou independente dele há que se controlar o adequado uso do poder extroverso e o resultado do manejo deste poder.

Além de ser um instrumento para o aperfeiçoamento da Administração na busca da eficiência e efetividade ${ }^{80}$, o controle deve ter um viés pragmático ou consequencialista, no sentido de que o controle deve ser responsivo ${ }^{81}$, assinala Floriano de Azevedo Marques Neto. Para o autor, um sistema de controle que só pune, invalida e impede não será um controle conforme os cânones do Estado Democrático de Direito.

A presunção de que o controle valha por si só, como se a mera existência de estruturas de controle seja suficiente para a Boa Administração trai uma via formalista do controle. A Administração Pública somente é eficiente se além de não desperdiçar recursos públicos (evitando o desvio ou o desperdício) ela logra atender às necessidades coletivas que correspondem à finalidade do agir administrativo. ${ }^{82}$

O mesmo Professor assinala que é possível identificar uma tripla dimensão do instituto do controle, que se volta ao poder, aos meios e aos objetivos. ${ }^{83}$

actividad administrativa, ya que éste es, evidentemente, el resultado último de la acción de control."Héctor Jorge Escola. Compendio de Derecho Administrativo, v. II, p. 1158/9.

${ }^{79}$ Os Grandes desafios do controle da Administração Pública, in Nova Organização Administrativa Brasileira, Coordenador Paulo Modesto, p; 206.

${ }^{80}$ Floriano de Azevedo Marques Neto. Os grandes desafios do controle da Administração Pública, p. 207.

${ }^{81}$ No sentido de que qualquer órgão ou agente incumbido do controle deve sempre avaliar as consequências da medida de controle antes de adotá-la. Ibidem, p. 207.

${ }^{82}$ Ibidem p. 207.

${ }^{83}$ Ibidem p. 206. 
O controle do poder busca garantir a liberdade e proteger os indivíduos contra o risco de exercício arbitrário do poder político, por meio de um plexo de regras e princípios destinados a limitar o poder estatal. O controle dos meios objetiva a racionalização da atividade administrativa, "de maneira a que ela seja orientada pela economicidade e probidade" ${ }^{\nexists 4}$. Esse controle deve orientar-se pela otimização da gestão do patrimônio público, o que inclui o controle do desvio de finalidade na gestão da coisa pública. O controle dos objetivos volta-se a assegurar a manutenção e a estabilidade das políticas públicas, assim como assegurar também um agir administrativo voltado a prontamente suprir as demandas dos administrados.

No controle efetivo da Administração Pública, Floriano de Azevedo Marques Neto ${ }^{85}$ assinala os objetivos que o controle deve perseguir, sendo o primeiro deles, a defesa do patrimônio público. O Estado tem o dever de defesa de todos os bens, direitos e receitas que integram o seu patrimônio. Afirma o autor que a palavra dever é utilizada em razão da própria relação entre propriedade estatal e a necessidade de cumprimento permanente da função social, que é condição de legitimação da existência de patrimônio público.

O segundo objetivo identificado é a adequada aplicação dos recursos públicos. O Estado tem o dever de se preocupar com a gestão orçamentária, de forma a alocar os recursos nas atividades que sejam prioritárias e necessárias ao bom exercício das atividades. Com a escassez de recursos, cada vez se torna mais importante gerenciar com eficiência. “Assim é que a adequada aplicação dos recursos públicos se relaciona não apenas com a gestão orçamentária, como também com responsabilidade civil, economicidade (eficiência alocativa) e probidade" ${ }^{\prime \prime 6}$.

O cumprimento das finalidades da atuação administrativa é indicado como terceiro objetivo visado pelo controle. Sublinha o autor que é importante que o controle seja exercido sobre políticas públicas e se faça de modo a coibir o abuso e o desvio de poder e em prol da implementação de direitos fundamentais previstos na Lei Magna. Destaca, ainda, que nesse terceiro objetivo há que ser feito também um controle da eficiência administrativa.

Por fim, o quarto objetivo citado é a adstrição à legalidade. Tendo em conta que a base de toda atuação administrativa é a lei, o controle objetiva, primeiramente, a conformação

\footnotetext{
${ }^{84}$ Ibidem, p. 206.

${ }^{85}$ Os grandes desafios do controle da Administração Pública, in Nova Organização Administrativa Brasileira, coord. Paulo Modesto, p. 210/211.

${ }^{86}$ Ibidem, p. 210/211.
} 
do ato ou do procedimento com a norma que o abriga. Quando se fala em legalidade ou legitimidade deve-se entender não só o atendimento de normas legisladas como também os preceitos da Administração pertinentes ao ato controlado.

\subsection{Controle Judicial da Administração - controle externo}

O controle da Administração realizado por órgão, ente ou instituição exterior à estrutura da Administração é chamado de controle externo. O controle judicial da administração está inserido no âmbito desse chamado controle externo.

Em razão da inércia da jurisdição, o controle judicial é sempre exercido por provocação da parte e é feito, em regra, "a posteriori”. Esse controle se realiza por meio do ajuizamento de ações, que observam procedimentos formais, com garantias às partes, tais como: juiz natural, imparcialidade, contraditório, ampla defesa, dentre outras.

A Constituição da República adotou, em seu artigo $5^{\circ}$, inciso XXXV, o princípio da inafastabilidade do controle pelo poder judiciário "a lei não excluirá da apreciação do poder judiciário lesão ou ameaça de direito". José Afonso da Silva o nomina também de "princípio da proteção judiciária", afirmando que esse princípio se constitui na principal garantia dos direitos subjetivos e que ele se fundamenta no princípio da separação de poderes, reconhecido pela doutrina como garantia das garantias constitucionais. ${ }^{87}$

O controle judicial constitui, juntamente com o princípio da legalidade, um dos pilares em que repousa o Estado de Direito. Que valor teria sujeitar-se a Administração Pública à lei se não houvesse a possibilidade de controlar os seus atos por um órgão dotado de garantias de imparcialidade, inclusive com poderes de apreciar e invalidar os atos ilícitos praticados? ${ }^{88}$

\subsection{Sistemas de controle judicial}

Nos diversos ordenamentos jurídicos, o controle judicial da Administração, se faz por dois sistemas básicos de controle ${ }^{89}$ : o sistema de jurisdição dupla, denominado também de

\footnotetext{
${ }^{87}$ José Afonso da Silva, Curso de Direito Constitucional Positivo, p. 429.

${ }^{88}$ Maria Sylvia Zanella Di Pietro, Direito Administrativo, p. 747.

${ }^{89}$ Héctor Escola cita uma terceira modalidade de controle a que ele chama de intermediário ou misto: "Los sistemas intermédios o mixtos, a su vez, se fundan em el principio de que los tribunales judiciales entienden em
} 
dualidade de jurisdição, contencioso administrativo, sistema francês ${ }^{90}$, justiça administrativa ou sistema de jurisdição administrativa; e o sistema de jurisdição una, intitulado também unidade de jurisdição, sistema de jurisdição ordinária ou sistema de judicial. ${ }^{91}$

A expressão contencioso administrativo é usada, ao menos, em dois sentidos. No primeiro deles, de modo um pouco mais amplo, é utilizada para nominar qualquer tipo de conflito que tramite na via administrativa. Assinala José dos Santos Carvalho Filho que, mesmo nos países que não adotam o sistema em foco, existe o contencioso administrativo, já que é possível aos administrados reclamarem da administração junto aos seus próprios órgãos. Segundo ele, os recursos de reclamação e de representação são um exemplo, vez que tramitam na via administrativa. ${ }^{92}$

O segundo sentido, mais restrito, é utilizado para denominar apenas a jurisdição administrativa, ou seja, a ordem jurisdicional específica destinada a resolver os litígios em face da Administração, num modelo que separa a jurisdição comum da jurisdição administrativa, a exemplo do modelo Francês.

\subsubsection{Contencioso administrativo}

O sistema do contencioso administrativo caracteriza-se por ser um modelo no qual convivem duas ordens de jurisdição; de um lado, uma jurisdição administrativa, destinada a julgar litígios que envolvam a Administração Pública e, de outro, uma jurisdição ordinária.

Esse modelo, que foi adotado pela França, Alemanha, Portugal, dentre outros países, é composto por juízes e tribunais administrativos. A organização dessa Jurisdição Administrativa é complexa e se compõe de várias Cortes e Tribunais Administrativos,

\footnotetext{
las controvérsias relativas a la justicia que podríamos llamar de derecho privado, aun cuando sea parte em ella la administración pública, obrando como persona de derecho privado. Pero cuando se trata de actos cumplidos por la administración, actuando como tal y em ejercicio de las potestades que le son inerentes, los tribunales judiciales no tienen competência para intervenir em las causas que se susciten, que son remitidas al conocimiento y decisión de tribunales especiales. ..De tal suerte, em los sistemas intermédios o mixtos los litígios em que es parte la administración pública se distribuyen entre órganos judiciales, y entre órganos que tienen funciones jurisdicionales, pero que no integram el Poder Judicial." Compendio de Derecho Administrativo, p. 1222/3.

90 José dos Santos Carvalho Filho. Manual de Direito Administrativo, p. 931.

91 Odete Medauar, Direito Administrativo Moderno, p. 428-9

92 José dos Santos Carvalho Filho. Manual de Direito Administrativo, p. 931.
} 
encabeçados por um órgão supremo próprio, denominado, via de regra, de Conselho de Estado ou Corte Suprema Administrativa.

Na França, o órgão supremo é o Conselho de Estado (Conseil d’État). Em caso de necessidade de dirimir conflito de atribuição entre as duas jurisdições, a controvérsia é decidida por um Tribunal, chamado de Tribunal de Conflitos, criado fundamentalmente para esse fim. ${ }^{93} \mathrm{O}$ Tribunal de Conflitos é composto por membros da jurisdição comum (Corte de Cassação) e da jurisdição administrativa (Conselho de Estado), de forma paritária.

Em outros países, outra fórmula foi estabelecida para essa solução de conflitos. Na Espanha e Suíça a solução do conflito cabe à Corte Suprema do Poder Judiciário, ao qual as jurisdições administrativas subordinam-se. Na Espanha há ainda, no âmbito do Tribunal Supremo, uma Câmara de Conflitos encarregada da questão. Outros, ainda, como é o caso da Áustria (art. 138 da Constituição da Áustria de 1920), atribuem à Corte Constitucional a resolução dos conflitos. ${ }^{94}$

Explica Odete Medauar que adotam a jurisdição dupla, atualmente: França (de onde se originou), Alemanha, Suécia, Portugal, Grécia, Áustria, Luxemburgo, Polônia; na América do Sul, Colômbia (dotada de um novo Código, reunindo preceitos do processo administrativo e do contencioso administrativo - Lei 1.437, de 18.01.2011, com início de eficácia em 02.07.2012). ${ }^{95}$

O modelo do contencioso administrativo apresenta jurisdição e competência sobre alguns litígios específicos, em que, necessariamente, uma das partes é sempre o Poder Público, nunca, entre particulares apenas.

Assinala José dos Santos Carvalho Filho que compete ao modelo em questão julgar causas que visem à invalidação e à interpretação de atos administrativos, bem como, aquelas em que o interessado requer a restauração da legalidade, em razão de ofensa a direito decorrente de conduta administrativa, e, ainda, julgar recursos administrativos que versem sobre excesso ou desvio de poder. ${ }^{96}$

Em ambas as jurisdições, as decisões são cobertas pelo manto da coisa julgada, de modo que uma causa decidida em qualquer delas não mais pode ser reapreciada.

\footnotetext{
${ }^{93}$ Ibidem, p. 932.

${ }^{94}$ Odete Medauar. Controle da Administração Pública, p. 197.

${ }^{95}$ Controle Jurisdicional da Administração, p. 193.

${ }^{96}$ Ibidem, p. 931.
} 
Destaca Odete Medauar a existência de um sistema misto, no qual se incluem os ordenamentos em que os litígios, quer administrativos, quer ordinários, são decididos por um único tribunal que representa o último grau de jurisdição para ambos; isso sem que se leve em consideração a existência de um Tribunal específico para litígios de natureza constitucional. Segundo a autora, esse sistema misto vigora na Hungria, Romênia, Eslovênia e Estônia, por exemplo. ${ }^{97}$

\subsubsection{Unidade de jurisdição}

O sistema da unidade de jurisdição, também conhecido como sistema do monopólio de jurisdição ou sistema inglês; como o próprio nome diz, todos os litígios, sejam eles administrativos ou privados, estão sujeitos à apreciação da justiça comum, embora sejam admitidos órgãos ou varas especializadas, que estão inseridas em uma única ordem de jurisdição. Adotam esse sistema, dentre outros, os Estados Unidos, Irlanda, Argentina e Brasil.

Nesse sistema, apenas o Poder Judiciário exerce a função jurisdicional e profere decisões com caráter de definitividade. A Administração Pública, em nenhum momento exerce função jurisdicional, de modo que não há coisa julgada e seus atos sempre poderão ser reapreciados pelo Poder Judiciário.

$\mathrm{O}$ artigo $5^{\circ}$, inciso XXXV, da Constituição do Brasil (a lei não excluirá da apreciação do Poder Judiciário lesão ou ameaça a direito) é o fundamento para a adoção do modelo de jurisdição una.

\subsection{Controle Judicial - amplitude}

Uma das questões que mais tem suscitado controvérsias acerca do tema do controle jurisdicional da administração diz respeito ao alcance da atuação do judiciário, ou seja, a amplitude do controle exercido pelo Poder Judiciário.

\footnotetext{
${ }^{97}$ Controle da Administração Pública, p. 198-9.
} 
Assinala Odete Medauar que é possível identificar-se, ao menos, dois posicionamentos no que diz respeito à amplitude desse controle. De um lado, um posicionamento que se mostra favorável ao controle restrito do Poder Judiciário sobre a atividade da Administração, de modo que o controle se atenha apenas à questão da legalidade, entendida essa, de modo restrito, no sentido de atuação conforme a Constituição e a lei. ${ }^{98}$

Alguns argumentos são utilizados para fundamentar essa orientação. O primeiro deles é o princípio da separação de poderes, que é invocada como barreira à ingerência do Poder Judiciário em atividades típicas do Poder Executivo, de modo que, o âmbito de controle do judiciário estaria circunscrito à legalidade em sentido estrito. $\mathrm{O}$ outro argumento, refere-se ao fato de que os integrantes do Poder Judiciário, por serem desprovidos de mandato eletivo, não teriam legitimidade para reapreciar aspectos relacionados ao interesse público.

Por essa corrente restritiva, o controle do ato administrativo ficaria circunscrito à matéria relativa à competência, forma e licitude do objeto, além do que, o ato de governo estaria fora do controle.

O outro entendimento está vinculado a um controle mais amplo da Administração. Como justificativa utiliza, nada menos, que o próprio princípio da separação de poderes, argumentando que "se o poder detém o poder, se ao Poder Judiciário cabe a jurisdição, é da lógica da separação de poderes o controle sobre a administração, sem que se possa cogitar de ingerência indevida. Para isso os ordenamentos garantem a independência dos juízes." $" 99$

Vanice do Vale acentua que o "signo de neutralidade" é o pressuposto que legitima a atuação dos órgãos jurisdicionais, que se manifesta de duas formas: 1) no modo de atuação dos órgãos jurisdicionais, caracterizado pelo uso de parâmetro técnico para o desenvolvimento de sua função típica; 2) na blindagem institucional, viabilizado por garantias e imunidades atribuídas àquela estrutura de poder político. ${ }^{100}$

Sob a vigência da Constituição de 1946, pôde-se observar importante ampliação do controle jurisdicional sobre o ato administrativo, em especial, por força do posicionamento de Seabra Fagundes, por ocasião do voto por ele proferido na apelação n ${ }^{\circ} .1 .422$, do Tribunal de Justiça do Rio Grande do Norte, cuja análise será feita mais adiante. Representou avanço na ampliação do controle jurisdicional além da competência e forma do ato administrativo, para

\footnotetext{
98 Ibidem, p. 209.

99 Ibidem, p. 210.

100 Audiências Públicas e Ativismo, p. 18.
} 
adentrar nos motivos e fim do ato, como integrantes da legalidade e não da discricionariedade e mérito. ${ }^{101}$

A Constituição de 1988 atribuiu ao Poder Judiciário uma série de garantias e prerrogativas que se traduzem em autonomia funcional, administrativa e financeira, além de assegurar aos magistrados a vitaliciedade, inamovibilidade e irredutibilidade de vencimentos, que provocam uma liberdade abstrata ao Judiciário para que possa exercer o controle de juridicidade dos atos praticados pelas demais esferas do poder. ${ }^{102}$

As garantias conferidas aos membros do Poder Judiciário, de acordo com Alexandre de Moraes $^{103}$, conferem à instituição a necessária independência para o exercício da jurisdição. Essas garantias ou esses predicamentos da magistratura não devem ser entendidos como privilégios dos magistrados, mas sim como meio de assegurar o seu livre desempenho, de molde a revelar a independência e autonomia do judiciário. ${ }^{104}$

Embora possa ainda ser observada, em alguns segmentos da doutrina certa reticência em aceitar uma ampliação da esfera do controle judicial, já é possível verificar um alargamento dessa esfera de discricionariedade justiciável ${ }^{105}$, decorrente do reconhecimento da eficácia normativa dos princípios, que vinculam a atuação discricionária da administração, como se verá quando da análise dos acórdãos.

4.4.1. Controle sobre os requisitos vinculados - competência, forma e finalidade

Inicialmente, como anteriormente referido, com a aceitação da dicotomia entre atos vinculados e atos discricionários, passou-se a admitir que o Poder Judiciário pudesse fazer o

\footnotetext{
${ }^{101}$ Odete Medauar. Direito Administrativo Moderno, p. 432.

102 Ibidem, p. 19.

${ }^{103}$ Direito Constitucional, p. 347.

104 "Todas as garantias, ou seja, Autonomia funcional, administrativa e independência; independência; vitaliciedade; inamovibilidade; irredutibilidade de vencimento, imparcialiadade.

"Todas essas garantias, portanto, são imprescindíveis ao exercício da democracia, à perpetuidade da Separação de Poderes e ao respeito aos direitos fundamentais, configurando suas ausências, supressões ou mesmo reduções, obstáculos inconstitucionais ao Poder Judiciário, no exercício de seu mister constitucional, permitindo que sofra pressões dos demais Poderes do Estado e dificultando o controle da legalidade dos atos políticos do próprio Estado, que causem lesão a direitos individuais e coletivos." Alexandre de Moraes. Direito Constitucional, p. 347.

105 Expressão utilizada por Germana de Oliveira Marques, in Controle Jurisdicional da Administração Pública, p. 28.
} 
exame apenas da legalidade do ato, ou seja, das formalidades extrínsecas dos atos discricionários. Era vedado ao judiciário ingressar no exame do mérito do ato discricionário, concebido como o binômio conveniência-oportunidade.

Dá bem o exemplo dessa concepção as palavras de Caio Tácito, para quem, " $a$ oportunidade do ato poderá, em certos casos, ser reexaminada pela própria Administração; em nenhuma hipótese poderá ser apreciada pelo Poder Judiciário, que, nessa matéria, está impedido de se manifestar",106.

$\mathrm{O}$ entendimento que prevalecia era no sentido de que a competência, a forma e a finalidade compunham a tríade dos elementos vinculados e, portanto, suscetíveis de controle jurisdicional. O motivo e o objeto eram elementos cuja apreciação pelo Poder Judiciário encontrava sérios limitadores.

O magistrado, na atividade de controle, diante de um ato discricionário deveria, necessariamente, ater-se a aspectos meramente formais. Isso quer dizer que as razões pelas quais uma ou outra medida houvesse sido adotada, refugiria ao exame próprio do Poder Judiciário, por fazer parte da discricionariedade outorgada à autoridade administrativa, consubstanciando-se, tais razões, no próprio mérito do ato. Considerava-se que tal limitação seria naturalmente imposta pelo princípio da separação de poderes, segundo o qual um poder não deve interferir na atuação do outro, mantendo-se dentro dos seus limites. ${ }^{107}$

Seabra Fagundes também sintetizou bem essa concepção,

“o mérito está no sentido politico do ato administrativo. É o sentido dele em função das normas da boa administração, ou, noutras palavras, é o seu sentido como procedimento que atende ao interesse público e, ao mesmo tempo, o ajusta aos interesses privados, que toda medida administrativa tem de levar em conta. (...) O mérito é de atribuição exclusiva do Poder Executivo, e o Poder Judiciário, nele penetrando, faria obra de administrador, violando, destarte, o princípio da separação e independência dos poderes ${ }^{108}$.

A posição de Caio Tácito acerca dessa questão é bastante elucidativa no que tange ao entendimento acerca da insindicabilidade do ato discricionário,

A Administração encontra, assim, no processo de sua realização, um campo de livre desenvolvimento, no qual lhe é facultada a seleção da maneira de

\footnotetext{
${ }^{106}$ Poder Vinculado e Poder Discricionário, in xxx, p. 316.

${ }^{107}$ Gustavo Binenbojn. Uma teoria do Direito Administrativo, p. 202/203.

${ }^{108}$ Miguel Seabra Fagundes, O Controle dos Atos Administrativos pelo poder Judiciário (atualizado por Gustavo Binenbojm), 2005, p. 180.
} 
agir. Subordinado sempre à legalidade de sua atuação, é lícito ao administrador se orientar livremente com referência à oportunidade e à conveniência dos atos administrativos. Esta capacidade de autodeterminação representa o poder discricionário do Estado, que se exaure plenamente no setor administrativo, não podendo ser objeto de consideração jurisdicional. A oportunidade do ato poderá, em certos casos, ser reexaminada pela própria Administração; em nenhuma hipótese poderá ser apreciada pelo Poder Judiciário, que, nessa matéria, está impedido de se manifestar. ${ }^{109}$

O entendimento que prevalecia era no sentido de que o judiciário não poderia imiscuirse nessa seara restrita à Administração, sob pena de substituir-se a discricionariedade do administrador pela do juiz.

Nesse contexto, a atuação discricionária da Administração afirmava-se como um espaço decisório totalmente infenso ao controle da jurisdição. ${ }^{110}$

4.5. Teoria do desvio de poder (dètournement de pouvoir)/desvio de finalidade.

A construção da teoria do desvio de poder e o desenvolvimento dessa forma de controle deveram-se, sobretudo, à ação do Conselho de Estado Francês ${ }^{111}$ que, depois de ter admitido ao lado da incompetência, o vício de forma, passou a anular os atos administrativos com fundamento em novo vício - 'Le détournement de pouvoir' -, espécie de excesso de poder $^{112}$, e que se traduzia no exercício dos poderes administrativos para fim diverso do previsto em lei.

\footnotetext{
${ }^{109}$ Poder Vinculado e Poder Discricionário, p. 316.

${ }^{110}$ Gustavo Binenbojm. Uma teoria do Direito Administrativo, p. 199.

${ }^{111}$ Celso Antônio Bandeira de Mello. Curso de Direito Administrativo, 27ª ed., p.979.

${ }^{112}$ Acerca do recurso por excesso de poder escreve Marcel Waline, "Le recours pour excès de pouvoir est une action en justice, par laquelle toute pérsonne intéressée peut demander aux tribunaux administratifs (en principe, au Conseil D'Etat) d'annuler toute décision illegale d'un administrateur" . ${ }^{112}$ Traité Elementaire de Droit Administratif, p. 105.

Como observou Duguit, "le recours pour excès de pouvoir est ouvert à toute personne ayant um intérêt, même simplement moral et indirect, à faire cesser les effets de l'acte ataque. En réalité jamais le recours pour excès de pouvoir n'a pour but et pour effet de santionner um droit subjectif de l'administré". Les transformations du Droit Public, p. 186.
} 
$\mathrm{Na}$ Itália, o vício do desvio de finalidade ficou conhecido como "sviamento di potere" e era uma das espécies de vícios dos atos administrativos que compunham o "gênero" eccesso di potere. ${ }^{113}$

Para Jaime Sánchez, aparece "la desviación de poder cuando la Administración actúa totalmente fuera de las competências - com finalidade espúrea en cuanto al acto administrativo de que se trata". 114

Para Augustín Gordillo “existe desviación de poder toda vez que el funcionário actúa com una finalidade distinta de la perseguida por la ley. El acto está así viciado aunque su objeto no sea contrario al orden jurídico". ${ }^{115}$

André de Laubadère, citado por Celso Antônio, sustentou que "há desvio de poder quando uma autoridade administrativa cumpre um ato de sua competência, mas em vista de fim diverso daquele para o qual o ato poderia legalmente ser cumprido". ${ }^{116}$

Quanto à natureza do desvio de poder, como sublinha Dinorá Adelaide Musetti Grotti, há alguma divergência. Para uns, é vício de legalidade, para outros, tem a ver com a própria moralidade administrativa. "Para Maurice Hauriou a tese do desvio de poder submetia a Administração a um controle de moralidade"117. Afonso Rodrigues Queiró, por sua vez, entende que este vício cinde-se em dupla natureza jurídica, sendo uma objetiva e outra subjetiva. A objetiva situa-se no domínio da ilegalidade e tem a ver com a incompetência, bastaria demonstrar que o ato não buscou o interesse público que a norma previa; já, a subjetiva, relaciona-se à imoralidade e refere-se à discricionariedade, à intenção do agente, ao seu comportamento doloso.

Para Eduardo Gárcia de Enterría e Tomás-Ramón Fernandez, o desvio de poder é vício de estrita legalidade “o que se controla através desta técnica é o cumprimento do fim

\footnotetext{
113 "O excesso de poder italiano não se limita à figura do desvio de finalidade, mas alcança uma grande quantidade de vícios dos atos administrativos, em especial os que decorrem do exercício de competência discricionária, dos quais podem ser destacados os seguintes: inexistência dos pressupostos de fato invocados, erro de fato, ilogicidade manifesta, injustiça manifesta, entre outros." Dinorá Adelaide Musetti Grotti. O Desvio de Poder em Atos Administrativos, p. 797. In: Floriano de Azevedo Marque Neto et al. Direito e Administração Pública.

${ }^{114}$ La desviacion de poder em la reciente jurisprudência, p. 22.

115 Tratado de Derecho Administrativo, p. IX-23

116 Traité Elémentaire de Droit Administratif, LGDF, $5^{\text {a }}$ ed., vol. I, 1970, pág. 502, n. 894, apud Celso Antônio Bandeira de Mello, Discricionariedade e Controle Jurisdicional, p. 56.

${ }^{117}$ Dinorá Adelaide Musetti Grotti. O Desvio de Poder em Atos Administrativos, p.803. In: Floriano de Azevedo Marques neto et al (organizadores). Direito e Administração Pública.
} 
concreto que a norma habilitante especifica e esse controle se realiza através de controles jurídicos estritos e não através de regras morais". 118

Maria Teresa de Melo Ribeiro ${ }^{119}$ entende também que o desvio de poder é vício de legalidade, já que é motivado por interesses particulares. Em sua tese, assentou que, a partir de meados do século XIX, invocando expressamente a teoria do desvio de poder, ou prenunciando a sua aparição, começam a ser frequentes as decisões de anulação de atos administrativos, tomadas pelo Conselho de Estado Francês, em que se pretendia um fim distinto daquele para o qual a lei concedeu poder à Administração; dando destaque aos julgados que foram os precursores do surgimento dessa teoria:

- No acórdão 'Duchesne', de 14 de junho de 1852 (e no mesmo sentido, no acórdão - Syndicat des arrosages de Sainte-Cécile -, de 4 de maio de 1854) o Conselho de Estado anulou uma decisão de um prefeito com fundamento em que a mesma havia sido fundada em interesses privados e individuais, alheios ao interesse geral;

No acórdão - Vernes -, de 19 de maio de 1858, foi anulada a decisão do alcaide que proibia os banhistas de se vestirem e despirem fora dos estabelecimentos municipais de banhos, pois chegou-se à conclusão que tal decisão não fora motivada por interesses relacionados com a administração, vigilância e polícia dos banhos de mar, mas por estritos interesses financeiros".

Nos acórdãos "Lesbasts", de 15 de fevereiro de 1864 e 17 de junho de 1865, o Conselho de Estado veio declarar que cometia excesso de poder a autoridade municipal que utilizava os seus poderes de controlar a circulação e o estacionamento nas praças perto da estação ferroviária, com o propósito de assegurar o monopólio da única empresa que tinha um contrato com a Companhia ferroviária;

No acórdão "Pariset", de 26 de novembro de 1875, foi anulada a decisão da Administração municipal que tinha ordenado o encerramento de uma unidade fabril invocando motivos relativos à sua natureza perigosa, incómoda e insalubre, pois o Conselho de Estado considerou que a decisão, embora tomada para fins de natureza pública (a redução da indenização a pagar pela expropriação decretada em consequência da criação de um monopólio legal do fabrico de tais produtos) não coincidia com o fim previsto na lei para a concessão de poderes de polícia nesta matéria.

A importância dessa teoria está no fato de que ela serviu para mostrar que o controle baseado somente em aspectos meramente formais dos atos discricionários não se mostrava suficiente para conter os abusos cometidos pela Administração. "Ao se admitir o controle do

\footnotetext{
${ }^{118}$ Ibidem, p.803.

${ }^{119}$ O Princípio da Imparcialidade da Administração Pública, p. 40/41.
} 
fim foi dado um passo relevante na fixação de parâmetros ao exercício do poder discricionário". 120

No Brasil ${ }^{121}$, o já mencionado acórdão do Tribunal de Justiça do Rio Grande do Norte da relatoria de Seabra Fagundes, no julgamento da Apelação Cível nº 1422 é considerado o primeiro acórdão que acolheu a teoria do desvio de finalidade. Por esse acórdão Seabra Fagundes não permitiu que a Administração Pública protegesse uma empresa de transporte, em detrimento da concorrente e dos usuários do serviço.

A alegação de desvio de poder ou desvio de finalidade encontra sério obstáculo no que diz respeito à prova da real intenção da autoridade. Torna-se muito difícil provar que a autoridade agiu por interesses pessoais, subjetivos.

Celso Antônio ${ }^{122}$ assinala em seu "Discricionariedade e Controle Jurisdicional”, "que não é fácil surpreender o vício do desvio de poder, de molde a capturá-lo nas malhas do Judiciário(..)". Com efeito, é preciso, de um lado, identificar a má intenção e, de outro, fazer-lhe a prova.

Nesse mesmo sentido é a posição de Oswaldo Aranha, em seu livro "Princípios Gerais de Direito Administrativo", edição de 1979, para quem:

a teoria do desvio de poder se acha em declínio, na França, como salientam os seus mais modernos administrativistas, pois o Conselho de Estado prefere, sempre que possivel, aplicar a teoria dos motivos determinantes, dada a dificuldade maior em apreciar-se a intenção do agente público que verificar-se o fato que constitui fundamento do ato, e se suficiente para justificá-lo. Então, o exame é objetivo, tendo em vista a importância e os

\footnotetext{
${ }^{120}$ Odete Medauar. Controle da Administração Pública, p. 217.

${ }^{121}$ No Brasil, em 1950, Caio Tácito apresentou a tese de livre-docência na Faculdade de Direito do Rio de Janeiro 'Desvio de Poder em matéria administrativa'e, em 1964, José Cretella Júnior obteve a livre docência de Direito Administrativo na Faculdade de Direito da Universidade de São Paulo com a tese 'Do desvio de poder'.

A despeito de já haver legislação fazendo expressa referência ao 'excesso de poder' na Lei n'. 221, de 20/11/1894 prevendo-o como vício passível de fundar a pretensão de anulabilidade do ato, e ao desvio de poder na Lei $\mathrm{n}^{\circ}$. 1.522, de 26/12/1951, a teoria do desvio de poder adquiriu renovada consagração na jurisprudência e na doutrina nacionais e alcançou definitiva afirmação na Lei da ação popular (Lei $\mathrm{n}^{\circ} .4 .717$, de 29/6/1965), cujo art. $2^{\circ}$. Inscreve a nulidade dos atos administrativos lesivos ao patrimônio da Administração Pública quando, dentre outros vícios, se marcarem de 'desvio de finalidade'; e issoocorre 'quando o agente pratica o ato visando a fim diverso daquele previsto, explícita ou implicitamente na regra de competência' (alínea 'e' do citado art. $2^{\circ}$.). Dinorá Adelaide Musetti Grotti. O Desvio de Poder em Atos Administrativos, p.800. In: Floriano de Azevedo Marques neto et al (organizadores). Direito e Administração Pública.

${ }^{122}$ Discricionariedade e Controle Jurisdicional, p. 77/78.
} 
elementos que provocaram o ato, na indagação da proporcionalidade deste com referência àqueles ${ }^{, 123}$.

Muito embora o controle finalístico tenha permitido uma ampliação do exame jurisdicional dos atos administrativos, a barreira ao exame do chamado mérito permanecia.

\subsection{Teoria dos motivos determinantes}

Ao largo desse controle finalístico, fundado na teoria do desvio de poder, desenvolveu-se a teoria dos motivos determinantes. Para Gustavo Binenbojm, de acordo com essa teoria, "a Administração deve responder pelos motivos que elege como pressuposto para a prática do ato administrativo. Diz-se haver uma vinculação administrativa tanto à realidade como à juridicidade das razões de fato apresentadas pelo administrador na motivação do ato". ${ }^{124}$

Motivo é o acontecimento objetivo que leva à edição do ato e que, logicamente, ocorre antes de sua edição.

Para Maria Sylvia Zanela Di Pietro,

Define-se motivo como o pressuposto de direito e de fato que serve de fundamento ao ato administrativo. Pressuposto de direito é o fato descrito na norma (hipótese da norma) como fundamento de determinado ato. Pressuposto de fato, como o próprio nome indica, corresponde ao conjunto de circunstâncias, de acontecimentos, de situações que levam a Administração a praticar o ato.

Para Celso Antônio ${ }^{125}$, "motivo é a situação de direito ou e fato que autoriza ou exige a prática do ato".

E enfatiza que, "se a regra de direito enuncia que um dado ato pode (ou deve) ser produzido quando presente determinado motivo (isto é, uma dada situação de fato), resulta óbvio ser condição da lisura da providência adotada que efetivamente tenha ocorrido ou seja existente aquela situação pressuposta na norma a ser aplicada. Se o fato presumido pela lei

\footnotetext{
${ }^{123}$ Princípios Gerais de Direito Administrativo, p. 486.

${ }^{124}$ Uma Teoria do Direito Administrativo, p. 206.

${ }^{125}$ Discricionariedade e controle jurisdicional, p. 86.
} 
não existe, sequer irrompe a competência para expedir o ato, pois as competências não são conferidas para serem exercidas a esmo" $" 126$.

Edmir Netto de Araújo ${ }^{127}$ utiliza-se de fórmula simples para conceituar "motivo",

Diante da ocorrência de certo evento material ou fato jurídico, ou da constatação de determinada situação jurídica, o sujeito (Estado, por seus governantes, legisladores, dirigentes, agentes administrativos que podem ser a mesma pessoa que vai praticar o ato, ou outras) compara essa circunstância com um interesse público concretamente existente (prestação regular e contínua de serviço público, p. ex.)e conclui que se impõe a tomada de certa providência (ato administrativo) para a realização prática e operante daquele interesse público concreto.

Esse impulso da vontade decorrente do binômio evento-situação mais interesse público concreto é nada mais que o motivo, e a realização efetiva do interesse (prestação efetiva daquele serviço público) é nada menos que a finalidade.

Em resumo, por essa teoria, a Administração é responsável pelo motivo que elenca ao praticar o ato administrativo e o controle abarca o exame dos motivos que forem elencados como suficientes para a prática do ato.

Segundo Oswaldo Aranha, a teoria dos motivos determinantes considera:

as circunstâncias de fato que legitimam o ato administrativo que o agente, no exercício do seu poder discricionário, deve verificar ao praticá-lo. Assim, não pode fundamentar o ato em motivo inexistente ou impróprio nos termos qualificados pela lei. Suponha-se a proibição de construir em dado local, fundada em lei que permite essa medida, mas para resguardar perspectivas monumentais, quando tal perspectiva, na verdade é mesquinha. Desnatura, então, o ato jurídico, exerce a discrição de forma anormal, além do poder que lhe cabe, em função do ato jurídico e do fato que o suscita, e, portanto, fora do seu motivo legal determinante. ${ }^{128}$

Onofre Mendes Junior, citado por Edimur Ferreira de Faria, escreveu:

A existência de motivo é indispensável à prática do ato administrativo, pois o motivo é o fundamento, a própria razão de ser do ato. Objetivamente, a existência do motivo está na lei. Esta é que dá fundamento ao ato. O motivo deve ser determinado por meio de 'juizo lógico e racional', que o ponha em relação às circunstâncias de fato, em cada caso concreto. ${ }^{129}$

Quando se fala em motivo surge a ideia de motivação, que é a explicitação dos pressupostos fáticos que levaram a Administração a editar o ato administrativo.

\footnotetext{
${ }^{126}$ Discricionariedade e Controle Jurisdicional, p. 86.

${ }^{127}$ Curso de Direito Adminiostrativo, p. 512.

${ }^{128}$ Princípios Gerais de Direito Administrativo, vol. I, p. 486.

${ }^{129}$ Mendes Junior, Onofre. Direito Administrativo, 2, d. Belo Horizonte: Bernardo Alvares, 1961. 1 v., p. 224, apud Controle do Mérito do Ato Administrativo pelo Judiciário, p. 172.
} 
Importante que na motivação, ou seja, na explicitação dos motivos, sejam inseridos todos os elementos indispensáveis para o controle da legalidade, bem como dos limites da discricionariedade. A exigência de motivação, hoje considerada imprescindível em qualquer tipo de ato, foi provavelmente uma das maiores conquistas em termos de garantia de legalidade dos atos administrativos. assinala Di Pietro ${ }^{130}$.

Sobre a necessidade de motivação ${ }^{131}$, Cassagne $^{132}$ destaca:

como es sabido, la motivación -en cuanto expresión de las razones y fines que llevan a la Administración a emitir el acto administrativo - (que además debe consignar los antecedentes de hecho y de derecho) constituye um requisito de forma esencial para la validez del acto administrativo en la medida que traduce su justificación racional al plano exterior.

4.7. Teoria da vinculação dos atos aos princípios

El aumento de la intervención de la Administración em todos los âmbitos de la vida hacen que, como há dicho García de Enterría, 'la única posibilidad de uma garantia individual y social efectiva frente a los formidables poderes de esta naturaleza' (el autor apunta a la figura del caballo de Troya dentro del Derecho administrativo de um Estado de Derecho, según la conocida frase de Huber), “...de la Administracion de hoy está em la técnica de los principios generales del Derecho. ${ }^{133}$

A noção vigente na atualidade, do caráter normativos dos princípios, levou à mudança na concepção de legalidade, que cedeu lugar à noção de juridicidade. Segundo Emerson Garcia, citando Enterría y Ramon Fernández, a cunhagem desse termo deve-se a Merkl, que incluiu sob o signo do princípio da juridicidade todo o ordenamento jurídico, abrangendo os regulamentos, os princípios gerais, os costumes etc., tendo reservado a nomenclatura de princípio da legalidade unicamente à lei em sentido formal. ${ }^{134}$ Assim, a atuação do Estado

\footnotetext{
${ }^{130}$ Discricionariedade na Constituição de 1988, p. 136.

${ }^{131}$ Cassagne (p. 204/205) destaca também que "en las decisiones o elementos discrecionales de los actos que dicta la Administración la obligatoriedad de la motivación obedece a dos razones fundamentales. La primera, como señala Fernández, permite deslindar la discrecionalidad de la arbitrariedade, ya que el no haber motivación e lacto administrativo aparece, em el mundo jurídico, 'como um produto de la sola y exclusiva voluntad del órgano que lo dicta, lo que resulta incompatible com el Estado de Derecho', que es gobierno del derecho y no de los hombres. La segunda razón tiene que ver com la tutela judicial efectiva y, más precisamente, com la garantia de la defensa (art. $18 \mathrm{CN}$ ), pues si el acto no se encuentra motivado, el particular se hala impedido de ejercer las facultades que integram el llamado debido processo adjetivo (derecho a ser oído, a oferecer y producir pruebas y a uma decisión fundada)".

${ }_{132}^{132}$ El Principio de legalidade y el control judicial de la discrecionalidad administrativa, p. 204.

133 Juan Carlos Cassagne. El Principio de Legalidad y el Control Judicial de la Discrecionalidad Administrativa, p. 25.

${ }_{134}$ O Direito Comunitário e o Controle do Poder Discricionário pela Justiça Administrativa, in Discricionariedade Administrativa, $p$.
} 
deve estar em perfeita harmonia com o Direito, o que afasta a idéia de legalidade estrita, passando a compreender não mais só a lei formal, mas também os princípios.

No Brasil, a partir de 1988, ocorreu a constitucionalização dos princípios da Administração Pública, dispondo o artigo 37 acerca dos princípios de observância obrigatória para a Administração Pública. A par desses princípios específicos, outros mais gerais têm também sido utilizados, como os princípios gerais de direito, como técnica de controle jurisdicional da atuação administrativa.

Juarez de Freitas sustenta que:

Na missão de bem controlar os atos administrativos, avulta em importância, em lugar de controles meramente formalistas, cotejá-los com a totalidade do sistema constitucional do Direito Administrativo em sua dimensão de rede hierarquizada de princípios, normas e valores, não vigiando apenas a observância quanto à legalidade estrita de outrora. Assim, a própria noção de controle, excessivamente limitada a juízos de mera conformação às regras, haverá de experimentar dignificação e realce em termos de efetividade, máxime na tarefa de outorgar concretização aos princípios superiores estatuídos na constituição. Em outras palavras, o critério decisivo para estimar uma adequada atuação controladora reside, justamente, no zelo pela íntegra dos princípios regentes da Administração Pública, sobretudo quando se mostrar justificável a preponderância episódica de um, sem exclusão ou supressão recíproca dos demais". ${ }^{135}$

Para Gustavo Binenbojm, cada vez mais, os princípios se tornam instrumentos de conformação do conteúdo da decisão discricionária, o que, inevitavelmente, proporciona ao juiz uma ingerência crescente sobre aquilo que se convencionou chamar de mérito da decisão. ${ }^{136}$

Os princípios da publicidade, impessoalidade, moralidade, eficiência, razoabilidade e proporcionalidade, como observa Germana de Oliveira Moraes, viabilizaram e forneceram os critérios materiais que possibilitaram a extensão do controle jurisdicional para além da legalidade. $^{137}$

4.8. Conceitos Jurídicos indeterminados

\footnotetext{
${ }^{135}$ O Controle dos Atos Administrativos e os Princípios Fundamentais, p. 19.

${ }^{136}$ Uma Teoria do Direito Administrativo, p. 209.

${ }^{137}$ Controle Jurisdicional da Administração Pública, p. 106/107.
} 
Não é possível falar-se em Direito sem referência à linguagem. A relação entre direito e linguagem traduz-se numa vinculação essencial. Não existe direito sem linguagem. Sainz Moreno, citado por Regina Helena Costa ${ }^{138}$, avalia que o caráter da linguagem jurídica consiste em que o significado dos termos que utiliza, procedentes, em sua parte, da linguagem ordinária, sofre, por sua incorporação a um vocábulo jurídico, uma certa mutação em seu significado originário.

Ao se falar em conceitos jurídicos há que se ter em mente que esses conceitos jurídicos se diferenciam dos demais conceitos em razão do seu objeto. O objeto do conceito jurídico não tem uma existência concreta, palpável. O “objeto" do conceito jurídico não existe "em si”; dele não há representação concreta, nem mesmo gráfica. O objeto do conceito jurídico é uma significação atribuível a uma coisa, estado ou situação e não a coisa, estado ou situação em si. O conceito jurídico não se vincula a determinada realidade material, mas sim a significado do que deve ser. ${ }^{139}$

Regina Helena Costa define os conceitos indeterminados no âmbito do direito como "aqueles cuja realidade a que se referem não aparece bem definida, cujo conteúdo e extensão não estão delimitados precisamente". ${ }^{140}$

O Direito, ao prescrever conduta, necessita que o conteúdo desta seja transferido aos seus destinatários e, para isso, as palavras são utilizadas como veículo para informar e transferir esse conteúdo. “As características de imprecisão e de contextualidade do significado das palavras, presentes na linguagem comum, projetam-se na linguagem jurídica e geram dificuldades no processo de interpretação e de aplicação das normas." ${ }^{\text {141 }}$.

Marçal Justen sublinha, entretanto, que:

A ausência de determinação precisa não é um defeito do conceito, mas um atributo destinado a permitir sua aplicação mais adequada caso a caso. A indeterminação dos limites do conceito propicia a aproximação do sistema normativo à riqueza do mundo real". ${ }^{142}$ Regina Helena Costa afirma também que "nem sempre se deve considerar a indeterminação dos conceitos como uma imperfeição ou vício da linguagem cotidiana, senão como uma de suas propriedades que permite cumprir a função de expressar e valorar condutas, relações e objetos materiais ${ }^{, 143}$.

\footnotetext{
${ }^{138}$ Conceitos Jurídicos indeterminados e discricionariedade administrativa, p. 35.

${ }^{139}$ Conceitos jurídicos indeterminados e discricionariedade administrativa, p. 36

140140 Conceitos jurídicos indeterminados e discricionariedade administrativa, p. 46.

${ }^{141}$ Germana de Oliveira Moraes. Controle Jurisdicional da Administração Pública, p. 56.

142 Curso de Direito Administrativo, p. 208.

${ }^{143}$ Conceitos Jurídicos indeterminados e discricionariedade administrativa, p.
} 
O estudo dos conceitos jurídicos indeterminados teve início na Áustria com Edmund Bernatizek e Friedrich Tezner, no século XIX, que desenvolveram teorias antagônicas acerca da aplicação dos conceitos jurídicos indeterminados.

Bernatizek, em obra de 1886, sustentou que os conceitos legais indeterminados conferiam à Administração Pública competência discricionária, ensejando a possibilidade de várias opções válidas, ante o caso concreto. Tezner, por sua vez, em obra de 1888, discordou desse posicionamento argumentando que a ideia de discricionariedade dos conceitos legais indeterminados incompatibiliza-se com o Estado de Direito. Para Tezner o que diferencia um conceito legal indeterminado e outro determinado é apenas o grau de segurança da palavra. ${ }^{144}$

As teorias da multivalência e da univocidade originaram-se desses posicionamentos doutrinários de Bernatizek e Tezner. Pela teoria da multivalência a interpretação e a aplicação dos conceitos legais indeterminados levam a várias opções válidas, campo da discricionariedade. Pela teoria da univocidade há apenas uma solução válida em conformidade com a lei, os conceitos jurídicos indeterminados enquadrar-se-iam no campo da vinculação $^{145}$.

Na Alemanha, a princípio, predominou a teoria da univocidade e, após a Segunda Guerra Mundial, essa doutrina se impôs à jurisprudência alemã. Aceito, de início, pacificamente pela doutrina e jurisprudência, passou a ser questionada. Forsthoff, citado por Germana Moraes, defende, na Alemanha, a aplicação da teoria da multivalência; teoria esta que tivera ressonância em países como França e Portugal. Forsthoff faz distinção entre conceitos empíricos, que para ele não seriam discricionários, dos conceitos de valor, que para ele seriam discricionários. ${ }^{146}$

Surge, na década de 50, com Otto Bachof, a teoria da "Margem de Livre Apreciação", segundo a qual, reconhece-se "em favor da Administração, no processo de aplicação de determinada categoria de conceitos indeterminados, certa liberdade uma margem de apreciação, um espaço de apreciação ou uma prerrogativa de estimativa, ou seja, uma área de atuação administrativa de impossibilidade de sindicância judicial”.

\footnotetext{
${ }^{144}$ Controle do Mérito do Ato Administrativo pelo Judiciário, p. 186.

145 Germana de Oliveira Moraes, p. 66.

${ }^{146}$ Ibidem, p. 66.
} 
Entre os opositores a essa teoria cita-se Garcia de Enterría, para quem é sempre possível o controle jurisdicional da aplicação dos conceitos jurídicos indeterminados. $\mathrm{Na}$ doutrina portuguesa, Antônio Francisco de Sousa não aceita a teoria da margem de apreciação, pois a considera inconstitucional e contrária ao princípio do Estado de Direito. ${ }^{147}$

Di Pietro ${ }^{148}$, citando António Francisco de Sousa, sublinha que o autor diferencia conceito jurídico indeterminado de discricionariedade. Para ele, discricionariedade revela a liberdade de escolha entre alternativas igualmente justas, já que a decisão se baseia em critérios extrajurídicos (de oportunidade, econômicos etc.), não inclusos na lei e subordinados ao juízo exclusivo da Administração. Já, a aplicação do conceito jurídico indeterminado é um caso de aplicação da lei, em que se faz a subsunção de uma determinada situação real a uma categoria legal, sendo por isso, um processo vinculado que se esgota no processo intelectivo de compreensão de uma realidade, não se verificando decisão de vontade do aplicador, como no exercício discricionário.

Para Regina Helena Costa ${ }^{149}$, na esteira de Forsthoff, classifica os conceitos jurídicos indeterminados em duas espécies: conceitos de experiência e conceitos de valor; sendo os de experiência de natureza objetiva e consubstanciada na vivência e interpretação e os de valor ligados à inexistência de elementos objetivos e claros e ao predomínio do subjetivo;

\begin{abstract}
"quando se trata de conceitos de experiências, o administrador, após socorrer-se do processo interpretativo, torna preciso o conceito, não lhe restando qualquer margem de liberdade de escolha de seu significado. Quando estivermos diante de conceitos de valor, diversamente, caberá àquele, terminada a interpretação, uma vez restando ainda um campo nebuloso do conceito que esta não foi suficiente para eliminar, definir o conceito por intermédio de sua apreciação subjetiva, que outra não é que a própria discricionariedade”.
\end{abstract}

Em síntese, em relação aos conceitos jurídicos indeterminados, há duas posições fundamentais: a) posição dos que entendem que os conceitos indeterminados não conferem discricionariedade, vez que a Administração faz um trabalho de interpretação para chegar à única solução válida possível; b) posição daqueles que entendem que os conceitos indeterminados podem conferir discricionariedade à Administração, desde que se trate de conceitos de valor, que impliquem a possibilidade de apreciação do interesse público, no caso concreto.

\footnotetext{
${ }^{147}$ Ibidem, p. 70.

${ }^{148}$ Discricionariedade Administrativa na Constituição de 1988, p. 105.

${ }^{149}$ Conceitos jurídicos indeterminados e discricionariedade administrativa, p. 98.
} 
Como conclui Edimur Ferreira de Faria ${ }^{150}$, o elemento valorativo não concorre no estabelecimento do núcleo do conceito indeterminado, a não ser em casos excepcionalíssimos. A discricionariedade admitir-se-ia, somente em casos extremos, ou seja, naqueles cujo procedimento interpretativo tenha se esgotado, e ainda tenha restado alguma obscuridade que deixe margem a um processo de escolha. A regra é a intelecção e não a escolha.

\subsection{Discricionariedade técnica}

O termo 'discricionariedade técnica' surgiu com Bernatzik, um dos autores da escola de Viena, que entendia que as decisões que compreendiam análises de alta complexidade técnica deviam ser retiradas do controle jurisdicional. Somente o administrador público, em contato com a realidade, teria condições de apreciar adequadamente.

Sublinha Di Pietro ${ }^{151}$ que, no direito italiano, "os conceitos indeterminados são objeto de análise a partir da distinção entre discricionariedade administrativa, que seria a verdadeira discricionariedade, e discricionariedade técnica, que é uma discricionariedade imprópria".

Edmur de Faria ${ }^{152}$ assinala que "a discricionariedade técnica consiste na liberdade que tem o administrador público para escolher os meios e a técnica mais adequada para a execução de determinado serviço ou construção de certa obra".

Sobre o tema, ensina Rafael Bielsa ${ }^{153}$ que,

em general, la actividad técnica puramente es considerada como actividad libre de la Administración. Y se compreende que cuando tal actividad no se la rifiere a derecho o a interesses legítimos de los administrados, no puede hablarse ni de actividad reglad ni de actividad discrecional. ...... en punto a las normas técnicas no hay libertad de apreciación legal o administrativa, sino procedimentos (uno o más) cientificamente determinados".

Afirma o autor, entretanto, que "si la Administración pública dicta uma decisión fundada em apreciaciones técnicas erróneas; por ejemplo, si ordena la demolición de um edifício em razón de que su falta de solidez constituye um peligro, tal decisión es ilegítima,

\footnotetext{
${ }^{150}$ Controle do Ato Administrativo pelo Poder Judiciário, pág. 196.

${ }^{151}$ Discricionariedade administrativa na Constituição de 1988, p. 106.

152 Controle do mérito do ato administrativo pelo judiciário, p. 151.

${ }^{153}$ Princípios de Derecho Administrativo, p. 193/194.
} 
porque el presupuesto de toda actividad administrativa es la legitimidade"154. Desta forma, se as normas técnicas que deram suporte ao ato contiverem falsidade ou erro, o controle poderá incidir sobre o ato.

Para Régis de Oliveira ${ }^{155}$, "não se pode falar em discricionariedade técnica. Se algum ato necessita de regras técnicas para ser editado, são elas anteriores a sua emanação. Demais, pela técnica apenas se pode chegar a uma única conclusão".

Afirma o mesmo autor que o "elemento técnico, em alguns casos, é pressuposto ou antecedente, fornecendo elementos para o exercício do poder discricionário”. E, caso a própria lei exija o parecer técnico para a realização de determinada atividade, em tal circunstância estar-se-á diante de ato vinculado.

Marçal Justen ${ }^{156}$ assinala que:

alude-se à discricionariedade técnica para indicar que determinadas decisões administrativas se fundam em critérios técnico-científicos, os quais não são incorporados no corpo normativo produzido legislativamente". Segundo o mesmo autor, que cita Gianini, a expressão discricionariedade técnica não apresenta nada de discricionariedade e é assim denominada por um erro histórico da doutrina. Na sequência, Marçal Justen afirma que "nos casos de discricionariedade técnica, a lei não autoriza uma escolha de natureza política, a ser realizada pelo aplicador. O silêncio legislativo sobre a solução cabível resulta de outras razões. A norma legal estabelece parâmetros normativos gerais. A Administração disporá de autonomia para decidir, mas a escolha concreta deverá vincular-se a juízos técnicocientíficos. Será a ciência ou a técnica que fornecerá a solução a ser adotada".

Na Itália, citado por Di Pietro ${ }^{157}$, Renato Alessi, foi um dos autores que se dedicou ao tema, afirmando que há casos em que a apreciação do interesse público exige somente a utilização de critérios administrativos, como é o caso, por exemplo, da concessão de licença para o porte de armas, hipótese em que se está diante de uma discricionariedade administrativa. Há casos, entretanto, em que a referida apreciação necessita da utilização de critérios técnicos, como é o caso de se ordenar a matança de animais atacados por enfermidades infecciosas. Para Alessi, a solução é diferente conforme os conceitos técnicos estejam ou não ligados a critérios administrativos. Há casos em que a discricionariedade técnica permite uma apreciação da Administração em face do interesse público. Em outros,

\footnotetext{
${ }^{154}$ Ibidem, p. 194.

155 Ato administrativo, p. 76.

${ }^{156}$ Curso de Direito Administrativo, p. 217.

${ }^{157}$ Discricionariedade administrativa na Constituição de 1988, p. 107.
} 
diante da manifestação do órgão técnico, a Administração não pode valorar em que medida o fato afeta o interesse público, a ela cabe decidir em consonância com as condições técnicas previamente definidas pela lei ${ }^{158}$.

No Direito norte-americano, a discricionariedade técnica está relacionada à delimitação da competência das agências reguladoras, no sentido de definir os limites de sua função normativa, bem como para estabelecer os limites do controle judicial.

$$
\text { Como sublinha Di Pietro }{ }^{159} \text {, }
$$

sendo adotado o princípio da separação de poderes, houve a necessidade de criar uma doutrina que desse fundamento à delegação de função legislativa às agências reguladoras. Afirma, ainda, que se desenvolveu nos Estados Unidos a técnica dos standards, pela qual a lei se limita a estabelecer parâmetros, diretrizes, princípios, conceitos indeterminados, ficando para as agências a função de baixar normas regulamentadoras, que devem se conformar aos standards contidos na lei e na Constituição.

Destaca, ainda, Di Pietro ${ }^{160}$ que os processo de elaboração das normas pelas agências têm que estar munidos de documentação com dados suficientes, de modo a permitir o exame da racionalidade da regulação diante dos fatos (correlação entre fatos -motivos - e a decisão), pelo judiciário. Assim, o anterior procedimento informal de elaboração dos regulamentos, tendo por base a ideia de especialização das agências, transformou-se em procedimento altamente formal, já que suas "normas têm que ser amplamente motivadas, com o objetivo de demonstrar a correlação entre fatos e normas e a razoabilidade das normas diante dos parâmetros contidos na lei".

A doutrina espanhola, com fundamento na doutrina italiana identificou duas subespécies da 'discricionariedade técnica', com o objetivo de fazer distinção entre a atividade meramente interpretativa do administrador, que é a discricionariedade instrumental jurídico técnica; e a discricionariedade técnico-administrativa.

No Brasil, o interesse pelo tema da discricionariedade técnica surgiu mais forte, a partir do momento em que começaram a ser criadas as agência reguladora, inspiradas no

\footnotetext{
${ }^{158}$ Como exemplo, "quando a lei determina a destruição de mercadorias deterioradas, à Administração cabe apenas constatar a ocorrência de deterioração e determinar sua destruição; não lhe cabe valorar a medida em face do interesse público".

${ }^{159}$ Discricionariedade administrativa na Constituição de 1988, p. 110.

160 Ibidem, p. 111/2.
} 
sistema de "common law". ${ }^{161}$ Afirma Di Pietro ${ }^{162}$ que esse instituto, relacionado ao da agência reguladora teve como modelo o direito norte-americano.

Finaliza Di Pietro ${ }^{163}$, ao afirmar que:

Se a lei utiliza conceitos técnicos, não há discricionariedade propriamente dita, Não há opções a serem feitas por critérios de oportunidade e conveniência. Não há decisão política a ser tomada conforme avaliação do interesse público. Existe uma solução única a ser adotada com base em critérios técnicos fornecidos pela ciência.

(...)quando um ente administrativo pratica atos normativos definindo conceitos indeterminados, especialmente os conceitos técnicos e os conceitos de experiência, ele não está exercendo poder regulamentar, porque este supõe a existência de discricionariedade administrativa propriamente dita, a qual, no caso, não existe. Se a lei fala, por exemplo, em produtos perigosos para a saúde, a agência pode baixar ato normativo definindo esses produtos ou mesmo elaborando uma lista deles; isto não se insere no poder regulamentar, porque se trata de conceito técnico cujo conteúdo é dado com base em conhecimentos científicos de que a agência dispõe ou deveria dispor. ${ }^{164}$

Para Luís Manuel Fonseca Pires ${ }^{165}$, “as apreciações técnicas, por não caracterizarem uma espécie de discricionariedade administrativa, estão sujeitas ao pleno controle judicial”.

\footnotetext{
${ }^{161}$ Ibidem, p. 120.

${ }^{162}$ Ibidem, p. 120.

${ }^{163}$ Ibidem, p. 122.

164 Ibidem, p. 123

${ }^{165}$ Controle Judicial da Discricionariedade Administrativa, p. 235.
} 


\section{Parte 2 - O Controle dos Atos Administrativos Discricionários pelos Tribunais}

A pesquisa realizada para a elaboração desta dissertação impõe admitir-se a existência de tendência em nossos Tribunais, no sentido de acolher a ideia de um controle jurisdicional amplo dos atos administrativos, o que incluiria a análise do chamado mérito administrativo.

Se bem que existem ainda julgados repetindo o mantra de que não cabe ao Poder Judiciário imiscuir-se no mérito do ato administrativo, ou seja, verificar os aspectos de conveniência e oportunidade.

O primeiro acórdão analisado foi o relativo à apelação cível $n^{\circ} .1422$, do Tribunal de Justiça do Rio Grande do Norte, cuja relatoria ficou a cargo do Desembargador Seabra Fagundes e cuja ementa tem o seguinte teor:

No que concerne à competência, à finalidade e à forma, o ato discricionário está tão sujeito aos textos legais como qualquer outro. $\mathbf{O}$ ato que, encobrindo fins de interesse público, deixa às mostras finalidades pessoais, poderá cair na apreciação do Poder Judiciário, não obstante originário do exercício de competência livre. $O$ "fim legal" dos atos da Administração pode vir expresso ou apenas subentendido na lei. $O$ direito que resulta, não da letra da lei, mas do seu espírito, exsurgindo implicitamente do texto, também pode apresentar a liquidez e certeza que se exigem para concessão do mandado de segurança.

Esse acórdão pode ser considerado o "leading case" de nossa jurisprudência e acolheu a tese do desvio de finalidade. Como lembra, Dinorá Adelaide Musetti Grotti ${ }^{166}$, o objeto da discussão travada neste acórdão guarda certa semelhança com o precedente Francês representado pelo caso "Lesbats", já mencionado nesta pesquisa.

Além da apelação cível $\mathrm{n}^{\circ}$. 1422 foram também analisados alguns julgados do Supremo Tribunal Federal, do Superior Tribunal de Justiça e do Tribunal de Justiça de São Paulo, como se verá a seguir.

\footnotetext{
${ }^{166}$ O Desvio de Poder em Atos Administrativos, p.800. In: Floriano de Azevedo Marques neto et al. Direito e Administração Pública
} 


\title{
5. Tribunal de Justiça do Rio Grande do Norte
}

\author{
5.1. Apelação cível nº 1.422 - Relator: Desembargador Miguel Seabra \\ Fagundes
}

\subsubsection{Considerações Iniciais}

Não seria conveniente discorrer sobre a jurisprudência que envolve o controle dos atos administrativos discricionários no Brasil, sem fazer referência ao acórdão do Tribunal de Justiça do Rio Grande do Norte na apelação ${ }^{\circ}$. 1.422.

O presente capítulo tem, então, por finalidade, analisar o acórdão proferido na apelação cível $\mathrm{n}^{\circ}$. 1.422, datado de 28 de julho de 1948, cuja relatoria ficou a cargo do Desembargador Miguel Seabra Fagundes.

Importante destacar que o interesse do acórdão está baseado muito menos em relação à questão de fato debatida e muito mais em relação à inovação manifestada por Seabra Fagundes ao admitir, em seu voto, a possibilidade do controle judicial sobre os atos discricionários, ao tratar da ocorrência de desvio de finalidade em ato praticado pela administração.

Victor Nunes Leal, em comentário ao acórdão, afirmou tratar-se "de preciosa contribuição às nossas letras jurídicas, num dos pontos mais delicados do direito administrativo" 167 , que é o tema do controle jurisdicional dos Atos da Administração. Afirmou também que o acórdão rompeu "a praxe reiterada dos nossos tribunais que sempre declararam os atos discricionários insuscetíveis de apreciação jurisdicional, sem aprofundar a questão da possível arbitrariedade do poder discricionário" ${ }^{\text {"168 }}$.

\footnotetext{
167 www.planalto.gov.br/ccivil_03/revista/Rev_35/panteao.htm

${ }^{168}$ www.planalto.gov.br/ccivil_03/revista/Rev_35/panteao.htm
} 


\subsubsection{Apelação Cível no 1.422}

A compreensão dos aspectos que envolvem a decisão passa, necessariamente, pelo conhecimento dos fatos conforme descritos no acórdão.

Originariamente tratava-se de mandado de segurança, requerido pela Empresa de Transporte Potiguar Ltda. contra a Inspetoria Estadual de Trânsito, para que lhe fosse assegurado o direito de fazer trafegar seus veículos sem qualquer restrição prejudicial aos seus interesses, entre a Capital e algumas cidades. Segundo consta, empecilhos de toda natureza foram opostos ao serviço de transporte de passageiros da impetrante; sem nenhuma razão de interesse público, a autoridade policial pretendia beneficiar uma empresa de transportes concorrente, inclusive com sacrifício para os passageiros.

“A Empresa de Transporte Potiguar requerera mandado de segurança contra a Inspetoria Estadual de Trânsito para que lhe fosse assegurado o direito de fazer trafegar os seus veículos sem qualquer restrição prejudicial aos seus interesses, não só entre esta Capital e as cidades de Macaíba e São José de Mipibú, como aliás, entre aquelas e, também desta mesma capital para todo o Estado.

Houve a citação da autoridade coatora, tenente-coronel Joaquim Teixeira de Moura e do dr. Segundo Procurador Fiscal do Estado.

A Procuradoria Fiscal contestou suscitando a preliminar de não cabimento de mandado de segurança por não ser líquido e certo o direito pleiteado e por não se tratar de ato reconhecidamente ilegal; e, quanto ao mérito pediu a improcedência, uma vez que a fixação de horários e viagens foi feita de acordo com a lei.

Denegado o mandado, o requerente apelou e arrazoou."

Inicialmente foi desprezada a preliminar suscitada na contestação de não cabimento do mandado de segurança. O relator apontou que o conteúdo do parágrafo 24 do art. 141 da Constituição federal ${ }^{169}$ se aplicaria, justamente, para decidir o mérito da medida requerida e não para amparar o suscitante.

\footnotetext{
${ }^{169}$ Art 141 - A Constituição assegura aos brasileiros e aos estrangeiros residentes no País a inviolabilidade dos direitos concernentes à vida, à liberdade, a segurança individual e à propriedade, nos termos seguintes:

24 - Para proteger direito líquido e certo não amparado por habeas corpus, conceder-se-á mandado de segurança, seja qual for a autoridade responsável pela ilegalidade ou abuso de poder.
} 
Considerou o relator também a aplicação do parágrafo $1^{\circ}$ do mesmo artigo ${ }^{170}$ 141, preceito que deu ensejo a que a Turma afetasse, por maioria, ao Tribunal pleno o julgamento do caso, em razão da ocorrência de desigualdade de tratamento entre as empresas de transporte, por parte da Inspetoria Estadual de Trânsito.

Quanto ao mérito, foi julgado procedente o pedido para conceder o mandado de segurança requerido pela Empresa de Transporte Potiguar Ltda contra a Inspetoria Estadual de Trânsito, nos termos do voto do des. Miguel Seabra Fagundes.

O exercício do poder de polícia da autoridade estadual competente, exteriorizado por meio de ato da Inspetoria Estadual de Trânsito, apesar de justificar-se como "legal", visava prejudicar uma das empresas em benefício da concorrente. Tal ocorrência pode ser verificada por meio de análise dos fatos e atos, assim, importante retratar as circunstâncias existentes e que levaram à impetração do mandado de segurança.

Conforme constou do relatório, até então, não houvera restrição alguma ao tráfego dos ônibus para as cidades vizinhas, nem mesmo fora estabelecido qualquer horário para circulação dos ônibus e esse critério vinha sendo mantido em relação ao tráfego de ônibus para outras cidades, até mesmo na capital.

A Inspetoria Estadual de Trânsito, com o intuito de favorecer outra empresa do ramo, estabeleceu novo horário para circulação de ônibus entre a cidade de São José de Mipibu e a capital do Estado. Quatro ônibus fariam a ligação entre São José de Mipibu e a Capital, a partir das 5 horas da manhã, com intervalo de meia hora entre os coletivos. Seria facultada a realização de viagens extras aos domingos (impetrante) e sábado (empresa concorrente).

A Empresa de Transporte Potiguar Ltda, impetrante, requereu permissão à Inspetoria para colocar outro ônibus partindo às 7 horas e regressando às 17 horas, vez que esse horário atenderia interesse dos passageiros que se deslocavam para trabalhar na Capital. A circulação de ônibus no horário solicitado pela impetrante não coincidia com outro ônibus dela própria, nem da concorrente.

Alguns dias depois a Inspetoria permitiu a circulação de mais um ônibus, mas, em horário diverso do solicitado e que não atendia aos interesses da população e da empresa.

\footnotetext{
${ }^{170} \S 1^{\circ}$ Todos são iguais perante a lei.
} 
"Jamais houve restrição ao tráfego dos veículos da impetrante, não tendo sido estabelecido qualquer horário; aliás, a impetrante (Inspetoria Estadual de Trânsito) vem mantendo aquele critério_relativamente ao tráfego de ônibus para outras cidades do Estado, inclusive Macaíba, e até mesma nesta Capital, onde prestam serviço cerca de trinta (30) ônibus, de diversos proprietários. Em relação à cidade São José de Mipibu, a aludida Inspetoria, para satisfazer solicitação de outro concorrente, estabeleceu um horário de ônibus devendo sair quatro da mesma cidade para esta Capital a partir da 5 horas do dia, com intervalo de meia hora um do outro, sendo facultado à impetrante efetuar viagens extras aos domingos e, ao seu concorrente, aos sábados; empecilhos de toda a natureza opostos ao seu serviço de transporte de passageiros, levaram a impetrante, mesmo para ficar ressalvada de tantos aborrecimentos, solicitar da repartição apelada novo horário de mais fácil fiscalização: e, assim, principalmente para satisfazer os desejos da população daquela cidade, em que residem várias pessoas funcionárias nesta capital, propôs à referida apelada estabelecer mais um ônibus, partindo de lá, às sete horas do dia e regressando às 17 horas; entretanto, a Inspetoria, alguns dias depois, permitiu a circulação de mais um ônibus, mas em horário que não servia para os empregados nesta capital; finalmente, como em relação ao horário, o mesmo não coincidiria com qualquer outro de seus ônibus, ou da empresa "serviço de Transporte Mipibuense". ${ }^{171}$

O voto do desembargador Seabra Fagundes tem início com o enquadramento do ato da Inspetoria Estadual de Trânsito como ato de competência discricionária, fazendo uso da doutrina estrangeira destaca a diferença entre discricionariedade e arbitrariedade. Distingue ato vinculado, de ato discricionário e de ato arbitrário e analisa os elementos que compõem o ato. Passa então à análise da possibilidade de sujeição dos atos discricionários ao controle do judiciário, fazendo uso de doutrina estrangeira para dar suporte às suas conclusões. Passa finalmente à análise dos fatos concretos sob a ótica da teoria do desvio de finalidade.

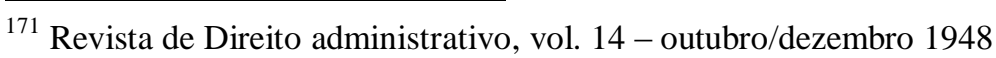




\subsubsection{Competência discricionária da Administração e controle judicial}

A Inspetoria Estadual de Trânsito decidiu estabelecer os horários em que deveriam circular os ônibus entre a cidade de São José do Mipibu e a capital Natal. Sustentou a Inspetoria que esse agir estaria amparado pela lei, já essa competência faria parte de suas atribuições legais.

Seabra Fagundes, em nenhum momento, discordou que era atribuição da Inspetoria de trânsito estabelecer os horários dos veículos de transporte coletivo de passageiros.

“A fixação de horários de tráfego dos veículos é, sem dúvida, atribuição discricionária das autoridades a quem incumbe a supervisão do transporte coletivo de passageiros..."

"Está certa, portanto, a Inspetoria de Trânsito quando sustenta enquadrar-se nas suas atribuições o prescrever horários a todos os serviços de ônibus neste Estado". ${ }^{172}$

Lembrou o eminente desembargador que esse era um dos setores da atividade administrativa onde a discricionariedade encontrava campo mais propício a se exercer; mas não deixou de destacar que competência discricionária nada teria a ver com arbítrio.

"A competência discricionária não se exerce acima ou além da lei, senão como toda e qualquer atividade executória, com sujeição a ela.

O que a distingue da competência vinculada é a maior mobilidade que a lei enseja ao executor no exercê-la, e não a liberação da lei.

Enquanto ao praticar o ato administrativo vinculado a autoridade está presa à lei em todos os seus elementos (competência, motivo, objeto, finalidade e forma), no praticar o ato discricionário é livre (dentro de opções que a própria lei prevê) quanto à escolha dos motivos (oportunidade $\mathrm{e}$ conveniência) e do objeto (conteúdo).

Entre praticar o ato ou dele se abster, entre praticá-lo com este ou aquele conteúdo (por exemplo: advertir apenas ou proibir), ela é discricionária.

Porém no que concerne à competência, à finalidade e à forma, o ato discricionário está tão sujeito aos textos legais como qualquer outro.

Até a possibilidade de agir sem competência, de negar o interesse público ou de violar as formas pretraçadas, não vai a faixa da oscilação deixada pelo legislador, sob o império das necessidades múltiplas e urgentes da vida

${ }^{172}$ RDA, p. 57. 
administrativa, ao Poder Executivo (nosso O Controle dos Atos Administrativos pelo Poder Judiciário, pp. 58-60)."173

Seabra Fagundes traz para o acórdão inúmeras citações de doutrina estrangeira, como é o caso de Goodnow ${ }^{174}$, Guido Zanobini ${ }^{175}$, Arthur W. Bromage ${ }^{176}$, José Gascón y Marín ${ }^{177}$, Fritz Fleiner ${ }^{178}$ Marcelo Caetano e Gabino Fraga Jr, para dar suporte às suas conclusões acerca da possibilidade de controle jurisdicional sobre os atos discricionários.

Em relação aos autores brasileiros, fez menção que o assunto relacionado ao exame dos atos discricionários pelo Poder Judiciário, não teria tido o "largo desenvolvimento que comporta" e citou autores que admitiriam a sujeição dos atos discricionários ao controle do judiciário: J. Matos de Vasconcelos (Direito Administrativo, vol. II, pp. 122-123), Tito Prates da Fonseca (Direito Administrativo, pp. 151-152), Castro Nunes (Do Mandado de Segurança, p. 133), e J. Guimarães Menegale (Direito Administrativo e Ciência da Administração, vol. II, pp. 304-306).

Após a análise da possibilidade do controle judicial sobre os atos discricionários, Seabra Fagundes chega ao ápice de sua abordagem, passando a analisar o ato sob a perspectiva de sua finalidade.

\footnotetext{
${ }^{173}$ Revista de Direito Administrativo, v.xxxx, p. 57-58

${ }^{174}$ A competência discricionária não autoriza, adverte Goodnow, 'tomar medidas arbitrárias, caprichosas, inquisitoriais ou opressivas' (Les príncipes du Droit Administratif des Etats Unis, p. 383).

${ }^{175}$ Guido Zanobini afirma peremptoriamente: "É importante distinguir o poder discricionário da liberdade em sentido comum (Dalle comune libertá). Enquanto esta última comporta verdadeiro arbítrio, segundo o qual o sujeito pode inspirar a sua decisão em qualquer motivo que considere oportuno, a discricionariedade é uma liberdade duplamente condicionada: de modo genérico, porquanto a Administração no seu exercício deve sempre agir da maneira que repute mais útil ao bem geral, isto é, aos interesses do Estado; e de modo específico porque ela, vez por outra, há de praticar ato de interpretação para indagar as razões pelas quais a lei lhe haja conferido o poder, o fim particular para cuja consecução o exercício dele deve ser dirigido, agindo do modo mais correspondente a tal fim". (Corso de Diritto Amministrativo, 1939, vol. I, pp. 95-96).
}

${ }^{176}$ Arthur W. Bromage refere que nos Estados Unidos o Poder Judiciário, em virtude da cláusula Due Processo f Law, examina amplamente os atos administrativos discricionários, coibindo os excessos manifestados no exercício do Police Power (State Government and Administration in the United States, p. 316)

${ }^{177}$ José Gascón y Marín faz sentir a existência de uma tendência moderna a limitar, pelas vias de controle a ação administrativa, mesmo quando discricionária. (Tratado de Derecho Administrativo, vol. II, pp. 213-214).

${ }^{178}$ Para Fritz Fleiner com a competência discricionária o legislador outorga à autoridade administrativa, determinar como cabível "entre as várias possibilidades de solução, aquela que melhor corresponda no caso concreto à intenção da lei". (...) "A exorbitância do poder discricionário constitui ato ilícito". Instituciones de Derecho Administrativo, pp. 117-119. 
Se entre os limites instransponíveis pela autoridade administrativa, está o concernente à finalidade (tantas vezes, aliás, como ressalta Roger Bonnard no seu precioso Droit Administratif, p. 34, quase confundida com o motivo), $\mathrm{o}$ ato que, encobrindo fins de interesse público, deixe à mostra finalidades pessoais, poderá cair na apreciação do Poder Judiciário, não obstante originário do exercício de competência livre.

Não é, pois a competência discricionária o bastante, por si só, a afastar o exame jurisdicional de qualquer ato administrativo, e com aplicação aos autos, o ato do sr. Inspetor de Trânsito acoimado de ilegal.

Sublinha Seabra Fagundes que a teoria do "détournement de pouvoir" naquela época já incorporada ao Direito Administrativo Francês, teve origem no caso de um prefeito ${ }^{179}$, que tendo atribuições para regular a circulação e permanência de veículo de passageiros e cargas, nas proximidades das estações ferroviárias, com o fim de bem ordenar o movimento no interesse público, usou de tal poder para conferir monopólio a certa empresa. Examinado o assunto pelo Conselho de Estado, este teve o ato como contrário ao direito, porque através dele se usara a competência outorgada na lei com uma finalidade diversa da prevista.

No caso em questão, Seabra Fagundes considerou, pela análise dos elementos probatórios, que o ato da administração que fixou o horário do terceiro ônibus do impetrante entre $10 \mathrm{~h}$ e $22 \mathrm{~h}$, apesar de praticado no exercício da competência legítima e de ter objetivo lícito, pecou por desvio de finalidade. Segundo ele, o órgão administrativo tinha em mente cercear a atividade do impetrante favorecendo o concorrente, e não, como era de se esperar, o atendimento do interesse público.

Considerou também, em seu voto, que era esse o único serviço de ônibus no Estado sujeito a horário pela Inspetoria (afirmativa do impetrante, não contestada), o que tornaria suspeito o zelo fiscalizador da autoridade, já que horários deveriam existir para todas as linhas e não só para essa.

O trecho abaixo transcrito explicita a ideia central do julgado:

\begin{abstract}
"Assente que nenhuma razão de interesse coletivo se apresentou para denegar o pedido da Empresa de Transporte Potiguar Limitada, vejamos o outro lado do problema, isto é, como a solução desatendeu a esse interesse e favoreceu terceiro."
\end{abstract}

${ }^{179}$ Caso "Lesbats", em 1864, já mencionado anteriormente na "parte 1" desta pesquisa. 
"E, assim vistos os dois aspectos, a conclusão da ilegitimidade do ato e da procedência do pedido se imporá". ${ }^{180}$

Em relação à teoria do desvio de poder, Seabra Fagundes invocou ampla doutrina estrangeira, citando Bonnard ${ }^{181}$, Bielsa ${ }^{182}$, Afonso Rodrigues Queiró ${ }^{183}$, Duguit ${ }^{184}$, Leonard White $^{185}$ e Fleiner ${ }^{186}$, além de outros.

De Castro Nunes, citado por Seabra Fagundes, é a afirmação: "Se patente a oposição entre a finalidade objetivada em concreto e a finalidade legal do ato, indevida terá sido a aplicação da lei, e, portanto, ilegal o ato". RDA, p. 68.

Seabra Fagundes finaliza seu voto concedendo o mandado de segurança "para que o impetrante possa trafegar o seu ônibus no horário solicitado, sem prejuízo, é claro, do exercício, pela Inspetoria, das atribuições genéricas que lhe confere a lei na disciplinação impessoal das condições de trânsito".

Vítor Nunes Leal, em comentário ao acórdão, fez referência, inicialmente, ao uso da expressão "ato discricionário", que, para ele não seria correta, uma vez que inexistindo discricionariedade em relação à competência, à forma e à finalidade, não seria possível falar-

\footnotetext{
${ }^{180}$ RDA, p. 72.

181 “Em matéria de fins não existe jamais para a Administração um poder discricionário. Porque não lhe é nunca deixado poder de livre apreciação quanto ao fim a alcançar. O fim é sempre imposto pelas leis e regulamentos, seja explícita, seja implicitamente. Assim é que, muitas vezes, o fim é implicado pela naturez do ato no sentido de que, dada a sua natureza, não pode ele objetivar outro fim”. (ob. Cit., p. 228). Revista de Direito Administrativo, p. 65.

182 O "fim legal", diz Bielsa em sentido idêntico, pode vir expresso ou apenas 'subentendido na lei' (vol. I, p. 122). RDA, p. 65.

${ }^{183}$ Mesmo porque toda vez que a norma legal atribui a um órgão uma função, "fá-lo na pressuposição de que esta função apenas será exercida quando no mundo das realidades certa ou certas situações de fato se verifiquem". (A Teoria do desvio de poder em Direito Administrativo, RDA, vol. VI, p. 60) RDA, p. 66.

${ }^{184}$ Duguit chega a entender que não basta processa a autoridade sob a inspiração de um fim qualquer de interesse público, sendo mister, para a validez do ato, que ao praticá-lo vise à finalidade específica, em virtude da qual lhe tenha sido outorgada a competência (Traité de Droit Constitutionnel, vol. II, pp. 381382). RDA, p. 66.

${ }^{185}$ Leonard White enumera, entre os casos que, nos Estados Unidos 'certamente reclamam correção judicial', aquele em que o funcionário usa a sua autoridade 'para prejudicar alguém por motivos de ordem privada' (ob. Cit., pp.0581-582).

186 Não são apenas as limitações extrínsecas que a autoridade tem de respeitar, senão também certas limitações internas que são impostas ao seu poder discricionário: à autoridade é proibido expedir ordem por capricho utilizando a sua competência; ao exercer aquele seu poder discricionário não pode impor o seu arbítrio em cada caso particular, mas, sim, atender aos fatores que a lei quer que se tenham em consideração. Juridicamente falando, o abuso do poder discricionário equivale a uma exorbitância dos limites legais.

O poder discricionário tem, nem mais nem menos, o escopo de tornar possível à Administração adaptar a sua atividade às exigências das circunstâncias individuais, de sorte que essa resulte sempre a mais eficaz e a mais útil ao fim público de que se trata. (ob. Cit.., pp. 119 e 96) RDA, 67-68.
} 
se numa entidade jurídica chamada ato discricionário. O correto, para ele, seria referir-se a poder discricionário. ${ }^{187}$

No conceito de Vitor Nunes Leal, "o princípio constitucional da separação de poderes, com outorga de toda a jurisdição formal ao Poder Judiciário, exige que se reserve à Administração uma zona própria, imune à intromissão dos juízes". Para ele, o sistema brasileiro, dificilmente, poderia admitir um conceito de desvio de poder tão amplo como o dos franceses, que envolveria, segundo Duguit, a abolição do poder discricionário.

"É preciso ter em conta, entretanto, que o Conselho de Estado francês é um órgão do contencioso-administrativo, faz parte da própria Administração, como instância jurisdicional. Pode permitir-se, portanto, maior amplitude na apreciação dos atos da chamada Administração ativa, pois é a própria Administração contenciosa que os revê". ${ }^{188}$

Segundo o mesmo comentarista do acórdão, não valeria também invocar o exemplo norte americano, já que nunca incorporamos à nossa doutrina e à nossa jurisprudência as consequências que a "construction" da Corte Suprema opera.

\begin{abstract}
Enquanto, nos Estados Unidos, a tradição colonial do common law, levada pelos ingleses e que conferia ao juiz um papel de co-criador do direito positivo, contribuía para dilatar a competência do judiciário após a independência, entre nós, a tradição imperial do direito escrito e da quase imunidade da Administração Pública em face do judiciário republicano a restringir sua interferência no campo da atividade administrativa. Certamente, trata-se, aqui, de fatos e não de princípios, mas em toda parte a tradição se incorpora, consciente ou inconscientemente, aos demais fatores determinantes dos princípios jurídicos, e o Brasil não constitui exceção. ${ }^{189}$
\end{abstract}

\title{
5.1.4. Conclusão
}

Baseado na teoria do desvio de poder/finalidade, Seabra Fagundes, no acórdão considerado o "leading case" brasileiro, mediante as provas produzidas nos autos, concluiu

\footnotetext{
187 In RDA, p. 60-61: “A existência, portanto de atos vinculados - assim designados com precisão conceitual - é, em parte, responsável pelo uso generalizado da incorreta expressão atos discricionários, que se opõem aos vinculados, mas que não existem na realidade...... A afirmação que nesse sentido fez o Desembargador Seabra Fagundes é incontestável, com a única diferença - terminológica e conceitual - de que, não existindo discricionariedade no que respeita a competência, à forma e à finalidade, não existe, consequentemente, uma entidade jurídica a que, rigorosamente, se possa dar o nome de ato discricionário."

${ }^{188}$ RDA, p. 71

${ }^{189}$ RDA, p. 78
} 
que a autoridade, a pretexto do exercício de um poder discricionário, pretendia favorecer uma empresa, em detrimento de outra. Não se vislumbrou razão nenhuma de utilidade pública, ou seja, nenhum benefício haveria aos usuários da referida linha; portanto, não se tratava, assim, do uso do poder discricionário, mas de um desvio de finalidade.

Nas palavras de Vitor Nunes Leal,

\begin{abstract}
"tratava-se de ação arbitrária, violadora do princípio constitucional da igualdade de todos perante a lei e que equivalia a transformar a administração pública em instrumento de concorrência desleal. Não estava em jogo simples acerto ou desacerto da medida: a opção administrativa contrariava princípios jurídicos pacificamente aceitos, com a manifesta intenção de favorecer um dos contentores numa luta comercial".
\end{abstract}

Celso Antônio Bandeira de Mello ${ }^{190}$, ao referir-se ao tema do desvio de poder, afirmou que o controle sobre ele é de estrita legalidade,

Tratando-se, como se trata, de um comportamento que desgarra do fim legal, é, em suma, uma transgressão da lei. Por isso o controle jurisdicional do desvio do poder é um controle de estrita legalidade. De modo algum agride a margem de liberdade administrativa, isto é, a discrição que a lei haja conferido ao agente.

Seabra Fagundes deixou claro em seu voto, que competência discricionária nada tem a ver com decisão arbitrária; procurou, assim, estabelecer uma linha de argumentação que conduzia para a possibilidade de o judiciário exercer o controle sobre os atos da administração, ditos discricionários.

A importância deste aresto foi também destacada por Carlos Mário da Silva Velloso na $7^{\mathrm{a}}$ edição do livro "O Controle dos Atos Administrativos pelo Poder Judiciário", aduzindo que, "o acórdão de Seabra foi pioneiro, no Brasil, na apreciação dos atos discricionários pelo Poder Judiciário. Até então, a discricionariedade era encarada como tabu e com fetichismo pelos Tribunais, que se recusavam a enfrentá-la. O Acórdão inovou na jurisprudência brasileira. $^{191}$

\footnotetext{
${ }^{190}$ Discricionariedade e Controle Jurisdicional, p. 57.

${ }^{191}$ Carlos Mário da Silva Velloso, Prefácio da $7^{\mathrm{a}}$ ed. De O Controle dos Atos Administrativos pelo Poder Judiciário, de Miguel Seabra Fagundes, 2005, p. VII/VIII.
} 


\section{Supremo Tribunal Federal}

Os Julgados do Supremo Tribunal Federal selecionados foram obtidos, em sua maioria, em consulta ao próprio "site" do Tribunal; à exceção de uns poucos que foram buscados na Revista de Direito Administrativo.

Ao todo, foram verificados mais do que os vinte e cinco acórdãos que estão reproduzidos no trabalho. Procurou-se agrupar os Julgados selecionados em temas ou situação histórica que lhes eram comuns, assim, o agravo de petição $n^{\circ} .9 .949$, de 16/9/1941, que foi disposto no item "ato discricionário praticado ao 'tempo em que o Governo esteve investido de todos os poderes"”, assemelha-se aos outros acórdãos, Agravo de Petição nº 12.210, Recurso Extraordinário n 19.720, Recurso Extraordinário - embargos- $n^{\circ} 21.541$ e Mandado de Segurança $n^{\circ} 18.671$, pois se relacionam a atos praticados em períodos históricos com características semelhantes.

Dá bem a ideia do subjetivismo que cercava os atos administrativos praticados nesse período, o parecer do Consultor-Geral da República, de 6 de setembro de 1966, no mandado de segurança $\mathrm{n}^{\circ} .18 .671 \mathrm{em}$ face de ato demissional fundado no Ato Institucional de 9.4.1964:

"não se trata de aplicação de pena perpétua, mas, sim, do reconhecimento de intransponíveis incompatibilidades entre o cidadão e o Serviço Público. Este só poderá ser exercido por aquele, quando tais incompatibilidades já não existirem. Não é possível prever-se prazo. É um estado de espítrito.”

Os demais Julgados estão inseridos em itens relacionados a servidor público, desapropriação, extradição de estrangeiro e processo licitatório. 
6.1. Ato discricionário praticado ao "tempo em que o Governo esteve investido de todos os poderes"

\subsubsection{Agravo de Petição no 9.949 - São Paulo - 16/09/1941 - 2a . Turma}

Ato administrativo discricionário praticado ao tempo em que o governo esteve investido de todos os poderes - Aplicação do artigo 18 das disposições transitórias da Constituição de 1934.

Trata-se de caso em que um Juiz Federal propôs, perante o Juízo dos Feitos da Fazenda Nacional, ação ordinária contra a União Federal para haver diferença de vencimentos, por ter sido aposentado administrativamente em 5 de dezembro de 1932, como pena pela participação que lhe foi atribuída no movimento revolucionário de 9 de junho de 1932.

A aposentadoria fora concedida sem nenhuma motivação e, contra ela, o Autor apresentou reclamação à Comissão Revisora que emitiu parecer no seguinte sentido:

Concluiu que o ato de afastamento do A. por meio de aposentadoria compulsória só teve por objetivo punir o Reclamante em virtude de sua participação no movimento revolucionário de 1932, e, consequentemente, pelo citado preceito constitucional (art. 19 das Disposições Transitórias da Constituição de 1934) já não tem existência jurídica, não se justificando que ainda subsistam de fato os efeitos de pena que lhe foi imposta com a aposentadoria compulsória, já extintos de direito; e, por fim, opinou pelo aproveitamento do A. no mesmo cargo de Juiz Federal na Seção de S. Paulo, de que fora afastado.

A União contestou, havendo réplica e tréplica. A sentença de primeiro grau considerou o autor carecedor da ação, o que levou o A. a interpor recurso de agravo.

O voto do Ministro José Linhares, como Relator do processo, referiu-se ao ato de aposentação compulsória como "ato administrativo praticado pelo Governo no período discricionário". Sublinhou o Ministro que se tratava de ato meramente discricionário, praticado por um governo de fato, aprovado pela Constituição Federal e que não podia ser 
apreciado pelo Poder Judiciário. De acordo com José Linhares, "num período anormal de governo de fato a ninguém é lícito invocar garantias constitucionais, porque o fundamento da inconstitucionalidade do ato não tem qualquer significação no caso, uma vez que todos os poderes estão enfeixados na mão de uma só pessoa".

Expressa também o sentimento dos Ministros sobre esse período, o que disse o Ministro Orosimbo Nonato, em seu voto, “este foi um ato do Governo Discricionário; logo, é maior de qualquer censura judiciaria".

Os Ministros do Supremo Tribunal Federal, em sessão da segunda turma julgadora, por unanimidade de votos, negaram provimento ao recurso para confirmar a decisão de primeira instância. Ficou explicitado neste acórdão que não caberia ao Judiciário rever o ato praticado pela Administração.

\subsubsection{Agravo de Petição no .12 .210 - Distrito Federal - 28/5/1945 - $1^{\text {a }}$. Turma}

O reformado ou aposentado pelo art. 177 da Constituição não pode pretender a revisão do ato do governo do ponto de vista da conveniência ou da oportunidade da medida adotada, ainda que injusta.

Cuida-se de ação em que o autor, Capitão Médico do Exército, tendo sido demitido em 1926, propôs ação para ser reintegrado, obtendo decisão favorável. Em maio de 1939, por ato do governo, foi reformado compulsoriamente. O motivo declarado para o ato foi: que não era conveniente a sua permanência na ativa, não só por efeito de seu longo afastamento, como porque iria prejudicar a promoção de colegas do mesmo quadro. A reforma compulsória deuse com fundamento no art. $177^{192}$ da Carta Política de 1937 e Lei Constitucional no ${ }^{\circ}{ }^{193}$.

Inconformado, propôs ação para anular o ato de sua reforma, contestando os motivos que a informaram. Foi julgado carecedor de ação, tendo em vista que o ato em questão, a

\footnotetext{
${ }^{192}$ Art 177 - Dentro do prazo de sessenta dias, a contar da data desta Constituição, poderão ser aposentados ou reformados de acordo com a legislação em vigor os funcionários civis e militares cujo afastamento se impuser, a juízo exclusivo do Governo, no interesse do serviço público ou por conveniência do regime.

${ }^{193}$ Artigo único. Fica restabelecida, por tempo indeterminado, a faculdade constante do art. 177 da Constituição de 10 de novembro de 1937.
} 
conveniência do afastamento do servidor, seja militar, seja civil, é de exclusiva apreciação do Governo, não podendo o Judiciário reexaminar os motivos em que o ato tenha se fundado.

O Ministro Castro Nunes, Relator, em seu voto, declarou insuscetível de exame judicial a motivação do ato do afastamento fundado no dispositivo constitucional invocado. Segundo o Ministro, "o reformado ou aposentado pelo art. 177 não pode pretender a revisão do ato do Governo do ponto de vista da conveniência ou oportunidade da medida adotada, ainda que injusta".

Negaram provimento, por votação unânime.

\subsubsection{Recurso Extraordinário no 19.720 - Distrito Federal - 17/6/1952 - 2a. Turma}

Neste acórdão, o Ministro Orosimbo Nonato, Relator, trata da questão do desvio de poder na edição do ato administrativo questionado e de sua motivação.

Conforme consta do relatório, o Tribunal Federal de Recursos decidiu que 'na vigência da Lei Constitucional $\mathrm{n}^{\circ}$. 2, de 16 de maio de 1938, podia o Governo aposentar funcionários civis cujo afastamento se impusesse a juízo exclusivo da Administração, no interesse do serviço público ou por conveniência do regime'. Houve embargos que, no dizer do Ministro, ‘tiveram êxito feliz’ e cujo acórdão foi assim ementado:

"Ementa: Aposentadoria no interesse do serviço público. Ato discricionário e ato de império; distinção. Ao contrário do ato de império, o ato discricionário não escapa à apreciação funcional do Poder Judiciário. Quando motivado, ou quando a lei o permite por motivos reais ou menos definidos, o ato discricionário pode ser aquilatado em razão desses motivos determinantes. Falhando ou inexistindo a causa, é ilegal o ato."

O Ministro faz uma explanação detalhada sobre o ato discricionário, citando inúmeras fontes para dar suporte ao seu pensamento e se posiciona, afirmando que "o reconhecimento da existência do ato discricionário não importa o da existência de uma 'órbita do abuso', de um 'campo de ilimitada expansão, onde a autoridade possa matar a fome de arbítrio ou saciar a sede da violência', como se exprime Nogueira Itagiba (O Pensamento Político Universal e a Const. Bras., vol. I, pág. 637). 
Vislumbra a possibilidade de freio ao ato administrativo discricionário, invocando a teoria do desvio de poder. Segundo o Ministro, o ato discricionário está "sujeito a temperamentos que possam derivar do 'détournèment de pouvoir"'.

"A só limitação, pois, que se arma contra a expansão do ato discricionário é a vedação do desvio de poder, aplicação, no campo administrativo, da doutrina do abuso de poder, com a qual, entretanto, não se confunde inteiramente."

“O 'détournément de pouvoir' que se pode opor aos desmedimento no exercício do ato discricionário é um caso especial de excesso de poder, de extralimitação, como diz Fleiner (Der. Ad. Trad. Espanhola, p.119)..”

Não obstante, adverte, porém, que isso é certo em linha de princípio, mas, o juiz deve proceder com cautela na análise da prova dos extremos do excesso do poder.

Ao referir-se ao caso concreto afirmou que não seria possível desconhecer a situação política em que o princípio constitucional fora estabelecido, representando para o Executivo, arma de usos amplíssimos, em nome da conveniência da administração e do regime novo que se criava. Afirmou, ainda, que "no julgamento da possibilidade da adaptação dos funcionários a esse regime diferente foi que se reservou ao Executivo função que excluia a intervenção de outros poderes".

Citando Velasco (liv. cit., pág. 158 in fine), afirma que, "em tais casos é possível falar em 'discricionalidade absoluta, cuando los actos se abandonan íntegramente al arbitrio do Poder ejecutivo, el cual, entonces, solamente provoca responsabilidades políticas".

O Ministro, embora tendo consciência de que o regime sobre o qual o ato administrativo foi editado não mais perdura, entende o ato como fato consumado, mesmo após o advento do novo regime que estabeleceu garantia e definiu direitos.

É certo, ainda, que aquele regime não perdura, voltando-se a um sistema de garantias a cidadãos e a funcionários que lutam area por area com aquela 'discricionalidad absoluta'.

Tratava-se, porém, quando do advento do novo regime, de fato consumado que, na melhor censura de direito, fica sobranceiro à retroatividade, ainda da lei que estabelece garantia e define direitos.

Entretanto, conforme destaca o Ministro, a aposentadoria foi fundamentada em processos, cuja numeração foi expressamente mencionada, mas verificou-se que tais processos não existiam, que não foram instaurados inquéritos administrativos. 
Vislumbrou o Ministro, a aplicação da teoria dos motivos determinantes, ainda que não expresso por ele. Entendeu o Ministro que se o ato tinha como base aquilo que se apurou em processo administrativo e, já que esse processo não existia, o ato teria como fundamento o nada.

Se o ato mesmo discutido apresenta como base o que consta de determinado processo (verbis, tendo em vista o que consta...) e se este processo inexiste, o ato se mostra materialmente incompleto e apresenta como fundamento o nada.

$\mathrm{O}$ ato discricionário está sujeito, também, ao requisito da forma (vêde Seabra Fagundes, O Controle dos Atos Adm. $2^{\mathrm{a}}$ ed., p. 95, citando Aurelino Leal, Ruy Barbosa..) e demais disso, aludindo a fundamento que constaria do processo (tendo em vista o que consta) apresentou causa fóra do exercício do poder discricionário.

O Ministro conheceu do recurso e negou provimento ao apelo da União Federal.

O Ministro Luiz Gallotti, por sua vez, deu provimento ao recurso da União, afirmando coerência com seus pronunciamentos anteriores.

Ao expressar seu voto, asseverou Luiz Gallotti que, caso o ato tivesse como fundamento falta apurada em processo existente e, nesse processo nada constasse contra o aposentado, aí ele estaria de acordo com o Ministro Orosimbo Nonato. Entretanto, no caso em tela, a referência feita a processo inexistente, significa que essa numeração era apenas mera formalidade burocrática, significando, apenas, que a autoridade utilizou sua faculdade discricionária, outorgada pela Constituição de 1937.

Luiz Gallotti conheceu e deu provimento ao recurso da União.

A Turma conheceu do recurso por unanimidade, mas negaram-lhe provimento contra o voto do Ministro Luiz Gallotti.

6.1.4. Recurso Extraordinário - embargos- no 21.541 - Distrito Federal - 25/06/1954 - 1 . Turma 
Neste recurso o Ministro Mario Guimarães, Relator, faz menção aos motivos determinantes do ato, que hoje considera-se como aspecto elementar; sem, contudo, entender sua aplicação ao caso concreto.

EMENTA - No domínio da Constituição de 1937, a aposentadoria concedida na conformidade do art. 197, alínea a, do Estatuto dos Funcionários Públicos dependia do juízo exclusivo do Presidente da República, que não precisava, por forma alguma, justificar seu ato.

Neste recurso foi analisado o caso em que o funcionário dos Correios e Telégrafos de São Paulo, que ocupava o cargo de tesoureiro, foi aposentado compulsoriamente por ato do Presidente da República, datado de 19/03/1945, com base no art. 197, alíena a, do Dec. Lei 1.713 , de 28/10/1939.

Para anular esse ato foi proposta ação, julgada procedente em $1^{\mathrm{a}}$ instância. A União apelou e teve o seu recurso provido, com a seguinte ementa: "Na vigência da lei constitucional $\mathrm{n}^{\circ} 2$, de 1938 , podia o Governo aposentar funcionário público na forma do art. 197, do Dec. Lei 1.713, de 1939”. O apelado ofereceu embargos que foram acolhidos pelo Tribunal pleno. Manifestou a União recurso extraordinário ao qual foi negado provimento. Embargou a União, insistindo que o ato do Sr. Presidente da República era de puro arbítrio e não precisava ser justificado.

O Ministro Mario Guimarães, em seu voto, diz que o caso versa sobre uma aposentadoria concedida em pleno período discricionário e referindo-se à legislação que deu suporte ao ato, afirmou: "os termos da lei são peremptórios - juiz da conveniência seria o Sr. Presidente da República".

Segundo ele, "procura-se arrimar o venerando aresto em princípio de Direito Administrativo, que tolera se examine a procedência dos motivos nos atos discrecionários, quando esses motivos são explicitados na decisão, Aceito, in principio a tese jurídica, para cujo apoio se podem invocar algumas autoridades". Para ele, não seria possível aplicar essa regra no caso dos autos; ela só teria aplicação se o Governo invocasse uma razão e essa razão se mostrasse inexistente.

O Ministro destacou que o decreto de aposentadoria apresentava os seguintes termos: “O Presidente da República resolve aposentar, no interesse do serviço público, de acordo com o artigo 197, alínea a, do decreto lei 1913, de 28 de outubro de 1939: Tendo em vista o que 
consta do processo $\mathrm{n}^{\mathrm{o}}$ 4.979, de 1945, do Departamento de Administração do Ministério da Viação e Obras Públicas: Eduardo Ibirocahi”.

De acordo com o Ministro, o Presidente não abdicou do arbítrio que lhe conferia a lei, no julgamento do inquérito administrativo. Afirmou também que a autoridade não declinou fatos sobre os quais assentasse o seu pronunciamento, caso em que, então sim, se poderia demonstrar que tais fatos não haviam ocorrido. O fato da alusão a um processo e de não terem sido trazidos tais documentos para os autos, acredita que tais referências não seriamm mentirosas, afirmando,

\footnotetext{
"Que descesse a imoralidade administrativa a termos de citar a maior autoridade da nação um processo que não existisse e lhe dar um número imaginário". Afirmou ainda, que "o que se apurou nesse processo, não é do nosso julgamento. Não disse a autoridade quais as razões que a moveram. A única apresentada - a existência de um inquérito, não se provou que fosse falsa. Pode, pois, ter havido injustiça na aposentadoria do embargado. Ilegalidade, data venia não a vejo".
}

O Ministro Nelson Hungria, revisor, no mesmo sentido, afirmou que o seu voto na Suprema Côrte foi sempre no sentido de que essa aposentadoria compulsória com base no artigo 197 do antigo Estatuto dos Funcionários Civis, reproduzindo o artigo 177 da Constituição de 1937, cujo prazo de limitação fora excluído pela Lei Constitucional $n^{\circ}$. 2, de 1938, “escapa à apreciação do Poder Judiciário, ainda no caso em que o Presidente da República, a cujo juízo exclusivo era subordinada tal aposentadoria, formulasse motivação ou se baseasse, ex abundantia, em processo administrativo real ou suposto".

Sublinha o Ministro que, se tanto o interesse do serviço público quanto a conveniência do regime, ficavam a exclusivo juízo da autoridade; a aposentadoria compulsória mais que um ato discricionário era ato puramente arbitrário e, portanto, livre de qualquer critério objetivo sujeito à censura do Poder Judiciário.

Nelson Hungria entendeu que seria inaplicável a teoria do detournement de pouvoir ou do eccesso di potere, dos direitos francês e italiano, vez que se aceitos, estaria cancelada a cláusula 'a juízo exclusivo do Presidente da República'. Prossegue no seu entendimento, afirmando que , 
Nem posso assentir na tése de que um ato que póde ser praticado arbitràriamente deixe de $\mathrm{o}$ ser porque a autoridade competente entende de motivá-lo ou de fundamentá-lo em processo ou inquérito administrativo.(sic)

Finaliza, afirmando que "a motivação ou fundamentação é inteiramente ociosa ou supervacânea, não podendo jamais importar em renúncia, no caso concreto, da prerrogativa constitucional ou legal. (.....). Uma excrescência ou superficialidade não prejudica a essencialidade".

Diversamente, o Ministro Hahnemann Guimarães para sustentar o voto vencedor na Segunda Turma e por divergir do relator e revisor, rejeitando os embargos da União, fez referência à decisão da Segunda Turma, que, por sua vez, confirmara a decisão do Tribunal Federal de Recursos, já que o Tribunal entendeu que "a disposição do art. 197 do Dec.lei no 1.713, de 28 de outubro de 1939, devia ser aplicada, quando ocorressem os casos nela previstos, e ao Poder Judiciário competia, assim, verificar se ocorreram os casos em que era lícito ao Presidente da República aposentar o funcionário pela conveniência do regime ou no interesse da administração".

Entendeu o Tribunal Federal de Recursos que a aposentadoria fora ilicitamente concedida, já que não ocorria nenhum dos casos previstos na citada disposição do art. 197; conclui, então, que merecia confirmação o acórdão impugnado, negando provimento ao recurso da União.

O Ministro Ribeiro da Costa, afirmou que tem sustentado em seus votos, nas análises de matérias análogas "que quando o Presidente praticava o ato de aposentadoria e este estava condicionado à observância do preceito legal, cabe à Justiça examinar o aspecto formal, o aspecto legal do ato". Rejeitou os embargos.

Os embargos, entretanto, foram recebidos pelo Pleno, contra os votos dos Ministros Hahnemann Guimarães, Ribeiro da Costa e Orosimbo Nonato.

\subsubsection{Mandado de Segurança no 18.671- Distrito Federal - 6/6/1973 - Tribunal Pleno}

Mandado de Segurança - Não revisto ato de demissão fundado no Ato Institucional de 9.4.1964, inexistente direito líquido e certo a ser protegido por mandado de segurança, diante do entendimento da Administração, de que, por permanecer a incompatibilidade antes 
considerada, o servidor demitido não satisfaz requisito legal para o novo ingresso na função pública. Indeferimento do pedido.

Trata-se de caso emblemático, em que se discutia ato do Presidente da República tendo por base o Ato Institucional de 9.4.1964.

O impetrante, embora classificado em $13^{\circ}$ lugar entre os concursados de todo o território nacional e tendo recebido o certificado de habilitação em 28/03/1967 não foi nomeado pelo Presidente da República, quando do decreto de nomeação dos demais candidatos aprovados.

Nas informações prestadas, o Presidente da República asseverou que o impetrante já havia exercido, anteriormente, cargo de Agente Fiscal do Imposto de Renda, tendo sido demitido por força do Ato Institucional de 9 de abril de 1964. Segundo ele a improcedência do pedido era manifesta, pois não teria sentido a demissão do requerente de um cargo pelo Governo revolucionário para, por força de concurso, voltar a preencher esse mesmo cargo, por ato desse mesmo Governo revolucionário. Tal somente seria possível se se reconhecesse a inconveniência do seu afastamento anterior em processo regular, nunca por via de ação exclusiva do impetrante.

Interessante destacar o parecer do Consultor-Geral da República, de 6 de setembro de 1966, em que se pode perceber o extremo subjetivismo de que se cercava o ato questionado.

"não se trata de aplicação de pena perpétua, mas, sim, do reconhecimento de intransponíveis incompatibilidades entre o cidadão e o Serviço Público. Este só poderá ser exercido por aquele, quando tais incompatibilidades já não existirem. Não é possível prever-se prazo. É um estado de espítrito.”

Para o Presidente da República esse seria o entendimento em consonância com o período histórico da vida nacional. "A mudança de velhos hábitos, o combate à corrupção administrativa e a eliminação de movimentos subversivos não prosperariam se a Revolução não pudesse limpar a área, no serviço público, afastando a quantos fossem incompatíveis com tais objetivos".

No mesmo sentido, recheada de subjetividade, é a manifestação da Procuradoria Geral da República: 
"Na verdade, a demissão sofrida pelo impetrante, do mesmo cargo de fiscal em que agora pretende se investir, ocorrida em passado bem recente, ainda perdura a prova da relevante incompatibilidade para com o serviço do Fisco. ..... À Administração, no caso, há de ficar reservado o direito de acautelar-se em seus interesses, prevenindo-se contra o retorno a seu serviço de quem demonstrou, no exercício do mesmo cargo, uma incapacidade moral oportunamente apurada e que recomendou o seu afastamento."

Interessante comentar que o relatório ocupou seis folhas do acórdão e o voto do Ministro Eloy da Rocha ocupou apenas dois terços de uma página. Segundo o Ministro, a demissão seria insuscetível de controle jurisdicional, citando o parágrafo $4^{\mathrm{o}}{ }^{194}$ do artigo $7^{\circ}$ do Ato Institucional, bem como os artigos 173 e 181 das Constituições de 1967 e 1969, respectivamente.

Finalizou afirmando que inexistiria direito líquido e certo, já que o ato decorrente da demissão não foi revisto, diante do entendimento da Administração de que não fora preenchido o requisito legal para novo ingresso na função pública, uma vez que permaneceria a incompatibilidade do servidor.

A introdução desses julgados, justifica-se pelo valor histórico e para um confronto com os dias atuais, pela total incompatibilidade com os princípios constitucionais que vigoram hoje no país, com a Constituição de 1988.

6.2. Ato administrativo relacionado à demissão, admissão, remoção, aposentadoria, reforma ou promoção de servidor público

6.2.1. Mandado de Segurança ${ }^{\circ}$. 1.103 - Distrito Federal - $1^{\circ} .12 .1949$ - Pleno

Destaque-se que este mandado de segurança $n^{\circ} .1 .103$ e os embargos $n^{\circ}$. 7.307, a seguir analisado, foram dois dos acórdãos trazidos pelo Professor Roger Stiefelmann Leal, no livro "Memória Jurisprudencial - Ministro Orozimbo Nonato", editado pelo Supremo Tribunal Federal, em homenagem ao Ministro.

$194 \S 4^{0}$ - O controle jurisdicional desses atos limitar-se-á ao exame de formalidades extrínsecas, vedada a apreciação dos fatos que o motivaram, bem como da sua conveniência ou oportunidade 
Ementa: Nenhum princípio constitucional é violado na transferência compulsória de oficiais superiores da Armada para a reserva remunerada, segundo indicação do Conselho de Almirantes.

De acordo com o relatório, os Capitães de Mar e Guerra M. e E., requereram mandado de segurança que lhes fosse assegurado o direito líquido e certo à permanência no serviço ativo. Pelos decretos de $n^{\circ}$ s. $475-\mathrm{J}$ e $475-\mathrm{L}$, os requerentes foram transferidos para a reserva remunerada. Foram também os requerente proibidos do uso dos recursos normais contra a resolução do Conselho de Almirantes, "que não só escolhe, entre os capitães de mar e guerra, os que julga menos aptos, indicando-os à transferência compulsória para a reserva remunerada, mas também decide, em definitivo e mesmo processo, o recurso oposto à sua decisão". Foram, ainda, privados de conhecer os motivos da decisão, e, assim, impedidos de refutá-los, bem como, permaneceram secretas as razões contrárias ao recurso que fora interposto.

O Ministro Hahnemann Guimarães, em seu voto, afirmou que as transferências compulsórias para a reserva remunerada, admitidas pelo artigo $9^{\circ}$. do dec. Lei $n^{\circ} .2 .173$, eram necessárias para que fosse possível as promoções exigidas para a renovação dos Quadros de Oficiais do Corpo da Armada. Afirmou, ainda, que,

A competência dada ao Conselho para decidir em última instância qualquer recurso apresentado contra suas deliberações (cit. Art. 10, par. $4^{\circ}$.), tem por objeto impedir que as razões determinantes da indicação feita pelo Conselho de Oficiais Gerais sejam anuladas, em outra instância, por motivos menos inspirados no interesse pela eficiência da corporação.

Concluiu o Ministro que a transferência havia sido perfeitamente legal e "não se contrariaram os princípios constitucionais de igualdade perante a lei, da intangibilidade do direito adquirido, do remédio judiciário para qualquer lesão do direito individual e da natureza contraditória da instrução criminal, em que se assegura aos acusados plena defesa", negando o mandado.

O Ministro Ribeiro da Costa, divergindo do Relator, sublinhou que o decreto lei $\mathrm{n}^{\circ}$. 2.173 estabeleceu um critéio arbitrário para a exclusão de oficiais do quadro da Armada Nacional, admitindo que um Conselho escolhesse livremente, independente de um julgamento, aqueles que seriam excluídos dos quadros ativos. 
Para o Ministro Ribeiro da Costa, o decreto lei $\mathrm{n}^{\circ}$. 2.173 seria incompatível com o artigo 182 da Constituição (de 1946), que assegurava aos oficiais a plenitude das suas patentes. Concedeu a Segurança.

O Ministro Hahnemann Guimarães, em aparte, ao discordar do Ministro Ribeiro da Costa, considerou que

seria, evidentemente, um excesso de individualismo, seria levar a extremos intoleraveis a proteção do direito individual, se ela se opuzesse a que as Fôrças Armadas tivessem aprimorada a sua eficiência pela necessária trânsferência de oficiais para a Reserva, quando não bastem as vagas ocorridas para a realização das promoções. (sic)

Ao apreciar a controvérsia, o Ministro Orosimbo Nonato apontou o abuso no "indevassavel sigilo" do critério de escolha para a aposentadoria compulsória, dizendo,

É verdade que o critério de escolha cerca-se de indevassavel sigilo. O eminente sr. ministro Relator demonstrou que os almirantes, juízes, no caso, referem-se a fatos que a ata não reproduz. Trata-se de deliberação que não envolve condenação criminal, mas um decesso. E o recurso contra essa deliberação que não envolve condenação criminal é, como disse o ilustre advogado, uma irrisão, porque a parte deconhece as razões que a inspiraram e, assim, esgrime como um fantasma, co uma sombra, pois que não se lhe dão pontos de referência para o debate.

Entendeu o Ministro, neste caso, que teria sido violado o princípio da inafastabilidade do controle judicial, "a meu ver, o princípio ofendido é o do 'controle' do Judiciário. Os oficiais que sofrem lesão em face da deliberação do Conselho não teriam recurso para o Judiciário".

Completa seu pensamento destacando que, sendo indeclarado o critério de escolha não permite aos oficiais saberem quais os motivos que serviram de base para a aposentadoria compulsória, bem como, torna o recurso inútil, já que inexiste base que o fundamente.

Não havendo recurso para o judiciário, a lesão de direito ficará invingada. O critério aqui não é tarifário, objetivo, mas, sim, subjetivo e indeclarado. Se o oficial é atingido pelo descesso, não sabe quais os motivos subjetivos que pelejaram em favor de sua transferência para a Reserva. 
Na Hipótese, o recurso administrativo seria inútil, já que a parte não tem ponto de referência para fundamentar o apêlo.

Por este só fundamento, é que concedo o mandado."

O Ministro Annibal Freire, que também votou pela concessão da Segurança, ao manifestar-se acerca da controvérsia, vislumbrou que resulta desse decreto lei um "julgamento de consciência", em antagonismo com o sistema constitucional.

(..)não há aferição alguma do valor da eficiencia, da capacidade técnica do oficial. Ocorrerá fatalmente a influência de fatores de ordem subjetiva. Trasnferiu-se, portanto, a um órgão da administração da Marinha a apuração da sorte dos oficiais superiores da mesma fôrça.

Resulta iniludivelmente da lei a instauração de um julgamento de consciencia que sobressalta o pensamento jurídico e se põe em antagonismo com o sistema constitucional.

Destacou o Ministro ademais, que a decisão do Conselho se reveste de caráter absoluto, já que seria o próprio Conselho que julgaria, em caráter definitivo, eventuais recursos. Quanto ao sigilo dos motivos determinantes da transferência dos Oficiais, assevera tratar-se de "regimen de defesa coator do patrimonio juridico".

Ao referir-se ao parágrafo $4^{\circ}$ do artigo 10, pelo qual caberia ao Conselho decidir em definitivo qualquer recurso apresentado, sublinhou tratar-se de decisão com caráter de absoluta, o que contrastaria com os preceitos Constitucionais. Asseverou que, "mesmo no regimen da Constituição de 1937, este Tribunal jamais admitiu a prevalência de dispositivos que infirmassem a autoridade do judiciário em decidir questões que não fossem de natureza essencialmente política” (sic).

Finalizou seu voto, comparando o caso em tela com o julgado em outro mandado de segurança, afirmando que o conteúdo jurídico seria o mesmo, ou seja, julgamento por livre convicção e coerção do direito de defesa.

A decisão, por maioria, entendeu por legítima a resolução adotada pelo Conselho de Almirantes e foi pelo indeferimento da Segurança, contra os votos dos Ministros Ribeiro da Costa, Edgard da Costa, Orosimbo Nonato e Annibal Freire. 


\subsubsection{Embargos na apelação Cível no 7.307 - 20/12/1944}

Ato administrativo - exame de sua validade pelo Poder Judiciário - demissão de funcionário público - confronto da prova produzida em inquérito administrativo e em processo judicial.

O autor da ação, ora embargante, propôs ação para anular ato de sua demissão. Segundo consta do relatório, o autor era telegrafista da Estrada de ferro Oeste de Minas e exercia as funções de agente de uma estação, quando agrediu o encarregado do serviço telegráfico, em razão de ter este levado ao conhecimento da empresa uma falta anterior dele, agressor. No curso da ação procurou dar uma versão diferente do fato, isto é, que ele é que fôra agredido, tendo, apenas se limitado a revidar a essa agressão e que o fato não se passara dentro da estação, mas fora desta.

O Juiz dos Feitos deu-lhe ganho de causa, considerando prevalente a versão apurada judicialmente e que a falta não teria sido tão grave a ponto de justificar a demissão. Julgou procedente a ação com pedido de reintegração. Houve apelação da Fazenda, tendo-lhe sido dado provimento. Ao acórdão opõe o autor os embargos.

A controvérsia que se instala é muito interessante, qual seria o limite que o Judiciário deveria observar ao julgar as demissões de funcionários. Poderia examinar os motivos que serviram de fundamento ao ato, ou ficaria adstrito o exame apenas aos aspectos formais?

O Ministro Castro Nunes, em seu voto, coloca a questão da seguinte forma:

\footnotetext{
"em que limites se deverá mover o Judiciário no julgamento das demissões dos funcionários ou, de um modo mais geral, na apreciação dos atos administrativos quando argüidos de ilegais. Estará adstrito somente aos aspectos formais do ato e da competência da autoridade? Ou a sua ação restauradora poderá ir além, alcançando a imputação na sua existência mesma, na sua prova, no seu relevo, de modo a lhe permitir, tais sejam os característicos da espécie, a aplicação da penalidade administrativa correspondente aos fatos apurados?"
}

$\mathrm{Na}$ apelação, o relator Ministro José Linhares, apoiado que foi pelo Ministro Bento de Faria, expôs o entendimento de que o exame da legalidade se circunscreve aos aspectos formais do ato. Em sentido contrário, os Ministros Orozimbo Nonato e Goulart de Oliveira, para os quais a ação reparadora dos tribunais não se confinaria em limites tão estreitos. 
Citando a Lei $\mathrm{n}^{\circ}$. 221, de 1894, Castro Nunes afirma que ela conferiu ao Judiciário poderes muito amplos na apreciação dos atos administrativos quando dispôs:

\begin{abstract}
"Consideram-se ilegais os atos ou decisões administrativas em razão da não aplicação ou indevida aplicação do direito vigente". "A autoridade judiciária fundar-se-á em razões jurídicas, abstendo-se de apreciar o merecimento dos atos administrativos sob o ponto de vista de sua conveniência ou oportunidade". "A medida administrativa tomada em virtude de uma faculdade ou poder discricionário somente será havido por ilegal em razão da incompetência da autoridade respectiva ou do excesso de poder."
\end{abstract}

Para Castro Nunes, então, a apreciação do mérito interdita ao Judiciário seria apenas a que se relaciona à conveniência e a oportunidade da medida. Estariam de fora dessa apreciação o merecimento por outros aspectos que pudessem configurar uma aplicação falsa, viciosa ou errônea da lei ou regulamento; hipóteses que se enquadrariam, segundo ele, de modo geral, na ilegalidade por "indevida aplicação do direito vigente".

Ao concluir seu voto, afirma que somente escaparia ao exame do Judiciário o aspecto do ato relacionado ao seu conteúdo ou merecimento, em se tratando de medidas de caráter discricionário, que só poderiam ser anuladas por incompetência da autoridade ou se alguma formalidade prescrita na lei tiver sido preterida, limites não discricionários. Assim, não seriam somente os aspectos formais do ato que autorizariam o exame judicial. Para ele, essa limitação so existe em se tratando de ato discricionário, que não poderia ser o de punição disciplinar do funcionário ou a sua destituição nos casos em que esta só é autorizada mediante inquérito administrativo.

Quanto ao exame do caso concreto, Castro Nunes destacou: o autor era funcionário de péssimos precedentes, nada menos que 16 punições disciplinares aplicadas a partir de 1912 e subsequentemente até as vésperas da demissão. Dessa forma, rejeitou os embargos ofertados pelo autor.

O Ministro Orosimbo Nonato, em sentido contrário, questiona se a existência do inquérito administrativo põe fim à questão da justiça da pretensão da parte, ou se pode ela, vencida naquela esfera, voltar-se ainda para o Poder Judiciário e demonstrar que a formalização do ato não se encontra no mesmo nível de sua justiça intrínseca. 
No voto dado na apelação, Orozimbo Nonato deixou claro que a demissão de funcionário depende da apuração de falta grave e a ocorrência desse requisito, o julgamento das provas neste sentido se produzem.

Orozimbo Nonato não aceita que, na apreciação do ato administrativo, deva o juiz limitar-se a verificar a formalização, não entrando no mérito da decisão impugnada. Entende o Ministro que não deve o Poder Judiciário limitar-se a apreciar o ato administrativo do ângulo visual de legalidade extrínseca e sim de seu mérito intrínseco, ou seja, de sua justiça ou injustiça.

\title{
Reforça Orozimbo Nonato que ao
}

\begin{abstract}
"Poder Judiciário é que compete, principalmente, decidir o direito que a parte oponha à administração baseada em lei do país. Quem dirá se o ato foi justo ou injusto: a própria administração, acobertada por um inquérito formalmene perfeito, ou, ao cabo de contas, o Poder Judiciário? A minha resposta é que cabe ao Poder Judiciário, porque a este compete, especificamente, resolver as pendencias, as controvérsias que se formem entre cidadãos ou entre o cidadão e o Estado."
\end{abstract}

Complementa afirmando que o Poder Judiciário ao analisar e julgar as provas, verifica também se a motivação do ato administrativo é justa ou injusta, recebendo os embargos.

Interessa notar que o uso da palavra mérito não está relacionado à discricionariedade, mas ao âmago que se debate na ação judicial.

O Ministro Filadelfo Azevedo, por sua vez, destacou que é necessário toda a cautela no exame desses processos, para apurar se, de fato, haveria motivos ou presunções que levariam a acreditar na existência de perseguições, desvios, ou abusos de poder. Somente em tais hipóteses não haveria usurpação de atribuições e as decisões seriam proferidas em caráter disciplinar, em face da prova. De acordo com o Ministro, não seria possível transformar a ação judicial em reprodução do inquérito administrativo para reexame do mérito. Rejeitou os embargos. 
Do voto do Ministro Goulart de Oliveira, que acompanhou o voto do Ministro Orozimbo Nonato, recebendo os embargos, cabe ressaltar sua manifestação acerca da penalidade aplicada ao funcionário: "na hipótese dos autos, os fatos atribuídos ao funcionário não determinariam, nem pela própria lei, a sua exclusão. Punições talvez devessem ser autorizadas mas, de qualquer modo não era o caso de demissão".

Foram rejeitados os embargos pelo voto da maioria.

Em comentário ao acórdão, Vitor Nunes Leal sublinha que o ato de demissão de funcionário público é, antes do mais, um ato administrativo e, se esse funcionário tem estabilidade, esse ato não é discricionário. É necessário que o funcionário incida em determinadas faltas que acarretem a demissão. Dessa forma, a sentença judicial ou o inquérito administrativo de que resultem a demissão são instrumentos adequados para a apuração dos fatos que caracterizam as referidas faltas.

Vitor Nunes Leal acrescenta um argumento importante acerca da posição do Judiciário frente aos demais poderes, afirmando:

\begin{abstract}
"O nosso regime republicano, seguindo o exemplo dos Estados Unidos, procurou realizar a colaboração recíproca dos diversos poderes por meios vários. Um deles consistiu em atribuir ao Judiciário, na sua qualidade de guardião supremo das leis e da Constituição, verdadeira supremacia sobre os dois outros poderes. Essa supremacia, teoricamente, não pertence ao Judiciário, ms ao povo, cuja vontade se presume incorporada na Constituição, de tipo rígida, e nas leis feitas dentro dos limites constitucionais. O Judiciário interpreta e aplica a Constituição e as leis, fazendo prevalecer teoricamente, a vontade do povo. É sabido, porém, que, na prática, essa faculdade técnica de interpretar redunda na supremacia do Judiciário, pois a ele compete, de modo final e conclusivo, dizer do conteúdo das fórmulas legais e constitucionais". ${ }^{195}$
\end{abstract}

Por meio do acórdão analisado, segundo consta do voto do Ministro José Linhares e dos comentários de Vitor Nunes Leal, houve um rompimento de orientação do Supremo, que era no sentido de limitar a indagação judicial às questões de competência e aos aspectos formais do inquérito, para a admissão do entendimento de que cabe ao Judiciário reexaminar

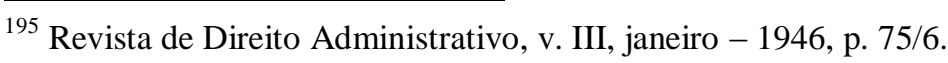


as provas do inquérito, que contemplarão os motivos a serem considerados na demissão, para, inclusive contrapor-lhe novas provas produzidas em juízo. ${ }^{196}$

6.2.2. Recurso em Mandado de Segurança nº 7.320 - Rio Grande do Sul - 21/06/1960 Tribunal Pleno

A inclusão desse acórdão justifica-se pela argumentação do Ministro Lafayette Andrada, Relator, no sentido de que a discrição administrativa consistiria na possibilidade de se praticarem atos baseados em considerações não inteiramente suscetíveis de prova. Tal ponderação conduz ao entendimento de que os motivos do ato seriam insuscetíveis de exame pelo Judiciário .

Nadyr Cipriani Dias Porto, professora estadual, integrante do quadro da Superintendência do Ensino Secundário, lotada no Colégio Estadual Julio de Castilhos, professora de história que já contava com nove anos de magistério, foi removida ex-ofício por ordem do Secretário da Educação.

Em 1/09/1958 foi instaurado processo administrativo contra a impetrante, que foi absolvida pelo Governador do Estado, nos termos do parecer da Comissão de Inquérito. Ao tentar reassumir suas funções no Colégio Julio de Castilhos foi cientificada de que estava impedida de receber o "horário de aula". Alega a impetrante que não pode ser privada de seu cargo senão em virtude de lei, nos termos da Constituição Federal, art. 141, par. $2^{\circ}$ e que o ato do Sr. Secretário da Educação é ilegal e abusivo.

Nas informações prestadas pela Secretaria de Educação afirmou-se que "nada obstante absolvida, as circunstâncias que cercaram aquele processo criaram situação que, sob o ponto de vista pedagógico, tornaram-lhe dificil exercer com eficiência o magistério no referido colégio. Diante dissos, deliberou remover a impetrante para outro estabelecimento de ensino da Capital.."

Em seu voto, o Ministro relator, Lafayette de Andrada, afirmou que o Poder Executivo, por força de uma atribuição do poder discricionário, teria a faculdade de remover "ex-officio" o professor "quando o exigir o interesse do ensino". "Essa faculdade

\footnotetext{
${ }^{196}$ Ibidem, p. 70/1.
} 
discricionária, segundo o Ministro, "deverá ser aplicada com critério de oportunidade e de eficiência, no interesse coletivo.

Sublinhou o Relator que a Administração, via de regra, não motiva seus atos, mas, nem por isso, os atos administrativos ficariam isentos de controle jurisdicional. Para ele, os aspectos dos atos administrativos que são, comumente, subtraídos ao exame judicial são aqueles que dizem respeito aos pressupostos de fato previstos pela lei. Insiste o Ministro em afirmar que a discrição administrativa consiste na possibilidade de se praticarem atos baseados em considerações não inteiramente suscetíveis de provas. Assim, os motivos do ato, em tal caso, são referidos à discrição dos trabalhadores públicos, não cabendo o seu exame, nesta parte, ao poder incumbido de aplicação do direito". (referência à Rev. de Dir. Adm. Vol. 17, pág. 18).

Finaliza o voto ponderando que inexistiu violação, já que a impetrante podia sim ser removida em razão de não ser efetiva.

O Tribunal, por unanimidade, seguiu o voto do Relator, indeferindo a Segurança.

6.2.3 Recurso Ordinário em Mandado de Segurança n ${ }^{\circ}$. 16.807 - Pernambuco - 6/3/1968 - 2a . Turma

Destaca-se, neste acórdão, o entendimento de que somente poderia o Judiciário controlar os motivos do ato, se a própria lei exigisse a comprovação do motivo.

Ementa: O controle judicial só se exerce sobre o ato administrativo motivado, Caso em que a lei exige o motivo mas não a sua comprovação. Apreciação da idoneidade de candidatos a Juiz. Ato discricionário. Livre apreciação exclui a motivação das razões do ato. Denegação do pedido.

O impetrante requereu mandado de segurança ao Tribunal de Justiça de Pernambuco, vez que teve a sua inscrição para o concurso de Juiz de Direito indeferida, sem motivo justificado, pela terceira vez.

O Tribunal negou, por unanimidade, o mandamus, considerando o ato insuscetível de controle jurisdicional. 
Recorreu o impetrante, insistindo contra o arbítrio do Tribunal, argumentado que este deveria justificar o seu ato.

O Ministro Relator, Themístocles Cavalcanti, asseverou que "quando a lei atribui a uma autoridade um poder discricionário sem exigir a comprovação do motivo do seu ato, não existe o controle jurisdicional sobre esse ato, a não ser sob o aspecto de sua legalidade". Para o Ministro, somente seria possível examinar os motivos do ato administrativo, se a lei exigisse a comprovação do motivo.

Themístocles Cavalcanti chega a ponderar que, no caso sob análise, o motivo é exigido, mas a comprovação não; sendo suficiente que a autoridade declare em que texto de lei fundou seu ato.

Destaca, assim, que a Lei Orgânica do Estado de Pernambuco, daria ao Tribunal a competência para recusar a inscrição de candidato cuja idoneidade moral não esteja comprovada ou seja contestada.

Sublinha o Ministro que "o motivo é este que não precisa ser comprovado, mesmo porque seria oportunidade para uma controvérsia em torno do assunto". Finaliza, afirmando: “A idoneidade é de livre apreciação do juiz da inscrição, não exige a lei a sua comprovação, é assim, ato discricionário insuscetível de controle jurisdicional. Nego provimento."

Esse entendimento está hoje superado. O motivo e a motivação devem estar explícitados, permitindo um efetivo controle, incluindo o judicial.

\subsubsection{Embargos no Recurso extraordinário nº 75.421 - Bahia - 18/9/1975 - Tribunal Pleno}

A inclusão deste julgado justifica-se pela discordância entre os Ministros em distinguir se a apreciação da prova do crime envolve exame da legalidade ou se configura em invasão do mérito.

Trata-se de caso em que um funcionário da Prefeitura de Salvador, com mais de trinta anos de serviço, fora demitido mediante inquérito administrativo a bem do serviço público, sob a acusação de haver cometido o crime de corrupção passiva. Ajuizou, então, ação ordinária visando a sua reintegração com todos os direitos e vantagens inerentes ao cargo que 
exercia. Em primeira instância a ação foi julgada improcedente, por entender o Juiz que o ato de demissão estava formalmente perfeito e foi decorrente de inquérito regular, não podendo sofrer exame do judiciário sob o aspecto de ser justo ou injusto, que é restrito à discrição do Poder a que o servidor está subordinado. Em grau de apelação a sentença foi reformada.Os embargos de nulidade e infringentes foram rejeitados por maioria. A Prefeitura interpôs, então, recurso extraordinário, que foi provido; tendo então o funcionário oposto embargos de divergência..

O parecer da Procuradoria Geral da República foi dado no sentido de que a decisão recorrida adentrou no exame do mérito do ato de demissão, em contrariedade aos preceitos constitucionais que limitam o controle judicial dos atos administrativos.

Destaque-se pequeno trecho do parecer:

"Na verdade, o elastecimento desse exame se espelha nos assertivos do v. acórdão, que levaram à conclusão de que o demitido não cometera corrupção passiva, ao contrário do que se entendera no processo administrativo regularmente instaurado. Assim se caracterizou total controle do merecimento do ato, prejudicial à jurisdição criminal, a quem cabia decidir a conotação delituosa, e à própria competência administrativa, anulada na sua atribuição de juiz dos resíduos administrativos vinculados ao inquinado comportamento criminoso do funcionário demitido".

Em seu voto, o Ministro Xavier de Albuquerque discorre longamente, dentre outros aspectos, sobre legalidade e mérito do ato administrativo e afirma que a análise dos motivos faz parte do exame da legalidade, não de mérito.

Coloca a questão de forma bastante clara no seguinte trecho:

Não houve, aqui, decisão no juízo penal. Outra é, portanto, a questão. É a de saber se, punido o funcionário em processo administrativo, ao Poder Judiciário cabe apreciar provas para concluir que a punição não se legitima, em face delas. E a isto pretende a recorrente opor que ao Poder Judiciário é vedado examinar o 'mérito' do ato administrativo.

Pondera, ainda, que considera como de absoluta legitimidade o exame, pelo Poder Judiciário, da prova dos fatos imputados ao funcionário, com a conclusão de que a punição disciplinar, em face dessa prova, é legal, ou não. O exame da legalidade não se confunde com a apreciação das meras formalidades do processo administrativo. E no ato demissório, segundo o Ministro, não há "mérito" excluído da apreciação judicial. 
Segundo Xavier de Albuquerque, verificar se houve ou não o fato que constitui pressuposto da punição não é verificar se ela foi justa ou injusta, mas, sim, se ela foi legal ou não, vez que a lei exige a existência do fato para a aplicação da sanção.

Os embargos foram conhecidos e recebidos por unanimidade.

\subsubsection{Mandado de Segurança n ${ }^{\circ}$. 20.999-2 - Distrito Federal - 21/3/1990 - Tribunal Pleno}

A escolha deste julgado justifica-se pelas colocações precisas do Ministro Celso de Mello acerca do exercício do controle pelo Poder Judiciário, especialmente o contido na ementa, que pondera que

É preciso evoluir, cada vez mais, no sentido da completa justiciabilidade da atividade estatal e fortalecer o postulado da inafastabilidade de toda e qualquer fiscalização judicial. A progressiva redução e eliminação dos círculos de imunidade do poder há de gerar, como expressivo efeito consequencial, a interdição de seu exercício abusivo.

Cuida-se de mandado de segurança que foi impetrado contra ato do Presidente da República, que demitiu o impetrante, a bem do serviço público, do cargo de Agente da Polícia Federal, "por entregar-se à prática de vícios ou atos atentatórios aos bons costumes". A pena de demissão foi imposta após instauração de processo disciplinar, que concluiu por sua inteira e pessoal responsabilidade.

O impetrante alegou ofensa ao princípio da ampla defesa, já que foram indeferidas provas fundamentais à sua defesa, tais como a realização de exame toxicológico e de exame psiquiátrico. Alega, ainda, nulidade absoluta do processo disciplinar por inobservância do contraditório, em razão de não intimação de seu defensor.

Em razão da preliminar levantada, relativa ao não cabimento de mandado de segurança para o questionamento de ato de natureza disciplinar, o Ministro Celso de Mello, Relator, reconhece, primeiramente, a possibilidade de controle jurisdicional das punições disciplinares impostas pela Administração Pública e, quanto a utilização do mandado de segurança, afirmou que

a impugnação judicial de ato disciplinar, mediante utilização do remédio constitucional do mandado de segurança, legitima-se em face de três 
situações possíveis, decorrentes da: (1) incompetência da autoridade, (2) inobservância das formalidades essenciais e (3) ilegalidade da sanção disciplinar.

Acerca do controle punitivo dos atos disciplinares, sublinha o Ministro que os Juízes e Tribunais "só não podem examinar a conveniência, a utilidade, a oportunidade e a necessidade da punição disciplinar (RTJ 100/1381)"; o que, porém, não siginifica a impossibilidade de o Judiciário verificar se existe, ou não, causa legítima que autorize a imposição de sanção disciplinar. Para ele, com essa ressalva, a sindicabilidade judicial sobre os atos disciplinares é ampla.

No caso concreto, Celso de Mello denegou a Segurança, por entender não ter vislumbrado ilegalidade que pudesse justificar a invalidação do ato demissório, segundo ele, "praticado por autoridade competente, nos estritos termos da lei, com observância das formalidades essenciais", no que foi acompanhado pelos demais Ministros.

\subsubsection{Recurso Extraordinário nº 131.661 - Espírito Santo - 26/9/1995 - 2a . Turma}

A escolha deste Julgado jultifica-se pela real importância que foi dado à motivação dos atos administrativos discricionários, diferentemente dos julgados anteriormente analisados.

Cuida-se de recurso extraordinário interposto pelo Estado contra acórdão do Tribunal de Justiça do Espírito Santo, sob o argumento de que o Colegiado havia extravasado o exame do ato administrativo da remoção da servidora pública, adentrando na análise do juízo da conveniência e da oportunidade administrativas.

O Ministro Relator, Marco Aurélio, em seu voto ${ }^{197}$, ressalvou a necessidade da motivação do ato administrativo:

\footnotetext{
"Embora atendidos os pressupostos gerais de recorribilidade, este extraordinário não está a merecer conhecimento. É que, considerados os parâmetros do acórdão impugnado, impossível é tê-lo como enquadrado no permissivo constitucional. Conforme ressaltado pela Procuradoria Geral da República, isto a partir da lição de Celso Antônio Bandeira de Mello, mesmo nos atos discricionários não há margem para que a administração atue com excessos ou desvios ao decidir. É que,em tais hipóteses, coloca-se em plano secundário o interesse público que inspirou a norma. $\mathrm{O}$ acórdão que ora se
}

${ }^{197}$ Pág. 4. 
pretende fulminado nesta via excepcional consigna que a Recorrida, após haver ingressado no serviço público em primeiro lugar e passados dez anos no exercício de certo cargo, não poderia ser removida para Município diverso daquele para o qual especificamente prestou concurso e no qual foi lotada, mormente quando a determinação restou lançada ao mundo jurídico sem que fosse precedida da indispensável motivação. Não conheço do recurso." (grifo não existente no original)

Por unanimidade a Turma não conheceu do recurso.

É bastante nítida a mudança de entendimento verificada neste julgado no que tange à necessidade de motivação, em relação ao MS 16.807, no qual a discricionariedade excluía a motivação e ao MS 20.021, no qual a motivação só seria necessária se houvesse previsão expressa em lei.

6.2.7. Recurso Ordinário em Mandado de Segurança nº 24.699-9 - Distrito Federal $30 / 11 / 2004-1^{\text {a }}$. Turma

Este Julgado foi inserido na pesquisa, em função da abordagem feita pelo Ministro Eros Grau, acerca dos conceitos indeterminados, ao afirmar que a discricionariedade não é consequência da utilização dos conceitos jurídicos indeterminados e que "comete erro quem confunde discricionariedade e interpretação do direito".

Cuida-se de mandado de segurança impetrado contra o Advogado-Geral da União e o Ministro de Estado dos Transportes, apontando como ato coator a Portaria n ${ }^{\circ}$. 1, de 26/2/2002, por meio da qual o recorrente foi demitido do cargo de Engenheiro do Quadro de pessoal do DNER, por improbidade administrativa e por ter-se valido do cargo para lograr proveito pessoal de outrem, em detrimento da dignidade da função pública, com fulcro no art. 117, IX, da Lei 8.112/90 e no art. 11, caput, e inciso I, da Lei 8.429/92. O procedimento disciplinar foi instaurado em face do recorrente, vez que ele, na qualidade de engenheiro do DNER, elaborara os cálculos de atualização de dívida objeto de acordo que seria celebrado entre o DNER e a Viriato Cardoso Construções e Projetos Ltda, utilizando-se de índices e métodos supostamente incorretos.

O Superior Tribunal de Justiça, refutara a alegação de que os motivos que ensejaram a demissão eram falsos e inidôneos, sob o fundamento de que "são questões que não podem ser 
apreciadas na via do mandamus, porque demandaria o reexame de todo o material fático colhido no processo disciplinar, bem como ensejaria incursão indevida sobre o mérito do julgamento efetuado na esfera administrativa".

O voto do Ministro Eros Grau inicia com o tema do limite de atuação do judiciário nos casos que envolvem o exercício do poder disciplinar por parte da Admnistração. Segundo o Ministro, é necessário fazer-se um aparte entre o que seria a pura discricionariedade, em cuja seara não caberia ao Judiciário interferir, e o que seria o domínio da legalidade. Segundo o Ministro,

a doutrina moderna tem convergido no entendimento de que é necessária e salutar a ampliação da área de atuação do Judiciário, tanto para coibir arbitrariedades - em regra praticadas sob o escudo da assim chamada discricionariedade -, quanto para conferir-se plena aplicação ao preceito constitucional segundo o qual 'a lei não excluirá da apreciação do Poder Judiciário lesão ou ameaça a direito' (art. $5^{\circ}, \mathrm{XXXV}, \mathrm{CB} / 88$ )".

Acrescenta Eros Grau, em seu voto, que a discricionariedade não é consequência da utilização, nos textos normativos, de “conceitos indeterminados". Para ele, só há efetivamente discricionariedade quando a norma jurídica válida atribuir essa margem de decisão à margem da lei à autoridade administrativa. Em outros termos: "a autoridade administrativa está autorizada a atuar discricionariamente apenas, única e exclusivamente, quando a norma jurídica válida expressamente a ela atribuir essa livre atuação. Insiste o Ministro 'que a discricionariedade administrativa, e não das circunstâncias de serem ambíguos, equívocos ou suscetíveis de receberem especificações diversas os vocábulos usados nos textos normativos, dos quais resultam, por obra da interpretação, as normas jurídicas. Comete erro quem confunde discricionariedade e interpretação do direito".

Ainda segundo o Ministro, “a Administração, ao praticar atos discricionários, formula juízos de oportunidade, escolhe entre indiferentes jurídicos. Aí há decisão à margem da lei, porque à lei é indiferente a escolha que o agente da Administração vier a fazer. Indiferentes à lei, estranhas à legalidade, não há porque o Poder Judiciário controlar essas decisões. Ao contrário, sempre que a Administração formule juízos de legalidade, interpreta/aplica o direito e, pois, seus atos hão de ser objeto de controle judicial. Esse controle, por óbvio, há de ser empreendido à luz dos princípios, em especial, embora não exclusivamente, os afirmados pelo artigo 37 da Constituição". 
Nesse sentido, de acordo com o Ministro, a Corte tem atuado no sentido de que a Administração exerça o poder disciplinar de modo adequado aos preceitos constitucionais. Concluindo a primeira parte do seu voto, como ele próprio diz, deixa "assente que o Poder Judiciário pode e deve, mediante a análise dos motivos do ato administrativo - e sem que isso implique em invasão da esfera privativa de atribuições reservadas à Administração pela Constituição do Brasil - pode e deve, dizia, rever a pena de demissão imposta ao servidor público".

Ao analisar as penalidades aplicadas: em razão do inciso IX do art. 117 da Lei $n^{\circ}$. 8112/90, concluiu que deve ser afastada; primeiro porque houve afronta ao direito de ampla defesa do impetrante e segundo porque o motivo afigurou-se inválido em face das provas coligidas aos autos. Em relação ao caput e inciso I do artigo 11 da Lei $n^{\circ}$. 8.429/92, concluiu no sentido de que, verificada a prática de atos de improbidade no âmbito administrativo, caberia representação ao Ministério Público para ajuizamento da competente ação e não a aplicação de demissão.

O recurso foi então provido para, reformando o acórdão proferido pelo Superior Tribunal de Justiça, cassar o ato mediante o qual foi imposta a penalidade de demissão e a imediata reintegração ao cargo que ocupava.

Um ponto do julgado merece destaque é o uso da expressão "mérito do ato administrativo". A discricionariedade e o chamado mérito do ato administrativo são temas complexos e mal definidos em termos práticos. O Ministro Eros Grau ${ }^{198}$ fez referência ao mérito, sem que estivesse se referindo, salvo melhor juízo, à conveniência e oportunidade, veja-se :

"E isso porque, repito-o, sempre, em cada caso, na interpretação, sobretudo de textos normativos que veiculem 'conceitos indeterminados' (vale dizer, noções), inexiste uma interpretação verdadeira (única correta); a única interpretação correta -- que haveria, então, de ser exata - é objetivamente incognoscível (é, in concreto, incopgnoscível). Ademais, é óbvio, o Poder Judficiário não pdoe substituir-se à Administração, enquanto personificada no Poder Executivo. Logo, o Poder Judiciário verifica se o ato é correto; apenas isso. Nesse sentido, o Poder Judiciário vai à análise do mérito do ato administrativo, inclusive fazendo atuar as pautas da proporcionalidade e da razoabilidade, que não são princípios, mas

\footnotetext{
${ }^{198}$ Pág. 11/12.
} 
sim critérios de aplicação do direito, podnerados no momento das normas de decisão." (destaque não existente no original).

6.2.8. Agravo no Recurso Extraordinário n ${ }^{\circ}$. 505.439-0 - Maranhão - 12/8/2008 - 2 a Turma

Cuida-se de recurso da União em face da decisão do TRF da $1^{a}$ Região que deu provimento à apelação dos servidores, para declarar nulos atos de disponibilidade de servidores públicos do INSS, do Estado do Maranhão.

O Instituto Nacional do Seguro Social sustentou que que o acórdão hostilizado, a pretexto de analisar a conformação entre o motivo do ato e a sua finalidade, ingressou indevidamente na análise do mérito do ato administrativo, substituindo o juízo discricionário do Poder Executivo por um juízo próprio do Poder Judiciário, o que afrontou o princípio da separação dos poderes.

A União, no mesmo sentido, afirmou que, "como o acórdão não analisou a situação específica dos cargos dos autores em relação ao órgão em que trabalhavam, o Poder Judiciário adentrou o mérito administrativo, substituindo o critério valorativo da autoridade administrativa para modificar a providência por esta tomada em vista de sua conveniência e oportunidade, violando, como visto, os arts. 84 , XXV, e 41, pár. $3^{\circ}$., ambos da CR/88”.

O Ministro Relator, Eros Grau, citou o RE n. 365.368-AgR, DJ de 22.5.07, cuja parte da ementa transcreve-se abaixo, julgado este que fixou entendimento de que, embora não caiba ao Poder Judiciário apreciar o mérito dos atos administrativos, o exame de sua discricionariedade é possível para a verificação de sua regularidade em relação às causas, aos motivos e à finalidade.

"EMENTA: AGRAVO INTERNO. AÇÃO DIRETA DE INCONSTITUCIONALIDADE. ATO NORMATIVO MUNICIPAL, PRINCÍPIO DA PROPORCIONALIDADE. OFENSA, INCOMPATIBILIDADE ENTRE O NÚMERO DE SERVIDORES EFETIVOS E EM CARGOS EM COMISSÃO.

I - Cabe ao Poder Judiciário verificar a regularidade dos atos normativos e de administração do Poder Público em relação às causas, aos motivos e à finalidade que os ensejam. 
A Turma, por votação unânime, negou seguimento ao agravo, já que seria necessário o reexame da matéria fático-probatória, vedado pela súmula n. 279 do Supremo Tribunal Federal.

6.2.9. Ag. Reg. No Recurso Extraordinário no 582.409 - Alagoas - 28/02/2012 - 2a . Turma

Cuida-se de recurso em que servidor militar que teria evitado o suícidio de uma pessoa que pretendia se jogar de uma ponte, tendo inclusive se jogado sobre ela colocando a própria vida em risco, ao requerer administrativamente a promoção por ato de bravura, nos termos do Decreto Estadual nº $4.449 / 80$, e de o Conselho Especial ter acolhido seu pleito, o Comandante-Geral da PM-AL discordou da decisão e não encaminhou o pedido de promoção ao Governador do Estado.

O Tribunal de origem, ao interpretar a legislação estadual aplicável, entendeu que o militar preenchia os requisitos previstos, fazendo jus à promoção por ato de bravura.

No recurso extraordinário sustenta-se violação ao princípio da separação de poderes, sob o argumento de que seria vedado ao Poder Judiciário, no controle jurisdicional, apreciar o mérito dos atos administrativos.

O Ministro Relator, Gilmar Mendes, em seu voto, afirmou que não verificara a ocorrência de violação ao princípio da separação de poderes, já que vislumbrara a ocorrência de ilegalidade, o que tornaria legítimo o controle jurisdicional dos atos administrativos, ainda que discricionários.

Segundo o Ministro, para concluir de forma diversa seria imprescindível a análise da legislação e revisão dos fatos e provas, o que é vedado no âmbito do recurso extraordinário. Foi, então, negado provimento ao agravo regimental.

Neste julgado o Ministro limitou-se a informar que vislumbrara a ocorrência de ilegalidade, o que permitiria o controle jurisdicional. A solução para adentrar-se no mérito do ato administrativo continua a ser a "alegada" ocorrência de ilegalidade. 
6.2.10. Recurso Extraordinário $n^{\circ}$. 372.186 - Rio de Janeiro - 23/4/2013 - $1^{\text {a }}$. Turma

Cuida-se de caso em que dez cabos da Aeronáutica ingressaram em juízo com ação cautelar inominada, visando a suspensão da eficácia da decisão que lhes indeferiu o pedido de prorrogação do tempo de serviço militar, para fins de estabilidade no serviço ativo da Força Aérea Brasileira - FAB. O Juiz Federal julgou procedente a ação, ao entendimento de que a Autoridade Militar não poderia interromper-lhes a carreira, que estava quase a alcançar a estabilidade, sem a devida motivação. Após a interposição de embargos declaratórios e de agravo regimental, ao final rejeitados, forma manejados recursos especial e extraordinário. $\mathrm{O}$ Superior Tribunal de Justiça, por entender que tratava-se de ato discricionário, negou provimento ao apelo.

O interesse nesse julgado, menos pelo resultado em si, tem a ver com os votos dos Ministros Ayres Britto e Teori Zavascki, que tiveram posições divergentes no que tange à motivação do ato discricionário, neste caso específico.

O Ministro Relator, Ayres Britto, inicia seu voto afirmando que:

"Os recorrentes se encontravam às vésperas de completar 10 (dez) anos de serviço ativo momento em que passariam a ter a estabilidade militar - quando foram afastados da corporação por ato administrativo sem a devida fundamentação" (sem grifo no original). Para ele, somente essa conduta administrativa, ou seja, a de não motivar os seus atos, já levaria ao provimento do extraordinário. De acordo com o Ministro, “a Administração Pública, ainda que militar, e mesmo quando se tratar de afastamento de servidor castrense temporário, deve motivar seus atos sob pena de nulidade".

Por sua vez, o Ministro Teori Zavascki, citando diversos precedentes, afirma que: “o militar temporário está sujeito a licenciamento de ofício pela Administração a qualquer tempo, por conveniência e oportunidade. Acrescenta-se que os recorrentes permaneceram por quase 10 anos no serviço público em caráter precário, e não atingiram a estabilidade prevista no art. 50, IV, da Lei 6.880/8. Assim, o ato administrativo impugnado está de acordo com a jurisprudência do Supremo Tribunal Federal”.

Os demais Ministros acompanharam o voto da Ministra Rosa Weber que, em consulta ao sistema processual verificou que a ação principal havia transitado em julgado em 29.9.2011, após negativa de seguimento do Agravo. Assim, segundo a Ministra, o julgamento 
do recurso interposto na ação principal torna prejudicado o recurso extraordinário na ação cautelar. Julgou, então, prejudicado o /recurso extraordinário.

\subsection{Concessão de licença e permissão}

\subsubsection{Recurso Extraordinário no .17126 - Minas Gerais - 31/8/1951 - 2ª . Turma}

A Corte, em 1951, julgou o recurso extraordinário 17126 - MG, que envolvia questão relativa à negativa do Poder Público ao direito de explorar serviços de alto-falantes. $\mathrm{O}$ acórdão analisado teve como relator o ministro Hahnemann Guimarães, como recorrente a Prefeitura Municipal de Cataguazes e recorrida a Rádio Cataguazes S.A.

A recorrente, Rádio Cataguazes S.A., teve concedido pela Primeira Câmara Civil do Tribunal de Justiça, em 30/06/1949, mandado de segurança, com o entendimento de que não havia fundamento legal para o ato do Prefeito de Cataguazes, que negara o direito da impetrante em explorar os serviços de alto-falante.

Tanto o TJMG, quanto o STF manifestaram-se no sentido da possibilidade do judiciário apreciar não só a legitimidade, mas também os fatos reais que serviram de base para o ato discricionário. Assim, no acórdão impugnado afirmou-se que o Poder Judiciário pode apreciar a realidade e a legitimidade dos motivos em que se inspira o ato discricionário da administração. Verificou-se que faltava realidade à razão alegada pelo Prefeito. De acordo com o acórdão, a decisão impugnada não estava contrária à jurisprudência, a qual não exclui da censura judiciária o 'ius politiae'. Se desse exercício resulta lesão a direito individual, o Poder Judiciário deve saná-la (Const. Art. 141, 4º . Apurou-se que o ato do Prefeito lesara o direito certo e evidente da recorrida em explorar os serviços de alto-falantes.

Constou da ementa:

Cabe ao Poder Judiciário apreciar a realidade e a legitimidade dos motivos em que se inspira o ato discricionário da administração. O exercício do poder de polícia está sujeito à censura judiciária. 
6.3.2. Mandado de segurança $n^{\circ}$. 20.012 - Distrito Federal - 11/12/1974 - Tribunal Pleno

O Ministro das Comunicações cassou a permissão dada à Rádio Sociedade Marconi Ltda., para a exploração de serviços de radiodifusão na Capital de São Paulo, alegando infrações da lei no. 4.117/62 c/c com Decreto-lei 236/67. A cassação foi baseada em investigação procedida pelo Departamento Nacional de Telecomunicações (DENTEL).

A Emissora recorreu ao Presidente da República, que indeferiu o recurso:

"Recurso interposto pela Rádio Sociedade Marconi Ltda. contra ato que lhe cassou a permissão para explorar serviços de radiodifusão sonora, na Capital do Estado de São Paulo. Nego provimento ao recurso".

A Rádio impetra então, Mandado de Segurança, com o objetivo de invalidar o despacho presidencial, sob a alegação de nulidade por falta de motivação.

Nas informações prestadas pelo Ministro das Comunicações, ao sustentar a validade da cassação, argumenta com uma citação de José Cretella Junior: "A falta de motivação, no caso presente não invalida o ato, porque, conforme doutrina e jurisprudência dominantes, somente há necessidade de fundamentação e motivação de despachos administrativos quando tal obrigatoriedade é prescrita na lei. (José Cretella Junior in Direito Administrativo do Brasil, ed. 1961, f. 202)".

O Ministro das Comunicações cita também Rafael Bielsa, "mas, mesmo quando o ato deva assumir forma escrita, só nos casos em que a obrigatoriedade da motivação está prescrita em lei, é que a expressão de motivos será necessária sob pena de invalidade do ato, por omissão de motivos. Rafael Bielsa, Derecho Administrativo, volume II, ed. 1964, p. 90”.

O Ministro Relator, Aliomar Baleeiro, destacou que a impetração foi primorosamente elaborada pelo Professor Hely Lopes Meireles, que concentrou suas armas no laconismo do despacho presidencial, pugnando pela nulidade por ausência de motivação.

Pela Procuradoria-Geral opôs-se J. C. Moreira Alves do qual se destaca o seguinte trecho, no sentido da validade da motivação quando contida em parecer ou expediente que lhe deu suporte: 
"Por outro lado, é também de manifesta improcedência a alegada falta de motivação do despacho do Exmo. Sr. Presidente da República, o qual indeferiu o recurso da impetrante".

É pacífico em direito administrativo que não há falta de motivação - mesmo se esta, ao contrário do que ocorre na hipótese, é expressamente exigida em lei - quando o ato administrativo se refere à motivação contida em parecer ou expediente. "É o que a doutrina denomina motivação não contextual, como ensina FRAGOLA (Gli atti amministrativi, $2^{\mathrm{a}}$ ed. Pág. 33/34, Napoli, 1964): 'La motivazione può essere contestuale o non contestuale, se contenuta in um altro atto a cui si fa referimento"”.

Interessante também a citação feita pelo Procurador-Geral, a Bandeira de Melo e Ranelletti, abaixo transcritas:

Nesse sentido, e a título meramente exemplificativo, manifestam-se, entre outros:

BANDEIRA DE MELO (Princípios Gerais de Direito Administrativo, vol. I, pág. 471/472, Rio de janeiro, 1969:

Na hipótese em que a motivação vem prescrita na lei, e, outras que dimanam da própria natureza do ato, segundo o entendimento da doutrina e da jurisprudência. Então, a sua falta, em princípio, invalida o ato, salvo se, comprovado em juízo, constou no processamento que o precedeu'; e RANELLETTI (Teoria degli atti amministrativi speciali, $7^{\mathrm{a}}$ ed., pág. 101/102, Milano, 1945): Quando, peró, il provvedimento sai stato proceduto da um parere di um organo consultivo e il parere sai motivato, é suficiente, per la motivazione del provvedimento, che questo si referisca per essa al parere.

Finaliza Moreira Alves dizendo que o despacho de indeferimento foi baseado numa exposição motivada, que foi anexada, por cópia, aos autos. Não havendo, pois, a falta de motivação alegada.

Afirmou o Relator que o Supremo Tribunal Federal sempre sustentou a necessidade de motivação do ato administrativo; entretanto, diz ele que a falta de motivação expressa não pode ser considerada um defeito se o motivo eficiente de fato existe e pode ser controlado a posteriori. Para ele, “o importante, pois, é que exista de fato um motivo eficaz e suficiente, ainda que ele não seja manifestado, de começo, no ato. E esse motivo me parece ter ocorrido no caso dos autos". 
Para o Ministro Relator, o que interessa não é proteger o formalismo abstrato, mas apenas repelir a inexistência de motivação, que corresponderia à inexistência real dos fatos motivadores. Conclui, dizendo, "entendo, por isso, que o ato presidencial foi motivado e o motivo existe de fato até prova em contrário, impossível no m.s., não importando a circunstância de não haver referência expressa no breve despacho da alta autoridade. .......Não houve ilegalidade, abuso ou desvio de poder. A medida era cabível em face das irregularidades apuradas e foi tomada por autoridade competente, depois de processo administrativo, ciência e defesa do interessado. No âmbito limitado do m.s., não é possível reexaminar-se a série de imputações da autoridade administrativa."

A decisão final foi pelo indeferimento do mandado, de forma unânime.

\subsubsection{Recurso Extraordinário 111.413 - Rio de Janeiro - 23/2/1988 - 2a . Turma}

Trata-se de mandado de segurança impetrado contra ato do Secretário Municipal da Fazenda que cassou licença para exploração de banca de jornais e revistas. Segundo informações da Secretaria, a cassação se deu em decorrência de irregularidade apurada em face de recurso interposto por Rodolfo Graziano Sinforoso, anterior permissionário da banca. O acórdão em apelação manteve a sentença singular, negando a segurança.

No parecer da Procuradoria-Geral da República, cujas razões foram adotadas integralmente pelo Relator, consta a essência do entendimento acerca do controle sobre essa modalidade de ato discricionário: "Vê-se, por conseguinte, que a autorização concedida à recorrente para exploração de banca de jornais não é constitutiva de direitos, mas, ao revés, caracteriza-se pela mutabilidade e precariedade, sujeita sempre ao juízo de conveniência e oportunidade da Administração Pública, cuja apreciação é vedada ao Poder Judiciário por se situar, exatamente, na faixa de poderes discricionários que lhe é conferida."

A decisão foi, unânime, pelo não conhecimento.

6.4. Ato relacionado à expulsão/extradição de estrangeiro 
6.4.1. Habeas Corpus nº 63.815 - São Paulo - 02/04/1986 - Tribunal Pleno

Cuida-se de expulsão de alienígena por decreto publicado no Diário Oficial de 6/2/1986, cuja efetivação foi sustada por força de liminar. O inquérito foi instaurado acolhendo solicitação do DFJ, fundamentada em auto de prisão em flagrante do paciente por tráfico de entorpecentes.

Conforme consta do voto do Relator, citando informações prestadas, constantes dos autos, o expulsando-paciente era acusado de integrar uma vasta rede internacional de traficantes de drogas, que tinha à frente o italiano Tommaso Buscetta.

O Ministro Relator, Djaci Falcão, afirmou, em seu voto, que a expulsão constitui ato de soberania que visa preservar o interesse nacional, mas que "não fica isento do controle judicial, no que toca a ilegalidade, in genere. Todavia, compete ao Presidente da República deliberar sobre a conveniência e a oportunidade da medida. O juízo de valor quanto à justiça do ato escapa a apreciação do Poder Judiciário.”

O Ministro Djaci Falcão conclui seu voto denegando o pedido, vez que não se configurou coação ilegal.

6.4.2. Habeas corpus n ${ }^{\circ}$. 64.345-1 - Distrito Federal - 17/9/1986 - Tribunal Pleno

Trata-se de caso em que o Presidente da República determinou que o estrangeiro fosse expulso somente após o cumprimento da pena que lhe fora imposta. Juan Casimiro Vega Ponce impetrou HC a fim de ser imediatamente expulso do país, sob a alegação de que fora condenado a 13 anos de reclusão e encontrava-se preso desde 20/11/1982; portanto, se não fosse expulso teria de cumprir cerca de 9 anos de reclusão, sem poder gozar de regime carcerário mais favorável, em face do decreto expulsório.

Nas informações prestadas pelo ilustre Presidente da República, por meio de parecer do Ministério da Justiça, no sentido de que "somene o Juiz das Execuções, à vista dos elementos fáticos, poderia dizer se o alienígena tinha ou não direito à progressão do regime, sendo de buscar a devida prestação jurisdicional, caso lhe fosse negado direito, apenas por ser 
estrangeiro. De outra parte, o Presidente da República não poderia ser compelido a modificar o ato que legalmente praticara, no pleno uso de seu poder discricionário de resolver sobre a conveniência e oportunidade de expulsar o estrangeiro."

No parecer da Procuradoria-Geral da República, cujo "aprovo” foi dado pelo Dr. José Paulo Sepúlveda Pertence, e que serviu de fundamento para o voto do Relator consta menção ao acórdão proferido no julgamento do HC 61.020, da lavra do Ministro Francisco Rezek: “ Expulso o estrangeiro sem prejuízo das penas a que estiver sujeito no País, só o Presidente da República, pode, antes de extintas tais penas, precipitar a efetivação da medida, mandando que se aplique o art. 67 do Estatuto do Estrangeiro. (Plenário, unânime, DJ de 12.8.83, pág. 11760)".

O Relator, Ministro Aldir Passarinho, votou pelo indeferimento do "habeas corpus", no que foi acompanhado pelos demais Ministros, sob o entendimento de que o ato de expulsão se situa no âmbito do poder discricionário do Presidente da República e, somente ele, poderia decidir atendendo aos critérios de conveniência e oportunidade.

\subsubsection{Extradição no . 1.114-6 República do Chile - 12/6/2008 - Tribunal Pleno}

Cuida-se de pedido de extradição requerida pelo governo do Chile, com base em Tratado de Extradição firmado com o Brasil e fundamentado em requerimento da Corte Suprema do Chile e em ordem de prisão do juizado da $16^{\text {a }}$ Vara Criminal de Santiago. O Extraditando está sendo processado no Chile porque teria praticado crime contra a liberdade sexual de menor.

Alegou o extraditando em sua defesa, além de outros, que, para a concessão da extradição faz-se necessária a manifestação expressa do Presidente da República, o que não teria ocorrido.

Sobre essa questão a Ministra trouxe manifestação do Ministro Celso de Mello no julgamento da Questão de Ordem na Extradição n”. 568, de 7.5.1993: “o pedido extradicional, deduzido perante o Estado brasileiro, constitui - quando instaurada a fase judicial de seu procedimento - ação de índole especial, de caráter constitutivo, que objetiva a formação do 
título jurídico apto a legitimar o Poder Executivo da União a efetivar, com fundamento em trtado internacional ou em compromisso de reciprocidade, a entrega do súdito reclamado".

Segundo a Ministra, o Supremo Tribunal Federal limita-se a analisar a legalidade e a procedência do pedido de extradição, com base no Regimento Interno do STF, art. 207; Constituição da República, art. 102, Inc. I, alínea g; e Lei nº . 6.815/80, art. 83.

Conclui a Ministra que, se indeferido o pedido, não se constitui o título jurídico, e, sem este, o Presidente da República não pode determinar a extradição. Se, deferido o pedido de extradição, "a efetiva entrega do súdito ao Estado requerente fica a critério discricionário do Presidente da República".

O Tribunal, por unanimidade e nos termos do voto da relatora, deferiu o pedido de extradição.

\subsection{Desapropriação}

6.5.1. Mandado de segurança ${ }^{\circ}$. 20.861 - Distrito Federal - 7/2/1990 - Tribunal Pleno

Desapropriação para reforma agrária - Mandado de segurança contra Decreto presidencial de expropriação. Medida cautelar deferida antes, por juiz de $1^{\circ}$ grau contra o INCRA, para suspensão do procedimento administrativo que desrespeitando tal decisão judicial, nele prosseguiu, ensejando, ao final, o decreto expropriatório. Mandado de segurança deferido, por maioria, para anulação do decreto.

Cuida-se de mandado de segurança contra ato do Presidente da República que declarou de interesse social, para fins de desapropriação, o imóvel rural situado no município de Itacaré, na Bahia e compreendido em zona classificada como prioritária para fins de reforma agrária. O imóvel foi classificado pelo INCRA como latifúndio por exploração. Apesar da liminar concedida em primeira instância, determinando a sustação do procedimento administrativo até conclusão da prova antecipada, conforme requerido pelos impetrantes, houve a edição do decreto expropriatório. Pretendiam os impetrantes provar que o imóvel preenchia os requisitos legais para ser considerado "empresa rural" e, com isso, ser preservado da expropriação. 
Sustenta o INCRA que trata-se sim de latifúndio por exploração e que o mandado de segurança não seria a via adequada para obtenção do enquadramento do imóvel como empresa rural. Alega, também, que "o exame dos motivos em que o poder expropriante assentou sua vontade para decretar e fazer valer o interesse público" escaparia à competência do Poder Judiciário. ${ }^{199}$

O Ministro Aldir Passarinho, Relator, coloca a questão de forma clara "embora a inicial sustente ser o imóvel insuscetível de desapropriação para fins de reforma agrária, não visa o mandado de segurança que se reconheça, na oportunidade, tal fato, mas sim que não poderia ser expedido o Decreto $n^{\circ}$. 96.258/88 em face da liminar que fora concedida na ação cautelar inominada".

O trecho do voto do Ministro Aldir Passarinho a seguir transcrito, é o que justifica a inclusão deste julgado na pesquisa, quando inclui no princípio da legalidade a obediência às decisões judiciais:

"As atividades administrativas se encontram sujeitas ao controle jurisdicional, e se exerce quando o Poder Judiciário é chamado a resolver situações contenciosas entre a Administração Pública e o indivíduo, como observa Seabra Fagundes em sua obra clássica 'O Controle dos Atos Administrativos pelo Poder Judiciário" (4ª ed., pág. 111); e tal controle se exerce na apreciação da legalidade dos atos administrativos, e o cidadão pode provocar o controle jurisdicional contra a Administração, não só ajuizando ação para obter ressarcimentos de prejuízos que lhe foram causados pela Administração, mas procurando sustar atos desta que lhe sejam lesivos. E o mandado de segurança é via processual adquada para suscitar o controle juriscicioanal sobre ato de qualquer autoridade que, por sua ilegalidade ou abuso de poder, viole ou ameace direito individual líquido e certo (Constituição Federal, art. 153, par. 23 da E.C. no $1 / 69$ e art. $5^{\circ}$ LXIX da nova Carta Política). E os impetrantes delas se utilizaram adequadamente para exercer o controle do Poder Judiciário sobre o ato que consideram lesivo ao seu direito, observando-se que a força coativa decorre da própria obrigação de a Administração submeter-se à ordem jurídica, com base no chamado princípio da legalidade, incluindo-se nesse princípio a obediência

${ }^{199}$ Pág. 7/8. 
às decisões judiciais, exercendo-se o controle jurisdicional "por uma intervenção do Poder Judiciário mo processo de realização do direito" ${ }^{200}$.

O Tribunal, por maioria, vencido o Ministro Paulo Brossard, concedeu a Segurança.

\subsection{Revogação de processo licitatório}

6.6.1. AG.REg. no Agravo de Instrumento 228.554-4 - Minas Gerais - 25/10/2005 - $1^{\mathrm{a}}$. Turma

Cuida-se de agravo de instrumento que, na origem, indeferiu processamento de recurso extraordinário contra acórdão que deu provimento à apelação, para julgar improcedente ação anulatória de processo de licitação (para locação de veículos com motorista), por entender que, antes da homologação da licitação não se concretiza direito adquirido, nem ato jurídico perfeito.

O Ministro relator, Cezar Peluso, adotando os fundamentos do subprocurador, manifesta-se no sentido que não é o caso de revogação do processo licitatório até então válido, sem repercussão alguma na esfera jurídica dos concorrentes originais.

Explica, que não é o caso de anulação (que suporia vício de validez), mas de mera revogação do processo licitatório até então válido, antes da homologação, sem repercussão alguma na esfera jurídica dos concorrentes.

Citando Miguel Reale, sublinhou que

a revogação é uma expressão da discricionariedade no processamento positivo das funções da Administração; seu fundamento último, como o de todo ato administrativo, é o interesse público; seu fundamento imediato é a liberdade, ou melhor, a discrição administrativa, por não estar a decisão vinculada a um dos elementos de fim e de mediação" (Miguel Reale, Revogação e Anulamento do Ato Administrativo, RJ, Forense, $1^{\mathrm{a}}$. ed., 1968, p.44, $\left.\mathrm{n}^{\mathrm{o}} .10\right)$.

A Turma negou seguimento ao recurso, por unanimidade.

${ }^{200}$ Pág. 7/8. 
6.6.2. Recurso Ord. Em Mandado de Segurança nº. 24.188-1 - Distrito Federal - 14/8/2007$2^{\mathrm{a} .}$ Turma

Cuida-se de recurso ordinário de decisão do Superior Tribunal de Justiça que denegou mandado de segurança contra ato do Ministro de Estado das Comunicações, que revogou procedimento licitatório, objeto do Edital de Concorrência no 35/98 - SSR/MC, que tinha por finalidade outorgar concessão para a exploração do serviço de radiodifusão de sons e imagens (televisão) na cidade de Araçatuba, no Estado de São Paulo.

A concorrência foi revogada após a fase de habilitação, antes do início da fase de qualificação das propostas, sob vários fundamentos. Segundo constou, a revogação da licitação, à vista daqueles fundamentos tinha como objetivo preservar o interesse público regional e garantir o desenvolvimento e ampla concorrência no setor. Pareceres técnico e jurídicos ampararam o ato de revogação.

As recorrentes insurgiram-se contra a ausência do contraditório e da ampla defesa, antes da revogação do certame. Ataca também o principal argumento do acórdão recorrido, que diz que "revogação de licitação em andamento com base em interesse público devidamente justificado não exige o cumprimento do par. $3^{\circ}$. do art. 49 da Lei 8.666/93.

O Ministro Cezar Peluso, em seu voto, fez referência à diferença entre revogação por interesse público e anulação por vício que a invalide. Segundo o Ministro, se o caso fosse de anulação, não seria desarrazoado reconhecer ao licitante a aplicação do princípio do contraditório e ampla defesa; diferentemente no caso de revogação, já que esta é ato discricionário, pautado por juízo de conveniência e oportunidade da autoridade administrativa.

Para o Ministro, o exercício do poder discricionário está no resguardo de direitos subjetivos nascidos do ato revogado ou por revogar e, antes da homologação da licitação nenhum direito subjetivo exsurge aos concorrentes, capaz de impedir a revogação da abertura de processo licitatório. A Administração revogou a licitação por motivo de mérito, recorrendo a válida ação alternativa mais conveniente, com renúncia à anterior, não menos válida.

A Turma, por unanimidade, negou provimento ao recurso. 
Embora a Administração houvesse fundamentado o ato não houve análise por parte do Judiciário do quanto informado. Simplesmente foram aceitos como bons e suficientes. 


\section{Superior Tribunal de Justiça}

Os julgados analisados demonstram que o controle jurisdicional do ato administrativo discricionário ainda suscita divergência entre os julgadores. Na verdade, o pivô da divergência é o chamado mérito administrativo, que congrega a oportunidade e a conveniência na prática do ato pela Administração.

Os acórdãos provenientes do Superior Tribunal de Justiça foram dispostos em ordem cronológica de data, do mais antigo ao mais recente, independentemente do tema a que se relaciona.

A análise dos julgados procura destacar os aspectos da decisão que interessam à pesquisa e inicia-se com um relato breve dos fatos, com a finalidade de proporcionar um entendimento acerca dos motivos que levaram à pratica do ato e, também, a um melhor entendimento da decisão.

Para se ter ideia da divergência de entendimento acerca do controle do ato administrativo discricionário no que diz respeito ao mérito, a leitura desses dois acórdãos dá bem a magnitude do problema.

O recurso especial $n^{\circ}$. 429.570, de 11/11/2003, relatado pela Ministra Eliana Calmon, objetivava, em sede de ação civil pública, que o Município promovesse obras de recuperação em área degradas por erosões. A Ministra, em seu voto, assentou seu entendimento no sentido de que "não se pode simplesmente dizer que, em matéria de conveniência e oportunidade, não pode o Judiciário examiná-las. Aos poucos, o caráter de liberdade total do administrador vai se apagando da cultura brasileira e, no lugar, coloca-se na análise da motivação do ato administrativo a área de controle. (...) A tendência, portanto, é a de manter fiscalizado o espaço livre de entendimento da Administração, espaço este gerado pela discricionariedade".

Por sua vez, no julgamento do recurso em mandado de segurança $n^{\circ}$. 37.964/CE, de 30/10/2012, impetrado contra ato do Secretário de Segurança Pública e Defesa da Cidadania do Estado do Ceará e do Secretário de Planejamento e Gestão do Estado do Ceará, consubstanciado na exclusão da impetrante de concurso público destinado ao preenchimento de vagas para o cargo de Delegado de Polícia Civil do Estado do Ceará, a Ministra asseverou não caber ao Poder Judiciário, salvo em caso de ilegalidade, 
defeito de forma, abuso de autoridade ou teratologia, adentrar no mérito do ato administrativo revendo o juízo de conveniência e oportunidade da autoridade tida como coatora.

Somente por esse exemplo, já é possível visualizar a dificuldade no que toca ao controle do chamado mérito do ato administrativo.

\subsection{Acórdãos selecionados do Superior Tribunal de Justiça}

\subsubsection{Recurso Especial n ${ }^{\circ}$. 1.225/ES, $1^{\text {a }}$. Turma - Julgamento: 14/3/1990}

Trata-se de recurso especial interposto contra aresto que teria negado vigência a texto legal, especialmente ao Decreto-lei n'. 3.365/41, art. 5․, alínea “m” . Conforme consta do relatório do Ministro Geraldo Sobral, a razão de fundo da ação pode ser assim resumida: a ora recorrente era proprietária de prédio que fora alugado à Loja Maçônica Castelense. Findo o contrato, houve recusa em desocupá-lo, tendo sido ajuizada ação de despejo. No curso do processo, a Prefeitura municipal, cujo Prefeito era membro efetivo daquela Loja, baixou decreto expropriatório, declarando o imóvel de utilidade pública; e que a desapropriação destinava-se à “construção de imóveis". Foi então proposto mandado de segurança contra o ato do Prefeito Municipal.

A ementa desse acórdão é bastante significativa, pois, embora defenda a impossibilidade do Judiciário incursionar no que se convencionou chamar de oportunidade e conveniência, argumenta que o Judiciário pode e deve verificar os elementos que indicam a legitimidade do ato, (neste caso a própria norma que expropria o imóvel, para fins de utilidade pública ou interesse social) ou seja, a própria finalidade, vez que aí reside o freio à discricionariedade. Essa seria a razão pela qual a declaração de utilidade pública tem que indicar, precisamente, o fim a que se destina a expropriação. Não seria o bastante a finalidade indicada na norma expropriatória, “construção de imóveis". Haveria que ser indicado o interesse público perseguido. 
O Ministro Armando Rolemberg, entendeu, por sua vez, que a finalidade declarada estava de acordo com o Decreto-lei 3.365/41 que assim estabelecia, "deve ser precedida de declaração respectiva e poderá se dar quando o bem desapropriado destinar-se à "construção de edifícios públicos", que, segundo o Ministro, é exatamente a finalidade indicada no decreto expropriatório. Este voto foi o único divergente.

O acódão foi assim ementado,

"ADMINISTRATIVO. DESAPROPRIAÇÃO. FINALIDADE
SOCIAL. INOCORRÊNCIA.
I - Conquanto ao Judiciário seja defeso incursionar sobre a
oportunidade e conveniência de desapropriação, pode e deve ele
escandir os elementos que indicam a legitimidade do ato bem como a
vinalidade poir, aí, reside o freio à discricionariedade, por isso que a
declaração de utilidade pública terá de indicar, precisamente, o fim a
que se destina a expropriação.
II - Tedo em conta o interesse público, é vedado à administração
desapropriar 'para construção de imóveis' sem especificar a
perseguição do interesse público, é dizer, a finalidade.
III - Se a finalidade referida no decreto expropriatório é fraudada,
desmerece-se, por si própria, a desapropriação.

O recurso foi provido, por maioria.

7.2.2. Recurso Especial no. 21.923-5 - $1^{\text {a }}$. Turma. Julgamento: 20/5/1992

O Ministro Relator, Humberto Gomes de Barros, baseou o seu voto na existência de violação ao princípio da moralidade administrativa, afirmando que qualquer conduta que viole esse princípio se mostraria ilegal e inconstitucional.

Cuida-se de ação anulatória de ato administrativo, consistente no pedido de anulação do Decreto $\mathrm{n}^{\mathrm{o}}$. 1.657/84, que declarara de utilidade pública, para fins de desapropriação, imóvel pertencente aos autores. O pedido foi julgado improcedente e, em apelação, o Tribunal deu provimento parcial para determinar o quantum da indenização. Os autores intentaram, então, recurso especial. O acórdão recorrido entendeu que não era possível o exame do mérito do ato administrativo e que à análise competia, tão-somente, verificar se as formalidades legais haviam sido observadas. 
Consta do voto que o julgamento da apelação ocorrera antes da Constituição de 1988, momento em que, segundo o Relator, "a imoralidade, desde que camuflada nos ditames legais não era expressamente sancionada, embora já o fosse, implicitamente”. Entretanto, com a moralidade elevada à condição de preceito constitucional, "qualquer conduta que a violente revela-se ilegal e, mesmo inconstitucional”. Para o Ministro, "exigir-se o vício da ilegalidade formal para comprovar a imoralidade é contrariar o espírito da Constituição, que quer, com esse princípio, cobrar da Administração, além de uma conduta legal, um comportamento ético".

Interessante a parte final da decisão, na qual o Ministro conhece do recurso e lhe dá provimento, determinando que os autos retornassem ao Tribunal "a quo" para, nada mais , nada menos, que a apreciação do mérito do ato administrativo, para não haver a supressão de instância. O mérito indicado pelo Ministro poderia, entretanto, referir-se à conveniência e oportunidade do ato administrativo ou, apenas, o "juízo sobre o objeto litigioso". A segunda hipótese é a mais plausível, vez que a conveniência e oportunidade permanecia longe do controle do Judiciário.

A decisão foi assim ementada, frisando que o ato administrativo pode ser examinado pelo Poder Judiciário sob o aspecto da moralidade e do desvio de poder:

\footnotetext{
ADMINISTRATIVO - ATO ADMINISTRATIVO, MORALIDADE, EXAME PELO JUDICIÁRIO - ART. 37 DA $\quad$ CF DESAPROPRIAÇÃO - ART. 20 DO DL 3.365/41.

É lícito ao Poder Judiciário examinar o ato administrativo, sob o aspecto da moralidade e do desvio de poder. Com o princípio inscrito no Art. 37, a Constituição Federal cobra do Administrador, além de uma conduta legal, comportamento ético. $\mathrm{O}$ art. 20 do DL n ${ }^{\circ}$.3.365-41 "qualquer questão relativa à desapropriação.
}

7.2.3. Recurso Especial nº 36.611-9, $1^{\text {a }}$. Turma. Julgamento: 21/6/1994

Com o mesmo entendimento exposto no acórdão anterior, o Ministro Relator, Humberto Gomes de Barros, baseou o seu voto na violação do princípio da moralidade 
administrativa, afirmando que qualquer conduta que violasse esse princípio se mostraria ilegal e inconstitucional.

Cuida-se também de ação expropriatória por utilidade pública movida pelo município de São Francisco do Sul e ação ordinária de nulidade de decreto de desapropriação ajuizada pelos proprietários. Os dois processos foram reunidos por continência. Em primeiro grau, a ação de desapropriação foi declarada procedente e improcedente a demanda anulatória. O Tribunal de Justiça do Estado de Santa Catarina confirmou a sentença, destacando a inexistência de vício de desvio de poder; o que levou os sucumbentes ao manejo do recurso em questão.

Constava do Decreto Municipal 244, de 2/9/86 que ficava declarada de utilidade pública (...) para efeito de desapropriação amigável ou judicial, área de terra e benfeitorias, necessárias para fins de edificação de uma praça pública (......).

O próprio agente administrativo confirmara a inexistência de projetos urbanísticos e estudos técnicos voltados à realização da obra pública no local; reconheceu como objetivo da desapropriação o de impedir o prosseguimento da edificação que estava sendo realizada pelos proprietários; mencionou que haveria a pretensão de futura implantação de ponte, a ser localizada, possivelmente, atrás da área expropriada.

Para o Relator, Ministro Humberto Gomes de Barros, foi considerado manifesto o desvio de poder, já que houve um afastamento entre o que prescrevia o Decreto e a realidade da desapropriação. Segundo ele, o ato expropriatório exprimiu exercício de poder em sentido diverso da finaldade da desapropriação. Desse modo, o decreto que declarou os imóveis de utilidade pública para fins de desapropriação seria inválido, vez que o agente público buscou a consecução de objetivo alheio à natureza do ato expropriatório.

Neste acórdão, o Poder Judiciário analisou o ato da administração, do ponto de vista do desvio de poder e desvio de finalidade, considerando ter havido violação à moralidade administrativa. 
7.2.4. Recurso Especial no ${ }^{\circ}$ 63128/GO, 6a Turma. Julgamento: 20/5/1996

“CONSTITUCIONAL E ADMINISTRATIVO. CONSTITUIÇÃO DIRIGENTE E PROGRAMÁTICA. ESTATUTO DA CRIANÇA E DO ADOLESCENTE. AÇÃO CIVIL PÚBLICA PARA OBRIGAR O GOVERNO GOIANO A CONSTRUIR UM CENTRO DE RECUPERAÇÃO E TRIAGEM. IMPOSSIBILIDADE JURÍDICA. RECURSO ESPECIAL NÃO CONHECIDO.

I - O Ministério Público do Estado de Goiás, com base nas Constituições Federal e Estadual e no art. $4^{\circ}$ do Estatuto da Criança e do Adolescente, ajuizou ação civil pública para compelir o Governo Estadual a construir um centro de recuperação e triagem, em face de prioridade genericamente estabelecida. O TJGO, em apelação, decretou a carência da ação por impossibilidade jurídica.

II - A Constituição Federal e em suas águas a Constituição do Estado de Goiás são 'dirigentes' e 'programáticas'. Têm, no particular, preceitos impositivos para o legislativo (elaborar leis infraconstitucionais de acordo com as 'tarefas' e 'programas' préestabelecidos) e para o judiciário ('atualização constitucional'). Mas, no caso dos autos, as normas invocadas não estabelecem, de modo concreto, a obrigação do Executivo de construir, no momento, o centro. Assim, haveria uma intromissão indébita do Poder Judiciário no Executivo, único em condições de escolher o momento oportuno e conveniente para a execução da obra reclamada.

III - Recurso especial não conhecido. Decisão recorrida mantida."

Neste julgado, destacou-se a ementa do acórdão com o intuito de apenas mostrar a diferença no entendimento da Corte, se comparados aos acórdãos do Recurso Especial $n^{\circ}$. 429.570, da $2^{a}$. Turma, julgado em 11/11/2003, relatado pela Ministra Eliana Calmon e Recurso Especial n $n^{\circ}$. 575.280, da $1^{\text {a }}$. Turma, julgado em 2/9/2004, cuja relatoria ficou a cargo do Ministro Luiz Fux e que são analisados mais à frente.

7.2.5. ROMS 9319/MG, 1ª. Turma. Relator: Garcia Vieira. Julgamento: 9/2/1999. 
Trata-se, na origem, de mandado de segurança impetrado em face de ato da Administração que indeferiu pedido do impetrante de adesão ao Programa de desligamento Voluntário, instituído pela lei nº 12.280, de 1996.

O impetrante havia sido dispensado do serviço público, tendo sido reintegrado no cargo por força de liminar em mandado de segurança, ainda não julgada definitivamente. Considerou o Relator, dessa forma, não haver nenhum direito do autor em participar do referido programa.

O acórdão deixou explicitado não caber ao Poder Judiciário examinar se existe ou não conveniência e oportunidade para o acolhimento do pedido do servidor. $\mathrm{O}$ Ministro asseverou que o Judiciário só poderá examinar se o ato foi baixado com obediência aos princípios da legalidade, impessoalidade, moralidade e da publicidade.

Interessante que o Ministro Garcia Vieira refere-se à análise da conveniência e oportunidade não do ato administrativo, mas sim do pedido do autor, afirmando que o Judiciário "não pode ele substituir o administrador para decidir se é ou não conveniente e oportuno a pretensão do autor".

Conclui, afirmando que ao Judiciário é vedado o exame do mérito do ato administrativo, só podendo examinar a sua legalidade.

A Turma, por unanimidade, negou provimento ao recurso, tendo sido o acórdão assim ementado:

\footnotetext{
"ADMINISTRATIVO - MANDADO DE SEGURANÇA SERVIDORA PÚBLICA FEDERAL - NOMEAÇÃO PARA CARGO EM COMISSÃO - PRETERIÇÃO - INEXISTÊNCIA - OFENSA AOS PRINCÍPIOS DA RAZOABILIDADE E ISONOMIA NÃO DEMONSTRADOS - ATO DISCRICIONÁRIO - ILEGALIDADE INOCORRÊNCIA - DIREITO LÍQUIDO E CERTO INEXISTENTE - SEGURANÇA DENEGADA.
}

1 - Não há que se falar em preterição ou ilegalidade quanto à nomeação para cargo em comissão, tendo em vista que tal designação configura ato administrativo discricionário, submetido exclusivamente à conveniência e oportunidade da autoridade pública competente, de livre nomeação e exoneração, considerada a relação de confiança entre o 
nomeado e o seu superior hierárquico, não podendo o Judiciário adentrar-se no meritum adotado pelo mesmo. Precedente (RMS 15.056/BA).

2 - Ausência de direito líquido e certo a ser amparado.

3 - Segurança denegada. Custas ex lege. Sem honorários advocatícios a teor das Súmulas 512/STF e 105/STJ." (MS 9181/DF, Relator Ministro JORGE SCARTEZZINI, DJ de 08.03.2004). "ADMINISTRATIVO - CONTROLE JUDICIAL DO ATO DISCRICIONÁRIO - EXAME DO MÉRITO DO ATO ADMINISTRATIVO - IMPOSSIBILIDADE. Compete à Administração Estadual o poder discricionário de decidir sobre o deferimento ou não do pedido de adesão ao PDV. Não pode o Poder Judiciário substituir o administrador, decidindo sobre a conveniência e oportunidade do ato discricionário. Recurso improvido."

7.2.6. Mandado de Segurança $n^{\circ} .8780 / \mathrm{DF}, 3^{\mathrm{a}}$. Seção. Relator: Ministro Gilson Dipp. Julgamento: 8/10/2003

Cuida-se de mandado de segurança em que a impetrante insurge-se contra ato do Exmo. Sr. Ministro de Estado da Previdência e Assistência Social, consistente na edição da Portaria $n^{0}$ 850, que culminou na cassação de sua aposentadoria. Alegou, em síntese, violação ao princípio do devido processo legal no transcorrer do processo administrativo disciplinar, consistente em incompetência da autoridade como coatora; inexistência de condenação penal a embasar a possibilidade de aplicação da penalidade; inobservância do prazo de término do processo administrativo disciplinar; e, não teria sido apontado o ato omissivo ou comissivo que ensejou a falta grave.

Atendo-se apenas ao aspecto do acórdão que interessa à presente pesquisa, destaque-se que o Relator asseverou que o controle jurisdicional do processo administrativo deve limitar-se ao campo da regularidade do procedimento e à legalidade do ato demissionário, não sendo possível qualquer incursão no mérito administrativo, com o fito de verificar o grau de conveniência e oportunidade.

Em relação ao controle jurisdicional do processo administrativo, impõe-se esclarecer que a atuação do Poder Judiciário circunscreve-se ao campo da regularidade do procedimento, bem como à legalidade do ato demissionário, sendo-lhe defesa qualquer incursão no mérito 
administrativo a fim de aferir o grau de conveniência e oportunidade.

Assim, mostra-se inviável a análise das provas constantes no processo

administrativo, já que a prova produzida foi clara ao referendar a cassação da aposentadoria da servidora.

A Seção denegou a segurança, por unanimidade, tendo sido o acórdão assim ementado.

\begin{abstract}
ADMINISTRATIVO. SERVIDOR PÚBLICO. CASSAÇÃO DE APOSENTADORIA. PROCESSO ADMINISTRATIVO DISCIPLINAR. INCOMPETÊNCIA DA AUTORIDADE. NULIDADES. OFENSA AO DEVIDO PROCESSO LEGAL. INOCORRÊNCIA. EXCESSO DE PRAZO. INDEPENDÊNCIA DAS ESFERAS ADMINISTRATIVA E PENAL. IMPOSSIBILIDADE DE ANÁLISE PELO PODER JUDICIÁRIO DO MÉRITO ADMINISTRATIVO. "WRIT" IMPETRADO COMO FORMA DE INSATISFAÇÃO COM O CONCLUSIVO DESFECHO DO PROCESSO ADMINISTRATIVO DISCIPLINAR. ORDEM DENEGADA.

$[\ldots]$

III - A sanção administrativa é aplicada para salvaguardar os interesses exclusivamente funcionais da Administração Pública, enquanto a sanção criminal destina-se à proteção da coletividade. Consoante entendimento desta Corte, a independência entre as instâncias penal, civil e administrativa, consagrada na doutrina e na jurisprudência, permite à Administração impor punição disciplinar ao servidor faltoso à revelia de anterior julgamento no âmbito criminal, ou em sede de ação civil, mesmo que a conduta imputada configure crime em tese.
\end{abstract}

IV - Em relação ao controle jurisdicional do processo administrativo, a atuação do Poder Judiciário circunscreve-se ao campo da regularidade do procedimento, bem como à legalidade do ato demissionário, sendo-lhe defesa qualquer incursão no mérito administrativo, a fim de aferir o grau de conveniência e oportunidade.

V - Descabida a arguição de nulidades quando o "writ" é impetrado como forma derradeira de insatisfação com o robusto e conclusivo desfecho do processo administrativo disciplinar.

7.2.7. Recurso Especial n ${ }^{\circ}$. 429.570/GO, 2a. Turma - Relatora: Eliana Calmon. Julgamento: $11 / 11 / 2003$

Cuida-se de recurso especial interposto contra acórdão do Tribunal de Justiça do Estado de Goiás, proferido em sede de ação civil pública ajuizada pelo Ministério Público do Estado de Goiás, na qual se objetivou a obtenção de ordem judicial para obrigar o Município de Goiânia a promover obras de recuperação da área degradada por 
erosões nas Vilas Maria Dilce e Cristina, que estariam causando danos ao meio ambiente e riscos à população circunvizinha, sob pena de multa diária.

O Tribunal recorrido reconheceu, em princípio, que seria possível condenar o Poder Público a uma obrigação de fazer, através da ação civil pública, mas, por se tratar de ato administrativo de natureza discricionária, o Poder Executivo gozaria de liberdade para decidir sobre a sua conveniência e oportunidade - mérito administrativo -, não sendo possível ao Poder Judiciário estabelecer a prioridade para a realização de obra pública. Como o julgamento da apelação se deu por maioria, foram interpostos embargos infringentes pelo Ministério Público Estadual, e o Tribunal, novamente por maioria, manteve o acórdão embargado, sob os mesmos fundamentos.

O Ministério Público, por sua vez, arguiu que a atividade de conservação e recuperação do meio ambiente corresponde, para a Administração Pública, a um ato administrativo vinculado, conforme os mandamentos dos arts. 23, 30 e 225, da CF/88 e, não, a um ato discricionário, como decidido pelo Tribunal recorrido

A ministra Eliana Calmon, em seu voto, ao analisar a possibilidade de interferência do judiciário nos critérios de conveniência e oportunidade da Administração, ou seja, no chamado mérito administrativo, com a imposição imediata de obrigação de fazer, adotou um posicionamento bastante avançado e inovador, no sentido de que seria possível ao Judiciário o exame da conveniência e oportunidade, já que o caráter de liberdade total do administrador estaria se apagando da cultura brasileira. Destaque-se que constou da ementa deste acórdão, embora não tenha sido mencionado explicitamente no voto da Ministra Relatora, que as razões de conveniência e oportunidade "devem observar princípios da moralidade e da razoabilidade".

Diante desse caráter inovador do voto da Ministra e da importância para o presente estudo, transcreve-se abaixo trecho do voto:

O acórdão recorrido adotou entendimento de que não poderia fazê-lo por se tratar de ato administrativo discricionário, sobre o qual não cabe a ingerência do Judiciário. Não obstante, entendo que a ótica sob a qual se deve analisar a questão não é puramente a da natureza do ato administrativo, mas a da responsabilidade civil do Estado, por ato ou omissão, dos quais decorram danos ao meio ambiente. 
Estando, pois, provado que a erosão causa dano ao meio ambiente e põe em risco a população, exige-se do Poder Público uma posição no sentido de fazer cessar as causas do dano e também de recuperar o que já foi deteriorado.

$\mathrm{O}$ primeiro aspecto a considerar diz respeito à atuação do Poder Judiciário, em relação à Administração. No passado, estava o Judiciário atrelado ao princípio da legalidade, expressão maior do Estado de direito, entendendo-se como tal a submissão de todos os poderes à lei. A visão exacerbada e literal do princípio transformou o Legislativo em um super poder, com supremacia absoluta, fazendo-o bom parceiro do Executivo, que dele merecia conteúdo normativo abrangente e vazio de comando, deixando-se por conta da Administração o facere ou non facere, ao que se chamou de mérito administrativo, longe do alcance do Judiciário.

A partir da última década do Século XX, o Brasil, com grande atraso, promoveu a sua revisão crítica do Direito, que consistiu em retirar do Legislador a supremacia de super poder, ao dar nova interpretação ao princípio da legalidade. Em verdade, é inconcebível que se submeta a Administração, de forma absoluta e total, à lei. Muitas vezes, o vínculo de legalidade significa só a atribuição de competência, deixando zonas de ampla liberdade ao administrador, com o cuidado de não fomentar o arbítrio. Para tanto, deu-se ao Poder Judiciário maior atribuição para imiscuir-se no âmago do ato administrativo, a fim de, mesmo nesse íntimo campo, exercer o juízo de legalidade, coibindo abusos ou vulneração aos princípios constitucionais, na dimensão globalizada do orçamento.

A tendência, portanto, é a de manter fiscalizado o espaço livre de entendimento da Administração, espaço este gerado pela discricionariedade, chamado de "Cavalo de Tróia" pelo alemão Huber, transcrito em "Direito Administrativo em Evolução", de Odete Medauar.

Dentro desse novo paradigma, não se pode simplesmente dizer que, em matéria de conveniência e oportunidade, não pode o Judiciário examiná-las. Aos poucos, o caráter de liberdade total do administrador vai se apagando da cultura brasileira e, no lugar, coloca-se na análise da motivação do ato administrativo a área de controle. E, diga-se, porque pertinente, não apenas o controle em sua acepção mais ampla, mas também o político e a opinião pública.

$\mathrm{Na}$ espécie em julgamento, tem-se, comprovado, um dano objetivo causado ao meio ambiente, cabendo ao Poder Público, dentro da sua esfera de competência e atribuição, providenciar a correção. Ao assumir o encargo de gerir o patrimônio público, também assumiu o dever de providenciar a recomposição do meio ambiente, cuja degradação, provocada pela erosão e o descaso, haja vista a utilização das crateras como depósito de lixo, está provocando riscos de desabamento e assoreamento de córregos, prejudicando as áreas de mananciais.

Com essas considerações, dou provimento ao recurso especial para ordenar que a Administração providencie imediatamente as obras necessárias à recomposição do meio ambiente. 
O Ministro Francisco Peçanha Martins, por sua vez, discordando do voto da Relatora, afirmou continuar fiel às lições de Seabra Fagundes, entendendo que ao Judiciário não cabe julgar a conveniência e a oportunidade dos atos administrativos.

A Turma, por maioria, conheceu do recurso. Votaram com a Ministra Eliana Calmon, os Ministros João Otávio de Noronha e Castro Meira; vencido o Ministro Francisco Peçanha. O acórdão foi assim ementado:

$$
\begin{aligned}
& \text { ADMINISTRATIVO E PROCESSO CIVIL - AÇÃO CIVIL } \\
& \text { PÚBLICA - OBRAS DE RECUPERAÇÃO EM PROL DO MEIO } \\
& \text { AMBIENTE - ATO ADMINISTRATIVO DISCRICIONÁRIO. }
\end{aligned}
$$

1. Na atualidade, a Administração pública está submetida ao império da lei, inclusive quanto à conveniência e oportunidade do ato administrativo.

2. Comprovado tecnicamente ser imprescindível, para o meio ambiente, a realização de obras de recuperação do solo, tem o Ministério Público legitimidade para exigi-la.

3. O Poder Judiciário não mais se limita a examinar os aspectos extrínsecos da administração, pois pode analisar, ainda, as razões de conveniência e oportunidade, uma vez que essas razões devem observar critérios de moralidade e razoabilidade.

4. Outorga de tutela específica para que a Administração destine do orçamento verba própria para cumpri-la.

5. Recurso especial provido.

7.2.8. Recurso Especial no. 575.280/SP, $1^{\text {a }}$. Turma - Relator: Luiz Fux. Julgamento: 2/9/2004

Cuida-se de Ação Civil Pública ajuizada pelo Ministério Público do Estado de São Paulo em face do município de Santo André, visando a criação e manutenção de vagas em creches municipais para criança menores de seis anos, sob pena de multa diária.

O Tribunal de Justiça do Estado de São Paulo rejeitou os embargos infringentes, cuja ementa está abaixo transcrita, confirmando o acórdão da apelação e do reexame necessário, que julgara improcedente o pedido: 
“EMBARGOS INFRINGENTES. - Ação Civil Pública ajuizada pelo Ministério Público em favor de menor - Sentença que julgou procedente pedido voltado à obrigação de fazer, consistente na criação e manutenção de vagas em creches municipais para crianças, menores de seis anos, sob pena de multa diária. Recurso voluntário visando a reforma integral da sentença, sob o fundamento de ingerência no Poder Executivo, concedido, por maioria de votos, pelo V. Acórdão embargado.

Inadmissibilidade da substituição da vontade da Administração Pública - Inviabilidade de exame do mérito administrativo - Os critérios governamentais, conveniência e oportunidade, são próprios do Executivo, não podendo o Judiciário, sob qualquer pretexto, ir além do estrito exame da legalidade e da legitimidade, par e passo dos princípios informadores de cada qual, pena de ingerência no Executivo, se imiscuindo em terreno discricionário específico Desobediência ao orçamento municipal que sequer foi alegada na petição inicial da ação civil pública ajuizada, o que torna a matéria impossível de conhecimento em face da omissão da causa de pedir. Embargos Infringentes rejeitados."

O voto do Ministro José Delgado foi pelo não provimento do recurso, ponderando que a imposição, pelo Judiciário, de obrigação de fazer, consistente na criação e manutenção de vagas em creches municipais para crianças menores de seis anos, constituir-se-ia em invasão de competência, em ingerência indevida na esfera governamental, sublinhando a impossibilidade de o juiz substituir a Administração Pública. .

A conclusão extraída do voto do Ministro José Delgado dá mostras do seu entendimento sobre o tema em questão:

a) há impossibilidade de o juiz substituir a Administração Pública estabelecendo que determinado Município crie e mantenha vagas em creches para menores de 06 anos de idade; b) ao Poder Executivo cabe a conveniência e a oportunidade de realizar atos físicos de administração (construção de conjuntos habitacionais, escolas públicas, creches etc.). O Judiciário não pode, sob o argumento de que está protegendo direitos coletivos, ordenar que tais realizações sejam consumadas; c) as obrigações de fazer permitidas pela ação civil pública não têm força de quebrar a harmonia e independência dos Poderes; d) o controle dos atos administrativos pelo Poder Judiciário está vinculado a perseguir a atuação do agente público em campo de 
obediência aos princípios da legalidade, da moralidade, da eficiência, da impessoalidade, da finalidade e, em algumas situações, o controle do mérito; e) as atividades de realização dos fatos concretos pela administração depende de dotações orçamentárias prévias e do programa de prioridades estabelecido pelo governante. Não cabe ao Poder Judiciário, portanto, determinar as obras que deve edificar, mesmo que seja para proteger o meio ambiente.

Por sua vez, o Ministro Luiz Fux, que substituiu o Ministro José Delgado na Relatoria deste acórdão, destacou que o atendimento em creche e pré-escola ás crianças de zero a seis anos de idade é dever do Estado e direito subjetivo da criança; portanto, para o Ministro, não seria correto alegar discricionariedade do administrador diante desses direitos consagrados constitucionalmente. Na verdade, para ele, trata-se de atividade vinculada, inadmitindo-se qualquer exegese que vise afastar a garantia pétrea.

Interessante a ponderação do Ministro acerca da ideia de que a imposição de obrigação de fazer, com repercussão na esfera orçamentária, implicaria infringência à harmonia dos poderes, afasta essa ingerência indevida, afirmando que "no regime democrático e no estado de direito, o Estado soberano submete-se à própria justiça que instituiu". O Judiciário, na verdade, nada mais fez do que cumprir a lei "ao determinar a realização prática da promessa legal”.

Diante da importância do voto do Ministro Luiz Fux, transcreve-se o trecho abaixo:

Releva notar que uma Constituição Federal é fruto da vontade política nacional, erigida mediante consulta das expectativas e das possibilidades do que se vai consagrar, por isso cogentes e eficazes suas promessas, sob pena de restarem vãs e frias enquanto letras mortas no papel. Ressoa inconcebível que direitos consagrados em normas menores como Circulares, Portarias, Medidas Provisórias, Leis Ordinárias tenham eficácia imediata e os direitos consagrados constitucionalmente, inspirados nos mais altos valores éticos e morais da nação sejam relegados a segundo plano. O que o Estado soberano promete por si ou por seus delegatários é cumprir o dever de educação mediante o oferecimento de creche a crianças entre zero e seis anos. Assim, divergindo do e. Ministro relator, voto no sentido de DAR PROVIMENTO ao presente recurso especial. 
O Ministro Teori Albino Zavascki, acompanhando o voto do Ministro Luiz Fux, deu provimento ao recurso. Iniciou o voto destacando a dificuldade na solução do conflito:

Tem-se presente, aqui, um conflito de difícil solução. De um lado, a norma do art. 208, IV da Constituição, reproduzida no art. 54 do Estatuto da Criança e do Adolescente (Lei 8.069, de 13.07.90), segundo a qual "é dever do Estado assegurar (...) atendimento em cresce e pré-escola às crianças de 0 (zero) a seis anos de idade". $\mathrm{E}$, de outro, a situação financeira do ente estatal, Município de Santo André (SP), a braços com limitações fiscais para dar cumprimento a esse dever, inclusive em face de outras demandas sociais de igual relevância.

Não obstante o Ministro Teori Albino Zavaschi, em seu voto, asseverou que não seria possível afirmar que a norma prevista na Constituição Federal e no Estatuto da Criança e do Adolescente, segundo a qual "é dever do Estado assegurar (...) atendimento em creche e pré-escola às crianças de zero a seis anos de idade (Lei 8.069/90, art. 54, V)", garantiria, imediatamente, um direito subjetivo universal e incondicional de obter essa prestação por parte dos Municípios, no entanto, é imperioso concluir que a norma possui, desde logo, um mínimo de efetividade.

O Ministro Teori Albino Zavaschi ponderou que "por mais elástico que possa ser o campo de atuação discricionária do Município", existe, no conjunto normativo, um chamado mínimo essencial que escaparia ao poder de discrição do Administrador Público e asseguraria o cumprimento imediato, como é o caso das creches para menores de seis anos.

Verifica-se, pelos votos dos Ministros, que existe ainda divergência no entendimento dos mesmos acerca do controle das Políticas Públicas, muito embora seja possível antever uma maior "atuação" do Judiciário.

7.2.9. Recurso Ordinário em MS nº $18.151 / R J, 5^{\mathrm{a}}$. Turma - Relator: Gilson Dipp. Julgamento: 2/12/2004 
Cuida-se, na origem, de mandado de segurança impetrado por policial militar, contra ato omissivo da Exma. Sra. Governadora do Estado do Rio de Janeiro e do Sr. Secretário de Segurança Pública daquele Estado, sustentando que tem direito líquido e certo de receber a gratificação de encargos especiais prevista no Decreto $n^{\circ} 21.743 / 95$, tendo em vista que os bombeiros militares que participaram do mesmo ato de bravura foram agraciados com o benefício, não tendo sido, entretanto, incluídos os policiais militares.

O acórdão do Tribunal de Justiça do Estado do Rio de Janeiro, denegatório do mandado de segurança trouxe a seguinte ementa:

"Mandado de Segurança. Policial Militar da PMERJ. Pedido de gratificação de encargos especiais, por mérito, não concedido. Ato omissivo. Decreto 21753/95 revogado. Preliminar de decadência afastada. Ato discricionário da administração pública. Inexistência de direito, muito menos, líquido e certo a ser amparado por mandado de segurança. Denegação do 'writ'." (fl. 96).

Em seu voto, o Ministro Relator concluiu que da simples leitura do dispositivo da lei em questão, era possível extrair-se que a gratificação de encargos especiais consistia em uma premiação, de caráter individual, por mérito do policial, após o regular reconhecimento e declaração oficial realizados em procedimentos administrativos.

Asseverou o Ministro Relator que a atuação do Judiciário quanto ao direito à concessão do benefício por ato de bravura, caracterizar-se-ia em invasão do espaço reservado pela lei ao administrador, em ingerência no mérito administrativo.

Os Ministros da $5^{\text {a }}$. Turma, por unanimidade, negaram provimento ao recurso.

Nesse mesmo sentido, da impossibilidade de o Judiciário sindicar o mérito do ato administrativo, são os acórdãos abaixo, citados pelo Ministro Gilson Dipp em seu voto:

RECURSO ESPECIAL. ADMINISTRATIVO. SERVIDORA PÚBLICA. REMOÇÃO PARA ACOMPANHAR CÔNJUGE EMPREGADO DA INICIATIVA PRIVADA. INDEFERIMENTO. ART. 36, PARÁGRAFO ÚNICO, DA LEI 8.112/90. INTERPRETAÇÃO SOB A ÓTICA DO DIREITO ADMINISTRATIVO. DESRESPEITO AO PRINCÍPIO DA 
SUPREMACIA DO INTERESSE PÚBLICO E AO PODER DISCRICIONÁRIO DA ADMINISTRAÇÃO.

I - Segundo a doutrina e jurisprudência, a interpretação dos atos administrativos deve levar em conta seus princípios basilares. Dentre eles, destaca-se o da supremacia do interesse público, que só poderá ser mitigado em caso de expressa previsão legal. Desta feita, é defeso ao Poder Judiciário adentrar ao mérito administrativo, a fim de aferir sua motivação, oportunidade em que só lhe é permitido analisar eventual transgressão do diploma legal.

II - Nesse diapasão, equivocada a ingerência do Judiciário aos motivos determinantes do ato administrativo, que indeferiu a remoção de servidora pública federal para acompanhar seu cônjuge, empregado da iniciativa privada, pois a interpretação sistemática da Lei 8.112/90, veda a preponderância do interesse particular sobre o público. Indispensável o respeito ao Poder Discricionário da Administração. Precedente: MS 21.978-5/DF - STF. III- Recurso especial conhecido e provido." (RESP 187904/SC, Gilson Dipp, DJ de 04.06.2001).

ADMINISTRATIVO - SERVIDOR PÚBLICO - REMOÇÃO EX OFFICIO INTERESSE DA ADMINISTRAÇÃO - MOTIVAÇÃO DO ATO CARÁTER PUNITIVO - INEXISTTÊNCIA - IMPOSSIBILIDADE DE ANÁLISE PELO PODER JUDICIÁRIO DO MÉRITO ADMINISTRATIVO - RECURSO DESPROVIDO.

(omissis).

V - Impossibilidade de qualquer incursão, por parte do Poder Judiciário, no mérito administrativo a fim de aferir o grau de conveniência e oportunidade.

VI - Recurso desprovido." (ROMS 15734/PR, Gilson Dipp, DJ de 06.09.2004).

"ADMINISTRATIVO - MANDADO DE SEGURANÇA - SERVIDORA
PÚBLICA FEDERAL - NOMEAÇÃO PARA CARGO EM COMISSÃO -
PRETERIÇÃO - INEXISTENNCIA - OFENSA AOS PRINCÍPIOS DA
RAZOABILIDADE E ISONOMIA NÃO DEMONSTRADOS - ATO
DISCRICIONÁRIO - ILEGALIDADE - INOCORRÊNCIA - DIREITO
LÍQUIDO E CERTO INEXISTENTE - SEGURANÇA DENEGADA.

1 - Não há que se falar em preterição ou ilegalidade quanto à nomeação para cargo em comissão, tendo em vista que tal designação configura ato administrativo discricionário, submetido exclusivamente à conveniência e oportunidade da autoridade pública competente, de livre nomeação e exoneração, considerada a relação de confiança entre o nomeado e o seu superior hierárquico, não podendo o Judiciário adentrar-se no meritum adotado pelo mesmo. Precedente (RMS 15.056/BA).

2 - Ausência de direito líquido e certo a ser amparado.

3 - Segurança denegada. Custas ex lege. Sem honorários advocatícios a teor das Súmulas 512/STF e 105/STJ." (MS 9181/DF, Relator Ministro JORGE SCARTEZZINI, DJ de 08.03.2004). 


$\begin{array}{llcccc}\text { "ADMINISTRATIVO } & - & \text { CONTROLE } & \text { JUDICIAL } & \text { DO } & \text { ATO } \\ \text { DISCRICIONÁRIO } & \text { EXAME DO } & \text { MÉRITO } & \text { DO } & \text { ATO } \\ \text { ADMINISTRATIVO - IMPOSSIBILIDADE. } & & & \end{array}$

Compete à Administração Estadual o poder discricionário de decidir sobre o deferimento ou não do pedido de adesão ao PDV. Não pode o Poder Judiciário substituir $\mathrm{o}$ administrador, decidindo sobre a conveniência e oportunidade do ato discricionário.

Recurso improvido." (ROMS 9319/MG, Relator Ministro GARCIA VIEIRA, DJ de 12.04.1999).

RESP - PROCESSUAL CIVIL - ADMINISTRATIVO - ATO ADMINISTRATIVO - DISCRICIONARIEDADE - OS MODERNOS PRINCIPIOS DE ACESSO AO JUDICIARIO RECOMENDAM APLICAÇÃO DO PRINCIPIO DA FUNGIBILIDADE DOS RECURSOS. O ATO ASPECTO FORMAL NÃO DEVE SER APLICADO DE MODO INTRANSIGENTE.

O ATO ADMINISTRATIVO, QUANTO AO MERITO, E INSUSCEPTIVEL DE REEXAME DO JUDICIARIO, EM DECORRENCIA DA SEPARAÇÃO DOS PODERES. A DISCRICIONARIEDADE DO ATO NÃO SE CONFUNDE COM ILEGALIDADE. (RESP 69735/SP, Relator Ministro LUIZ VICENTE CERNICCHIARO, DJ de 15.04.1996).

7.2.10. Recurso em Mandado de Segurança ${ }^{\circ}$. 19.210/RS, $5^{\mathrm{a}}$. Turma - Relator: Felix Fischer. Julgamento: $14 / 3 / 2005$

Neste acórdão, o Ministro Felix Fischer destacou a essencialidade da motivação nos atos administrativo, sublinhando que não atenderia a essa exigência a indicação de conceitos jurídicos indeterminados, em relação aos quais a Administração limitou-se a conceituar o desempenho de servidor em estágio probatório como bom, regular ou ruim, sem, todavia, apresentar os elementos que conduziram a esse conceito.

Trata-se de recurso ordinário em mandado de segurança impetrado contra acórdão do Tribunal de Justiça do Estado do Rio Grande do Sul, que confirmou a nãoefetivação do servidor e sua consequente exoneração. Consta do acórdão hostilizado, que a exoneração fora decretada após regular procedimento administrativo, instaurado para apurar a conveniência do servidor no cargo; que não houve ilegalidade; que se tratava de ato discricionário da administração e que seria vedado ao Judiciário examinar o mérito do ato administrativo. 
Em seu voto, o Ministro deu especial destaque à obrigatoriedade da motivação dos atos administrativos, afirmando que "a motivação torna-se o instrumento capaz de detectar e afastar providências oriundas de favoritismos, perseguições, enfim, o não atendimento aos interesses públicos consagrados na ordem jurídica”. Seria também a motivação a responsável por fazer a ligação entre meios e fins e por preservar os princípios da razoabilidade e proporcionalidade.

Asseverou o Ministro que se o motivo é o pressuposto fático que condiciona o ato, sendo indispensável para sua validade, não menos necessária é a motivação, vez que sem esta, tornar-se-ia impossível a verificação da existência dos motivos que deram sustentação ao ato, ou seja, se foi legítimo ou não. "Menos ainda, poder-se-á constatar se compareciam razões juridicamente idôneas para justificar o ato ante a finalidade legal”. Fez também uma analogia entre o princípio da legalidade e a motivação, ponderando que,

o princípio da legalidade resulta na obrigatoriedade da conformidade do ato com a lei, portanto, curial a demonstração de que aquele se orientou pelo atendimento aos interesses públicos estabelecidos na ordem jurídica. Da mesma forma, exige-se a motivação para assegurar a moralidade administrativa, pois, caso contrário, não seria possível verificar as condutas imorais dos agentes públicos.

Entendeu o Ministro que os relatórios de avaliação de desempenho do servidor, de acordo como voto do Ministro, não atenderam a essa necessidade de devida motivação, vez que indicaram apenas um conceito jurídico indeterminado, citando como por exemplo, "discrição", em relação ao qual a Administração limitou-se a conceituar em bom, regular ou ruim, sem apresentar os dados que conduziram a esse conceito. Não houve a apresentação de dados concretos que permitiriam chegar a essa conclusão, além de não ter sido realizada avaliação durante certo período. O Ministro deixou também claro a possibilidade de controle jurisdicional sobre os conceitos jurídicos indeterminados, citando, o acórdão relativo ao RMS $\mathrm{n}^{\circ}$. 19.590, no qual admite a "viabilidade do controle do Poder Judiciário acerca de conceitos jurídicos indeterminados e do motivo do ato administrativo". 
Concluindo o voto, o Ministro deu provimento ao recurso ordinário, no que foi acompanhado pelos demais Ministros da $5^{\text {a }}$. Turma.

7.2.11. AgRg nos EDcl no Recurso em Mandado de Segurança no ${ }^{\circ} .17 .718,6^{a}$. Turma Relator: Paulo Medina. Julgamento: 11/4/2006

Este acórdão deu também especial relevo à motivação dos atos administrativos. Sua ementa deixa claro o entendimento dos Ministros, de que todos os atos administrativos são passíveis de controle jurisdicional (art. $5^{\circ}$., XXXV, CR/88) e que esse controle, em especial nos atos discricionários, é feito por meio da motivação, como condição de sua própria validade.

Cuida-se, na origem, de mandado de segurança impetrado contra ato do Secretário de Administração e Recursos Humanos do Estado do Acre, que invalidara teste de aptidão física realizado pelo autor para o cargo de Agente da Polícia Civil, depois de aprovado na primeira e na segunda etapa do concurso e já ter, inclusive, se matriculado no curso de formação profissional.

Tendo em vista a alegação do autor de que a anulação do teste físico teria ocorrido por ato sem a devida motivação, com desrespeito às garantias do contraditório e da ampla defesa, o Ministro Paulo Medina, em seu voto, destacou, primeiramente, que o modelo democrático no qual se insere o Estado brasileiro consagrou que todo o agir administrativo deve ser legitimado pela ideia de procedimentalização, o que quer dizer que aquela "antiga noção de que a atividade administrativa se desenvolve por meio de ato administrativo, concebido em isolado, vem sendo, felizmente, substituída pela ideia de submissão da ação estatal a determinado procedimento".

Segundo o Ministro, não seria possível admitir a invalidação de atos administrativos, sobretudo os classificados como ampliativos de direitos, sem a observância de um processo administrativo, já que, “desde a promulgação da Carta de 88, a atividade administrativa encontra-se subordinada ao devido procedimento administrativo, por força do art. $5^{\circ}$, incisos LIV e LV'. Para o Ministro, o ato impugnado ofendeu os princípios da legalidade e da moralidade administrativas, no 
momento em que desrespeitou as garantias constitucionais do contraditório e da ampla defesa do interessado.

Acerca do controle do mérito do ato administrativo pelo Judiciário, afirmou o Relator que "há muito a jurisprudência dos nossos Tribunais tem aceitado o controle do chamado mérito do ato administrativo, pelo Poder Judiciário". Nenhum ato praticado pelo poder público, num Estado Democrático de Direito, pode escapar do controle jurisdicional, como garantia também constitucional que é, nos termos do art. $5^{\circ}$, inciso $\mathrm{XXXV}$. Os atos discricionários estariam também sujeitos ao controle, "porquanto discricionariedade, hodiernamente, só se entende como exercício da oportunidade e da conveniência administrativa, nos limites da lei”

Sublinhou o Ministro que o controle somente se faz possível pela devida motivação e, é por meio dela que o Poder Judiciário torna eficaz o controle da discricionariedade administrativa. Para ele, a ausência de motivação nos atos discricionários seria ainda mais grave do que a ausência de motivação nos atos vinculados. Para o Ministro Paulo Medina, nos atos vinculados a motivação poderia ser posterior à prática do ato, enquanto nos atos discricionários, não, o que implicaria a necessidade de sua invalidação, em razão da ausência de motivação tempestiva.

Entendeu o Ministro que a decisão agravada não substituiu aquela dada pelo Administrador Público, já que o Judiciário apenas invalidou o ato viciado, deixando à Administração a oportunidade de praticar novamente o ato, expondo os motivos e garantindo o contraditório e a ampla defesa ao interessado.

Como se vê apenas se resguardou a legalidade do ato, sem substituirlhe a vontade defeituosa. Por conseguinte, não se podendo cogitar de ofensa ao princípio da separação dos poderes no caso, pois a atuação desse julgador foi, não somente, possível, como necessária, no cumprimento de suas funções jurisdicionais.

A Turma, por unanimidade, negou provimento ao agravo regimental.

7.2.12. Habeas Corpus nº. 56.986/SP, $1^{\text {a }}$. Seção - Relator: Luiz Fux. Julgamento: 23/8/2006 
Neste acórdão, o Ministro Luiz Fux deixa claro por meio da citação de doutrina e jurisprudência do Tribunal não caber ao Poder Judiciário o exame da conveniência e oportunidade de ato do Poder Executivo, consistente na expulsão de estrangeiro. A competência do Judiciário ficaria restrita à apreciação formal e à constatação da inexistência de vícios de nulidade do ato de expulsão.

Cuida-se este caso de habeas corpus contra ato do Ministro da Justiça que determinou a expulsão do paciente do território Nacional (art. 65, Lei nº 6.815/80) pela condenação por prática de crime de extorsão. O paciente encontrava-se recolhido à carceragem da Polícia Federal de São Paulo aguardando as formalidades legais para cumprimento do decreto de expulsão e ingressara também com pedido de revisão criminal perante o Tribunal de Justiça do Estado de São Paulo. Acaso se consumasse a expulsão antes do julgamento da revisão criminal restaria negado a ele o exercício da ampla defesa e do contraditório. Pretendia assim, a revogação do decreto de expulsão. $\mathrm{O}$ STJ denegou a ordem, por unanimidade, revogando a medida liminar anteriormente deferida.

No que interessa à pesquisa, o voto do Ministro Luiz Fux, deixou claro que a consumação da ordem de expulsão com base em causa legal que a justifique, é calcada em razões da conveniência da Autoridade Administrativa e, dessa forma, não poderia ser sustada por revisão criminal pendente de julgamento.

Assentou também o Relator que a expulsão é ato discricionário, de competência do Presidente da República, e só a ele caberia analisar e julgar a conveniência e oportunidade da medida, não o judiciário. O Ministro citou os acórdãos, HC 73.940 SP, Relator Ministro MAURÍCIO CORRÊA, Tribunal Pleno, DJ de 26 de junho de 1.996; HC 72.082 - RJ, Relator Ministro FRANCISCO REZEK, Tribunal Pleno, DJ de $01^{\circ}$ de março de 1.996; HC 16.819 - PA, Relator Ministro FRANCISCO PEÇANHA MARTINS, Primeira Seção, DJ de 15 de abril de 2.002, cujas decisões são no mesmo sentido do voto do Ministro Luiz Fux.

No caso de expulsão de estrangeiro, pela análise dos acórdãos, verifica-se que o Superior Tribunal de Justiça procura ater-se à apreciação formal do ato e sua adequação à legislação vigente; abstendo-se de adentrar na análise da conveniência e oportunidade do Decreto de expulsão. “Ao Judiciário compete tão somente a apreciação formal e a 
constatação da existência ou não de vícios de nulidade do ato expulsório, não o mérito da decisão presidencial”. Os acórdãos são claros neste sentido.

7.2.13. Recurso em MS n ${ }^{\circ}$. 19.741/MT, $5^{\text {a }}$. Turma - Relator: Felix Fischer. Julgamento: $11 / 3 / 2008$

Neste acórdão o Ministro Relator Felix Fischer aborda uma questão de suma importância relativa à inexistência de discricionariedade nos atos que envolvem sanções disciplinares, o que permitira, segundo posição do Ministro, um amplo controle jurisdicional. Esse entendimento foi também adotado pelo Supremo Tribunal Federal no voto proferido pelo Ministro Castro Nunes, nos autos dos Embargos à Apelação Cível n. 7307, 1944 - STF - Pleno, cuja análise encontra-se às folhas 82, deste trabalho.

Trata-se, na origem, de mandado de segurança impetrado por servidor contra ato do Governador do Estado de Mato Grosso, que o demitiu do cargo de Fiscal de Tributos Estaduais. O Tribunal de Justiça do Mato Grosso denegou a ordem, tendo sido, então, manejado o recurso em questão.

O Ministro, em seu voto, lança uma questão importante, que diz respeito à não existência de discricionariedade no ato que impõe sanção a servidor, afirmando:

Resta saber se é possível admitir, no ato que impõe sanção a servidor público, espaço para discricionariedade administrativa. Ou melhor, e para nos aproximarmos do caso concreto: o ato de demissão de cargo público viabiliza juízo de conveniência e oportunidade capaz de limitar o respectivo controle jurisdicional? Ao reexaminar essa questão, penso que deve ser afastada a tese de que existiria discricionariedade administrativa no ato que resulta em sanção a servidor público.Valho-me, para tanto, do regime jurídico disciplinar, cujos contornos encontram-se na própria Constituição Republicana de 1988: princípios da dignidade da pessoa humana, legalidade, culpabilidade, proporcionalidade e prestação jurisdicional acerca da violação a direito (art. $5^{\circ}$, inciso XXXV). 
Para o Ministro, da mesma forma que se exige a demonstração de dolo ou culpa do servidor público para que se possam cobrar os prejuízos por ele causados, por maior razão dever-se-ia exigir a demonstração de tais elementos quando estivesse sendo imposta sanção disciplinar. Segundo o Relator, seriam critérios como esses que condicionariam o ato disciplinar e não mero juízo de conveniência (dito mérito administrativo) que poderia limitar o controle jurisdicional acerca da matéria.

Sublinhou, citando precedentes da própria $3^{\text {a }}$. Seção (MS n. 10827/DF, Rel. Min. HÉliO QUAGLIA, julgamento: 6.2.2006; e, MS n. 10828, Rel. Min. PAULO GALLOTTI, julgamento: 28.06.2006) que, com base no princípio da proporcionalidade, anularam sanções impostas a servidores públicos. "Dessa forma, acabou-se por reconhecer que ao Judiciário cabe controlar o ato disciplinar não apenas em aspectos referentes ao devido processo legal formal, como, também, no que diz respeito ao "mérito intrínseco, ou seja, de sua justiça ou injustiça" (OROSIMBO NONATO, 1944)".

Assentou, por fim, seu entendimento no sentido da possibilidade de anulação de sanções disciplinares com base em princípios constitucionais.

Em consonância à sua tese, cita precedente de sua lavra, adotado no mandado de segurança $\mathrm{n}^{\circ}$. 12.983/DF julgado em 15/2/2008:

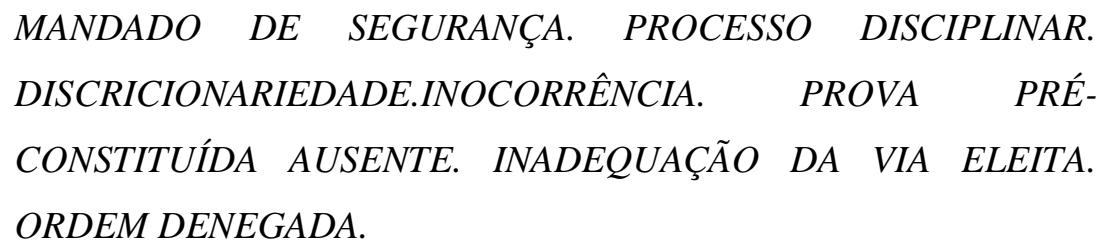

I - Tendo em vista o regime jurídico disciplinar, especialmente os princípios da dignidade da pessoa humana, culpabilidade $e$ proporcionalidade, inexiste aspecto discricionário (juízo de conveniência e oportunidade) no ato administrativo que impõe sanção disciplinar.

II - Inexistindo discricionariedade no ato disciplinar, o controle jurisdicional é amplo e não se limita a aspectos formais.

[...] (MS 12983/DF, Rel. Ministro FELIX FISCHER, TERCEIRA SEÇÃO, julgado em 12.12.2007, DJ 15.02.2008 p. 1) 
Foi dado provimento ao recurso, por unanimidade.

7.2.14. Recurso Especial n ${ }^{\circ}$. 778.648/PE, $2^{\mathrm{a}}$. Turma - Relator: Mauro Campbell Marques. Julgamento: $6 / 11 / 2008$

Neste acórdão admitiu-se o controle do mérito do ato administrativo (conveniência e oportunidade) no caso de ofensa ao princípio da razoabilidade, já que ao extrapolar os limites da razoabilidade, acaba violando a própria legalidade.

Trata-se de recurso especial interposto pela Fazenda Nacional contra acórdão do Tribunal Regional Federal da $5^{\mathrm{a}}$. Região, que considerou como cerceamento de defesa a negativa de realização de prova pericial em processo administrativo para fins de enquadramento de produtos à alíquota zero de IPI.

Para o Relator, a subsunção de determinado insumo ou matéria-prima ao regime de alíquota zero, isenção ou não-tributação não é uma questão de conveniência e oportunidade da Administração, uma vez que, estando o produto enquadrado na hipótese da lei, devem incidir a consequência previstas. Asseverou o Ministro, que a prova pericial era imprescindível para demonstrar o cumprimento do substrato fático da norma e a oposição da Administração viola o direito subjetivo constitucional do administrado ao devido processo legal. Para ele, tem-se, neste caso, clássica situação em que, "a pretexto de um juízo de conveniência e oportunidade, o Poder Público acaba indo de encontro à legalidade".

Sublinha o Relator que, hoje em dia, parte da doutrina e da jurisprudência já admite que o Poder Judiciário possa controlar o mérito do ato administrativo (conveniência e oportunidade) sempre que, no uso da discricionariedade admitida legalmente, a Administração Pública agir contrariamente ao princípio da razoabilidade. Assim, ao extrapolar os limites da razoabilidade, a Administração acaba violando a própria legalidade, que, por sua vez, deve pautar a atuação do Poder Público, segundo ditames constitucionais (notadamente do art. 37, caput).

Negou provimento ao recurso, no que foi acompanhado pelos demais Ministros. 
O interesse por este julgado reside no fato de que o próprio Judiciário, na figura do Juiz de Direito substituto, é que atua administrativamente na prática do ato administrativo discricionário.

Cuida-se, originariamente, de Mandado de Segurança impetrado contra decisão do juiz substituto da Comarca de Aragarças, que afastara o oficial titular do Cartório de Registro de Imóveis local, determinando a instauração de processo administrativo contra o mesmo e nomeando um interventor para responder pelo Cartório, em detrimento da impetrante, oficiala substituta, que era esposa do oficial afastado. $\mathrm{O}$ Tribunal de Justiça, por unanimidade, denegou a segurança, nos termos do acórdão abaixo transcrito:

MANDADO DE SEGURANÇA - DIREITO LÍQUIDO E CERTO. INEXISTÊNCIA ATO DISCRICIONÁRIO. SERVENTIA NÃO OFICIALIZADA. VACÂNCIA DO CARGO. NOMEAÇÃO DE SUBSTITUTO.

I. Não ofende direito líquido e certo a designação de suboficial juramentado, nomeado pelo juiz diretor do foro, para responder provisoriamente pelo expediente do cartório, no lugar

do oficial titular afastado.

II. Mostra-se legal o ato da autoridade que, usando de discricionariedade, aplicou solução eficaz prevista no art. $36, \S 1^{\circ}$ da Lei $\mathrm{n}^{\circ} 8.935$ de 18/11/1994, para viabilizar medida extrema adotada.

III. Inexistindo direito líquido e certo a ser protegido por mandado de segurança é de se denegar a ordem

O Ministro Luiz Fux destacou que a substituição de notários e oficiais de registro supostamente faltosos seria disciplinada pelo art. 36 , $\S 1^{\circ}$, da Lei $n^{\circ} 8.935 / 1994$, que permitiria ao julgador, ao exercer o juízo de discricionariedade, diante da apuração de faltas imputadas aos notários ou oficiais de registro, designar um interventor, notadamente, quando o substituto fosse acusado de faltas ou quando a medida se revelasse conveniente para os serviços.

O Relator asseverou o seu entendimento pela insindicabilidade dos atos discricionários pelo Poder Judiciário: “é sabido que os atos discricionários legitimam 
espaço de liberdade para o administrador, insindicável pelo Poder Judiciário, porquanto nessas hipóteses interditada a intervenção no mérito do ato administrativo".

Concluiu seu voto afirmando que a decisão proferida pelo Juiz de Direito constituía-se em típico ato discricionário fundado em lei, que a autoridade agira dentro dos limites impostos pela lei e que, dentre as várias possibilidades de solução, acolhera a que melhor correspondera ao desejo da lei.

A Turma, por unanimidade, negou provimento ao recurso.

7.2.16. Recurso Especial n $n^{\circ}$ 1.279.607/PR, $2^{\mathrm{a}}$. Turma - Relator: Mauro Campbell Marques. Julgamento: 6/12/2011

Neste recurso, o Ministro Mauro Campbell Marques posicionou-se pela possibilidade de um controle amplo dos atos administrativos pelo Judiciário, em razão de vigorar no Brasil a inafastabilidade do controle jurisdicional.

Cuida-se, na origem, de agravo de instrumento, interposto no âmbito de ação movida por associação indígena, contra decisão que deferiu tutela antecipada para o fim de determinar que o Ibama apenas concedesse licenciamento ambiental a empreendimento de derrocamento de rochas sub-aquáticas localizadas no Rio Paraná após realização e conseqüente análise criteriosa do EIA/Rima, a ser levado a cabo e custeado pelos empreendedores (União e DNIT).

O acórdão recorrido acolheu a tese no sentido de que caberia ao Ibama, no exercício de sua discricionariedade administrativa, definir sobre o cabimento ou não do licenciamento ambiental, não podendo o Poder Judiciário imiscuir-se nesta decisão.

Em seu voto, o Ministro afirmou claramente que os atos administrativos, incluindo os discricionários, são sindicáveis pelo Judiciário, vez que no Brasil vige a inafastabilidade do controle jurisdicional. Para ele, salvo em casos excepcionalíssimos (como, por exemplo, os consagrados atos nitidamente políticos), todo e qualquer ato é, a princípio, controlável pelo Judiciário. 
"Nesta lógica, se é verdade que ao Ibama compete avaliar a necessidade de realização de EIA/Rima, não é menos verdade que qualquer conclusão a que chegue a referida autarquia é sindicável na via judicial. É de pelo menos muito duvidosa a afirmação, feita peremptoriamente no acórdão recorrido em corroboração ao que disse o DNIT, ora recorrido, de que os atos praticados no âmbito do licenciamento ambiental são marcados por alta discricionariedade administrativa. Se isso é correto em face de alguns atos, trata-se de conclusão inteiramente inadequada em face de outros. É que a simples utilização de conceitos indeterminados não é suficiente para conferir a qualquer escolha administrativa a correção. Ao contrário, a utilização deste tipo de técnica de construção normativa tem por escopo possibilitar que a Administração identifique, na análise casuística, qual é a melhor escolha - que, por ser a melhor, é única".

\section{$(\ldots .$.}

(...) mesmo que se admitisse estar diante de um ato eminentemente discricionário, alegar que o confronto judicial do mesmo seria inviável equivale a sustentar, em última linha, que a legislação vigente retirou do poder judiciário a possibilidade de analisar impugnações aos mais diversos atos administrativos, o que é inconstitucional, em face do que dispõe o art. $5^{\circ}$, inc. xxxv, da Constituição da República”.

A Turma, por unanimidade, deu parcial provimento ao recurso, nos termos do voto do Ministro-Relator.

7.2.17. Recurso em MS nº 35.411/BA, $2^{\mathrm{a}}$. Turma - Relator: Humberto Martins. Julgamento: $6 / 3 / 2012$

Cuida-se de recurso ordinário interposto em razão da denegação da segurança, que visava a anulação do processo administrativo, sob a alegação de prescrição, retroatividade na aplicação da lei, falta de competência do Secretário Estadual para a aplicação da penalidade e desproporcionalidade da penalidade. 
Consta do voto do Ministro Relator que o recorrente, como delegado da polícia civil, teria se comportado de forma inconveniente e se prevalecido, abusivamente, do seu cargo de delegado, em face da autoridade policial que se encontrava em serviço, por ocasião da detenção do irmão do recorrente.

O relatório final da comissão processante concluiu pela absolvição. Remetido o processo para a Procuradoria-Geral do Estado, esta opinou no mesmo sentido. Foi, então, o processo remetido para a Corregedoria, que concluiu de forma diversa e sugeriu a aplicação da penalidade disciplinar de suspensão por cinco dias. O Corregedor-Geral da Secretaria de Segurança Pública corroborou e aprovou o parecer da Corregedoria.

Para o presente estudo interessa a análise do Ministro acerca da alegação de malferimento da proporcionalidade e da razoabilidade na punição disciplinar, sobre a qual concluiu que, "a penalidade encontra amparo legal na legislação estadual, bem como os fatos dos autos foram devidamente ponderados e motivados pelas autoridades que se pronunciaram no processo disciplinar".

Sublinhou o Ministro Relator que a penalidade aplicada mostra-se sem vícios e de acordo com as provas que compõem o processo administrativo disciplinar.

Concluiu o Ministro que "não é demais lembrar que a revisão judicial dos processos disciplinares não possui o objetivo de re-apreciar o mérito administrativo. $\mathrm{O}$ exame pauta-se pela juridicidade da penalidade que foi aplicada”.

A Turma, por unanimidade, negou provimento ao recurso ordinário, nos termos do voto do Relator.

7.2.18. AgRg no AgRg no Recurso Especial n ${ }^{\circ} .1 .213 .843 / P R, 1^{a}$. Turma - Relator: Napoleão Nunes Maia Filho. Julgamento: 28/8/2012

O acórdão em questão, cuja relatoria ficara a cargo do Ministro Napoleão Nunes Maia Filho, colocou o tema do controle dos atos discricionários pelo Judiciário nos termos de que esse dogma da antiga doutrina, que pregava que seria vedado ao Poder Judiciário analisar o mérito dos atos administrativos, não poderia mais ser aceito. Um 
breve resumo do andamento deste processo, entretanto, demonstra a diversidade de entendimento do próprio Judiciário, com relação ao controle do ato discricionário:

A impetrante ajuizou Mandado de Segurança com pedido de liminar em face da $\mathrm{OAB} / \mathrm{PR}$, tendo em vista o desprovimento de seu Recurso Administrativo manejado contra a correção de sua prova na $2^{\mathrm{a}}$. fase do exame da Ordem. Em primeira instância, a Magistrada denegou a segurança, sob o fundamento de que não caberia ao Juiz substituir a Comissão Revisora na aferição das questões, destacando que competiria ao Judiciário analisar apenas o aspecto da legalidade do processo seletivo. O Tribunal de origem, por sua vez, deu provimento ao apelo da impetrante, por maioria, para determinar a revisão da sua pontuação na prova prático-profissional, com a consequente tramitação de seu exame da Ordem, com a nota revisada. Asseverou a competência do Poder Judiciário para validar os atos administrativos discricionários. No julgamento do Apelo Nobre, deu-se provimento ao recurso para restabelecer o decisum de primeiro grau, reafirmando a limitação da competência do Poder Judiciário em matéria de concurso público, que se atém ao exame de legalidade das normas instituídas no Edital e dos atos praticados na realização do certame, sendo vedado o exame dos critérios de correção de provas e de atribuição de notas aos candidatos. (grifo não existente no original)

Trata-se de Agravo Regimental interposto pela Ordem dos Advogados do Brasil Seccional do Paraná em face de decisão que deu provimento ao Agravo Regimental, a fim de negar seguimento ao Recurso Especial da ora agravante, nos termos da seguinte ementa:

AGRAVO REGIMENTAL. EXAME DA OAB. REVISÃO DE QUESTÃO SUBJETIVA REFERENTE À SEGUNDA FASE. LIMINAR CONCEDIDA E CONFIRMADA PELO TRIBUNAL A QUO (TRF DA 4A. REGIÃO). ALEGAÇÃO DE INCURSÃO DO PODER JUDICIÁRIO NO CHAMADO MÉRITO ADMINISTRATIVO. SITUAÇÃO CONSOLIDADA POR FORÇA DE DECISÃO JUDICIAL PROFERIDA HÁ MAIS DE 6 ANOS. AUSÊNCIA DE PREJUÍZO AO PODER PÚBLICO E A QUEM QUER QUE SEJA. AGRAVO PROVIDO PARA NEGAR PROVIMENTO AO RECURSO ESPECIAL. 
Nas razões do Regimental, sustentou a $\mathrm{OAB}$, além da impossibilidade da aplicação da teoria do fato consumado, tendo em vista o caráter provisório da decisão que concedera a segurança; que seria vedado ao Poder Judiciário invadir o mérito administrativo, em clara substituição à banca examinadora do concurso público, vez que a resposta exigida, entendida como a melhor das respostas possíveis, segundo os critérios de conveniência e oportunidade, fora cobrada de todos os candidatos da área, indistintamente, possuindo como objetivo primordial verificar a capacidade do bacharel no exercício da atividade advocatícia.

O Ministro Relator, Napoleão Nunes Maia Filho, sublinhou que o efeito temporal, ou seja, mais de seis anos, impunha que se mantivesse o acórdão do Tribunal de origem que determinou a revisão da pontuação na prova prático-profissional da ora agravada, com a consequente tramitação de seu exame da Ordem, com a nota revisada. Para o Ministro, "não há negar que o préstimo da jurisdição produz efeitos consistentes, que somente devem ser desconstituídos se a sua manutenção lesar gravemente a parte desfavorecida ou a ordem jurídica; não se afastam os efeitos da decisão quando não presentes essa lesão ou essa ameaça de lesão".

Como acima destacado, fez o Ministro uma interessante observação quanto ao que ele chamou de antiga doutrina, que entendia pela impossibilidade de o Judiciário analisar o mérito dos atos da Administração, afirmando que tal entendimento não poderia mais ser aceito como dogma, por ser incompatível com o atual estágio de desenvolvimento da Ciência Jurídica.

Outrossim, a antiga doutrina que vedava ao Judiciário analisar o mérito dos atos da Administração, que gozava de tanto prestígio, não pode mais ser aceita como dogma ou axioma jurídico, eis que obstaria, por si só, a apreciação da motivação daqueles atos, importando, ipso facto, na exclusão apriorística do controle dos desvios e abusos de poder, o que seria incompatível com o atual estágio de desenvolvimento da Ciência Jurídica e do seu propósito de estabelecer controles sobre os atos praticados pela Administração Pública, quer sejam vinculados (controle de legalidade), quer sejam discricionários (controle de legitimidade)". 
A Turma, por unanimidade, negou provimento ao agravo regimental, nos termos do voto do Ministro Relator.

7.2.19. Recurso em MS no $37.964 / C E, 2^{a}$. Turma - Relatora: Eliana Calmon, DJE 30/10/2012.

A ementa deste acórdão explicitou não caber ao Poder Judiciário adentrar no mérito do ato administrativo para rever o juízo de conveniência e oportunidade da autoridade tida como coatora, ressalvando os casos de abuso de autoridade ou teratologia.

Trata-se, na origem, de mandado de segurança impetrado contra ato do Secretário de Segurança Pública e Defesa da Cidadania do Estado do Ceará e do Secretário de Planejamento e Gestão do Estado do Ceará, consubstanciado na exclusão da impetrante de concurso público destinado ao preenchimento de vagas para o cargo de Delegado de Polícia Civil do Estado do Ceará.

A recorrente fora excluída do concurso para provimento de vagas para o cargo de Delegado da Polícia Civil do Estado do Ceará, com base no inquérito-policial nº. 317/0007/2007, que concluiu pela possível pratica do crime de falsidade ideológica e uso de documento falso. Da denúncia oferecida consta que a impetrante apresentara à comissão do concurso, na fase de apresentação de títulos, duas obras contendo diversos trechos copiados de outros autores, sem que nenhum deles tenha sido mencionado no texto ou na bibliografia. No decorrer do concurso sobreveio a sentença absolutória, confirmada em grau de apelação.

Em seu voto, ressaltou a Ministra que as esferas penal e administrativa são absolutamente independentes, estando a Administração vinculada apenas à decisão do juízo criminal que negar a existência dos fatos ou a autoria do crime. Segundo a Ministra, entretanto, não houve negativa quanto à existência dos fatos, que considerou que tais condutas, na forma como praticadas, não constituiriam crime. Ressaltou, entretanto, que 
a conclusão do Inquérito Policial não se restringiu ao possível plágio de obras literárias, mas a um conjunto de fatores indicativos de fraude em concurso público, a exemplo do fato de que boa parte das obras analisadas, de suposta autoria dos investigados, foram impressas na mesma editora, em reduzido número de exemplares e em data próxima à realização da quarta fase do certame.

A posição da Ministra ao negar provimento ao recurso, conforme já assinalado acima, foi a de não caber ao Poder Judiciário, salvo em caso de ilegalidade, defeito de forma, abuso de autoridade ou teratologia, adentrar no mérito do ato administrativo revendo o juízo de conveniência e oportunidade da autoridade tida como coatora.

No que tange ao posicionamento do Tribunal de que não cabe a exclusão de candidato apenas pelo fato de figurar como indiciado em inquérito policial ou por responder a processo criminal, destacou a Ministra que a situação dos autos seria diferente, vez que os fatos ensejadores da ação penal, segundo o juízo discricionário do examinador, configurariam hipótese de exclusão do candidato, conforme disposição expressa do edital ${ }^{201}$.

A Turma, por unanimidade, negou provimento ao recurso ordinário.

7.2.20. Recurso em MS nº 39.186 - 2a . Turma - Relator: Herman Benjamin. Julgamento: $21 / 2 / 2013$

A inclusão deste acórdão demonstra que o entendimento do Superior Tribunal de Justiça acerca do controle dos atos discricionários pelo Judiciário encontra-se ainda apresentando divergências. Neste acórdão julgado em 21/2/2013, o Ministro Herman Benjamin assentou que o Judiciário deve analisar apenas a legalidade do ato e não imiscuir-se no mérito.

\footnotetext{
201 item 243 do edital, inserido no capítulo das disposições finais, contém a seguinte redação: Se a qualquer tempo for constatado, por meio eletrônico, estatístico, visual, grafológico ou de investigação policial, ter o candidato se utilizado de processos ilícitos, serão considerados nulos de pleno direito a sua inscrição, os resultados de suas provas e todos os atos decorrentes.
} 
Cuida-se de recurso em mandado de segurança impetrado pelos recorrentes, que foram expulsos da corporação, em decorrência de procedimento administrativo com a finalidade de apurar transgressões disciplinares praticadas pelos policiais militares, consistentes nos crimes de concussão e porte ilegal de armas de fogo.

Os recorrentes alegaram que a punição feriu o princípio da proporcionalidade e defenderam a suspensão dos efeitos do ato administrativo por ilegalidade e abuso de poder da autoridade coatora.

Assentou o Ministro que as garantias constitucionais foram observadas, não tendo sido verificada, no trâmite do processo disciplinar, de qualquer ofensa aos princípios do contraditório, do devido processo legal e da ampla defesa. Arrematou o Ministro, afirmando que "não cabe ao Judiciário imiscuir-se no mérito do ato administrativo, circunscrevendo-se seu exame, apenas, aos aspectos da legalidade do ato".

Citou o Ministro dois acórdãos do STJ, no mesmo sentido de seu entendimento, de que o Judiciário deve ater-se à regularidade do procedimento no exame dos atos administrativos discricionários: MS 6853/DF, 3. a Seção, Rel. Min. HAMILTON CARVALHIDO, DJ de 02/02/2004). "No que diz respeito ao controle jurisdicional do processo administrativo disciplinar, a jurisprudência desta Corte é firme no sentido de que compete ao Poder Judiciário apreciar a regularidade do procedimento, à luz dos princípios do contraditório, da ampla defesa e do devido processo legal, sem, contudo, adentrar no mérito administrativo"; e MS 8780/DF, 3. ' Seção, Rel. Min. GILSON DIPP, DJ de 28/10/2003 "Em relação ao controle jurisdicional do processo administrativo, a atuação do Poder Judiciário circunscreve-se ao campo da regularidade do procedimento, bem como à legalidade do ato demissionário, sendo-lhe defesa qualquer incursão no mérito administrativo, a fim de aferir o grau de conveniência e oportunidade”. Ambos os acórdãos foram objeto de análise neste trabalho

A Segunda Turma, por unanimidade, negou provimento ao recurso ordinário. 
7.2.21. AgRg no Recurso em MS no. 38.072/ PE, $2^{\mathrm{a}}$. Turma - Relator: Herman Benjamin. Julgamento: 28.5.2013

Neste acórdão, julgado em 28/5/2013, que tratou também de caso de servidor público militar excluído das fileiras da corporação com base em processo disciplinar, o Ministro manteve o seu entendimento de que "não cabe ao Judiciário imiscuir-se no mérito do ato administrativo, circunscrevendo-se seu exame apenas aos aspectos da legalidade do ato".

O Ministro negou provimento ao agravo regimental, no que foi seguido pelos demais Ministros da Segunda Turma.

7.2.22. AgRg no Recurso Especial n ${ }^{\circ} \cdot 1.087 .443 / \mathrm{SC}, 5^{\mathrm{a}}$. Turma- Relator: Marco Aurélio Bellizze. Julgamento: 04/06/2013

Este acórdão, relatado pelo Ministro Marco Aurélio Bellizze, finaliza os julgados escolhidos para análise. Nele, o Ministro assenta que, em regra, não cabe ao Judiciário examinar o mérito do ato administrativo. Posicionamento que, como se viu, não está solitário.

Trata-se, na origem, de ação proposta por servidor público federal, professor universitário, que teve seu pedido de licença para tratar de interesses particulares negados pela universidade.

O agravo regimental foi proposto pela Universidade Federal de Santa Catarina UFSC, em face de decisão assim ementada:

RECURSO ESPECIAL. ADMINISTRATIVO. SERVIDOR PÚBLICO FEDERAL. PROFESSOR UNIVERSITÁRIO. LICENÇA PARA TRATAR DE INTERESSE PARTICULAR. ATO DISCRICIONÁRIO DA ADMINISTRAÇÃO. REVISÃO PELO PODER JUDICIÁRIO. POSSIBILIDADE. MANIFESTA ILEGALIDADE. MOTIVAÇÃO INIDÔNEA. Recurso especial ao qual se nega seguimento.

Assentou o Ministro Marco Aurélio Bellizze que, não seria cabível ao Judiciário examinar o mérito do ato administrativo discricionário, em cuja espécie se enquadra o ato que aprecia pedido de licença de servidor para tratar de assunto particular; 
entretanto, "não se pode excluir do magistrado a faculdade de análise dos motivos e da finalidade do ato sempre que verificado abuso por parte do administrador".

O Ministro assentou que o motivo declinado para a não concessão da licença, mostrou-se inidôneo, vez que se baseou na imprescindibilidade da presença do professor. Assim, “diante de manifesta ilegalidade, não há falar em invasão do Poder Judiciário na esfera Administrativa, pois é de sua alçada o controle de qualquer ato abusivo, não se podendo admitir a permanência de comportamentos administrativos ilegais sob o pretexto de estarem acobertados pela discricionariedade administrativa".

Sublinhou, então, o Relator que, diante da motivação deficiente para o indeferimento da licença requerida e não havendo prejuízo ao interesse público, cabível a manutenção do acórdão impugnado.

A Turma negou provimento ao agravo regimental nos termos do voto do Relator. 


\section{Tribunal de Justiça de São Paulo}

Os acórdãos selecionados foram dispostos em ordem de data, do mais antigo para o mais recente e neles é possível verificar também a divergência de entendimento entre os acórdãos e, até mesmo, entre os próprios Desembargadores.

Já nos idos de 1948 é possível identificar essa divergência. No caso do Julgado relativo à apelação cível $\mathrm{n}^{\circ}$. 36.482, de 27/5/1948, relatado pelo Des. Meireles dos Santos, há divergência de entendimento entre ele e o Des. Juarez Bezerra, voto vencido.

Meireles dos Santos partilha do entendimento de que ao poder judiciário não compete aquilatar a justiça ou a injustiça do ato do executivo. Do contrário, seria invasão de atribuições e ofensa a prerrogativas do outro poder"; por sua vez, Juarez Bezerra entende que, na demissão de funcionário, o Poder Judiciário pode adentrar no mérito do ato não estando adstrito a somente apreciar o aspecto formal do ato e a competência da autoridade que o praticou.

\subsection{Acórdãos selecionados do Tribunal de Justiça de São Paulo}

8.2.1. Apelaçao Cível no .36 .482 - Relator: Meireles dos Santos. Julgamento: 27/5/1948

Trata-se de ação ordinária proposta pela apelada para obter a decretação de invalidade do ato do Governo do Estado que a demitiu do cargo de escriturária da Diretoria do Serviço de Trânsito, porque, sendo funcionária com mais de dez anos de serviço, tinha direito à estabilidade.

O Relator assentou, em seu voto, que, "ao poder judiciário não compete aquilatar a justiça ou a injustiça do ato do executivo. Do contrário, seria invasão de atribuições e ofensa a prerrogativas do outro poder".

Para ele, por mais injusta que possa ser a exoneração não cabe ao poder judiciário rever o processo e cancelar o ato do executivo, sobrepondo-se às suas atribuições. 
Decidiu que a sentença não poderia subsistir, dando provimento à apelação.

O Desembargador Juarez Bezerra, vencido na votação, citando a Lei nº . 221, de 20/11/1894, entendeu que a demissão de funcionário público estável não é faculdade ou poder discricionário, por isso que dependente de inquérito. Caberia assim, ao Poder Judiciário rever a decisão administrativa no seu conteúdo, no seu merecimento, abstendo-se apenas de apreciar a sua conveniência ou oportunidade, como seja a de mudança de serviço.

Sublinhou Juarez Bezerra que, na demissão de funcionário, o Poder Judiciário pode adentrar no mérito do ato, se foram respeitados os direitos de estabilidade. Não estando adstrito a somente apreciar o aspecto formal do ato e a competência da autoridade que o praticou.

Assentou ainda quanto à alegação de jurisprudência pacifica do Colendo Supremo Tribunal Federal em não admitir que o Judiciário aprecie o mérito: na demissão de funcionário público estável, citou a decisão no julgamento dos embargos na apelação cível n. 7.307, (também analisada nesta pesquisa), afirmando que a maioria dos julgadores emitiu opinião contrária, admitindo que o Judiciário reexaminasse a prova do inquérito administrativo contrapondo a prova produzida em juízo.

Entendeu manifesta a injustiça da demissão da autora, negando provimento à apelação.

Por maioria foi dado provimento à apelação da Fazenda do Estado.

Neste julgado de 1948 já se pode notar a divergência no entendimento dos desembargadores. A questão relativa ao mérito do ato permanecia como infensa ao controle do Judiciário; se bem que o Desembargador Juarez Bezerra entendeu como injusta a demissão da funcionária.

8.2.2. Apelação Cível n ${ }^{\circ} .46 .926$ - 5 . Câmara Civil - Relator: Joaquim de Silos Cintra. Julgamento: 24/3/1950 
Conforme se depreende pela leitura do acórdão, o apelado fora reformado com base em exame médico a que foi submetido perante a competente Junta Militar.

Consta que o autor teria requerido a nulidade do ato que o reformou, vez que o motivo do ato se deu "com base exclusiva na parcialidade, na injustiça e na ineficácia do laudo de exame a que fora submetido perante a competente Junta Militar". No entanto, sublinhou o Desembargador que escaparia "ao Judiciário o poder de examinar essa parcialidade, essa injustiça e essa ineficácia". "Em tal assunto a administração age discricionariamente".

Assentou ainda o Desembargador que mesmo que se examinem os motivos determinantes do ato, dentre os quais ressalta o exame médico pela Junta Militar, tem-se que não ficou demonstrado nos autos a imprestabilidade desse exame.

Asseverou também o Desembargador Silos Cintra que a doutrina e a jurisprudência mais reputadas em nosso direito entende que, ao Judiciário cabe apreciar o ato administrativo, apenas sob o aspecto de sua legitimidade. "Não se admite a anulação do ato pelo que os italianos chamam de "vizio di merito"”.

Ao finalizar seu voto afirmou que ao "Poder Judiciário não é dado, porém, reparar os erros e as injustiças da Administração. Cabe-lhe, apenas, lamentar a sua ocorrência ou punir os seus autores pelos crimes que hajam cometido, Neste sentido é, ainda, a lição sempre sábia de Costa Manso”.

Por votação unânime foi dado provimento ao recurso ex-officio para julgar improcedente a ação, condenando o autor nas custas.

8.2.3. Agravo de Instrumento $n^{\circ}$. 383.947.5/4 - Comarca de Pitangueiras, $3^{\text {a }}$. Câmara de Direito Público - Relator: Magalhães Coelho. Julgamento: 22/2/2005

Cuida-se de agravo de instrumento interposto pela Fazenda do Estado de São Paulo em ação civil pública movida pelo Ministério Público, insurgindo-se contra o despacho monocrático que deferiu a medida liminar que impôs a obrigação de remover da Cadeia Pública de Pitangueiras os atuais e futuros condenados definitivos ou presos provisórios. 
Magalhães Coelho iniciou seu voto afirmando que o despacho agravado não merecia censura, já que "a situação da Cadeia Pública de Pitangueiras é absolutamente alarmante, seja pela absoluta falta de estrutura, seja por absurda lotação em clara, evidente e insofismável violação da Lei de Execuções Penais, da Constituição Federal e do princípio da dignidade humana que é o substrato de toda ordem jurídica”.

Foi consignado pelo Relator não se tratar de matéria afeta à discricionariedade do Poder Executivo, vez que não haveria discricionariedade para o cumprimento da lei. Ao trazer a noção de discricionariedade, "margem de liberdade que a lei e a Constituição Federal conferem ao administrador público para consagrar, na hipótese colocada ao seu julgamento, a melhor solução que atenda ao interesse público", afirmou que mesmo a atividade administrativa discricionária sofre balizamento de lei, da Constituição Federal e dos seus princípios.

Sublinha seu posicionamento assentando que não se trata de intromissão do Poder Judiciário na seara do Poder Executivo, mas em cumprimento da lei. Para Magalhães Coelho, “o Poder Judiciário cumpre, aqui, sua missão constitucional de controle jurisdicional da Administração Pública".

Em votação unânime foi negado provimento ao recurso.

Pelo que se extrai do voto do Desembargador Magalhães Coelho, o Judiciário limitou-se a controlar a legalidade do ato, não houve nem mesmo menção à possibilidade de controle do mérito.

8.2.4. Apelação Cível nº. 395.016.5/9-00 - Americana, 6 ${ }^{\text {a }}$. Câmara de Direito Público Relator: Leme de Campos. Julgamento: 7/11/2005

Cuida-se de ação de obrigação de fazer proposta por munícipe de Americana, em face do Município e Rio Branco Esporte Clube objetivando fossem tomadas providências no sentido de se evitar que a residência do requerente continuasse sendo atingida pelas bolas provenientes do estádio municipal, com a realização de obras necessárias com elevação do muro que cerca o clube de futebol, ou, que se instalasse tela de proteção para que a residência do requerente fosse protegida pelas bolas 
perdidas, com fixação de prazo razoável sob pena de multa diária. A sentença julgou improcedente a ação.

O Relator considerou, assim como o juiz de $1^{\circ}$. grau, tratar-se de ato discricionário da administração, que só seria viabilizada de acordo com a conveniência e oportunidade do administrador, e que não caberia ao Judiciário obrigar a municipalidade a executa-la, sob pena de ferir princípios constitucionais básicos da tripartição dos poderes e do federalismo. Assentou também a impossibilidade do Poder Judiciário substituir a discricionariedade do administrador pela do juiz.

Por votação unânime foi negado provimento ao recurso.

A escolha deste julgado se deu visando mostrar quase que certa descaracterização no sentido de ato discricionário, já que não se insere na discrição da Administração a possibilidade de causar dano ao patrimônio de quem quer que seja.

8.2.5. Apelação nº 533.398.5/5-00, $3^{\text {a }}$. Câmara de Direito Público - Relator: Marrey Uint Julgamento: 5/8/2008

Este acórdão trata de ação movida contra a Fazenda do Estado tendente a obrigála ao custeio do tratamento do filho da autora, portador de autismo severo. A Sentença julgou procedente o pedido inicial condenando o Estado a prestar ao filho autista da autora o tratamento especializado a ele necessário, e ainda as mensalidades da internação do autor desde março de 2000 até outubro de 2001 (data do primeiro depósito judicial), mais custas e honorários em $\mathrm{R} \$ 2.000,00$. A Fazenda do Estado de São Paulo, no recurso, aduziu a ilegitimidade de parte e a ingerência do poder judiciário a ferir a independência dos poderes, insurgindo-se, ainda, contra a fixação da multa diária que lhe fora imposta.

Os destaques do voto terão como base, apenas, os aspectos que interessam à pesquisa.

Para Marrey Uint não há que se falar em violação ao princípio da independência dos poderes, já que o Poder Judiciário apenas exercita a sua missão constitucional, nem com relação a discricionariedade administrativa. $\mathrm{O}$ direito à vida é garantia fundamental 
e não apenas um jogo de palavras, uma retórica. É dever do Estado garanti-la assegurando o acesso à saúde pública.

A discricionariedade concedida ao Administrador não o dispensa do estrito respeito à Constituição Federal. Não haveria, "no poder discricionário, uma vontade absolutamente livre do administrador, nem a pretensa imunidade a seu controle". Assim, implementar ou deixar de implementar políticas de saúde pública não seria uma questão ligada à subjetividade do administrador.

Assenta Marrey Uint em relação à alegada impossibilidade orçamentária que "não tem o menor substrato e assiste ao cidadão o direito de exigir do estado a implementação de tais direitos. Que se proceda a uma gestão eficiente do Estado, qual o comando Constitucional determina".

O voto do Revisor, Magalhães Coelho, também foi no mesmo sentido. Para ele, a sentença não ofendeu a discricionariedade administrativa, nem a independência dos Poderes; vez que não há que se falar em violação ao princípio da independência dos Poderes quando o Poder Judiciário atua no exercício de sua missão constitucional.

De acordo com o Revisor, é necessário que esses direitos venham a ser respeitados e implementados pelo Estado, destinatário do comando constitucional. "Se não o fez. Se pretexta a retórica, argumentos destituídos de significação, como a impossibilidade orçamentária, assiste ao cidadão o direito de exigir do Estado a implementação de tais direitos".

Assenta que não houve qualquer ofensa à discricionariedade administrativa e sublinha que

(..) a existência de uma opção discricionária não torna imune a função administrativa ao controle jurisdicional, uma vez que sua atribuição ao administrador público não é um 'cheque em branco' que possa ser preenchido com qualquer conteúdo, ainda que ofensivo aos vetores axiológicos do sistema normativo e, notadamente, da Constituição Federal.

O exercício de faculdades discricionárias não dispensa a Administração Pública de respeito à Constituição Federal. Destaca ele 
que, "não há, portanto, no poder discricionário uma vontade absolutamente livre do administrador, nem a pretensa imunidade a seu controle.

Conclui, então, que a atuação do administrador em relação à implementação de políticas pública pode e deve ser controlada pelo Poder Judiciário que é, "também, um Poder político no sentido de que comprometido com o bem comum - e com a implementação dos valores que formam a base do Estado Democrático e Social de Direito albergado na Constituição Federal”.

Por unanimidade foi negado provimento ao recurso.

Este acórdão mostra uma nítida tendência do Tribunal, ao menos da $3^{\text {a }}$. Câmara, em considerar amplo o controle do Judiciário quando se trata da implementação de políticas públicas que se relacionem à saúde.

8.2.6. Apelação Cível nº 865.259.5/8-00 - Ribeirão Preto, 6a . Câmara de Direito Público Relator: José Habice - Julgamento: 14/12/2009

Neste acórdão o ato administrativo discricionário fora praticado pelo Poder Legislativo e não pela Administração.

Trata-se de ação popular ajuizada contra a Fazenda Pública do município de Ribeirão Preto, Mesa da Câmara Municipal, Silvio Geraldo Martins, Mário Sampaio, Darcy Vera e Sebastião Souza. O autor da ação popular entende que houve ofensas aos princípios da Administração Pública e irregularidades no processo licitatório na compra de 10 veículos 0 km para a Câmara Municipal de Ribeirão Preto. Requereu, ainda, com o pedido de liminar, a proibição da compra dos automóveis de luxo.

A sentença julgou improcedente o pedido constante na inicial, considerando a inexistência de vício no procedimento licitatório, condenando o autor, nos termos do artigo 13 da Lei 4.717/65, ao pagamento de indenização por litigância de má-fé. Inconformado, apela o autor. 
Considerou o Relator que o pedido refere-se a aspecto discricionário da atuação da Administração Pública e uma vez não observadas quaisquer irregularidades no procedimento licitatório, seria defeso ao judiciário a apreciação do mérito da questão.

Em relação ao controle das políticas públicas, assentou o Relator que, embora a Municipalidade de Ribeirão Preto estivesse, à época, com problemas em diversas áreas, como saúde e educação não poderia o Judiciário controlar o mérito dessas políticas públicas, devendo o controle restringir-se à legalidade e da moralidade dos atos administrativos. Para o Relator, então,

O controle do mérito das políticas públicas, sejam elas oriundas do Legislativo ou do Executivo, deve ser realizado pelos próprios cidadãos, por meio de debates com seus representantes e, principalmente, no momento da eleição. Caso os cidadãos não estejam satisfeitos com os rumos e prioridades escolhidos pelos seus governantes, cabe a eles expressar sua insatisfação por meio das umas e de outros mecanismos de participação popular, não reelegendo àqueles que os decepcionaram. Ao Judiciário, bem como aos demais órgãos de controle administrativo, cabe somente, conforme já mencionado supra, apenas a verificação da legalidade e moralidade dos atos praticados com dinheiro público.

Foi negado provimento ao recurso, por unanimidade.

Verifica-se uma divergência de entendimento entre este julgado e o julgado anterior, relatado pelo desembargador Marrey Uint, vez que no acórdão $\mathrm{n}^{\circ}$. 533.398.5/500, da $3^{\mathrm{a}}$. Câmara de Direito Público o entendimento era por um controle amplo do Judiciário no caso da saúde, enquanto neste, o Desembargador José Habice assentou por um controle apenas de legalidade e da moralidade administrativa.

8.2.7. Apelação Cível nº. 588.906.5/2-00 - Santo André, 9ª . Câmara de Direito Público Relator: Oswaldo Luiz Palu. Julgamento: 9/6/2010

Cuida-se de ação civil pública proposta pelo Ministério Público do Estado de São Paulo, que teve como objeto a dispensa de licitação para a contratação da empresa Rotedali - Serviços e Limpeza Urbana Ltda, na execução de serviços e operação de um aterro sanitário no Município de Santo André. A dispensa do certame foi autorizada pelo então Secretário de Serviços Municipais Klinger Luiz de Oliveira Souza, cujo objetivo teria sido o de favorecer seu amigo Ronan Maria Pinto, sócio da referida 
pessoa jurídica. A empresa ENTERPA ENGENHARIA LTDA, contratada em 21 de agosto de 1997, após regular licitação, estava prestando serviços no referido aterro sanitário, quando então o Departamento de Limpeza e Conservação Viária (órgão municipal vinculado à Secretaria de Serviços Municipais), instaurou processo para a contratação emergencial de empresa para operação do aterro referido.

Consultadas três interessadas teria apresentado a melhor proposta a empresa Rotedali - serviços e limpeza urbana Ltda, sendo contratada mediante dispensa de licitação (art. 24, IV, da Lei n. ${ }^{\circ}$ 8.666/93) . O valor do contrato foi de R\$1.167.856,20. O Tribunal de Contas do Estado julgou irregular a dispensa da licitação e o contrato firmado.

O Ministério Público requereu a condenação de todos, com fundamento no artigo 10, VIII, da Lei $\mathrm{n}^{\circ}$. 8.429/92.

A despeito de toda a discussão travada, o aspecto que interessa à pesquisa diz respeito à existência ou não de poderes discricionários por parte do agente público.

De acordo com o Relator, o agente público, Klinger Luiz de Oliveira Souza, não possuía poderes discricionários para atuar como atuou. Cumpre, então, transcrever trecho do voto onde fica claro esse posicionamento do Relator:

(..)sobre a espécie há normas jurídicas bem claras. Quando tomasse uma decisão, no sentido da dispensa, no mínimo, deveria justificar a mesma. A Administração tem poderes para atuar discricionariamente acerca do índice que melhor atenda aos interesses do contrato que pretende fazer cumprir. Outra coisa é entender que pode o agente público agir livremente. Ao contrário, há balizas objetivas, dentro dos parâmetros do Direito Público, que são as reiteradas decisões das cortes de contas.

Assentou o Relator que a conduta do agente caracterizou desvio de finalidade, já que haveria sérios indícios da proximidade entre o secretário municipal e o sócio da empresa contratada, fatos esses que foram tornados públicos pela mídia. Ressaltou também a falta de motivação do ato, ao mencionar a ausência de justificação da dispensa

Foi, então, dado provimento ao recurso ministerial, por votação unânime, nos termos do voto do Relator. 
$\mathrm{O}$ aspecto que se destaca no controle do ato administrativo em questão é a aplicação da teoria do desvio de finalidade, já que a prática do ato tinha objetivo diverso que não o atendimento ao interesse público. Outro aspecto a se destacar diz respeito ao entendimento do desembargador, no que foi seguido por seus pares, no sentido da inclusão das decisões reiteradas das cortes de contas como parâmetro a ser também seguido pela Administração.

8.2.8. Apelação Cível nº 990.10.059277-7, 3ª . Câmara de Direito Público - Relator: Marrey Uint. Julgamento: 30/11/2010

Cuida-se, na origem, de ação que visava anular decisão do Tribunal de Contas do Estado que julgara irregular a dispensa de licitação para a contratação da empresa Cobra Tecnologia S/A, que fora contratada para desenvolver software visando reestruturar o sistema de cobrança e controle de ISSQN.

Não se pretende fazer uma análise da questão relativa à possibilidade da dispensa da licitação, mas, apenas, no que diz respeito ao entendimento do Relator e demais Desembargadores, quanto à possibilidade do controle judicial do ato administrativo.

A sentença julgou procedente a ação, anulado a decisão do Tribunal de Contas que considerara irregular a contratação da Empresa Cobra Tecnologia. A Fazenda recorreu alegando que não era possível a Prefeitura questionar as decisões do Tribunal de Contas, sob pena de violação do princípio da separação dos poderes.

O Relator, em seu voto, afirmou que o Poder Judiciário pode sim rever os atos administrativos e, inclusive, ir além da análise da mera regularidade do ato, já que, para aferir-se a regularidade e legalidade de um ato faz-se necessário examinar a sua motivação e se ela corresponde aos fatos existentes.

Asseverou também que:

(...) é costume se dizer que é vedado ao Poder Judiciário imiscuir-se no mérito do ato administrativo, mormente quando o mesmo encontrase dentro da razoabilidade. Ora, mas para tanto é necessário que se examine se o mesmo é razoável ou não. Assim, não basta que o ato seja formalmente legal, mas ele tem que atender a todos os princípios constitucionais e à legislação aplicável. 
A dispensa de licitação teria atendido aos parâmetros do art. 24, VIII, da Lei nº. 8.666/93, já que a empresa contratada, por ser subsidiária do Banco do Brasil, integraria a administração pública, além de estar o preço contratado, compatível com o praticado no mercado.

Foi, então, negado provimento ao recurso de apelação por unanimidade.

O Desembargador Marrey Uint neste acórdão mostra-se, mais uma vez, tendente a aceitar um controle mais elastecido dos atos administrativos, como já demonstrado no acórdão anteriormente analisado, também de sua lavra.

8.2.9. Apelação Cível no. 990.10.194745-5, 8ª . Câmara de Direito Público - Relator: Cristina Cotrofe. Julgamento: 1/12/2010

Este acórdão trata de mandado de segurança impetrado contra ato do Diretor de Pessoal da Divisão de Seleção e Alistamento da Polícia Militar visando à anulação de reprovação médica e consequente reprovação para o cargo de Soldado PM 2a . Classe, por ter sido considerado inapto em razão de possuir tatuagem no braço esquerdo.

A sentença julgou procedente a ação e concedeu a ordem para afastar a decisão de inaptidão ao cargo e assegurar ao impetrante o direito de participar das fases seguintes do aludido concurso. Inconformada, apelou a Fazenda do Estado buscando a inversão do julgado.

Ficou bem caracterizado no acórdão que o ato da Administração foi plenamente analisado pelo Judiciário, como se verifica do seguinte trecho extraído do julgado:

Pelo que se extrai dos documentos acostados aos autos, principalmente as fotografias de fls. 24/47, denota-se que tal tatuagem não ofende os critérios estabelecidos no edital porque não há nada que indique afronta à moral e aos bons costumes. Também não se trata de figura de grandes dimensões que cubra o braço em sua totalidade. Aliás, ao contrário do que afirma o ofício de fls. 70, não fica visível quando da utilização de uniforme de treinamento físico, como restou demonstrado de forma inequívoca pelas fotos de fls. 32, 33, 35 e 47. 
O posicionamento da Desembargadora acerca do controle dos atos administrativos pelo Poder Judiciário ficou bastante claro em sua afirmação de que "a apreciação dos atos administrativos pelo Poder Judiciário é admitida em qualquer hipótese, de modo que inexiste qualquer óbice à anulação determinada pelo MM. Juízo a quo". Foi também destacado por ela a súmula 473 do STF, segundo a qual, "a Administração pode anular seus próprios atos, quando eivados de vícios que os tornem ilegais, porque deles não se originam direitos; ou revogá-los, por motivo de conveniência ou oportunidade, respeitados os direitos adquiridos, e ressalvada, em todos os casos, a apreciação judicial”.

Por unanimidade, foi negado provimento aos recursos.

Neste acórdão a Desembargadora Cristina Cotrofe deixou claro o seu entendimento acerca da apreciação dos atos administrativos, sejam eles vinculados ou discricionários, no sentido de que, em qualquer hipótese, é possível o controle pleno pelo Judiciário.

8.2.10. Apelação Cível nº 990.10.489240-6 - Jaú 3 ${ }^{\text {a }}$. Câmara de Direito Público - Relator: Magalhães Coelho. Julgamento: 8/2/2011

Trata-se de recurso de apelação interposto pela Prefeitura Municipal de Jaú, em ação civil pública que lhe moveu o Ministério Público, objetivando a implantação de galerias de águas pluviais em vários bairros e loteamentos da Municipalidade. Julgada parcialmente procedente na origem, foi assinalado o prazo de 06 (seis) meses para a apresentação do cronograma das obras e seu início em 01 (um) ano, sob pena de imposição de multa diária no valor de $\mathrm{R} \$ 1.000,00$ (hum mil reais).

A análise do julgado restringir-se-á à análise da questão relativa ao controle judicial do "não agir" da administração.

De acordo com o que consta do voto do Relator, seria incontroversa a necessidade da realização das pretendidas obras públicas, atestadas, inclusive, pelas vistorias procedidas pela própria Municipalidade e pela Associação de Engenheiros e Arquitetos de Jaú. A Secretaria de Obras e Planejamento da Municipalidade posicionou- 
se pela necessidade e pela viabilidade técnica das obras de galerias de águas pluviais, de modo a evitar, senão, a minorar os efeitos das inundações e enchentes no Município. Considerou, então, o Relator, que a construção das galerias pluviais consistiria em um dever-mínimo para a Administração, já que haveria uma responsabilidade solidária do município quanto a regularização dos loteamentos, vez que é seu dever impedir toda atividade nociva a prejudicar o espaço urbano.

Quanto à possibilidade do controle judicial, asseverou o Relator que a existência da discricionariedade não torna a função administrativa imune ao controle jurisdicional, vez que essa possibilidade não e uma cheque em branco, que pode ser preenchido com qualquer conteúdo, ainda que ofensivo aos vetores axiológicos do sistema normativo e, notadamente, a Constituição Federal. Não haveria, portanto, no poder discricionário uma vontade absolutamente livre do administrador, nem a pretensa imunidade a seu controle.

Assim, implementar ou deixar de implementar políticas urbanísticas não é uma questão afeta à subjetividade do administrador; ainda que se reconheçam graus de liberdade em suas opções, não poderia o administrador furtar-se a cumprir e concretizar políticas públicas erigidas pela Constituição Federal, como na hipótese da saúde pública, em direito subjetivo individual e coletivo da cidadania.

Para Magalhães Coelho, essa postura do administrador público "pode e deve ser controlada pelo Poder Judiciário que é, também, um Poder político no sentido de que comprometido com o bem comum - e com a implementação dos valores que formam a base do Estado Democrático e Social de Direito albergado na Constituição Federal”.

O desenvolvimento de políticas urbanísticas e de proteção à saúde e vida dos munícipes não é, segundo o Desembargador, questão afeta à subjetividade do administrador. É notório que o Administrador tem espaços de liberdade, de discricionariedade, entretanto, não pode ele ignorar as diretrizes traçadas pela Constituição Federal.

Finalizando, cabe transcrever posicionamento do relator, externado em livro de sua autoria citado no acórdão analisado, acerca do controle da discricionariedade administrativa: 
O controle jurisdicional da discricionariedade administrativa não significa, em absoluto, como advertirá o próprio Enterría, na anulação ou no aniquilamento dos poderes administrativos. Não é disso de que se trata ou que se pretende. Cuida-se apenas de verificar se, na sua atuação concretizadora da finalidade da lei, a administração pública está não só respeitando, como ainda implementando os vetores axiológicos do ordenamento jurídico. O que não se pode pretender, à evidência, é que ao exercer faculdades discricionárias, possa ela se colocar ao abrigo do controle da principiologia constitucional, que deve ser levada a efeito, até suas últimas conseqüências, pelo Poder Judiciário que, ao agir assim, estará apenas e tão-somente cumprindo sua missão constitucional. Nem se pretenda que, ao fazê-lo, estará a invadindo o "mérito" do ato administrativo. Fazer valer os vetores constitucionais é tarefa imperiosa do Poder Judiciário que não pode se acovardar a pretexto de invasão de competência de outro poder. Evidentemente, haverá sempre no ato administrativo discricionário uma esfera última de liberdade do administrador para fazer sua opção diante das circunstâncias concretas da hipótese, diante de certas singularidades, em que ao Poder Judiciário será vedado imiscuir-se. Aí e tão-somente aí, radicará a liberdade do administrador que o Juiz evidentemente não poderá substituir, porque é a tarefa mesma, por excelência, do poder político. (Controle Jurisdicional da Administração Pública, pg. 54- Editora Saraiva, 1a edição - São Paulo, 2002).

Negou-se provimento ao recurso, por votação unânime.

Neste Julgado, o Desembargador Magalhães Coelho, externa seu pensamento acerca do controle dos atos discricionários pelo Judiciário, da mesma forma coerente como já havia feito quando da análise da apelação $\mathrm{n}^{\circ}$. 533.398.5/5-00, ao asseverar que o judiciário pode e deve controlar a postura do administrador público.

\subsubsection{Apelação Cível nº 994.08.110413-3, 2ª . Câmara de Direito Público - Relator: Samuel} Junior - Julgamento: 19/4/2011 
Trata-se de apelação interposta em face de sentença que julgou improcedente ação ordinária proposta contra a Prefeitura Municipal de Catanduva, objetivando a anulação de dispensa, com a consequente reintegração ao cargo de agente fiscal de tributos.

O conhecimento do motivo que levou à edição do ato administrativo é importante para a compreensão do voto do Desembargador. Têm-se então neste caso que,

o procedimento administrativo disciplinar foi instaurado para apurar a paralisação do requerimento de imunidade tributária da Fundação Padre Albino por 378 dias. A Comissão Processante considerou que o funcionário foi desidioso no desempenho de suas funções, enquadrando-se no inciso XVI do art. 286 da Lei Complementar $n^{\circ}$ 31/96. A sua desídia consistiu em "não ter efetuado a respectiva 'notificação' ao contribuinte, portanto, não iniciou os trabalhos fiscais dentro do prazo legal, e não solicitou a sua superior hierárquica que o presente processo fosse redistribuído a outro agente fiscal de tributos" quando entrou em licença saúde por seis meses.

O processo administrativo assegurou ao apelante as garantias constitucionais do contraditório e da ampla defesa.

No entendimento do Desembargador Samuel Junior o Poder Judiciário não pode entrar no mérito do ato administrativo e, dessa forma, não é possível sustentar a procedência do pedido, no entendimento de que as justificativas apresentadas não foram suficientes para dar base ao decreto expulsório.

8.2.12. Apelação Cível nº 9060065-90.2009.8.26.0000, São Paulo - 8 ${ }^{\text {a }}$. Câmara de Direito Privado - Relator: Carvalho Viana. Julgamento: 17/10/2012

Trata-se de mandado de segurança impetrado contra ato do major da polícia militar e chefe interino da polícia militar do Estado de São Paulo, que desclassificou o impetrante do concurso público para ingresso na carreira de soldado. O próprio impetrante, ao preencher o formulário de investigação social informou que 
experimentara maconha, quando tinha 14 anos, durante um jogo de futebol e que nunca mais usou.

Para o desembargador, faltou razoabilidade no ato de exclusão, já que houve um único fato desabonador, o que não revelaria "perfil incompatível" com a profissão, segundo o edital. A desclassificação fere o princípio da razoabilidade, mostrando-se desproporcional o ato da administração face ao fato apontado como desabonador.

Assentou também que a previsão contida no edital, segundo a qual estaria desclassificado o candidato que fez ou faz uso de drogas ilícitas, não se aplicaria ao impetrante, já que a expressão "fazer uso" sugeriria, segundo o desembargador, uma conduta constante e não o simples ato de adolescente que teve a curiosidade de experimentar o entorpecente.

De acordo com o entendimento do desembargador, a declaração judicial considerando o impetrante apto na fase de investigação social não afronta o princípio da separação de poderes. Uma vez reconhecida a ilegalidade, por violar o princípio da razoabilidade, cabe ao Judiciário fazer prevalecer o Direito, atuando no controle da legalidade.

A Oitava Câmara negou provimento ao recurso, por votação unânime.

Neste acórdão, o Desembargador Carvalho Viana entendeu caber o controle da legalidade do ato administrativo discricionário, considerando ter havido violação ao princípio da razoabilidade no ato de exclusão do impetrante, na fase de investigação social, em concurso público para o cargo de policial militar.

8.2.13. Reexame Necessário $\mathrm{n}^{\mathrm{o}}$. 0000700-04.2011.8.26.0159, 11ª . Câmara de Direito Público - Relator: Ricardo Dipp. Julgamento: 22/1/2013

Cuida-se de mandado de segurança impetrado por permissionários do serviço de taxi no Município de Cunha, contra ato do Prefeito municipal que cassou a permissão, por força de noticiado ilícito administrativo consistente na falta de utilização, pelos impetrantes, do correspondente ponto de serviço de taxi. A sentença de origem concedeu a ordem, salvo quanto a um dos litisconsortes. 
O Relator, Desembargador Gilson Dipp, no início de seu voto assenta que a permissão, a exemplo dos demais atos administrativos discricionários, não poderia, em princípio, ser verificada pelo Poder Judiciário quanto a seu mérito, ou seja, quanto à conveniência e oportunidade de seu objeto, matéria essa que seria própria da Administração Pública e que, muito limitada e excepcionalmente, poderia estar sujeita ao controle do Poder jurisdicional que, entretanto, "não é uma espécie de Supra- Poder do Estado".

Para ele, a possibilidade do controle jurisdicional de decisões administrativas suscetíveis de ameaçar ou malferir direitos, conforme inc. XXXV do art. $5^{\circ}$ da Constituição Federal de 1988, limita-se "na esfera do mérito administrativo, à aferição dos aspectos vinculados da decisão objeto e, com relação ao âmbito discricionário, ao exame dos motivos e fins do ato administrativo".

Consigna que a motivação expressa, na esfera dos atos discricionários, vincula o agente público e, "dessa maneira, a exigível congruência do ato administrativo impõe a consonância entre a realidade subjacente, o conteúdo do ato e sua causa, tal que fins e motivos estejam em conformidade lógica, sem que se admita, além disso, no campo dos atos administrativos discricionários, o exercício de uma discricionariedade substituinte pelo Poder Judiciário".

Destacou também que a permissão fora cassada por apontado ilícito administrativo (abandono de atividade), sem que tenha sido concedido o direito de ampla defesa e de contraditório, o que leva à manutenção da sentença.

Foi, então, negado provimento à remessa obrigatória interposta nos autos.

Neste caso, o voto do desembargador Ricardo Dip destacou a necessidade da motivação do ato administrativo, de modo que fins e motivos estejam sempre em conformidade lógica; bem como da obrigatoriedade da observância dos princípios constitucionais da ampla defesa e do contraditório.

8.2.14. Apelação Cível no ${ }^{\circ}$ 0041683-09.2010.8.26.0053, $8^{\mathrm{a}}$. Câmara de Direito Público -= Relatora: Maria Cristina Cotrofe. Julgamento: 30/1/2013 
Cuida-se, na origem, de ação ordinária ajuizada em face da Fazenda Pública, por ter sido o autor reprovado em concurso público na fase de investigação social, em razão do uso de droga ilícita (maconha) na adolescência e por ser inadimplente com seus compromissos financeiros.

A sentença julgou improcedente o pedido, condenado o autor em honorários e custas processuais. Irresignado recorreu buscando a inversão do julgado, aduzindo que não teria havido um procedimento administrativo para a apuração dos fatos e que os motivos que levaram à sua exoneração seriam inconsistentes e desprovidos de provas concretas.

A desembargadora assentou que a apreciação dos atos administrativos pelo Poder Judiciário é admitida em qualquer hipótese, de modo que inexiste óbice para que se analisem os motivos da reprovação contra os quais se insurgiu o apelante. Asseverou também que "a liberdade da Administração para estabelecer as bases de seus certames deve ser pautada pela razoabilidade" e, uma vez não observado este princípio, "cabe ao Judiciário analisar e reprimir ilegalidades cometidas pelo administrador, não havendo que se falar em intromissão na discricionariedade do mérito do ato".

Considerou a desembargadora que a reprovação fora arbitrária, caracterizada por uma postura da administração "que contraria os princípios que norteiam os concursos públicos, sobretudo a impessoalidade e a razoabilidade", sendo inegável o excesso praticado pela autoridade ao excluir o candidato.

Foi dado provimento ao recurso, por votação unânime.

Neste acórdão ficou claro o entendimento da desembargadora, no sentido de que os atos administrativos, inclusive os discricionários sujeitam-se ao amplo controle jurisdicional, nos termos da súmula 473 do STF, citada por ela citada.

A apelação cível no . 9060065-90.2009.8.26.0000, cuja relatoria ficou a cargo do Desembargador Carvalho Viana, analisou situação análoga à deste acórdão. Entendeu o Desembargador que teria havido ilegalidade por violação ao princípio da razoabilidade. No caso presente, a Desembargadora vai além ao considerar a violação da razoabilidade, assenta que a apreciação dos atos administrativos pelo Judiciário é admitida em qualquer hipótese, inexistindo óbice na análise quanto aos motivos da reprovação. 
8.2.15. Apelação $n^{\circ}$. 0034542-02.2011.8.26.0053, São Paulo - 8 a . Câmara de Direito Público

- Relator: Paulo Dimas Mascaretti. Julgamento: 8/5/2013.

Cuida-se de mandado de segurança impetrado contra ato do Diretor de Pessoal da Polícia Militar do Estado de São Paulo, que desclassificou o impetrante na fase de investigação social, em concurso que objetivava o ingresso no posto de soldado.

Segundo consta do voto, a autoridade coatora concluíra pela incompatibilidade do candidato para o exercício da função policial militar, apontando que o impetrante teria omitido, no Formulário de Investigação Social, que figurara como autor em ocorrência de ameaça e lesão corporal dolosa, bem como o envolvimento dos seus genitores em Boletim de Ocorrência da Polícia Civil de ameaça.

Para o desembargador, é possível entrever "que houve rigor excessivo na avaliação levada a efeito, carecendo de justificativa plausível o ato de exclusão do impetrante do certame"; mostrando-se evidente que a exclusão do concurso atentou contra os princípios da razoabilidade e da proporcionalidade.

Com as citações a seguir transcritas, utilizadas pelo Relator no acórdão, pode-se concluir que ele se filiava à corrente que entende não caber ao Judiciário a incursão no mérito do ato administrativo: citou Diomar Ackel Filho, "o que se veda é a perquirição da oportunidade ou conveniência da punição, ou de sua efetiva justiça. Isso é problema do administrador. Mas se a contemplação dos pressupostos que legitimam o ato, quer no aspecto formal, quer no material, revelar a possibilidade de dano ou justo receio dele, o mandado de segurança será cabível" ("Writs Constitucionais", 2a edição, Saraiva, São Paulo, 1991, p. 74/75) e Hely Lopes Meirelles, que nesse diapasão, anota "não há de confundir o mérito administrativo do ato, infenso à revisão judicial, com o exame de seus motivos determinantes, sempre passíveis de verificação em juízo.

Conclui o voto, assentando que é flagrante a ilegalidade da conduta administrativa, já que a motivação lançada para alicerçar o ato administrativo, contrasta com a realidade fática. Para ele, "no controle de legalidade incumbe ao Judiciário a verificação dos antecedentes de fato e sua congruência com as justificativas que determinaram a decisão administrativa, ou seja, o exame dos motivos que a ensejaram. 
A ausência de nexo entre a realidade demonstrada e os fundamentos jurídicos da atuação pública caracterizam o vício de ilegalidade e a consequente nulidade do ato administrativo". Para ele, toda disciplina punitiva deve subordinar-se ao princípio da proporcionalidade em sentido amplo, no qual se contém a razoabilidade, impondo-se então a equivalência entre a realidade fática e a cominação imposta no edital do concurso.

A Oitava Câmara deu provimento ao apelo, por unanimidade.

No mesmo sentido deste julgado, são os seguintes acórdãos: Apelação Cível $n^{\circ}$ 0041683-09.2010.8.26.0053, da relatoria da Desembargadora Maria Cristina Cotrofe e a Apelação Cível No 9060065-90.2009.8.26.0000, cuja relatoria ficou a cargo do Desembargador Carvalho Viana, ambos já analisados neste trabalho.

8.2.16. Apelação nº 0003687-74.2011.8.26.0268, Câmara Especial - Relator: Costabilè e Solimene. Julgamento: 15/4/2013

Cuida-se de ação civil pública julgada procedente na origem para condenar as Fazendas Municipal e Estadual, solidariamente, a disponibilizarem, no prazo de sessenta dias, programa oficial comunitário de auxílio, orientação e tratamento às crianças portadoras de dependência química, bem como vagas para internação de crianças e adolescentes para tratamento daquela patologia, de acordo com indicação médica, sob pena de multa diária arbitrada na ordem de quinhentos reais para cada menor não incluído.

A Municipalidade, além das preliminares de ilegitimidade passiva e falta de interesse processual, alegou também que a pretensão formulada na exordial implicaria em ingerência descabida em decisão puramente política, o que afetaria o orçamento público e demais programas de governo em andamento. Por fim, invocou a teoria da reserva do possível e o princípio da separação dos poderes.

A Fazenda do Estado de São Paulo também suscitou preliminar de ilegitimidade passiva, alegando que a responsabilidade seria exclusivamente do ente municipal. No mais, sustentou que as normas relativas ao direito à saúde seriam de natureza programática, cogitando de violação ao princípio da separação dos poderes, igualdade e 
predominância do interesse coletivo sobre o individual. Por fim, aduziu que a multa pecuniária teria sido arbitrada em patamar excessivo e requereu a ampliação do prazo para cumprimento da ordem judicial.

O Desembargador, em seu voto, afirmou que as pretensões deduzidas contra o poder público devem ser examinadas mediante a ponderação de bens, com base no critério da proporcionalidade. Assim, no que diz respeito à preservação da vida e da saúde, há de se afastar a incidência da "teoria da reserva do possível", por considerar que ambos são bens máximos e impossíveis de terem sua proteção postergada.

Quanto à questão da ofensa ao princípio da separação de poderes, o desembargador utilizou-se de diversos precedentes que, em casos de natureza semelhante, afastaram esse tipo de argumentação. De acordo com o RE nº 257.109 AgR/RS, Rel. Ministro Maurício Corrêa, julgado em 8/8/2000, DJ 7/12/2000

Finalizando o voto, o Relator afirmou que "a discricionariedade administrativa restou preservada no r. julgado monocrático, facultando-se, para cumprimento da decisão, a celebração de convênios com outros municípios que disponibilizem aqueles serviços, ou, ainda, com entidades civis sem fins lucrativos, assim como pela possibilidade de contratação de clínicas particulares".

Verifica-se, nos casos que envolvem "direito à saúde", como é o caso dos julgados exposto, que o Judiciário vem decidindo, via de regra, no sentido do atendimento ao pleito dos autores, seja no caso de ações individuais ou nas coletivas.

8.2.18. Apelação com revisão n ${ }^{\circ}$. 0004833-82.2011.8.26.0129, 4a . Câmara de Direito Público - Relatora: Ana Luiza Liarte. Julgamento: 24/6/2013

Cuida-se de ação ordinária proposta em face da Fazenda do Estado de São Paulo que, por conta da sindicância administrativa disciplinar, lhe teria aplicado penalidade de suspensão por cinco dias. A ação pretende a anulação da decisão, bem como a retirada da reprimenda da ficha funcional da autora.

O interesse por este julgado reside no fato de que a desembargadora, explicitamente, asseverou que cabe ao Judiciário o exame dos atos discricionários à luz dos princípios da razoabilidade e da proporcionalidade; muito embora admita, na 
sequência, que o fato de o Judiciário estar impedido de avaliar a conveniência e oportunidade dos atos administrativos, não significa que esteja completamente imune à apreciação judicial.

Segundo a desembargadora, os princípios da razoabilidade e da proporcionalidade possibilitam um controle mais efetivo da discricionariedade administrativa, a fim de evitar possíveis arbitrariedades, na atuação dos agentes estatais e, citando Celso Antonio Bandeira de Melo, aduziu que o princípio da razoabilidade é um desdobramento da legalidade.

Concluiu, afirmando que, "diante da possibilidade de controle do mérito administrativo, quanto à atividade baseada na avaliação do binômio conveniência/oportunidade, tem-se que, no caso sub judice, a penalidade imposta à autora não foi medida desproporcional".

Foi negado provimento ao recurso, por votação unânime.

8.2.19. Apelação Cível nº 0016363-83.2012.8.26.0053, 5ª . Câmara de Direito Público Relatora: Maria Paula Tavares. Julgamento: 29/7/2013

Cuida-se de Mandado de Segurança impetrado contra ato do subprefeito da subprefeitura da Moóca, que revogou o Termo de Permissão de Uso, que fora concedido à impetrante para a realização de comércio de produto não alimentício na Rua Maria Marcolina, 341 Brás, por não ter exibido todos os documentos exigidos pela Portaria $n^{\circ}$ 09/2009-SP-MO/SMSP para o recadastramento dos permissionários que exercem atividades de comércio e prestação de serviços ambulantes na região administrativa da Subprefeitura da Móoca.

A sentença concedeu a segurança pleiteada anulando a cassação do termo de permissão de uso. Sob o entendimento de que, embora seja ato administrativo unilateral e precário, não poderia se dar de forma arbitrária e ofendendo os princípios da legalidade, moralidade, razoabilidade e proporcionalidade, motivação e impessoalidade, além do princípio do "due processo of law".

A municipalidade, por sua vez, aduziu que a permissão de uso se insere no âmbito da discricionariedade administrativa, que caberia unicamente à Administração 
Pública decidir acerca da outorga de permissão de uso de bens públicos, segundo seus critérios de oportunidade e conveniência, pois de competência exclusiva do Poder Executivo a gestão de seus bens; que o Poder Judiciário não pode assomar para si os atos discricionários que competem exclusivamente ao Poder Executivo, sob pena de ofensa ao princípio da separação dos poderes.

Em seu voto, a Relatora destacou o caráter precário das permissões, o que permitiria a sua revogação a qualquer tempo, de acordo com a conveniência, a oportunidade e o interesse público. Observou que foram garantidos os princípios do contraditório e da ampla defesa, já que a impetrante teve a oportunidade de interpor os recursos que entendeu cabíveis contra a decisão da autoridade coatora, bem como, destacou que a existência de inúmeros requerimentos de melhorias urbanísticas evidenciava a inconveniência e inoportunidade da manutenção de ambulantes no local, não havendo motivo para se falar em violação do devido processo legal.

Foi dado provimento ao recurso, por votação unânime. 


\section{Conclusão}

A primeira parte desta pesquisa procurou situar o tema da discricionariedade e do controle judicial dos atos administrativos de forma mais conceitual e histórica. A abordagem contida nessa primeira parte objetivou permitir um acompanhamento mais facilitado dos julgados, em face da anterior introdução aos temas.

A segunda parte procurou abordar o controle dos atos administrativos pelo Poder Judiciário, de forma prática, por meio da análise dos julgados que foram selecionados de cada um dos três Tribunais. A busca pelos acórdãos foi feita mediante consulta ao "site" dos próprios Tribunais, por meio de "palavras chave", à exceção de alguns poucos obtidos em consulta ao periódico "Revista de Direito Administrativo".

Para exemplificar, somente no "site" do Supremo Tribunal Federal, utilizando palavras-chave (atos discricionário, motivação, conveniência, oportunidade, revisão e atos administrativos, discricionariedade, discricionário, controle judicial, controle jurisdicional) em diferentes combinações, foram localizados mais de quinhentos e oitenta acórdãos, os quais foram "filtrados", restando os julgados que fazem parte desta pesquisa.

É bastante provável que mesmo com essa forma de pesquisa, acórdãos importantes não tenham sido localizados em decorrência de motivos diversos, especialmente a não adequação das palavras chave, e que, por isso, tenham deixado de fazer parte deste trabalho.

Esta pesquisa teve como objetivo verificar se é possível identificar uma mudança substancial nos limites do controle judicial dos atos administrativos discricionários, no período dos acórdãos selecionados, ou seja, por volta da segunda metade do século passado até os nossos dias.

Um dos acórdãos mais antigos analisados foi a apelação cível $\mathrm{n}^{\circ}$. 1.422, de 28/7/1948, relatada pelo Desembargador Seabra Fagundes. O Desembargador, com base na teoria do desvio de poder/finalidade impediu que a Administração Pública protegesse uma empresa de transporte, em detrimento de sua concorrente e das pessoas que se serviam do transporte público. 
O Tribunal anulou o ato do administrador e também autorizou o impetrante a fazer circular o seu coletivo no horário que havia pleiteado à Administração. Essa decisão foi bastante avançada para a época.

Esse Julgado serviu para mostrar que um controle baseado apenas em aspectos formais de legalidade, ou seja, competência e forma, não eram suficientes para coibir os abusos da Administração.

No caso dos Julgados do Supremo Tribunal Federal, o primeiro acórdão analisado foi o agravo de petição $\mathrm{n}^{\circ}$. 9.949, de 16/9/1941. Tratava-se de caso de aposentadoria concedida sem motivação, em decorrência de o Reclamante ter participado do movimento revolucionário de 1932. O Ministro José Linhares, Relator, assentou que não era lícito invocar garantias constitucionais num período anormal de governo e que não caberia ao Judiciário rever o ato praticado pela Administração.

No mesmo sentido é o caso do agravo de petição $\mathrm{n}^{\circ}$. 12.210 , de 28/5/1945, em que se analisou Reforma de Capitão Médico do Exército, com base no art. 177 da Constituição, o Ministro Castro Nunes, Relator, entendeu que o reformado pelo art. 177 "não pode pretender a revisão do ato sob o ponto de vista da conveniência ou oportunidade da medida, ainda que injusta".

O Ministro Orosimbo Nonato, na análise do recurso extraordinário nº 19.720 , de 17/6/1952, vislumbrou a possibilidade de freio ao ato discricionário invocando a teoria do desvio de poder e a teoria dos motivos determinantes, já que o ato deveria ter como base o apurado no processo administrativo e uma vez que esse processo não existia, o ato tinha como fundamento o nada. Da ementa consta que, "ao contrário do ato de império, o ato discricionário não escapa à apreciação funcional do Poder Judiciário".

Nos embargos no recurso extraordinário $n^{\circ}$. 21.541, de 25/06/1954, o Relator, Ministro Mario Guimarães, em seu voto, afirmou que a aposentadoria fora concedida em pleno período discricionário e, neste caso, o juiz da conveniência era o Presidente da República, que não precisava justificar seu ato. Embora fazendo menção à teoria dos motivos determinantes, entendeu que não se aplicava ao caso.

Nestes e nos demais casos relacionados a esse período histórico, com base nesses Julgados, o Tribunal apenas chancelou os atos da administração, muito embora, seja possível identificar o pipocar de ideias de vanguarda, consubstanciada no voto do 
Ministro Orosimbo Nonato, que ventilou a aplicação da teoria do desvio de poder e dos motivos determinantes. Interessante é que seu voto foi acompanhado pelos Ministros Lafayete de Andrada, Rocha Lagôa, Abner de Vasconcelos e Afranio Costa.

Como dito anteriormente, a inclusão desses julgados justifica-se mais pelo valor histórico, mas, também, para um confronto com a atualidade.

Especificamente em relação à exigência de motivação expressa, destaque-se no Supremo Tribunal Federal o Recurso Extraordinário nº 131.661, de 26/9/1995, no qual o Ministro Marco Aurélio assentou a necessidade da motivação nos atos administrativos discricionários.

Como anteriormente frisado, foi bastante nítida a mudança de entendimento verificada neste julgado, no que tange à necessidade de motivação, em relação ao MS 16.807, no qual a discricionariedade excluía a motivação e ao MS 20.021, no qual a motivação só seria necessária se houvesse previsão expressa em lei.

Em relação ao Superior Tribunal de Justiça, é possível destacar o acórdão $n^{\circ}$. 17.718, que deu também especial relevo à motivação dos atos administrativos. A ementa do acórdão deixou claro o entendimento dos Ministros, de que todos os atos administrativos são passíveis de controle jurisdicional (art. $5^{\circ} . \mathrm{XXXV}, \mathrm{CR} / 88$ ) e que esse controle, em especial nos atos discricionários, é feito por meio da motivação, como condição de sua própria validade.

Em relação ao Tribunal de Justiça de São Paulo, a decisão no Reexame necessário $n^{\circ}$. 0000700-04.2011.8.26.0159, de 22/1/2013, relatada pelo Ministro Gilson Dip, consigna que a motivação expressa, na esfera dos atos discricionários, vincula o agente público e, "dessa maneira, a exigível congruência do ato administrativo impõe a consonância entre a realidade subjacente, o conteúdo do ato e sua causa, tal que fins e motivos estejam em conformidade lógica, sem que se admita, além disso, no campo dos atos administrativos discricionários, o exercício de uma discricionariedade substituinte pelo Poder Judiciário".

A importância dos princípios da razoabilidade, da moralidade, da proporcionalidade na edição do ato administrativo discricionário fazem parte de inúmeros acórdãos. No caso do Superior Tribunal de Justiça é possível destacar o Recurso Especial no $n^{\circ}$ 575.280, de 11/11/2003, relatado pela Ministra Eliana Calmon, no 
qual ela afirma que "o Poder Judiciário não mais se limita a examinar os aspectos extrínsecos da administração, pois pode analisar, ainda, as razões de conveniência e oportunidade, uma vez que essas razões devem observar critérios de moralidade e razoabilidade".

No caso do TJSP é possível destacar a existência de inúmeros julgados, dentre eles, a apelação cível no 0016363-83.2012.8.26.0053, de 29/7/2013, no sentido de que os princípios da razoabilidade e da proporcionalidade possibilitam um controle mais efetivo da discricionariedade administrativa, evitando possíveis arbitrariedades, na atuação dos agentes estatais.

No caso das ações civis públicas que buscam a implantação de determinadas políticas públicas, há também inúmeros julgados, devendo ser citados: o Recurso Especial nº 63128 (STJ), de 20/5/1996, o qual entendeu haver intromissão indevida do Poder Judiciário no Executivo, único em condições de escolher o momento oportuno e conveniente para a execução da obra reclamada. O Recurso Especial $n^{\circ} .575 .280$, de 2/9/2004, da Relatoria do Ministro Luiz Fux, destacou que o atendimento em creche e pré-escola ás crianças de zero a seis anos de idade é dever do Estado e direito subjetivo da criança; portanto, para o Ministro, não seria correto alegar discricionariedade do administrador diante desses direitos consagrados constitucionalmente. Na verdade, para ele, trata-se de atividade vinculada, inadmitindo-se qualquer exegese que vise afastar a garantia pétrea.

No caso do TJSP, a apelação cível nº 990.10.4892400-6, de 8/2/2011, cuidou de recurso em ação civil pública. O Relator, Magalhães Coelho, assentou que "deixar de implementar políticas urbanísticas não é uma questão afeta à subjetividade do administrador; ainda que se reconheçam graus de liberdade em suas opções, não poderia o administrador furtar-se a cumprir e concretizar políticas públicas erigidas pela Constituição Federal, como na hipótese da saúde pública, em direito subjetivo individual e coletivo da cidadania".

É possível verificar que tanto as ações individuais, quanto as ações civis públicas que digam respeito à implantação de políticas públicas na área da saúde, meio ambiente e de proteção às crianças e adolescentes, têm sido providas nos Tribunais. 
Quanto à possibilidade de apreciação do mérito do ato administrativo pelo Judiciário, alguns acórdãos podem ser destacados. No STF o mandado de segurança $\mathrm{n}^{\circ}$. 20.999-2, de 21/3/1990. A escolha desse julgado justifica-se pelas colocações precisas do Ministro Celso de Mello acerca do exercício do controle pelo Poder Judiciário, especialmente o contido na ementa, a qual pondera que

É preciso evoluir, cada vez mais, no sentido da completa justiciabilidade da atividade estatal e fortalecer o postulado da inafastabilidade de toda e qualquer fiscalização judicial. A progressiva redução e eliminação dos círculos de imunidade do poder há de gerar, como expressivo efeito consequencial, a interdição de seu exercício abusivo.

Acerca do controle punitivo dos atos disciplinares, sublinha o Ministro que os Juízes e Tribunais "só não podem examinar a conveniência, a utilidade, a oportunidade e a necessidade da punição disciplinar (RTJ 100/1381)"; portanto, o mérito do ato. Segundo ele, o que, porém, não siginifica a impossibilidade de o Judiciário verificar se existe, ou não, causa legítima que autorize a imposição de sanção disciplinar. Para ele, com essa ressalva, a sindicabilidade judicial sobre os atos disciplinares é ampla

No STJ, é possível destacar o julgamento do Recurso Especial nº 429.570 , de 11/11/2003, relatado pela Ministra Eliana Calmon, em que ficou assentado que "o Poder Judiciário não mais se limita a examinar os aspectos extrínsecos da administração, pois pode analisar, ainda, as razões de conveniência e oportunidade, uma vez que essas razões devem observar critérios de moralidade e razoabilidade." A tendência, portanto, é a de manter fiscalizado o espaço livre de entendimento da Administração, espaço este gerado pela discricionariedade.

Por sua vez, ao analisar o recurso nº 37.964 , de 20/10/2012, a Ministra Eliana Calmon, diferentemente, do que estabeleceu o acórdão no.429.570, explicitou que "não cabe ao Poder Judiciário adentrar no mérito do ato administrativo para rever o juízo de conveniência e oportunidade da autoridade tida como coatora, ressalvando os casos de ilegalidade, defeito de forma, abuso de autoridade ou teratologia.

Com relação ao TJSP, destaca-se a apelação cível nº 0041683 09.2010.8.26.0053, de 30/1/2013, em que a Desembargadora Maria Cristina Cotofre assentou que a apreciação dos atos administrativos pelo Poder Judiciário é admitida em 
qualquer hipótese, de modo que inexiste óbice para que se analisem os motivos da reprovação contra os quais se insurgiu o apelante. (...), "cabe ao Judiciário analisar e reprimir ilegalidades cometidas pelo administrador, não havendo que se falar em intromissão na discricionariedade do mérito do ato".

$\mathrm{Na}$ análise dos acórdãos relacionados ao servidor público, o mandado de segurança $n^{\circ}$. 1.103, de 1/12/1949, trata de transferência compulsória para a reserva remunerada. O Ministro Orosimbo Nonato posicionou-se apontando abuso, pois no seu entendimento teria sido violado o princípio da inafastabilidade do controle judicial, já que o "Conselho de Almirantes" teria o poder de decidir em definitivo os recursos que lhe fossem opostos. O Ministro Ribeiro da Costa também foi voto vencido.

No caso dos embargos na apelação cível $n^{\circ}$. 7.307, de 20/12/1944, o autor propôs ação para anular ato de sua demissão e a controvérsia que se instalou foi bastante interessante para a época: qual seria o limite que o Judiciário deveria observar ao julgar as demissões de funcionários. Poderia examinar os motivos que serviram de base para o ato, ou ficaria adstrito apenas aos aspectos formais?

O Relator, Ministro José Linhares, apoiado pelo ministro Bento de Faria, expôs entendimento no sentido de que o exame da legalidade se circunscreve aos aspectos formais do ato. Orosimbo Nonato e Goulart de Oliveira, concluiram que a ação reparadora dos tribunais não se confinaria em limites tão estreitos. Entendeu Orosimbo Nonato que não devia o Poder Judiciário limitar-se a apreciar o ato administrativo do ângulo de legalidade extrínseca e sim de seu mérito intrínseco, ou seja, de sua justiça ou injustiça.

Verifica-se, conforme comentários de Vitor Nunes Leal ao acórdão, que houve um rompimento de orientação do Supremo, no sentido de limitar a indagação judicial às questões de competência e aos aspectos formais do inquérito, para o entendimento de que cabe ao Judiciário reexaminar as provas do inquérito, que contemplarão os motivos a serem considerados na demissão, para, inclusive, contrapor-lhes novas provas produzidas em juízo.

No acórdão nº 7.320, de 21/6/1960, o Ministro Lafayette Andrada, Relator, chegou a afirmar que a discrição administrativa consistiria na possibilidade de se praticarem atos baseados em considerações não interiamente suscetíveis de prova. Tal 
ponderação conduzia ao entendimento de que os motivos do ato seriam insuscetíveis de exame pelo Judiciário. Assentou o Relator que "os motivos do ato, em tal caso, são referidos à discrição dos trabalhadore públicos, não cabendo o seu exame, nesta parte, ao poder incumbido de aplicação do direito".

Pela análise desses Julgados foi possível identificar um desbordamento de aspectos antes considerados como passíveis de controle judicial dos atos discricionários, assim como, um alargamento do princípio da legalidade ${ }^{202}$, para abranger também a motivação e a finalidade do ato. Foi ainda possível identificar uma maior incidência de controle exercido com base em princípios como a moralidade e a razoabilidade ${ }^{203}$, dentre outros.

Não obstante alguns julgados continuem a mencionar o não cabimento do controle sobre os aspectos de conveniência e oportunidade do ato, essa ideia de um núcleo de discricionariedade, insuscetível de controle judicial, quer à luz da legalidade, quer à luz dos princípios de Direito, não mais pode subsistir em confronto com o inciso XXXV, artigo $5^{\circ}$. da Constituição de 1988.

\footnotetext{
${ }^{202}$ APELAÇÃO nº 0034542-02.2011.8.26.0053, SÃO PAULO - OITAVA CÂMARA DE DIREITO PÚBLICO RELATOR: PAULO DIMAS MASCARETTI - JULGAMENTO: 8/5/2013. no controle de legalidade incumbe ao Judiciário a verificação dos antecedentes de fato e sua congruência com as justificativas que determinaram a decisão administrativa, ou seja, o exame dos motivos que a ensejaram. A ausência de nexo entre a realidade demonstrada e os fundamentos jurídicos da atuação pública caracterizam o vício de ilegalidade e a consequente nulidade do ato administrativo".

${ }^{203}$ Para ele, toda disciplina punitiva deve subordinar-se ao princípio da proporcionalidade em sentido amplo, no qual se contém a razoabilidade, impondo-se então a equivalência entre a realidade fática e a cominação imposta no edital do concurso.
} 


\section{REFERÊNCIAS}

ADAMI, Mateus Piva; orientador: Floriano de Azevedo Marques Neto. A Discricionariedade Administrativa em Face do Princípio da Eficiência. São Paulo: 2007.

ALESSI, Renato. Sistema Istituzionale del Diritto Amministrativo Italiano. 3. ed. Milano: A. Giuffrè, 1960.

. Principi di diritto amministrativo. E. ed. Milano: A. Giuffrè, 1974.

ALMEIDA, Fernando Dias Menezes de. Memória Jurisprudencial: Ministro Victor Nunes. Brasília: Supremo Tribunal Federal, 2006.

ALVES JÚNIOR, Luís Carlos Martins. Memória Jurisprudencial: Ministro Evandro Lins. Brasília: Supremo Tribunal Federal, 2009.

AMARAL, Antônio Carlos Cintra do. Extinção do Ato Administrativo. São Paulo: Editora Revista dos Tribunais, 1978.

ARAGÃO, Alexandre Santos de (coord.). O Poder Normativo das Agências Reguladoras. $2^{\text {a }}$. ed., Rio de Janeiro: Forense, 2011.

, MARQUES NETO, Floriano de Azevedo (coord.). Direito Administrativo e seus novos paradigmas. Belo Horizonte: Editora Fórum, 2008.

ARAÚJO, Edmir Netto de. Curso de Direito Administrativo. 4. ed. rev. e atual. São Paulo: Saraiva, 2009.

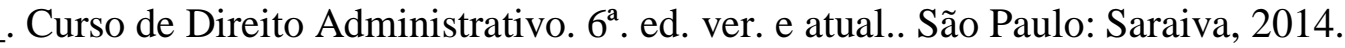

. Do Negócio Jurídico Administrativo. São Paulo: Editora Revista dos Tribunais, 1992.

. O Ilícito Administrativo e seu processo.. São Paulo: Editora Revista dos Tribunais, 1994.

. Responsabilidade do Estado por Ato Jurisdicional. São Paulo: Editora Revista dos Tribunais, 1981

ARRUDA ALVIM, José Manuel de. A discricionariedade administrativa e o controle judicial. In: SUNDEFELD, Carlos Ari; BUENO, Cássio Scarpinella (Coord.) Direito Processual Público - a fazenda pública em juízo. São Paulo: Malheiros, 2000.

ARRUDA, José Robson de A.. Toda a História. São Paulo: Ática, 1994.

História Moderna e Contemporânea. São Paulo: Ática, 1978.

BACHOF, Otto; WOLF, Hans J.; STOBER, Rolf. Direito Administrativo, (Tradução: SOUSA, antónio F. de), vol. 1. Fundação Caloustem Gulbenkian, 1999. 
BACIGALUPO, Mariano. La discrecionalidad Administrativa: Estrutuctura normative, control judicial y limites constitucionales de su atribución. Madrid: Marcial Pons, Ediciones Jurídicas y Sociales, S.A., 1997.

BANDEIRA DE MELLO, Celso Antônio. Curso de direito administrativo. 8. ed., São Paulo: Malheiros, 1996.

. Curso de direito administrativo. 27 . ed., São Paulo: Malheiros, 2010.

. Discricionariedade e controle jurisdicional. 2. ed., São Paulo: Malheiros, 1996.

- Legalidade - Discricionariedade - Seus Limites e Controle, in Revista de Direito Público, São Paulo, RT, nº 86, ano XXI, p. 42-59, abr./jun. 1988.

. Grandes Temas de Direito Administrativo. $1^{\mathrm{a}}$ ed., $2^{\mathrm{a}}$ tiragem, São Paulo: Malheiros, 06.2010.

BANDEIRA DE MELLO. Oswaldo Aranha. Princípios gerais do direito administrativo. Rio de Janeiro: Forense, 1979.

BARROSO, Luís Roberto. Os Princípios da Razoabilidade e da Proporcionalidade no Direito Constitucional, in Cadernos de Direito Constitucional e Ciência Política, São Paulo, RT, v. 23, p.65-78, abr./jul.1998.

BASTOS, Celso Ribeiro. Curso de Direito Administrativo. São Paulo: Celso Bastos Editora, 2002.

BASTOS, Celso Ribeiro e MARTINS, Ives Gandra. Comentários à Constituição do Brasil: promulgada em 5 de outubro de 1988. São Paulo: Saraiva, 1991.

BIELSA, Rafael. Principios de Derecho Administrativo. Buenos Aires: Universidad Universal Del Litoral, 1942.

BINENBOJM, Gustavo. Uma Teoria do Direito Administrativo: direitos fundamentais, democracia e constitucionalização. $2^{\mathrm{a}}$. ed. Revista e atualizada, Rio de Janeiro: Renovar, 2008 .

BOBBIO, Norberto. A Era dos Direitos. Tradução de Carlos Nelson Coutinho. $7^{\mathrm{a}}$. reimpressão. Rio de Janeiro: Elsevier, 2004.

, MATTEUCCI, Nicola e PASQUINO, Gianfranco. Dicionário de política. Tradução de Carmen C. Varriale et. al. 12. ed., Brasília: Editora Universidade de Brasília, São Paulo: Imprensa Oficial do Estado, 2002, v. 1-2. Título original: Dizionario di politica.

BONAVIDES, Paulo. Curso de Direito Constitucional. 15. ed., São Paulo: Malheiros Editores, 2004.

BONFIM, Edílson Mougenot. Direito Administrativo. São Paulo: Saraiva, 2005. 
BUCCI, Maria Paula Dallari. Direito administrativo e políticas públicas. São Paulo: Saraiva, 2002.

CAETANO, Marcello. Manual de Direito Administrativo, Tomo I. 10a . ed. (Revista e atualizada pelo Prof. Doutor Diogo Freitas do Amaral). Lisboa: Coimbra Editora, 1973.

CAMPAZ, Walter. Revogação dos Atos Administrativos. São Paulo: Ed. Revista dos Tribunais, 1983.

CARNELUTTI, Francesco (Tradução: BRUNO, Francisco José Galvão). Discurso sobre o Direito. Leme/SP: Habermann Editora, 2009.

CARVALHO FILHO, José dos Santos. Manual de Direito Administrativo. 10a . ed. Rio de Janeiro: Lúmen Juris, 2003.

Manual de Direito Administrativo. 24a . ed. Rio de Janeiro: Lumen Juris, 2011

CASSAGNE, Juan Carlos. Derecho Administrativo. 4. ed. Atual. Buenos Aires: AbeledoPerrot, 1993. Tomo I e II.

El Acto Administrativo. Buenos Aires: Abeledo-Perrot, 1994.

El Principio De Legalidad Y El Control Judicial De La Discrecionalidad Administrativa. $1^{a}$ ed.. Buenos Aires: Marcial Pons Argentina, 2009.

CAVALCANTE, Themístocles Brandão. A teoria do silêncio no direito administrativo. Revista Forense. Rio de Janeiro, v. 77, ano 36, 1939.

. Curso de Direito Administrativo. 4a . ed., São Paulo: Livraria Freitas Bastos S.A., 1956.

Do Poder Discricionário, in Revista de Direito Administrativo - Seleção Histórica, Rio de Janeiro, FGV, Renovar, p. 431-451,1991.

CINTRA, Antonio Carlos de Araújo. Motivo e motivação do ato administrativo. São Paulo: Editora Revista dos Tribunais, 1979.

CINTRA, Antonio Carlos de Araújo. Controle dos Atos Administrativos Quanto aos Motivos e à Motivação, in Motivo e Motivação do Ato Administrativo, São Paulo, RT, p.155-184, 1979.

DEBBASCH, Charles; COLIN, Frédéric. Droit Administratif. 9a . Ed.Paris: Économica, 2010 .

COSTA, Regina Helena. Conceitos Jurídicos Indeterminados e Discricionariedade Administrativa, in Revista da Procuradoria Geral do Estado, volume 29, p.79-105, jun. 1988. 
CRETELLA JÚNIOR, José. Controle Jurisdicional do Ato Administrativo. $3^{\mathrm{a}}$. Ed.. Rio de Janeiro: Forense, 1993.

Direito Administrativo Comparado. $1^{\text {a }}$. ed., São Paulo: Editora Universidade de São Paulo, 1972.

Direito Administrativo Comparado. $1^{\text {a }}$. ed., São Paulo: Editora Universidade de São Paulo, 1972.

- Ato Administrativo - A Tridimensão da discricionariedade, in Revista de Direito Administrativo, Rio de Janeiro - FGV, vol. 119, p. 33 a 39, jan./mar. 1975.

Direito Administrativo Brasileiro. Rio de Janeiro: Forense, 1999.

D’ALESSIO, Francesco. Istituzioni Di Diritto Amministrativo Italiano. Torino: Unione Tipografico - Editrice Torinense, 1943.

DALLARI, Dalmo de Abreu Dallari. Elementos de teoria geral do Estado. 28. ed. São Paulo: Saraiva, 2009.

DI PIETRO, Maria Sylvia Zanella. Direito administrativo. 23a ., São Paulo: Atlas, 2010.

Discricionariedade Administrativa na Constituição de 1988. 2a. ed., São Paulo: Atlas, 2007.

- Discricionariedade Administrativa na Constituição de 1988. $3^{\text {a }}$. ed., São Paulo: Atlas, 2012.

RIBEIRO, Carlos vinícius Alves (Coord). Supremacia do Interesse Público. São Paulo: Atlas, 2010.

- MARQUES NETO, Floriano Azevedo. Discricionariedade Administrativa e Controle Judicial da Administração, in Processo Civil e Interesse Público, (Carlos Alberto De Salles - org.), São Paulo: RT, 2003.

DINIZ, Maria Helena. Compêndio de Introdução à Ciência do Direito. 7. ed., atual. São Paulo: Saraiva, 1995.

DUGUIT, Léon. Les Transformations du Droit Public. Paris: Armand Colin, 1913.

ENTERRIA, Eduardo Garcia de. Principi di Diritto Administrativo. 8. ed. São Paulo: Atlas, 1997.

.Tradução de Fábio Medina Osório. As Transformações da Justiça Administrativa Da Sindicalidade Restrita à Plenitude Jurisdicional. Uma Mudança de Paradigma? Belo Horizonte: Editora Fórum, 2010.

ESCOLA, Héctor Jorge. Compendio de Derecho Administrativo, v.II. Buenos Aires: Ediciones Depalma, 1990. 
FERNÁNDES, Tomás Ramon. Corso de Derecho administrativo. Madri: Editora Civitas, 1983.

FAGUNDES, M. Seabra. O controle dos atos administrativos pelo Poder Judiciário. $4^{\mathrm{a}}$. Ed. atualizada, Rio de Janeiro: Forense, 1967.

. Conceito de Mérito no Direito Administrativo, in Revista de Direito Administrativo, Rio de Janeiro, FGV, v. 23, p.1-16, jan./mar.1951.

- O controle dos atos administrativos pelo Poder Judiciário (atualizado por BINENbOJM. . 8. ed. atual. por Gustavo Binenbojm, Rio de Janeiro: Forense, 2005.

FARIA, Edimur Ferreira de. Controle do Mérito do Ato Administrativo pelo Judiciário. Belo Horizonte: Editora Fórum, 2011.

FERRAZ JR, Tércio Sampaio. Introdução ao Estudo do Direito. 2. ed. São Paulo: Atlas, 1994.

FERREIRA FILHO, Manoel Gonçalves. Comentários à Constituição brasileira de 1988. .Curso de Direito Constitucional. 33 ${ }^{\text {a }}$ ed.rev. e atual., São Paulo: Saraiva, 2007.

FERREIRA, Pinto. Comentários à Constituição brasileira. São Paulo: Saraiva, 1992.

FIGUEIREDO, Lucia Valle. Curso de Direito Administrativo. $5^{\mathrm{a}}$ ed. São Paulo: Malheiros, 2001 . . Controle da Administração Pública. São Paulo: Revista dos Tribunais, 1991.

FORSTER, Nestor José. O silêncio no negócio jurídico. Revista de Jurisprudência do Tribunal do rio Grande do Sul, Porto Alegre, ano V, n. 21, 1970.

FRAGA, Gabino. Derecho Administrativo. Duodecima edicion. Mexico: Editorial Porrua, 1968.

FREITAS, Juarez. $O$ controle dos atos administrativos e os princípios fundamentais. 3. ed. rev. e ampl., São Paulo: Malheiros, 2004.

$O$ controle dos atos administrativos e os princípios fundamentais. $2^{\text {a }}$.ed.., São Paulo: Malheiros, 1999.

$O$ controle dos atos administrativos e os princípios fundamentais. $4^{\text {a }}$.ed.., São Paulo: Malheiros, 04.2009

2004.

A interpretação sistemática do direito. 4. ed., São Paulo: Malheiros Editores,

- Discricionariedade Administrativa e o Direito Fundamental à Boa Administração Pública. 2a . Ed., São Paulo: Malheiros, 2009. 
FUCK, Luciano Felício. Memória Jurisprudencial: Ministro Nelson Hungria. Brasília: Supremo Tribunal Federal, 2012.

GARCIA, Emerson (coord.). Discricionariedade Administrativa. Rio de Janeiro: Lumen Juris, 2005.

GASPARINI, Diógenes. Direito Administrativo. 4. ed. rev. e ampl. São Paulo: Saraiva, 1995.

GOYARD, Claude. État de Droit et Démocratie. In: Melangés René Chapus. Droit Administratif.Paris: Montchrestien, 1992.

GONÇALVES, Aroldo Plínio. Poder Judiciário. In: TEIXEIRA, Sálvio de Figueiredo. O Judiciário e a Constituição. São Paulo: Saraiva, 1994.

GORDILLO, Augustín. El acto administrativo. 2. ed. Buenos Aires:Abeledo-Perrot, 1969.

Tratado de Derecho Administrativo. Tomo 3 El Acto Administrativo. 5a . ed.Buenos Aires: Fundación de Derecho Administrativo, 2000.

GRAU, Eros Roberto e CUNHA, Sérgio Sérvulo da (coords.). Estudos de direito constitucional em homenagem a José Afonso da Silva. São Paulo: Malheiros Editores.

GRAU, Eros Roberto e GUERRA FILHO, Willis Santiago (coords.). Direito Constitucional: estudos em homenagem a Paulo Bonavides. São Paulo: Malheiros Editores, 2003.

. Direito, Conceitos e Normas Jurídicas (p. 55-84). São Paulo: RT, 1988.

O direito posto e o direito pressuposto. $8^{\text {a }}$. ed. São Paulo: Malheiros, 08.2011.

GROTTI, Dinorá Adelaide Musetti. O Desvio de Poder em Atos Administrativos. In: MARQUES NETO, Floriano de Azevedo Marques et al (organizadores). Direito e Administração Pública. Estudos em homenagem a Maria Sylvia Zanella Di Pietro. São Paulo: Editora Atlas, 2013.

O Serviço Público e a Constituição Brasileira de 1988.São Paulo: Malheiros, 2003.

GUERRA, Sérgio. Discricionariedade dos Atos das Agências Regulatórias, in Controle Judicial dos Atos Regulatórios, Rio de Janeiro: Lúmen Júris, 2005.

Discricionariedade administrativa - Limitações da vinculação legalitária e propostas pós-positivistas. In: ARAGÃ̃, Alexandre Santos de; MARQUES NETO, Floriano de Azevedo (Coordenadores). Direito Administrativo e seus novos paradigmas. Belo Horizonte: Fórum, 2008.

GUSMÃO, Paulo Dourado de. Introdução ao Estudo do Direito. 17. ed. Rio de Janeiro: Forense, 1995.

HORBACH, Carlos Bastide. Teoria das nulidades do ato administrativo. $2^{\text {a }}$. ed. São Paulo: Editora Revista dos Tribunais, 2010. 
Memória Jurisprudencial: Ministro Pedro Lessa. Brasília: Supremo Tribunal Federal, 2007.

IRELLI, Vincenzo Cerulli. Corso Di Diritto Ammistrativo. Torino: G. Giappichelli Editore, 2000 .

JUSTEN FILHO, Marçal. Comentários à Lei de Licitações e Contratos Administrativos. 11. ed.São Paulo: Dialética, 2005.

Curso de direito administrativo. São Paulo: Saraiva, 2005.

- Curso de direito administrativo. 8. Ed., Belo Horizonte: Fórum, 2012.

KELSEN, Hans. Teoria geral do direito e do estado. Tradução de Luís Carlos Borges. 3. ed., São Paulo: Martins Fontes, 1998. Título original: General Theory of Law and State.

LEAL, Roger Stiefelmann. Memória Jurisprudencial: Ministro Orozimbo Nonato. Brasília: Supremo Tribunal Federal, 2007.

LEAL, Vítor Nunes. Delegações Legislativas, in Revista de Direito Administrativo, Rio de Janeiro, FGV , volume V, p. 378-391, jul.1946.

. Lei e Regulamento, in Revista de Direito Administrativo 1, Rio de Janeiro, FGV, p. 371-399, jan.1945.

LOPES, Marcelo Netto de Moura. Controle Jurisdicional dos Atos discricionários da Administração Pública. Prof. Paulo Afonso Cavichioli Carmona (orientador). Brasília (DF), FESMPDFT, 2009.

- Reconsideração do Tema do Abuso de Poder, in Revista de Direito Administrativo - Seleção Histórica, Rio de Janeiro, FGV, Renovar, p.453-467, 1991.

- Os Atos Administrativos Perante o Poder Judiciário, in Problemas de Direito Público. Rio de Janeiro: Forense , $1^{\text {a }}$ edição, p. 256-294, 1960.

LOPES, José Reinaldo de Lima; QUEIROZ, Rafael Mafei Rabelo; ACCA, Thiago dos Santos. Curso de História do Direito.São Paulo: Método, 2006.

LOSANO, Mario G. Sistema e estrutura no direito. Tradução Carlos Alberto Dastoli. São Paulo: Martins Fontes, 2008.

LOUBET, Wilson Vieira. O Princípio da Indisponibilidade do interesse Público e a Administração Consensual. Brasília - DF: Editora Consulex, 2009.

MARINONI, Luiz Guilherme. Art. 50 - XXXV - Direito Fundamental de Ação. In: CANOTILHO, José Joaquim Gomes. Comentários à Constituição do Brasil. São Paulo: Saraiva/Almedina, 2013.

MARQUES NETO, Floriano Peixoto de Azevedo. Regulação Estatal e Interesses Públicos. São Paulo: Malheiros Editores, 04-2002. 
. Os grandes desafios do controle da Administração Pública. In: MODESTO, Paulo (coord.). Nova Organização Administrativa Brasileira. Belo Horizonte: Editora Fórum, 2010 .

MARTINS JR., Wallace Paiva. Transparência administrativa: publicidade, motivação e participação popular. São Paulo: Saraiva, 2004.

MEDAUAR, Odete. Direito Administrativo Moderno. São Paulo: Editora Revista dos Tribunais, 1996.

. O direito administrativo em evolução. 2. ed. rev. atual. e ampl., São Paulo: Editora Revista dos Tribunais, 2003.

. Controle da Administração Pública. 2a . Ed., revista, atualizada e ampliada. $2^{a}$. edição, São Paulo: Revista dos Tribunais, 2012.

, SCHIRATO, Vitor Rhein. (coord.). São Paulo: Editora Revista dos Tribunais, 2010 .

MEYER-PFLUG, Samantha Ribeiro. Memória Jurisprudencial: Ministro Castro Nunes. Brasília: Supremo Tribunal Federal, 2007.

MEIRELLES, Hely Lopes. Direito administrativo brasileiro. 35. ed. atual. por Eurico de Andrade Azevedo, Délcio Balestero Aleixo e José Emmanuel Burle Filho, São Paulo: Malheiros Editores, 2009.

- Os Poderes do Administrador Público, in Revista de Direito Administrativo Seleção Histórica, Rio de Janeiro, FGV, Renovar, p.327-343, 1991.

MERKL, Adolfo. Teoria General del Derecho Administrativo. Granada: Editoria Comares, 2004.

MIGLINO, Arnaldo. A Cor da Democracia. Florianópolis: Conceito Editorial, 2010.

MIRANDA, Henrique Savonitti. Curso de Direito Constitucional. $5^{\text {a }}$ ed. Ver. e amp. e atual. Brasília: distrito Federal, 2007.

2007.

. Curso de Direito Administrativo. 5 $5^{\text {a }}$ ed. Ver. E atual. Brasília: Senado Federal,

MIRANDA, Jorge. Teoria do Estado e da Constituição. Rio de Janeiro: Forense, 2005.

MONTORO, André Franco. Introdução à Ciência do Direito. 23. ed. São Paulo: Editora Revista dos Tribunais, 1995.

MORAES, Alexandre. Direito Constitucional. 22ª ed., São Paulo: Atlas, 2007.

MORAES, Germana de Oliveira. Controle Jurisdicional da Administração Pública. São Paulo: Dialética, 1999. 
MOREIRA NETO, Diogo de Figueiredo. Curso de direito administrativo: parte introdutória, Parte Geral e Parte Especial. 7ª . ed., Rio de Janeiro: Editora Forense, 1989.

- Legitimidade e Discricionariedade - Novas Reflexões sobre os Limites e Controle da Discricionariedade. Rio de Janeiro: Forense, 1989.

Legitimidade e /discricionariedade - Novas Reflexões sobre os limites e controle da discricionariedade. $2^{\mathrm{a}}$ ed. Rio de Janeiro: Forense, 1991.

MORÓN, Miguel Sánchez. Discrecionalidad administrativa y control judicial. Madrid: Editorial Tecnos, 1995.

MÜLLER, Friedrich. Teoria Estruturante do Direito. 2. ed. Ver., atual. e ampl. Tradução Peter Naumann, Eurides Avance de Souza. São Paulo: Editora Revista dos Tribunais, 2009.

NOHARA, Irene Patrícia. Limites à Razoabilidade nos Atos Administrativos. São Paulo: Atlas, 2006.

OLIVEIRA, Rafael Carvalho Rezende. A constitucionalização do Direito Administrativo. Rio de Janeiro: Lumen Juris, 2009.

OLIVEIRA, Regis Fernandes de. Regime Constitucional do Direito Financeiro. In: TÔRRES, Heleno Taveira (coord.). Tratado de direito constitucional tributário: estudos em homenagem a Paulo de Barros Carvalho. São Paulo: Saraiva, p. 467-496, 2005.

Ato Administrativo. 4. ed. rev., atual. e ampl., São Paulo: Editora Revista dos Tribunais, 2001.

PEREIRA, André Gonçalves. Erro e Ilegalidade no Acto Administrativo. Lisboa: Ática Editora, 1962.

PERSICO, Federico. Principii di DrittoAmministrativo. V. secondo. $4^{\text {a }}$. ed. Napoli: Riccardo Marghieri di Gius, 1890.

PIRES, Luis Manuel Fonseca. Controle Judicial da Discricionariedade Administrativa: dos conceitos jurídicos indeterminados às políticas públicas. Rio de Janeiro: Elsevier, 2009.

RAMOS, Elival da Silva. Ativismo Judicial - Parâmetros dogmáticos. $1^{\mathrm{a}}$. edição, São Paulo: $1^{a}$ ed., Saraiva, 2010.

POLTRONIERI, Renato. Discrionariedade dos Atos Administrativos e a Ambigüidade da Norma Jurídica Positiva. São Paulo: Editora Juarez de Oliveira, 2002.

QUEIRÓ, Afonso Rodrigues. A Teoria do "Desvio de Poder" em Direito Administrativo, in Revista de Direito Administrativo, Rio de Janeiro, FGV, volume VII, , p.52-80, jan./ mar.1947.

QUEIRÓ, Afonso Rodrigues. A Teoria do "Desvio de Poder" em Direito Administrativo, in Revista de Direito Administrativo, Rio de Janeiro, FGV, volume VI, p. 41-78, out.1946. 
RAMOS, Elival da Silva. Ativismo Judicial - Parâmetros Dogmáticos. 1 ${ }^{\text {a }}$. ed. São Paulo: Saraiva, 2010.

REALE, Miguel. Lições Preliminares de Direito. 22. ed.São Paulo: Saraiva, 1995. .Questões de direito público. São Paulo: Saraiva, 1997.

RÉGNIER, João Roberto Santos. Discricionariedade Administrativa. São Paulo: Malheiros, 1997.

Revista de Direito Administrativo. Rio de Janeiro, v. III, janeiro-1946, p. 69-98.

Revista de Direito Administrativo. Rio de Janeiro, v. 35, janeiro-março1954, p. 152-166.

Revista de Direito Administrativo. Rio de Janeiro, v. 22, outubro-dezembro-1950, p.192193.

RIBEIRO, Maria Teresa de Melo. O princípio da imparcialidade da administração pública. Coimbra: Almedina, 1996.

RIVERO, Jean; tradução J. Cretella Jr. Curso de Direito Administrativo Comparado. $2^{\mathrm{a}}$ ed. São Paulo: Editora Revista dos Tribunais, 2004.

SANTOS, Rogério Dutra dos. A Institucionalização da Dogmática Jurídico-Danônica Medieval. In: WOLKMER, Antonio Carlos (organizador). Fundamentos de História do Direito, $4^{\mathrm{a}}$. edição 2. Tiragem. Belo Horizonte: Del Rey, 2008.

SCHERZBERG, Arno (Tradução de Kelly Susane Alflen da). Para onde e de que forma vai o Direito Público? (Wozu und wie überhaupt noch öffentliches Recht?). Porto Alegre: Sergio Antonio Fabris Editor, 2006.

SEABRA FAGUNDES, Miguel. O controle dos atos administrativos pelo Poder Judiciário. 6. ed. atualiz. São Paulo: Saraiva, 1994.

. O controle dos atos administrativos pelo Poder Judiciário. $8^{\mathrm{a}}$. ed.. atualizador Gustavo Binenbojm. Rio de Janeiro: Forense, 2010.

SGARBOSSA, Luís Fernando. Crítica à Teoria dos Custos dos Direitos, vol. I, - Reserva do Possível.Porto alegre: Sergio Antonio Frabris Editor, 2010.

SILVA, José Afonso da. Curso de direito constitucional positivo. $2^{\mathrm{a}}$. ed. rev. e atual., São Paulo: Malheiros, 1996.

Curso de direito constitucional positivo. $20^{\mathrm{a}}$. ed. rev. e atual., São Paulo: Malheiros, 01.2002 .

SILVA, Luís Virgílio Afonso da. O Proporcional e o Razoável, in Revista dos Tribunais, v. 798, p.23-50, abr. 2002.

SILVA, Vasco Manoel Páscoa Dias Pereira da. Em Busca do Acto Administrativo Perdido. Coimbra: Almedina, 2003. 
SOUSA, António Francisco de. A Discricionariedade Administrativa. Lisboa: Editora Danubio, 1987.

SOUZA, Marina de Santana. A Permeabilidade das Questões de Mérito na Revisão judicial dos Atos Administrativos Discricionários relativos ao IOF, II e IPI na Jurisprudência do STF. Orientador: Prof. Fabrício Antônio Cardim de Almeida. Sbdp - Escola de Formação, São Paulo, 2007.

SOUZA, Osvaldo Rodrigues de. História Geral - Da pré-história aos últimos fatos de nossos dias. São Paulo: Ática, 1979.

SOUZA, Rodrigo Pagani. A Jurisprudência do Supremo Tribunal Federal no Controle da Administração pública: uma releitura do controle dos atos administrativos discricionários. Orientador: Profa. Andressa Lin Fidelis. Sbdp - Escola de Formação, 2009.

SPITZCOVSKY, Celso. Direito Administrativo. 8ª ed. São Paulo: Damásio de Jesus, 2006.

SUNDFELD, Carlos Ari (coord.). Direito administrativo econômico. São Paulo: Malheiros Editores, 2002.

. Direito Administrativo Ordenador. São Paulo: Malheiros, $1^{\text {a }}$ ed., 2003.

TÁCITO, Caio. Poder Vinculado e Poder Discricionário, in Temas de Direito Público (Estudos e Pareceres), Rio de Janeiro, $1^{\circ}$ volume, Renovar, p. 315-336, 1997.

- As Delegações Legislativas e o Poder Regulamentar, in Revista de Direito

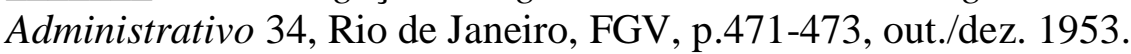

TOURINHO, Rita. A Discricionariedade Administrativa perante os Conceitos Jurídicos Indeterminados, in Revista de Direito Administrativo, Rio de Janeiro, v.237 2004.

VALADÃO, Marcos Aurélio Pereira. Memória Jurisprudencial: Ministro Hahnemann Guimarães. Brasília: Supremo Tribunal Federal, 2010.

VALLE, Vanice Regina Lírio do. Audiências Públicas e Ativismo: Diálogo Social no STF, Belo Horizonte: Fórum, 2012.

VEDEL, Georges; DELVOLVÉ, Pierre. Droit Administratif. V.2. Paris: Presses Universitaires de France, 1984.

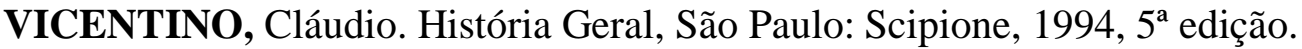

WALINE, Marcel. Traité Élémentaire de Droit Administratif, 5a . éd.Paris: Recueil Sirey, 1921.

www.stf.jus.br

www.stj.jus.br

www.tjsp.jus.br 
www.planalto.gov.br/ccivil_03/revista/Rev_35/panteao.htm

ZANCANER, Weida. Da convalidação e da invalidação do ato administrativo. 2. ed. 1. tiragem. São Paulo: Malheiros, 1993.

ZANOBINI, Guido. Corso di diritto amministrativo. 8. ed. Milano: Dotti A. Giuffrè, 1958.

ZIPPELIUS, Reinhold. Teoria Geral do Estado. 3. ed. Tradução de Karin Praefke-Aires Coutinho. Lisboa: Fundação Calouste Gulbenkian, 1997. Título original: Allgemeine Staatslehre.

ZYMLER, Benjamim. Direito administrativo e controle. Belo Horizonte: Fórum, 2005. 